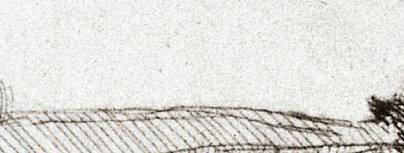

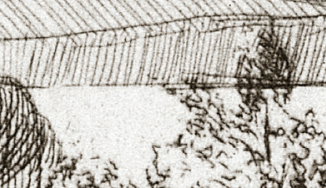

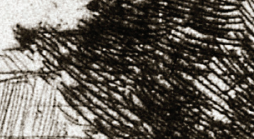
$+1$ , (3)

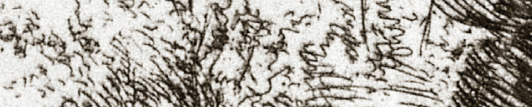
(1)

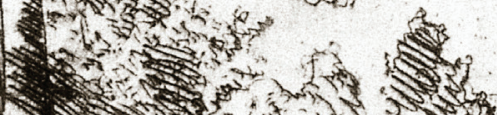
151)

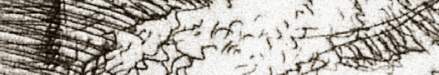

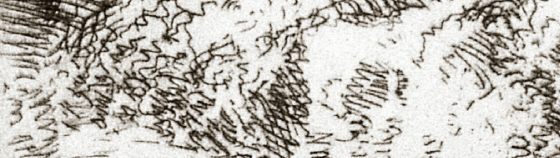

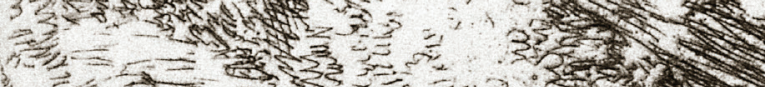

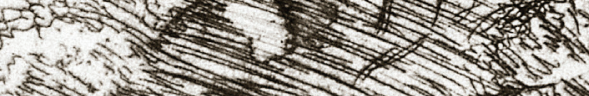
,

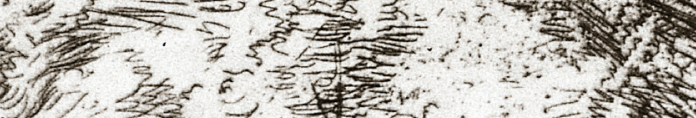
W W - . 1

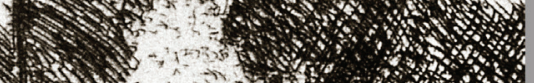

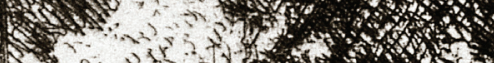

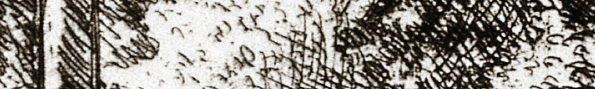
11

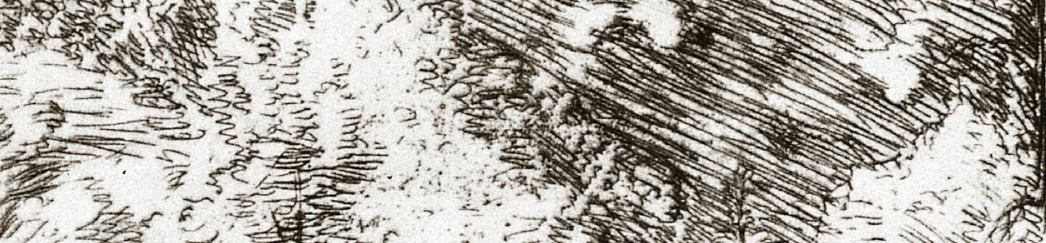

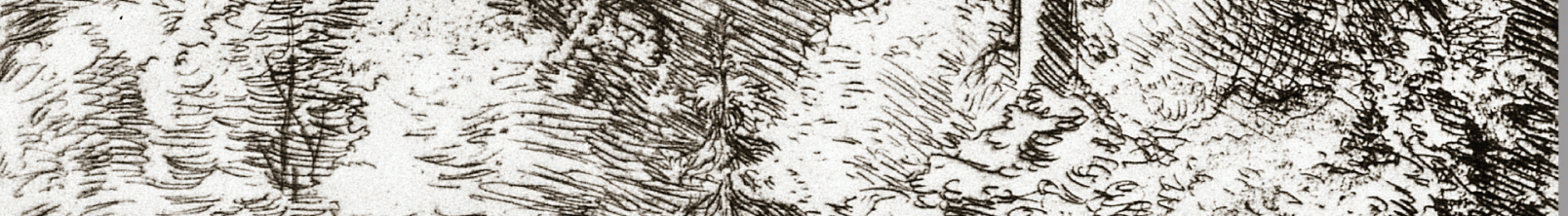

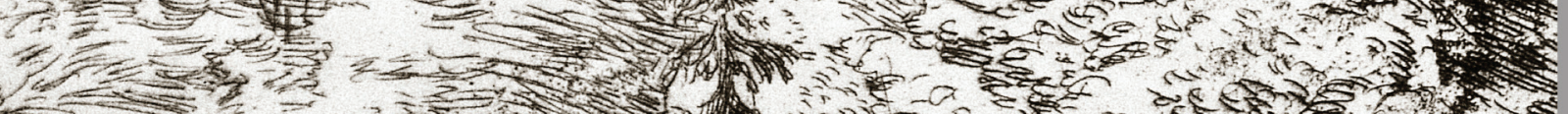

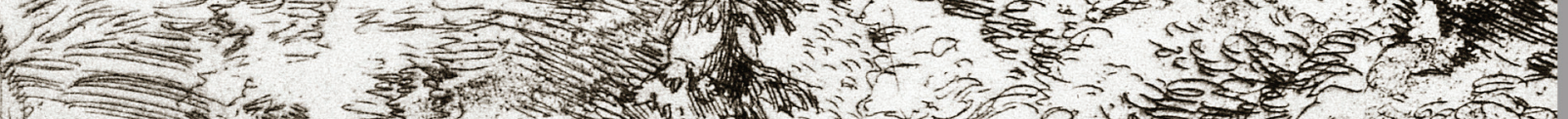

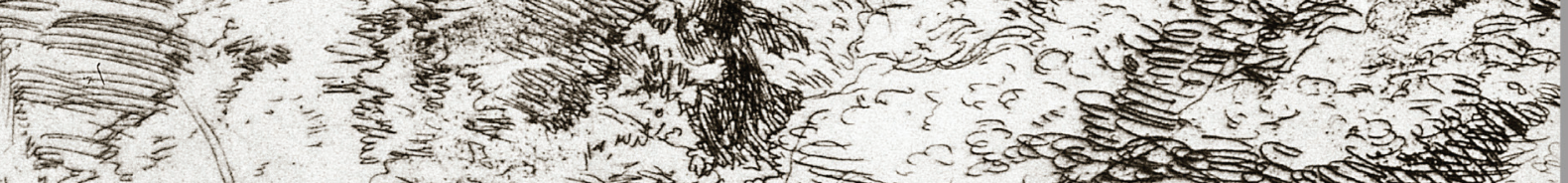

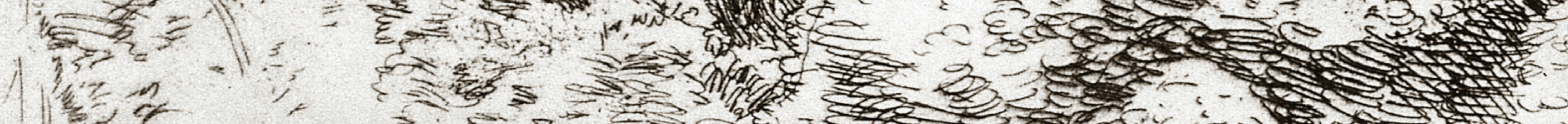

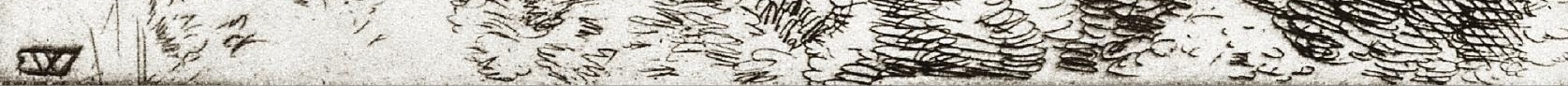

Erik Werenskiolds grafikk: raderinger og litografier Anny B. Fremmerlid 

Erik Werenskiolds grafikk: raderinger og litografier 



\section{Erik Werenskiolds grafikk: raderinger og litografier}

Anny B. Fremmerlid 
(C) Anny B. Fremmerlid 2016

Forfatteren har fastholdt sin rett til å identifiseres som forfatteren av dette verket i henhold til Lov om opphavsretten til åndsverk m.v. av 1961.

Open Access:

Med mindre annet er oppgitt, er dette verket utgitt under betingelsene i Creative Commons-lisensen CC-BY 4.0 (http://creativecommons.org/ licenses/by/4.o/). Denne tillater tredjepart å kopiere, distribuere og spre verket $\mathrm{i}$ hvilket som helst medium eller format, og å remixe, endre, og bygge videre på materialet til et hvilket som helst formål, inkludert kommersielle, under betingelse av at korrekt kreditering og en lenke til lisensen er oppgitt, og at man indikerer om endringer er blitt gjort. Tredjepart kan gjøre dette på enhver rimelig måte, men uten at det kan forstås slik at lisensgiver bifaller tredjepart eller tredjeparts bruk av verket.

Sats: Datapage India (Pvt.) Ltd.

Omslag: Erik Werenskiold, Lyse Sommer, 1914 Kat. nr. 59.

Omslagsdesign: Cappelen Damm AS, Borghild Marie Fallberg

Foto: Anny B. Fremmerlid, dersom ikke annet er oppgitt.

Digital bearbeiding: Brigitte Stolpmann

noasp@cappelendamm.no 


\section{Innhold}

Innledning

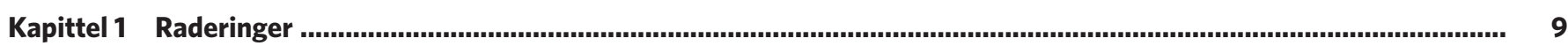

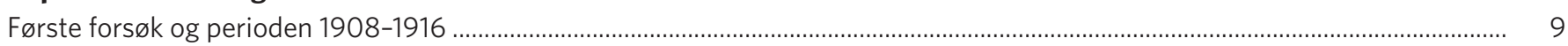

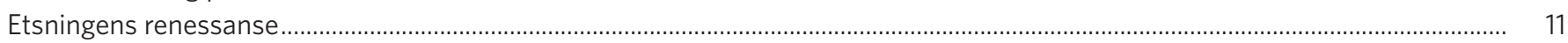

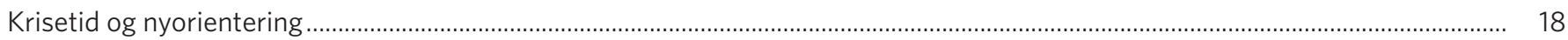

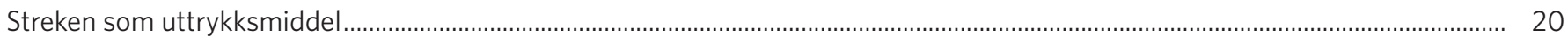

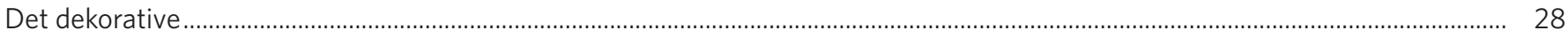

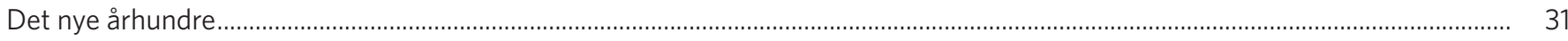

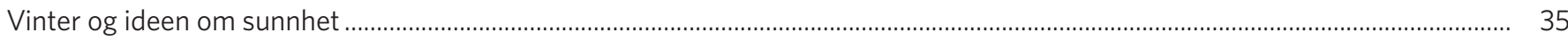

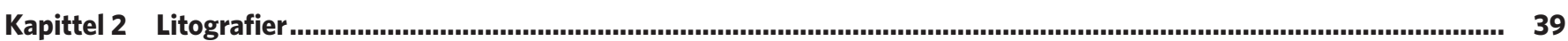

Perioden 1917-1938.

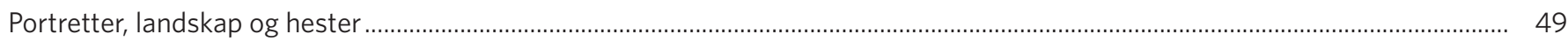

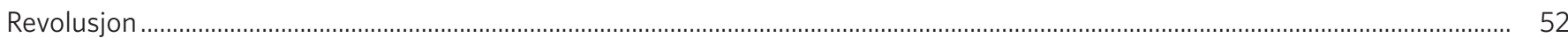

Kapittel 3 Erik Werenskiolds grafikk og Paul Cézanne .............................................................................................. 55

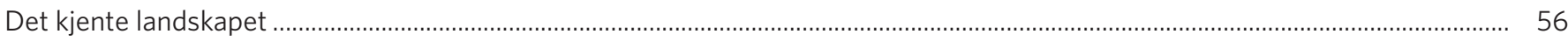

Naturen og det personlige uttrykket ..................................................................................................................................... 61

Kapittel 4 Erik Werenskiolds egne forutsetninger: Fra illustratør til utøvende grafiker ................................................. 67

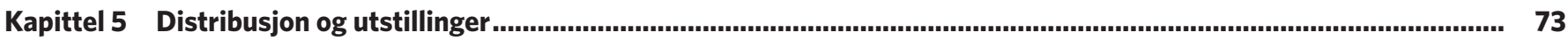

Utstillingssteder: Først ute, så hjemme ................................................................................................................................ 73

Kapittel 6 Demokratiserende aspekter i oppbyggingen av grafikkmiljøet i Norge ..................................................... 81

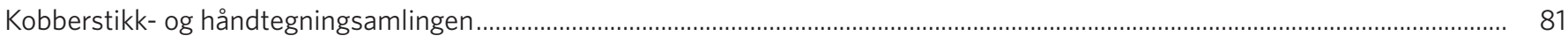

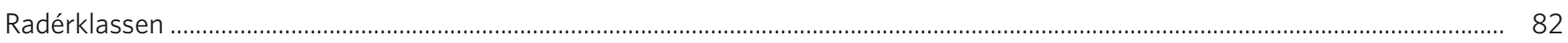

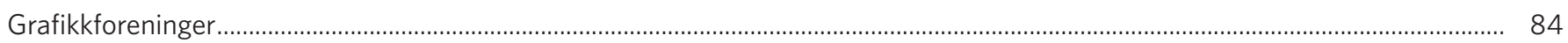

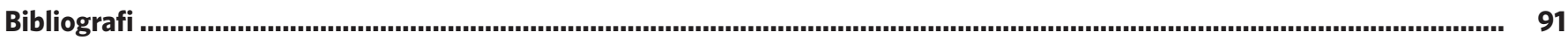


Katalog.

Trykkplate

Papir 96

Trykking......

Reproduksjonsgrafikk og autotypier

Forklaringer til katalogen

Forkortelser.

Appendiks I Gyldendal Norsk Forlag 1937

Appendiks II 3 autotypier

Bibliografi, katalog 


\section{Innledning}

Erik Werenskiolds kunstproduksjon er rikholdig. Hans malerier og illustrasjoner er velkjente. En bondebegravelse (1883-1885), September (1883) med telemarksjentene ved skigarden og illustrasjonen til «Soria Moria slott» (1884) hvor gutten hugger hodene av trollet, eller den godslige Kongen som skåler med presten (1879) i eventyret «Kullbrenneren», er motiver som mange husker. Hans grafikk derimot, er ikke på samme måten en del av vår visuelle hukommelse. Målet med denne boken er å presentere denne for ettertiden mindre kjente delen av Werenskiolds kunstnerskap. Fra tidligere finner vi noen opplysninger i spredte avsnitt i kunsthistorisk litteratur, for eksempel i Eli Engebretsen, Om grafisk kunst (1928), Kristoffer Sinding-Larsen, Norsk grafikk i det tyvende århundre (1941), Torstein Svedfelt, Erik Werenskiold (1947) og i Knut Berg (red.), Norges malerkunst (1993). En litt større omtale finner vi i Sidsel Helliesen, Norsk grafikk gjennom 100 år (2000). Boken som nå foreligger er den første som presenterer Werenskiolds grafikkproduksjon i sin helhet.

Werenskiolds grafiske oeuvre består av 247 verk, 85 etsninger og 162 litografier, og ble til i et tidsrom på 30 år mellom 1908 og 1938. ${ }^{1}$ I likhet med Werenskiolds kunst laget på 1800-tallet, har 1900-tallsgrafikken et naturalistisk bildespråk. Men innenfor de forskjellige motivkretsene i grafikken finner vi andre nyanser enn tidligere. Særlig gjelder det for en del landskapsskildringer og enkelte framstillinger av hverdagslige hendelser. Når landskapene fortoner seg på en ny måte, er det fordi de gir inntrykk av tilfeldighet i valg av utsnitt og en form for avromantisert nøkternhet. Den samme tilfeldigheten og det lite oppsiktsvekkende finner vi også i motiver som gjengir hverdagshendelsene. I andre motiver derimot opprettholdes en form for kontinuitet med forbindelser til den tidligere nasjonale naturalismens tematikk. Særlig gjelder dette motiver med hester i arbeid eller på beite og en gruppe landskap fra Heidal og fjelltraktene omkring.

Samlet sett har Werenskiolds grafikk sin største verdi som brikker i det store puslespillet om vår egen kulturelle fortid. På en nær og folkelig måte oppsummerer grafikken noen av det tidlige 1900-tallets forhold. Vi presenteres også for et stort antall portretter som viser flere av datidens toneangivende kulturpersonligheter.

Kapittel 1 tar for seg etsningene ved hjelp av korte analyser av utvalgte verk. Kapittelet setter også arbeidene inn i nasjonal og internasjonal kontekst. I forhold til det internasjonale bringes begrepet «etsningsrenessanse» inn som en forutsetning for utviklingen av etsningsmediet slik Werenskiold brukte det.

I kapittel 2 presenteres litografiets teknikk, formspråk og motiver. Kapittelet legger vekt på litografiet som en utvidelse av Werenskiolds bruk av tegningen.

\footnotetext{
1 Antallet er ifølge registreringsarbeidet som er gjort, basert på Erik Werenskiolds håndskrevne notater og grafikkoversikt og katalogen til «Minneutstilling sort og hvitt» i Kunstnernes Hus, Oslo, 6.-28.1. 1940. Ett verk som ble laget i 1904 inngår også i dette antallet, selv om det betraktes av Werenskiold som et «ørste forsøk».
} 
Det 3. kapittelet tar opp Werenskiolds møte med Cezannes kunst. Werenskiolds valg av motiver i grafikken sammenlignes med motiver i Cezannes malerier. Likheten i valg av naturutsnitt er slående, men presentasjonen av synsinntrykkene synliggjør forskjellene i de to kunstnernes formspråk. I kapittel 4 utdypes Erik Werenskiolds forutsetninger for å gå i gang med grafikk. Her legges det vekt på hans arbeid og erfaringer som illustratør. I kapittel 5 gjøres det rede for de forskjellige måtene grafikken nådde ut til publikum på, gjennom utstillinger, kommisjonssalg og innkjøp fra museer. Som en kontekstuell ramme om Werenskiolds grafikk beskrives i bokens siste kapittel oppbyggingen av et grafikkmiljø i Norge og de demokratiserende aspektene i denne tidlige fasen av vår grafikkhistorie. Erik Werenskiolds deltakelse i organisering og etablering av ulike institusjoner og foreninger i denne sammenhengen, danner et bakteppe for Werenskiold som utøvende grafiker.

Bokens innhold og oeuvrekatalog har sitt utgangspunkt i og er en bearbeidelse av hovedfagsoppgaven Erik Werenskiolds grafikk: Demokratisering av medium og motiv, Universitetet i Oslo, 2004. Takken går til Marit Werenskiold som ga tilgang til Erik Werenskiolds håndskrevne notater og grafikkoversikt. ${ }^{2}$ En stor takk går også til Werenskiolds familie for øvrig som raust og imøtekommende har gitt tilgang til det originale bildematerialet. Uten dette grunnlaget hadde verkskatalogen som presenteres her, ikke vært mulig. En stor takk til Sidsel Helliesen som har bidratt med avgjørende kommentarer og konstruktive innspill.

Anny B. Fremmerlid, mai 2016

2 Werenskiolds håndskrevne notater og grafikkoverskrift, upaginert. 


\section{KAPITTEL 1}

\section{Raderinger}

\section{Første forsøk og perioden 1908-1916}

Werenskiold nærmet seg raskt sin 48-årsdag og var godt etablert som tegner og maler da han i 1903 skrev: «Jeg hadde tænkt at begynde at radere i høst, hvis det blir tid. Men det spørs om det går. Jeg skulde hat dobbelt så meget kræfter som jeg har, så skulde jeg udrettet noget ordentlig her hjemme.» ${ }^{1}$ Og året etter, i april 1904, skrev Werenskiold til Bernt Grønvold: «Jeg begyndte i forrige uge at radere, men min arm er ikke bra for øieblikket. Men jeg skal nok lære den kunst, og jeg håber jeg skal få glede av den.»²

Det skulle han få. Helt fram til 1938, det året Werenskiold døde, kom grafikken til å oppta ham. Først i form av raderinger, siden tok litografiet over. Men det skulle vise seg at det i 1904 bare ble med dette ene forsøket. Werenskiold hadde på dette tidspunktet lagt bak seg en rekke illustrasjonsoppdrag. Den siste illustrasjonen til Jonas Lies roman Familien på Gilje ble levert i mars 1904, og allerede måneden etter gjorde han sitt første forsøk på å radere.

Streketsningen har påskriften «Første forsøk» utenfor trykkflaten i nedre venstre hjørne. Det er et vintermotiv med fire hus antydet i bakgrunnen. En elv flyter rolig forbi og danner et uregelmessig mørkt felt, som avgrenses av snødekte områder langs elvebredden. Werenskiold fører etsenålen i skraverende bevegelser og skiller de ulike elementene i motivet fra hverandre ved hjelp av det hvite i arket og forskjellige retninger på skraveringene. Diagonale streker dominerer bakgrunnen. Her gir skraveringene den samme gråtonen uavhengig av om de gjengir landskap, en diffust antydet himmel eller et hustak. Takene har en avgrensning som er markert med omrisslinjer, mens husveggenes langsider er markert med langsgående, tettere streker som gir en mørkere valør. Trykket er ikke oppført i Werenskiolds håndskrevne verksoversikt, som har vært utgangspunktet for katalogen i denne boken. Grunnen til at etsningen ikke er inkludert i opusrekken, kan ha vært at han betraktet dette arbeidet nettopp som et forsøk. Etsningen viser imidlertid Werenskiolds iver etter å komme i gang med grafikk som et nytt kunstnerisk medium, rett etter at han hadde fullført det store illustrasjonsarbeidet til Familien på Gilje. Etsningens motiv kan for så vidt være hentet fra et elvedrag hvor som helst i landet, men en påskrift på en tilnærmet

Brev fra Erik Werenskiold (EW) til Bernt Grønvold (BG) datert 13.10. 1903.

Brev fra EW til BG datert 17.4. 1904 


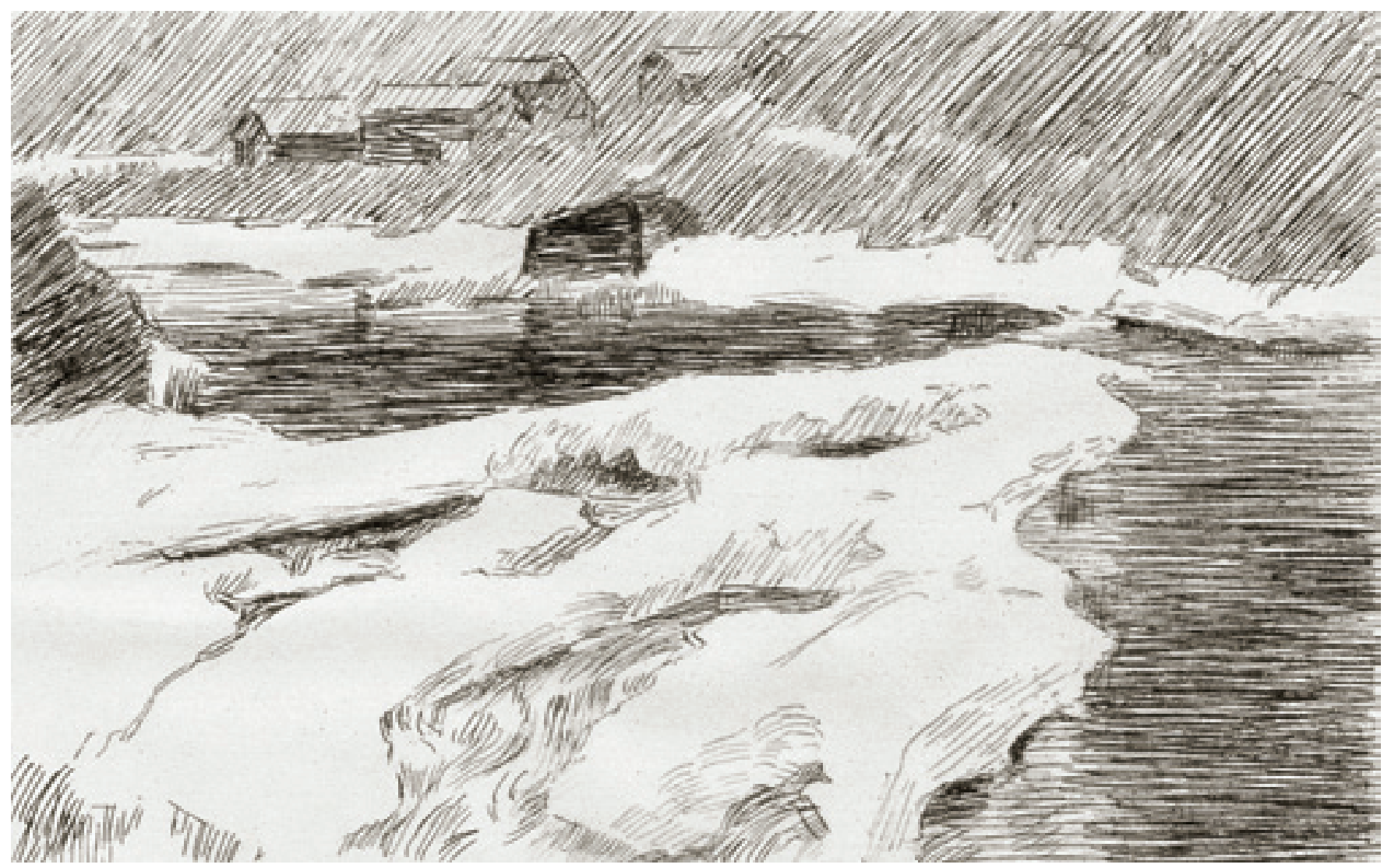

Første forsøk, 1904. Streketsning (Kat.nr. 1)

identisk tegning som eies av Nasjonalmuseet i Oslo, har påskriften «Bagn 1893», og arkivopplysninger bekrefter at tegningen er en illustrasjon til Lies roman. ${ }^{3}$

I sin bok Norsk grafikk gjennom 100 år skriver Sidsel Helliesen: «Muligens fant det første forsøk sted i 1904, men den egentlige starten må regnes til 1908-1909.» Leif Østby skriver i boken Erik Werenskiold: «Det vesentligste nye i hans svartog hvitt-kunst i denne senere halvparten av hans liv er grafikken, som opptar ham sterkt fra han i 1908 laget sine første raderinger, [...].»5 I juni 1908 kan vi lese i et brev som Werenskiold skrev til sin kunstmesen og venn Bernt Grønvold: «Kjære Bernt Grønvold. [...] idag tok jeg en raderplate og begynte at klore på.» ${ }^{6}$ Og ni måneder senere skriver han igjen til Grønvold: «Nu, jeg hadde egentlig tænkt at reise for at trykke raderinger; men jeg har ikke mer end 5 foreløpig, så det er

3 Nasjonalmuseet for kunst, arkitektur og design, Oslo. Ill. til Jonas Lie, Familien på Gilje, 1904. Tegning datert 1893, Inv.nr. NG.K\&H.B.05003.

$4 \quad$ Helliesen, Norsk Grafikk gjennom 100 år, 88.

5 Østby, Erik Werenskiold, 239.

6 Brev fra EW til BG datert 12.6. 1908. 
for lite, jeg vil allermest [?] ha et halvt snes.» ${ }^{7}$ Og så endelig i juli 1909 kunne Werenskiold meddele sin gode venn at syv raderinger dagen før var sendt til ham i Berlin. ${ }^{8}$ Den eneste raderingen som nevnes med tittel i dette brevet, er Høyfjell. De andre må sannsynligvis ha vært Den engelske flåte, Bjørnstjerne Bjørnson i slåbrok og Lysakerbrua, vinter, alle radert i 1908 og trykt i 1909. I tillegg finner vi Venninner, Nansens hus, Polhøgda og To gutter. Disse sist nevnte er laget i 1909. ${ }^{9}$

Ved hjelp av opplysninger fra den rikholdige korrespondansen mellom Erik Werenskiold og Bernt Grønvold kan det, som påpekt, slås fast at en sped begynnelse fant sted i 1904, men at han først i 1908-1909 fikk fart på grafikkproduksjonen, slik Helliesen opplyser i sin tekst. I løpet av sommeren og høsten 1908 laget han altså ferdig flere kobberplater. I oktober rapporterte han nok en gang til Grønvold at han hadde en del ferdige plater, og at han i tillegg var tilfreds med resultatet. «[... nu begynder jeg at kunne det; en plate er udmerket, en kan bli god, i det hele ser jeg at det ligger let til for mig og min tegnekunst står godt til. Jeg tegner direkte på platen efter naturen..$^{10}$ Og endelig, en gang mellom 15. mars og 1. juli 1909 fikk han mulighet til å trykke de første bladene. Werenskiold behøvde med andre ord ikke særlig lang tid for å føle at han var på god vei inn i den nye uttrykksformen. I løpet av noen ganske få måneder begynte han å bli tilfreds, og så med optimisme på prosjektet. I 1910 skriver han: «Nu kan jeg selv grundere en plate og trykke en radering, og jeg skal bli en god teknikker.» ${ }^{11}$

\section{Etsningens renessanse}

Begrepet radering brukes av Werenskiold synonymt med etsning. ${ }^{12}$ Hans raderinger finnes i tre varianter: streketsninger, en kombinasjon av streketsning og koldnål og en kombinasjon av akvatintetsning og koldnål. Ordet radering kan også brukes som en fellesbetegnelse på alle former for dyptrykk. ${ }^{13}$ Raderingsteknikken innebærer at motivet vanligvis tegnes inn i en etsegrunn med etsenål, et redskap som ligner en koldnål, men som har en litt annen, mer avrundet spiss. Linjene tegnes $\mathrm{i}$ grunderingen så dypt at metallplatens overflate blottlegges. Spor i selve platen må unngås. Det karakteristiske for streketsningen er at etsenålen kan føres i alle retninger uten at den utsettes for motstand fra platen. Måten å arbeide med nålen på er høyst individuell, men som allmenn regel gjelder det at linjene ikke må legges så tett at de går i hverandre, og at linjene som skal etses kraftig, bør ha større avstand seg imellom enn andre.

Rent teknisk innebærer det å tegne direkte på platen at det er vanskelig å korrigere motivet. Skal det gjøres, må etsegrunnen helt eller delvis legges om etter prøvetrykking. Werenskiold hadde lite til overs for denne formen for bearbeidelse, «[...], og flere plater er så godt som ikke rørt efter ætsningen: Jeg skal med lit mer erfaring sikkert gjøre dem fuldt færdige

Brev fra EW til BG datert 15.3. 1909

Brev fra EW til BG datert 1.7. 1909.

Werenskiolds håndskrevne notater og grafikkoversikt, upaginert.

Brev fra EW til BG datert 26.10. 1908. NB. Håndskriftsamlingen, brevs. nr. 98.

Brev fra EW til BG datert 18.10. 1910. NB. Håndskriftsamlingen, brevs. nr. 98.

12 Schantz og Arkö, Vad är grafik. En handbok i grafisk konst, 31. Siden Werenskiold konsekvent benyttet begrepet på samme måte, vil Schantz og Arkös definisjon gjelde i denne oppgaveteksten.

13 Helliesen, Norsk grafikk gjennom 100 år, 304. Helliesen bruker den vide forståelsen av ordet radering i sin tekst. 


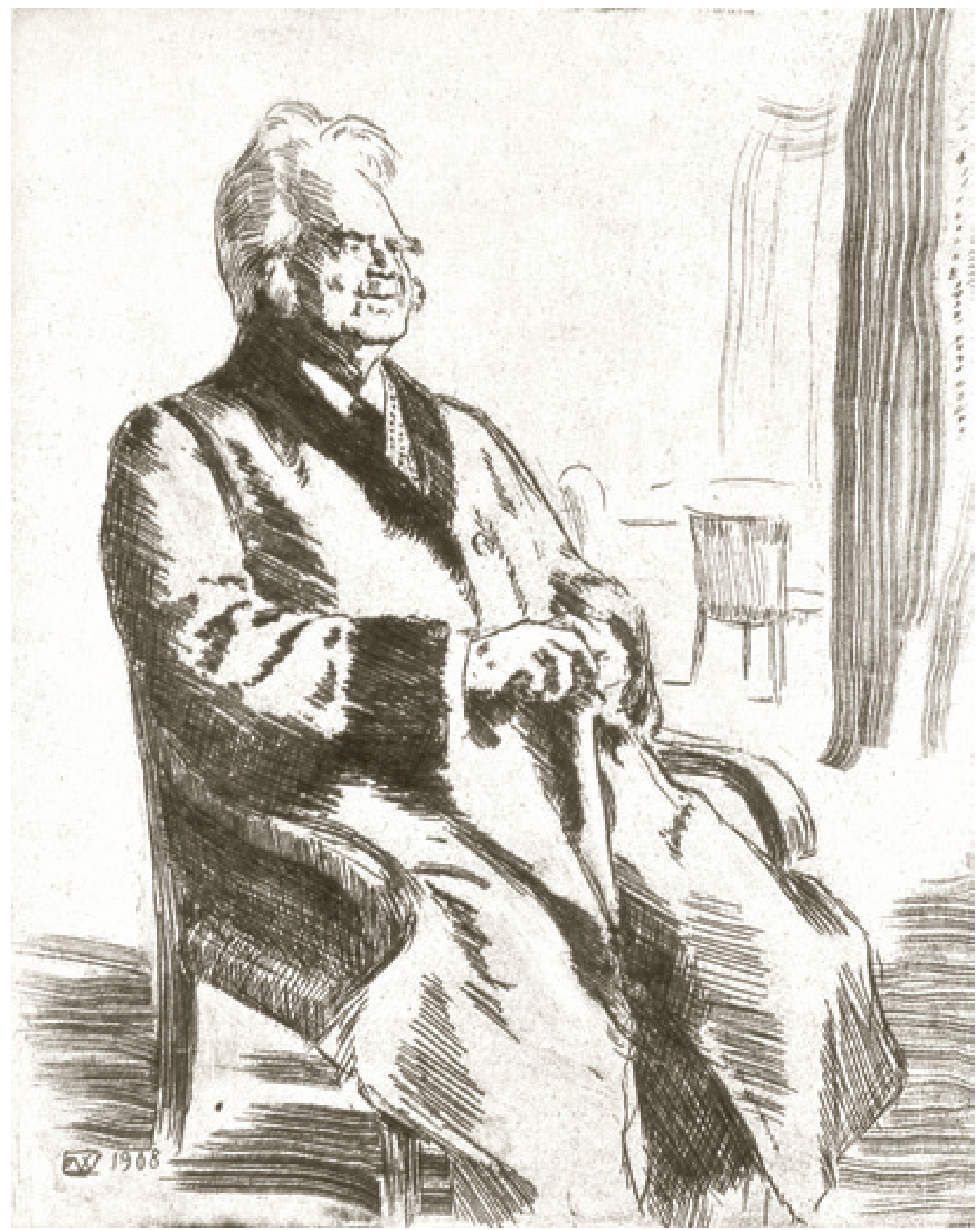

Bjørnstjerne Bjørnson i slåbrok, 1908-1909. Streketsning (Kat.nr. 6) 
med en gang uten overarbeidelse etterpå. Den filingen og poleringen er jeg lite for.. ${ }^{14}$ Men i noen tilfeller tok han allikevel koldnålen i bruk slik at han på en mer direkte og umiddelbar måte kunne justere feil eller mangler i motivet uten å gå veien om en ny og mer omstendelig runde med etsegrunn og syre.

Akvatintetsning blir til ved å etse en mengde bitte små flekker eller fordypninger i platen. For øyet flyter disse flekkene sammen til en tonet overflate. Fordypningene lages ved at platen, før den legges i syrebadet, pudres med asfaltpulver eller harpikskorn. Platens underside varmes forsiktig opp slik at pulveret smelter inn i etsegrunnen uten at det blir til en heldekkende flate. Hensikten er at syren skal bite seg ned i platen mellom de fastsmeltede kornene. I det ferdige trykket framstår de punktene som er beskyttet mot syren, som små hvite prikker. I en finkornet akvatint er prikkene nesten ikke synlige for det blotte øyet. I en grov akvatint derimot kan disse bli mer enn en millimeter store. ${ }^{15}$

«Tegnekunst direkte på platen etter naturen» er beskrivende for Werenskiolds raderinger. Med denne framgangsmåten, som han ofte understreket i brevene til Grønvold, og som han beskrev på en av de første sidene i sin håndskrevne grafikkoversikt, knyttet Werenskiold seg til den såkalte etsningsrenessansens tekniske idé og estetiske fordring; det naturalistiske eller realistiske konseptet uten forutgående skisse, hvor motivet ble tegnet rett på bunnmaterialet. På slutten av 180o-tallet ble denne framgangsmåten gjerne tatt $\mathrm{i}$ bruk av kunstnere som hadde sitt primære utgangspunkt i maleriet. ${ }^{16}$ Ofte var disse kunstnerne selvlært som grafikere, og den direkte og spontane utførelsen skulle gi et autentisk og fritt bildespråk, noe som er karakteristisk for etsningsrenessansens estetiske kvaliteter. Den oppblomstringen som fant sted ute i Europa mellom 1850 og 1890, spesielt i Frankrike og England, hadde fokus på etsningens originalitet. ${ }^{17}$ De viktigste inspirasjonskildene for disse europeiske kunstnerne var først og fremst å finne blant 1600-tallets nederlandske kunstnere med Rembrandt i spissen. ${ }^{18}$ Werenskiolds raderinger ble altså til i kjølvannet av denne revitaliseringsbølgen.

Den nye etsningen kom til å stå i opposisjon til bildemedier som først og fremst ble forbundet med ulike former for reproduksjon uten kunstneriske intensjoner per se, slik som for eksempel den eldre kobbergrafikken, det tidlige litografiet eller fotografiet. ${ }^{19}$ Konsekvensen ble at de som engasjerte seg i etsningsbevegelsen, framhevet autentisiteten i den nye og friere etsekunsten. For å markere skillet mellom det reproduserende og det kunstneriske trekkes formale forbindelseslinjer til maleriet eller de maleriske kvalitetene i pennetegningen, gjerne i en skisseaktig utførelse. Ved å framheve dette slektskapet kobles etsningen til en fri og autografisk kunstform som kan formidle kunstnerens særegne uttrykk.

Perioden har fătt betegnelsen «The Revival of Etching» eller «etsningsrenessansen». I grafikkhistorien regnes etableringen av La Société des Aquafortistes i Frankrike i 1862 som et merkeår i denne sammenhengen. I grafikkforleggeren Alfred Cadarts tidsskrift L'Eau-forte som utkom i Paris i andre halvdel av 1800-tallet, skrev franske etsningsentusiaster glødende innlegg om

Brev fra EW til BG datert 1.7. 1909. NB. Håndskriftsamlingen, brevs. nr. 98.

Schantz og Arkö, Vad är grafik. En handbok i grafisk konst, 45-46.

Helliesen, Norsk grafikk gjennom 100 år, 32.

17 I Frankrike var det grafikkforlegger Alfred Cadart, trykkeren Auguste Delâtre og grafikeren Félix Braquemond som utgjorde et viktig trekløver i etsningsbevegelsen. I England er grafikerne James McNeill Whistler og Francis Seymour Haden fremtredende navn.

18 Helliesen, Norsk grafikk gjennom 100 år, 32.

19 Ibid., 36-37. 
dette kunstmediets fortreffelighet. I positive ordelag understreket de etsningens originalitet og mulighet til å reflektere kunstnerens personlighet. ${ }^{20}$ At den har samme uttrykksregister som pennetegningen, passet Werenskiold spesielt godt.

Grafikkforeningenes iver etter å markedsføre etsningen som et kunstnerisk medium som ikke lenger skulle forbindes med nyttegrafiske reproduksjoner, gikk hånd i hånd med utviklingen av fotomekaniske trykkeprosesser. Den trykktekniske nyvinningen gjorde det nå mulig å spre bilder av alle slag til mennesker i alle samfunnslag. I de tidlige europeiske grafikkforeningenes formålsparagrafer ble det derfor trukket en skillelinje mellom de originale, autografiske grafikkmediene på den ene siden og de kommersielt utnyttbare på den andre siden. Mange har oppfattet etsningsrenessansen som en svært viktig hendelse i grafikkhistorien, mens andre, blant dem William M. Ivins jr., har karakterisert fornyingen av etsekunsten som «one of the greater ironies [...] which the books tell us began about the middle of the nineteenth century, [and that it] was actually not a revival of the craft of etching at all but the adoption of the technique by a group of on the whole rather poor draughtsmen and incompetent technicians who in one way or another managed to gain the attention of the public. ${\aleph^{21}}^{21}$ Uansett hvordan grafikkhistorikerne valgte å se det, var resultatet at kunstnere, kritikerne og publikum begynte å legge vekt på originalitet som en vesentlig kvalitet også i grafikkmediet. Etter hvert førte dette til at den fornyede etsningen vant fram i det kommersielle kunstmarkedet. ${ }^{22}$

«Maleriets lillesøster» var et smidig medium. ${ }^{23}$ Det tilårskomne kobberstikket, matematisk i sin nøyaktighet, ble ansett som stivnet og kreativt lite tilfredsstillende av etsningsrenessansens tilhengere. Kobberstikket holdt stand mot de nyere prosessene til midt på 180o-tallet, og ble senere i samme århundre først og fremst verdsatt «through the snobbery of a tradition of the best». ${ }^{24}$ Etsningen, ansett som et mer vitalt kunstnerisk medium, var uten krav til «the laying of lines, swelling and diminishing, the creation of webs of crossed lines, of lozenges with little flicks and dots in their middles». ${ }^{25}$ Den gamle grafikkens mange ulike grammatikalske eller syntaktiske regelstyrte nøyaktighetssystemer ble betegnet som «the tyranny of the rule». ${ }^{26}$ Etsningsrenessansen opphevet dette «tyranniet». Erik Werenskiold utviklet $\mathrm{i}$ tråd med dette sin særegne autografiske tegnemåte på metallplaten.

Til denne historisk sett korte perioden i internasjonal dyptrykkhistorie hører den såkalte le paintre graveur eller malergrafikeren. Adam von Bartsch har blitt kreditert uttrykket; han bruker ikke begrepet ennå i sin Catalogue raisonné utgitt i 1797, men beskriver malergrafikerens arbeidsmåte ved å vise til Rembrandt som en kunstner som arbeider med etsninger som om det var et maleri. ${ }^{27}$ Da Bartsch i 1803 utga første del av Le Peintre Graveur, inngikk begrepet som vi forstår, i selve tittelen på det store katalogverket. Her lot han begrepet også gjelde kunstnere som selv reproduserte egne malerier i form av raderinger ${ }^{28}$ Ifølge Bartsch har disse raderingene beholdt noe av den opprinnelige, maleriske, frie formkvaliteten

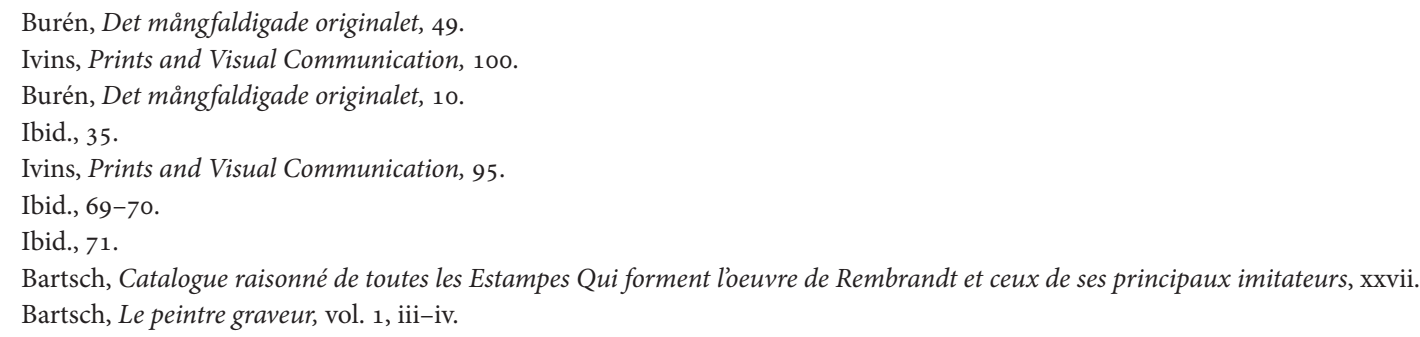


som kan ses i forlegget. En kvalitet som det er umulig å oppnå i en reproduksjon dersom den er utført av en annen enn kunstneren selv.

Rembrandt, som ble et forbilde for malergravørene, utførte etsninger med lett antydede streker ofte i en kombinasjon med tykke, tydelig markerte linjer og frie skraveringer. De har en uvøren og løssluppen karakter. De har en slags malerisk uorden. Rembrandts etsninger viser en velutviklet forståelse for lys- og skyggemodellering. Han blandet ofte koldnål og etsning i ett og samme verk. Rembrandt fulgte ingen regler. Werenskiold refererer til dette maleriske bildespråket hvor streklagene uttrykker «form og farge på en gang». Rembrandt fascinerte ham også gjennom sin spesielle evne til å oppfatte nyanser i sinnsstemninger, som han på en innsiktsfull måte oversatte til visuelle manifestasjoner. ${ }^{29}$ «Man føler hans sjæle-

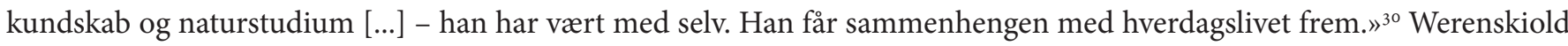
fulgte heller ingen formelle regler for hvordan en radering skulle bygges opp, men vekslet fritt mellom lette riss og tette streklag som om det var en malerisk utført tegning. En litt uvøren utførelse ble karakteristisk for den nye måten å bruke etseteknikken på. Sidsel Helliesen beskriver resultatet som «en lett ruskete flekkvirkning i billedflaten». ${ }^{31}$ Hos Werenskiold finner vi i tillegg en grålig, ujevn platetone som forsterker denne litt slentrende uvørenheten, for eksempel i verk som Venninner (1909), Gran og furu med snø på (1912) og Nedsnødde smågraner (1913).

Rent formalt ble malergrafikeren stilt i en særstilling sammenlignet med grafikere som jobbet i forhold til det nyttegrafiske. Særstillingen tillot ham «att antyda istället för att imitera».32 Å tegne etter naturen var ikke ensbetydende med en nøyaktig registrering, men naturen skulle være utgangspunktet for det kreative uttrykket. Malergrafikerne har blitt karakterisert som venner av pensel og penn, og fiender av maskiner og fylt av respekt for håndens geniale og åndfulle arbeid. ${ }^{33}$

Radérkunstens forhold til Rembrandt gjennomsyrer mye av stoffet knyttet til 180o-tallets etsningsrenessanse: Det autentiske, det originale og malergrafikeren hører sammen i en kreativ enhet. Rembrandts 1600 -tallsetsninger har blitt tildelt mye av æren for utviklingen av en friere bruk av etsenålen. ${ }^{34}$ «[...] Rembrandt here takes the first step on the way to a new style, which was to inform all his later work. Large areas of cross-hatching and continuous dark outlines are abandoned, while the figures and the foreground and background are set down more loosely and sketchily. Areas has been left open and dark accents and shadows have been placed so as to intensify the effect of the light. This drawing-like style was of course only possible because the artist could move the etching needle freely in the etching ground. Rembrandt is the first artist to have imbued the etching technique with the character of a drawing in such a thoroughgoing fashion. $»^{35}$

Ifølge Jan af Burén har kunsthistorien skapt en «Rembrandtgestalt» som ettertiden har brukt som referanse i etableringen av den europeiske «Etching Revival». Han har blitt en slags tillitvekkende og beundret garantist for den nye bruken av etseteknikken. ${ }^{36}$ I et brev til Grønvold tidlig på året i 1903 skrev Werenskiold om sin beundring for Rembrandt og Keen. «Jeg har netop i det aller

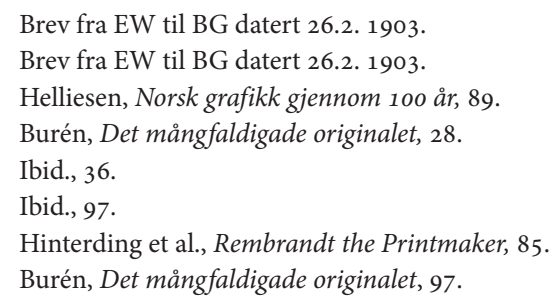




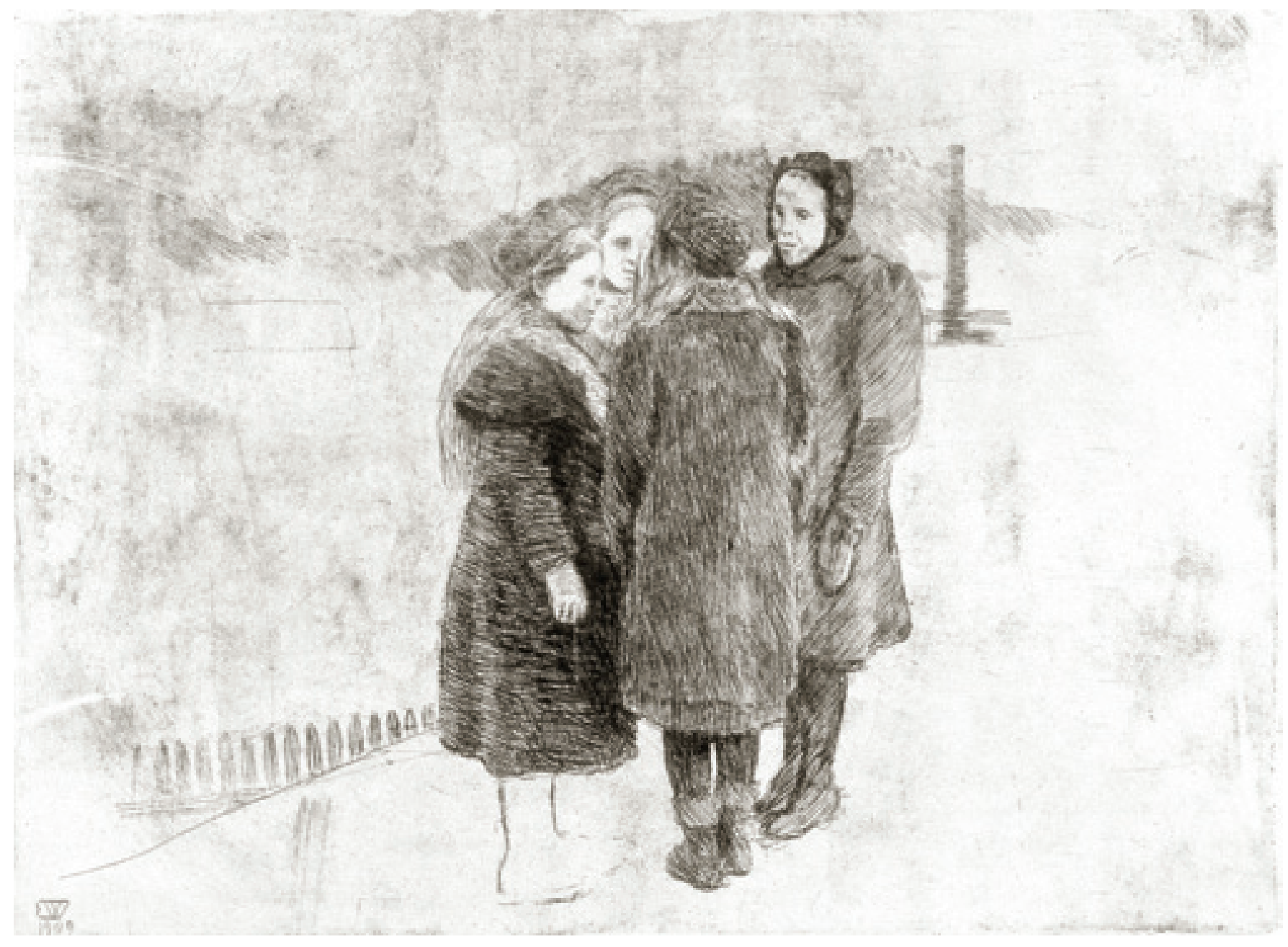

Venninner, 1909. Streketsning (Kat.nr. 8)

sidste gjort, hvad jeg ellers ikke pleier, - nemlig lagt noen utmerkede tegninger av Rembrandt og Keen ved siden av mine egne. Det er gode læremestre. Især Rembrandt, som jeg føler mest for, fordi han dels er mer malerisk, dels har han en måde at fornemme hvordan streglagene best udtrykker form og farve på en gang. [...] Han er mesteren over alle mestere.»37

Til tross for sin kunstneriske selvstendighet og modne alder henviste Werenskiold altså til Rembrandt som inspirator. Med denne referansen sluttet Werenskiold seg til det professor i kunst- og bildevitenskap Lena Johannesson karakteriserer som en «heroisk» tradisjon i grafikkhistorien..$^{38}$ Men også Francisco Goya kan nevnes i denne sammenhengen.

37 Brev fra EW til BG datert 26.2. 1903.

38 Johannesson, «Fenomenet Zorn - världs- och verklighetserövran», 123. Johannesson bruker ordet «heroisk» for å karakterisere Rembrandts posisjon i den ansiennitetsfikserte kunsthistorietradisjonen. 


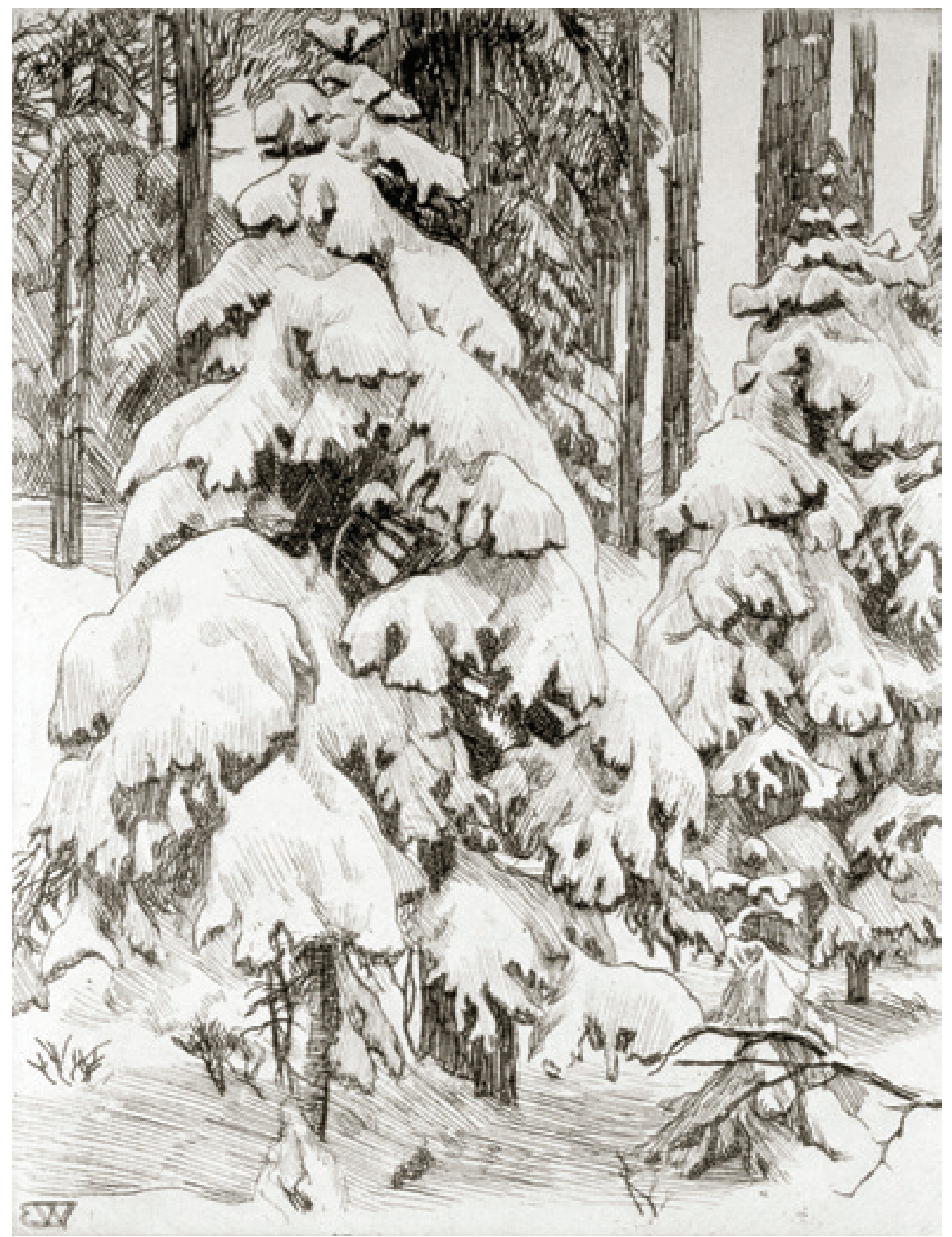

Nedsnødde smågraner, 1913. Streketsning (Kat.nr. 39) 
Werenskiold hadde også latt seg fascinere av Goya og lå våken om nettene og tenkte på hans akvatinter. På vårparten i 1907 hadde han fått noen bøker om Goya fra Grønvold i Berlin. «Du kan tro jeg blev glad da jeg fik den storartede overraskelsen, Goya, og så at begge bøkene var til mig! Jeg ble så [...] begeistret, at jeg bare lå og tænkte på raderinger hele natten. Ja havde jeg set dette før, for et snes år siden - men jeg er fornøiet over at se det nu; det er noget forløsende i det, og jeg vil prøve at lære denne ætsning med korn.» ${ }^{39}$ Til tross for denne begeistringen for Goya, laget Werenskiold bare to akvatintetsninger. Eller kanskje ikke å undres over allikevel siden akvatintens kvaliteter er mer i slekt med akvarell og lavering. Dette var arbeidsmåter og medier som Werenskiold hadde lite eller ingen erfaring med fra tidligere. Av formale trekk hos Goya merket han seg de «korte, butte forhold, de butte vinkler og noget tæt og fast».40 Det var noen av de samme kvalitetene som Werenskiold kom til å legge merke til hos Cézanne da han så hans malerier i Pellerins samling i Paris i 1908, en opplevelse som ble svært viktig for Werenskiolds utvikling som kunstner. Slik passet Goya godt inn i Werenskiolds idé om en justering av bildespråket som skulle gi en strammere form med mindre fokus på detaljer enn det som var tilfellet i hans penne- og blyanttegninger før 1900. Med sin begeistring for Goya kommer Werenskiold ut av det som Burén betegner som «det historiografiska isolat man har upprättat kring The Etching Revival, [och] den genomgående lågmälda behandlingen av särskilt

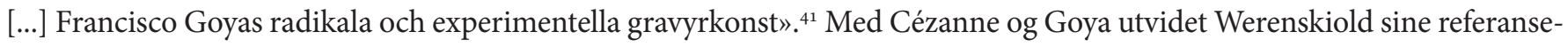
rammer, uten at vi dermed kan hevde at Werenskiold valgte å eksperimentere med mediet. Men gjennomgående har Werenskiolds raderinger et variert formspråk. Valget av teknikker falt på etsning og litografi, som er uttrykksformene spesielt godt egnet i forhold til Werenskiolds tegneferdigheter. Teknisk kan hans grafikk betegnes som en utvidelse av tegnefeltet.

Werenskiold og hans malerkollegaer som begynte å radere skilte seg fra tidligere generasjoners grafikere ved at de som oftest ga seg i kast med grafikken uten å gå veien om en grundig utdanning i faget. Ikke på noe tidspunkt ser det ut til at Werenskiold fikk formell undervisning i etsningsteknikken. Eli Greve skriver riktignok i boken Om grafisk kunst at Werenskiold «[i] 1907-08 gik [...] en kort tid hos Nordhagen og erhvervet sig den nødvendige tekniske indsigt, [...]».42 Dette dreide seg mest sannsynlig om en mer uformell veiledning, siden Werenskiold ikke finnes oppført i protokollene som ordinær elev i Nordhagens Radérklasse ved Den kgl. norske Kunst- og Haandværksskole i Christiania. Materialkunnskap og håndverksmessig ferdighet kom til gjennom praktisk erfaring med mediet.

\section{Krisetid og nyorientering}

Werenskiold hadde sterke meninger om kunstens formale sider. I det praktiske etterstrebet han å kombinere sin teoretiske holdning med sitt eget formale gehør. I Andreas Auberts artikkel om Erik Werenskiold fra 1904 kommer Werenskiold selv til orde gjennom et sitat som i tid ligger tett opp til hans første utførte radering. «Imidlertid havde jeg i Nittiårene leveret illustrationer til Snorres kongesagaer. Disses art førte mig ind på en større forenkling og mere afveiet komposition. Tillige måtte jeg sætte mig ind i middelaldersk ornamentik. Her slog det mig voldsomt at det middelalderske var så fast, så bredt og stærkt,

\footnotetext{
Brev fra EW til BG datert 7.3. 1907.

Werenskiold, «Rembrandt og Cézanne», 97.

Johannesson, «Fenomenet Zorn - världs- och verklighetserövraren», i Birgitta Sandström (red.), Zorn i svart och hvitt, 122.

Ingebretsen, «Om norsk grafisk kunst», 70.
} 
medens det moderne flød ud, slapt og vegt. Dette kom deraf at det middelalderske var holdt kraftig sammen af en ornamental grundform eller arkitektonisk inddeling, og ind i denne voksede ornamentet helt, tæt, afrundet og fyldig; aldrig slapt og viljeløst. Den ene form og den ene linje havde altid føling af sin nabo. Ved udsmykningen af Nansens spisestue, som jeg har under arbeide og som (endnu nu i juli 1904) langtfra er færdig, kom jeg ind på følgende tankegang: Naturalismen har hobet op et umådelig stof, en umådelig masse spredte naturiakttagelser. Den har skabt en sund, fin og sandfærdig kunst; men ved sit strenge krav til stadig konferance med naturen bandt fantasien, gjorde alting så tungvindt og hindrede den stærke personlige udfoldelse. [...] Samtidig har Japaneseriet, Puvis de Chavannes og andre gjenoplivet kunstens dekorative side, udsmykningsidéen, som naturalismen virkelighedsiagttagelse havde glemt og ladet dø. Så åbner sig med engang veien for en fri og stærk personlig udfoldelse på naturbetragtningens grund - på den grund som naturalismen og impressionismen har lagt. Thi det er dumt at gjøre som de forfattere, der af afsky for naturalismen løber over i katholicismen og mysticismen og råber: «naturalismen er fienden!» Det er jo bare barnagtighed. I alle de små bevægelser, mysticisme, symbolisme og andre ismer er kun én fornuftigt fællestræk, bestræbelsen for at indføre den dekorative side og for så vidt at befri sig for naturalismens tvang. Derfor dør selve retningene en hurtig død, mens kunsten styrer rolig videre mod den store renaissance på det 19de århundredes grundlag, og den er vi ved begyndelsen af ... Den stærke personlige udfoldelse er betingelsen for al stor blomstring.»43

Werenskiolds refleksjoner rundt kunstens form og innhold handler kort sagt om to viktige prinsipper: den frie og sterke personlige utfoldelsen kombinert med evnen til å gjenskape inntrykk fra naturen. Han grep fatt i de inspirasjonskilder som tangerte hans egne oppfatninger. Med dette i bagasjen gikk han løs på utfordringene som lå i grafikken. Inspirert til å utvikle et personlig uttrykk, fortsatt basert på naturen i kombinasjon med fremragende tegneferdigheter, lå veien åpen for utfoldelse på et nytt kreativt område. I 1903 hadde han uttalt at han ville bruke tiden til å eksperimentere med forskjellige materialer. Han følte at han hadde gått i de samme sporene og de samme omgivelsene for lenge, «og tilslut blir man indgjæret i en kreds som sletikke er videre egnet for ens maleri. Jeg lengter ofte til fattigfolk og alminnelige mennesker - efter at være alene kanske aller mest.» ${ }^{44}$ Det detaljerte i Werenskiolds malerier og tegninger fra tiden før århundreskiftet var ikke lenger fullt ut tilfredsstillende for hans kunstneriske intensjon.

Mens den nye kreativiteten i kunstuttrykket fikk modnes i ham, fortsatte han med olje, penn, kullstift og akvarell. Han var med på å starte en forening for bokkunst (1900) og et raderforlag (1903), han gjorde ferdig dekorasjonen Liti Kjersti i spisestuen på Polhøgda (1907) og laget tapetmønster til Nansen med elger og trær, han la, som nevnt ovenfor, siste hånd på illustrasjonene til Familien på Gilje, søkte kunnskap og gjenklang i andre kunstneres produksjon, utformet dekorative mønstre som hans kone Sophie Werenskiold broderte, og laget altså sin første radering. ${ }^{45}$

Krisetiden som maler var, som vi forstår, på ingen måte uvirksomme år. Og omtalt med et annet fortegn kan årene betegnes som kreative forsøksår. Han kunne forblitt utilfreds og resignert, men hans pågangsmot og nysgjerrighet drev ham videre til nye løsninger i kunsten. Uroen og utilfredsheten skulle vise seg svært fruktbar etter hvert.

43 Aubert, Norsk kultur og norsk kunst, 191-192.

44 Brev fra EW til BG datert 31.1. 1903.

45 Brev fra EW til BG datert 13.10. 1903. Werenskiold skriver: ... «har dannet et raderforlag, noe jeg visst fortalte deg i forrige brev.» Opplysninger om «raderforlaget» er ikke funnet i tidligere eller senere brev skrevet til Grønvold datert i 1903. Det har så langt heller ikke vært mulig å finne annen informasjon om «raderforlaget». 
Ut av «krisen» kom han først i 1908. Dette året markerer en ny tid for Werenskiold, både som maler og grafiker. For maleriets del ble Paul Cézanne den nye, store inspiratoren, og eksperimenteringen med materialer førte endelig til at han med fornyet glød gikk løs på den utfordringen som lå i raderingene. I så forskjellige inspirasjonskilder som middelalderens ornamenter og Cézannes maleri fant han støtte for et uttrykk hvor han kunne bruke sin særdeles velutviklede observasjonsevne i kombinasjon med behovet for forenkling. I grafikken, som etter hvert også kom til å omfatte litografiet, ser vi en tilsvarende reduksjon av detaljer. Men en ny gjengivelse av naturen handler først og fremst om valg av motiver. Det er her vi kan trekke den sterkeste forbindelsen mellom Werenskiolds grafikk og Cézanne. Dette temaet utdypes i kapittel 3.

\section{Streken som uttrykksmiddel}

Raderingene blir naturlig nok liggende utenfor Werenskiolds utvikling med fokus på det formaltekniske i maleriet på denne tiden. Raderingene ble til som et resultat av møtet mellom de grafiske kvalitetene og de maleriske mulighetene i motivene. De grafiske kvalitetene ses i motivenes kontrastrike utforming.

Kontrasten mellom lyse flater og mørke figurer kommer fint fram i Gutt som binder på seg skiene (1913). Fastheten i den lille, mørke, konsentrerte skikkelsen blir forsterket av det store lyse, snødekte området omkring, definert av det hvite i arket. Den samme grafiske kontrasten utnyttes i Smågran og furustammer (1914), og i den sinnrike modelleringen av trærne i Tilsnødd skog (1911). I andre raderinger er det en større nyanserikdom, som for eksempel i Skygger over Flyen (1913) hvor fjellsidenes uregelmessige struktur gis en kraftig lys- og skyggevirkning. Strekføringen i raderingene gir formale variasjoner og spenner fra det faste og kontrastfylte og over i et nærmest impresjonistisk, vibrerende inntrykk slik som i Bjørkene ved jernbanelinjen (1910).

I raderingene kunne Werenskiolds ønske om rasjonalisering med virkemidlene komme til sin rett på en annen måte enn i maleriet. Fargen er eliminert og de stramme formene forsterkes med den etsede strekens kraftfulle og spesielle karakter, og harmonerer med Werenskiolds gehør for «større forenkling og mer afveiet komposition». ${ }^{46}$ Den etsede linjen er like unik som oljemaleriets penselstrøk, og til sammenligning svært forskjellig fra den mer sirlige blyant- eller penne-streken. I raderingene veksler Werenskiold mellom å bruke spontane, korte, tilsynelatende raskt tegnede spor i etsegrunnen, noe som gir et inntrykk av bevegelse eller uro, og å bruke mer planlagte, kontrollerte, lengre linjer satt på platen i tilnærmede paralleller eller krysskraveringer, noe som skaper mer ro og fasthet. På denne måten brukte han både sin tidlige impresjonistiske tendens og sitt senere behov for forenkling av formene. Med skraveringsteknikken fikk Werenskiold fram nyansene i gråtoneskalaen.

Innenfor etsningens gitte rammer, begrenset av materialer og prosesser, gjenskapte Werenskiold naturen og uttrykte ideer og følelser. I boken Visual Communication and the Graphic Arts tar Estelle Jussim opp de enkelte grafiske medienes muligheter og begrensninger. Selv om etsningsrenessansens ildsjeler framhevet etsningens fortreffelighet som «autografisk» og «fritt» medium, har etsningen sine klare begrensninger som bestemmer lesingen av bildeflatens linjer. «[...], pure line etching usually represent forms by a) direction of line to create contour; b) blank, or white areas, outlined with varying thickness of line and placed against massed lines which stand for midtones; c) a kind of aerial perspective [...]: that the thinner of two lines placed side by side will appear further away, as the eye tends to interpret smaller objects as being more 


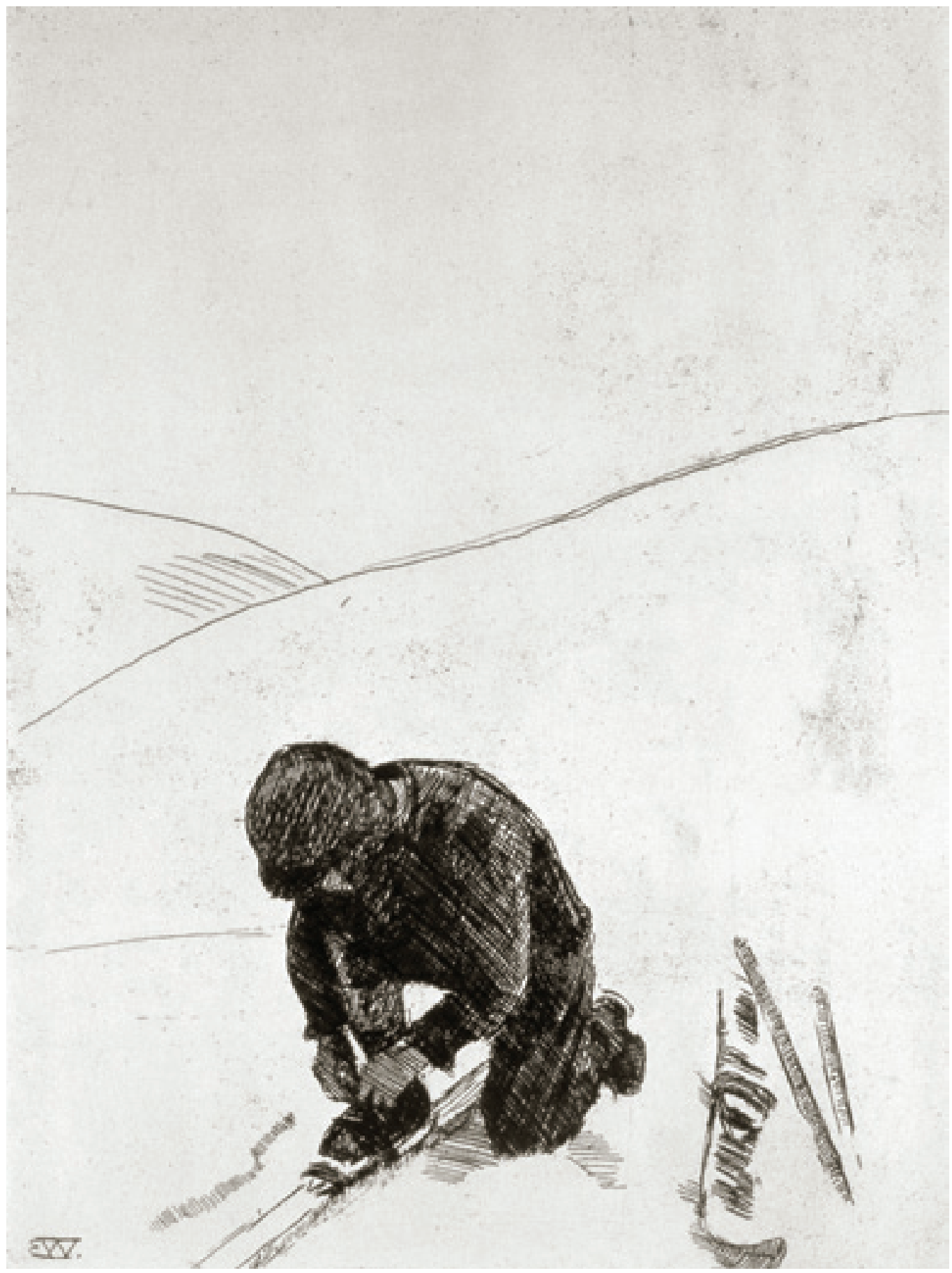

Gutt som binder på seg skiene, 1913. Streketsning (Kat.nr. 35) 


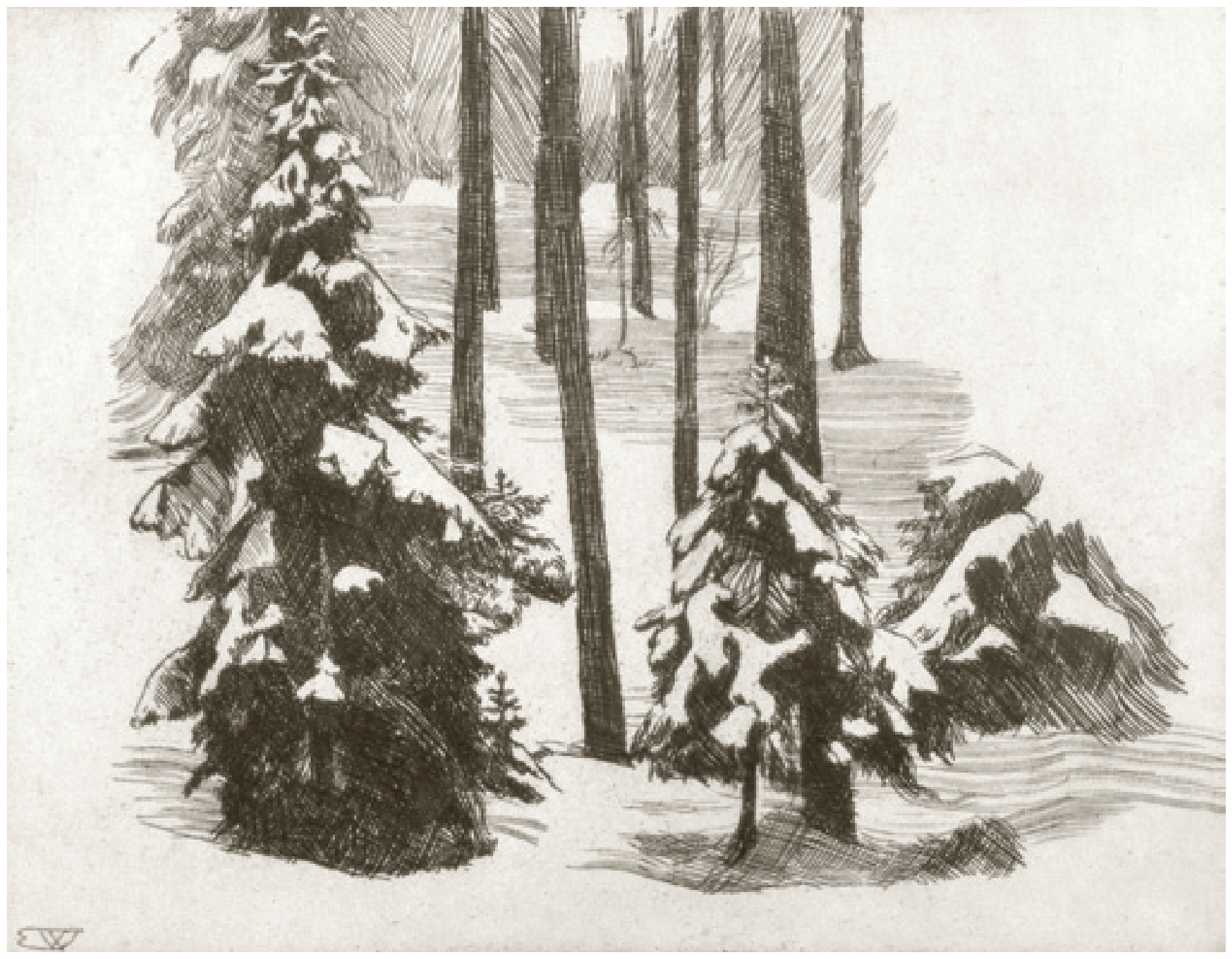

Smågran og furustammer, 1914. Streketsning (Kat.nr. 56)

distant from it than larger objects; and (d) black masses placed against paler tones, or against pale outline structures, so the darker object tends to be interpreted as being closer to the eye than the lighter objects, especially if the principal of overlapping planes is used. [...] No matter how «free» and autographic line etching was, [...], the medium had its distinct limitations for autographic statements about three-dimensional objects.»47 


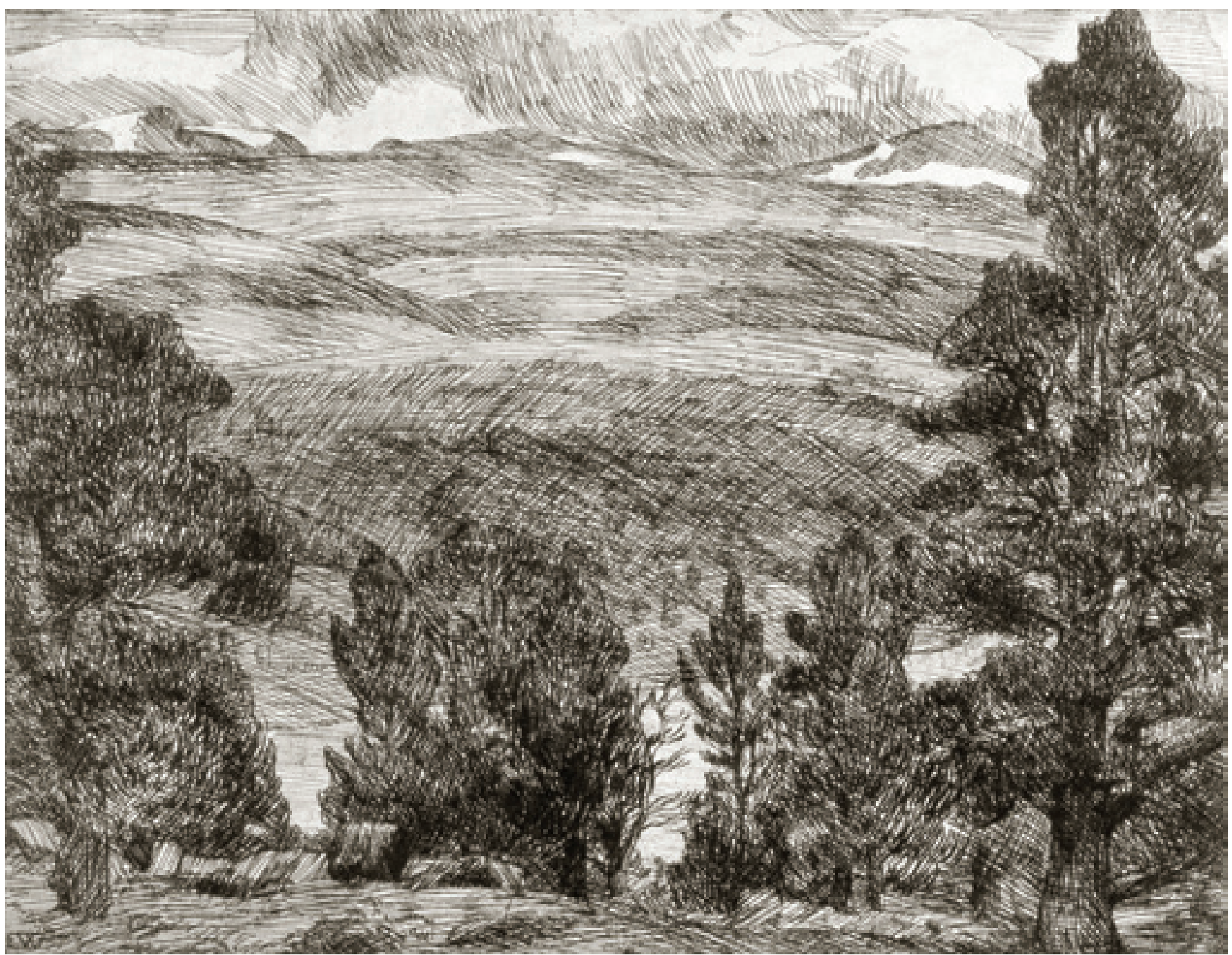

Skygger over Flyen, 1913. Streketsning (Kat.nr. 45)

Erik Werenskiolds etsninger er en kombinasjon av fri tegning og systematisk linjeføring. Den mer systematiske linjeføringen kommer fram der hvor han bruker krysskravering eller tilnærmet parallelle linjer. Werenskiold utnyttet disse to linjeføringene til forskjellige formål. Hele tiden er det de kryssende linjene som framstår som mørkest i bildeflaten. Han bruker dem for å oversette mørke og lyse farger til svart-hvitt, for å lage skygger som modellerer figurer og landskap, og for å gradere plasseringen av figurer innover i bilderommet.

Et eksempel på gjengivelse av lyse og mørke farger kan være raderingen Hånd $i$ hånd (1913). I pikens ullkåpe til venstre i bildet har Werenskiold brukt krysskravering som gir en mørkere valør enn den parallelle linjeføringen i kåpen til høyre. 


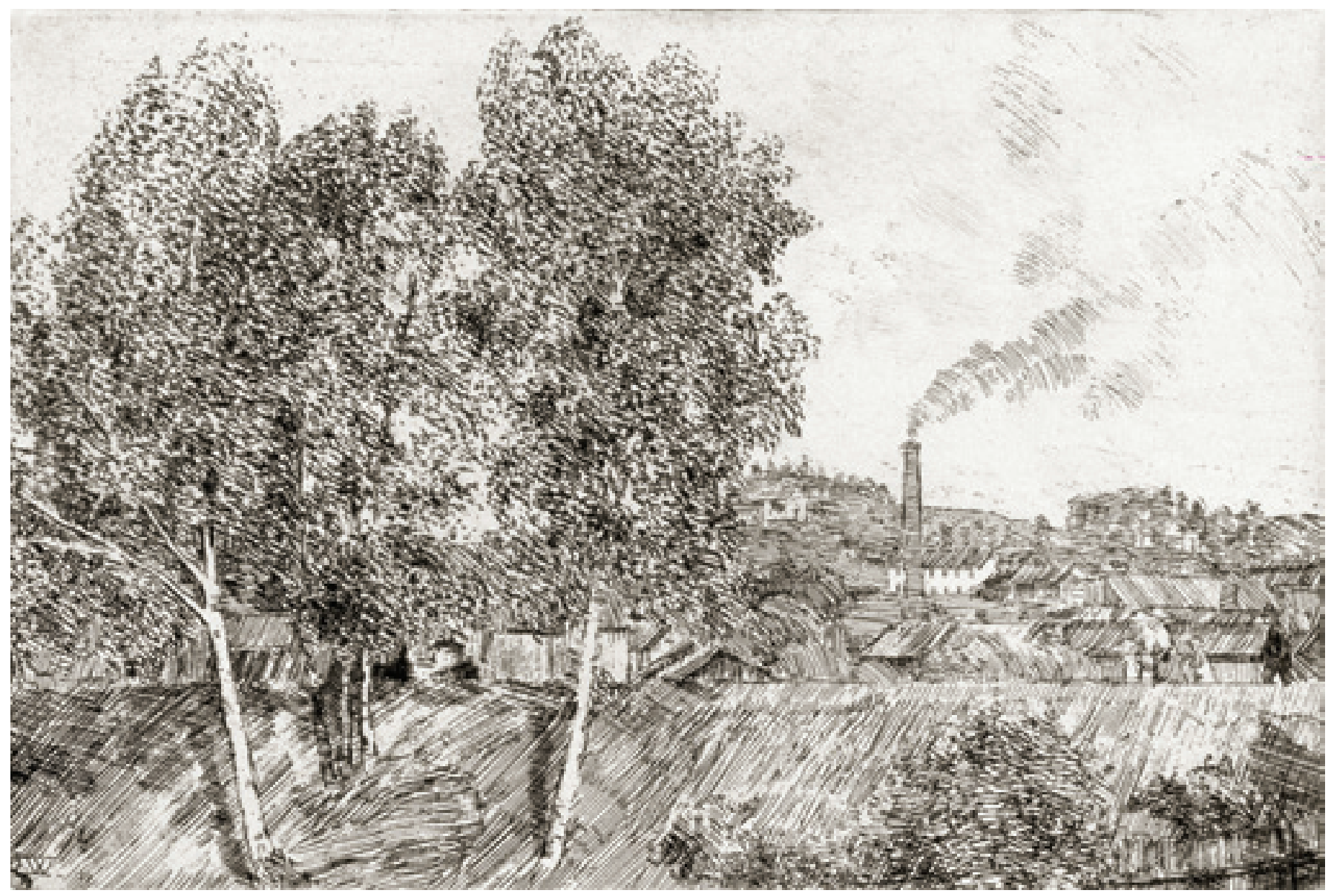

Bjørkene ved jernbanelinjen, 1910. Streketsning (Kat.nr. 22)

Her er ikke den lyse og den mørke flaten brukt for å plassere den ene figuren lenger fram i bildeflaten enn den andre, men for å fortelle at den ene kåpen er lysere enn den andre. Begge figurene er plassert i bildeflatens forgrunn. Når det gjelder skyggevirkninger, kan de ses i brospennets buer i raderingene Lysakerbrua, vinter (1908-1909) og Kullsjau (1909), og skyggenes modellerende hensikt kommer fint fram i portrettet Hans E. Kinck (1914). I To gutter (1909) får figuren til venstre i bildet tydeliggjort sin plassering lengst fram i bildeplanet, ikke bare ved hjelp av størrelsesforholdet til den mindre figuren, men også gjennom krysskraveringens mørke valør.

Den friere streken, den systematiske linjeføringen og de rene flatene kombineres på en fruktbar og uanstrengt måte også i de to etsningene Steinfinsbø (1913) og Sjoa og Steinfinsbø (1913). Den frie streken ses i den varierte framstillingen av trær og annen vegetasjon, mens husene og åskammene har fått en fastere oppbygging med systematiske, tilnærmet 


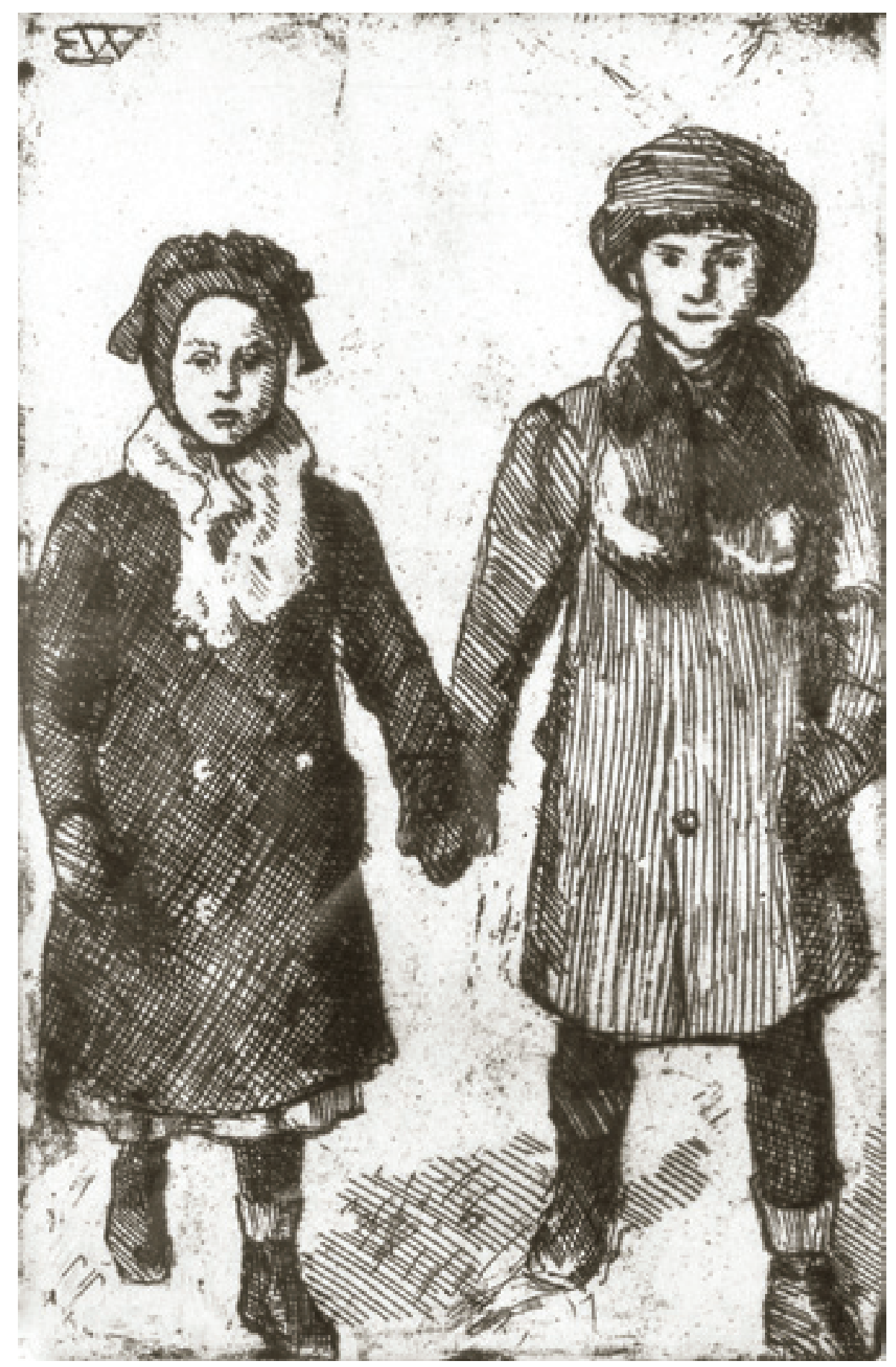

Hånd i hånd, 1913. Streketsning (Kat.nr. 38) 


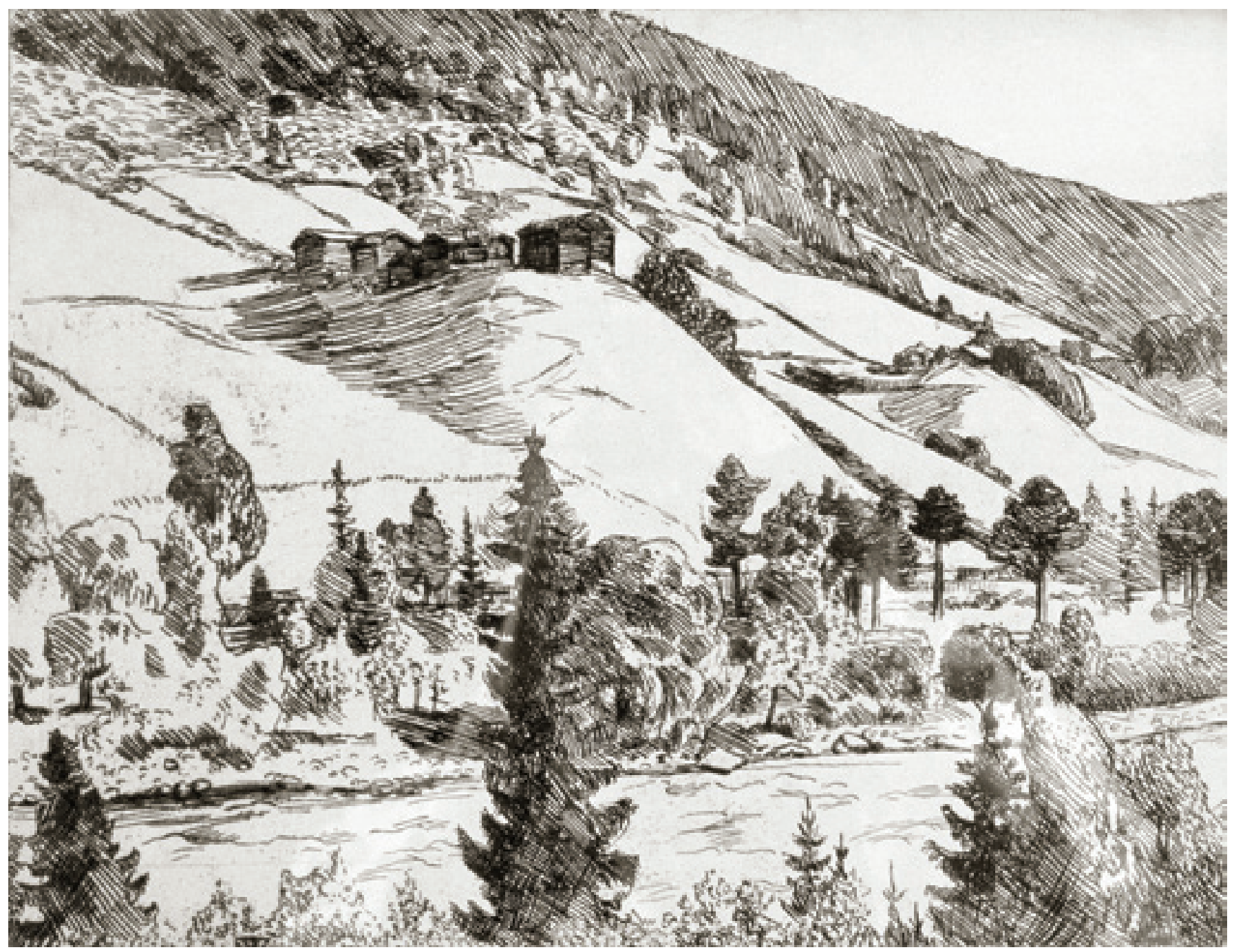

Sjoa og Steinfinsbø, 1913. Streketsning (Kat.nr. 43)

parallelle streklag. Gårdens åkerlapper og enger ses som lyse områder i den bratte skråningen, tegnet med streker i varierende tykkelse plassert mot mer samlede linjer som gir felt i grå mellomtoner.

Naturalismens affinitet til fotografiet er poengtert i den kunsthistoriske litteraturen, og Werenskiolds grafikk kan ikke unntas fra denne forbindelsen. Første forsøk (1904) har en motivstørrelse som tilsvarer et fotoformat som på 1870-tallet ble introdusert i Norge som «cabinettformatet». ${ }^{8} \mathrm{Ut}$ fra dette er det ikke urimelig å anta at Werenskiold kan ha brukt fotografi

48 Erlandsen, Pas nu paa! Nu tar jeg fra Hullet!, 105. 
som støtte eller direkte forlegg til sin første radering. Fotografiske forlegg kan også ha vært i bruk i de to neste raderingene, Båter under Lysakerbrua (1908-1909) og Lysakerelva (1908-1909), som har det konsise i lys- og skyggevirkninger som lett assosieres med fotografiets. De har også en bemerkelsesverdig stødig utførelse, tatt i betraktning at de hører hjemme så tidlig i produksjonsrekken. Etter stadig gjennomgang av bildematerialet framstår de tre første raderingene som noe annerledes i sin formale karakter enn de neste. De som følger gir et annet, friere og mer spontant inntrykk.

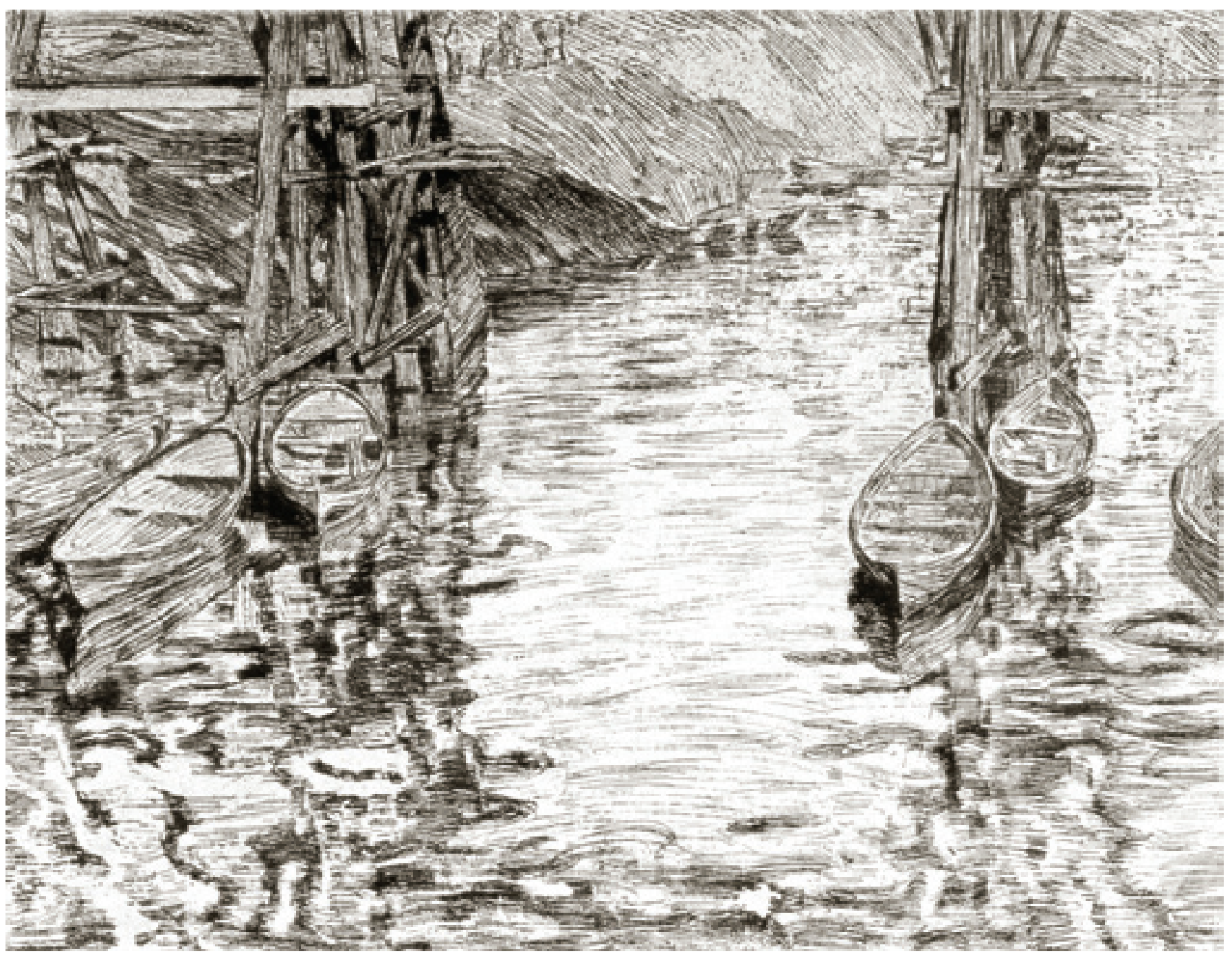

Båter under Lysakerbrua, 1908-1909. Streketsning (Kat.nr. 2) 
Antydningen om at Werenskiold kan ha brukt fotografier som støtte eller inspirasjon til sine første raderinger, innebærer ikke at han er på kollisjonskurs med den omtalte etsningsrenessansens opposisjon mot dette mediet. Å forholde seg til virkeligheten inkluderte også fotografiske gjengivelser. Fotografiets troverdighet som dokumentarisk kilde ble tidlig etablert, og siden stadig diskutert. Til tross for mange kunstneres forsiktige bruk av og ambivalente innstilling til fotografiet, var anvendelsen av det som forlegg, inspirasjon eller «skisse» et faktum. For Werenskiolds del kan det se ut til at hans forhold til fotografiet kan sammenlignes med Linda Noclins betraktninger rundt Degas' måte å bruke mediet på: «Degas, more than any other Realist, looked upon the photograph not merely as a means of documentation, but rather as an inspiration: it evoked the spirit of his own imagery of the spontaneous, the fragmentary and the immediate». ${ }^{49}$ Ingen kan med sikkerhet vite i hvor stor grad fotografiet har hatt innvirkning på forskjellige kunstneres verk, men en betydning har det hatt. Utendørsfotografier tatt i sterkt sollys framhever de store kontrastene mellom belyste og skyggelagte deler av motivet. Den samme virkningen kan oppnås i portrettfotografier tatt innendørs med eksperimentell bruk av studioblitz. Et eksempel på det siste kan være Manets Portrett av Charles Baudelaire (1865), hvor forlegget er Nadars fotografi av den franske forfatteren fra $1859 .{ }^{50}$ Her fører Manet de sterke kontrastene mellom lys og skygge hos Nadar over i etsningen hvor han utnytter det hvite i arket som høylys, og skraverer med tette streklag i de mørke partiene. Et annet eksempel fra mer hjemlige forhold kan være Christian Krohgs forlegg til Albertine i politilegens ventevcerelse (ca. 1884). Krohg brukte fotografiet blant annet til studier av kompositoriske trekk og i noen tilfeller også som direkte underlag for bemaling. ${ }^{51}$ Edvard Munch «benyttet [...] hele sitt liv i en eller annen forstand fotografiet i sin kunsts tjeneste, det være seg som støtte for sine portretter eller som inspirasjon til et nytt syn på gjengivelsen av virkeligheten». ${ }^{52}$ Et eksempel er fotografiet av modellen Rosa Meissner tatt i Hotel Rôhne i Warnemünde i 1907. ${ }^{53}$ Meissners positur kjennes igjen i litografiet Gråtende akt (1907), mens både figur og rom er gjengitt i de to litografiene Gråtende ung kvinne ved sengen (1930), det ene er i svart-hvitt, det andre i farger. I andre halvdel av det 19. århundre og begynnelsen av det 20. finnes det utallige eksempler på denne utvekslingen av formal informasjon mellom fotografi og grafikk eller maleri.

\section{Det dekorative}

En helt annen formal løsning er valgt i komposisjonen Saga I (1918?). I dette motivet ligger forbindelsen til middelalderens rytmiske og faste oppbygning av dekorative flater: To hester er stilt opp mot hverandre i forgrunnen. De holdes i tøylen av en mannsfigur som er stilt opp mellom dem. To menn i brynje og hjelm til venstre og høyre i bildeplanet står henholdsvis foran og bak de stiliserte hestene. Et nettverk av greiner med løv på fyller bakgrunnen. I den grad Werenskiold gjorde bruk av stilisering med utgangspunkt i naturens former, gikk han aldri ut over figurens grunnform. Formene viser alltid en

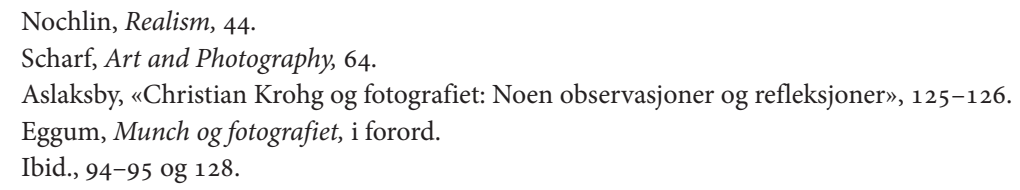




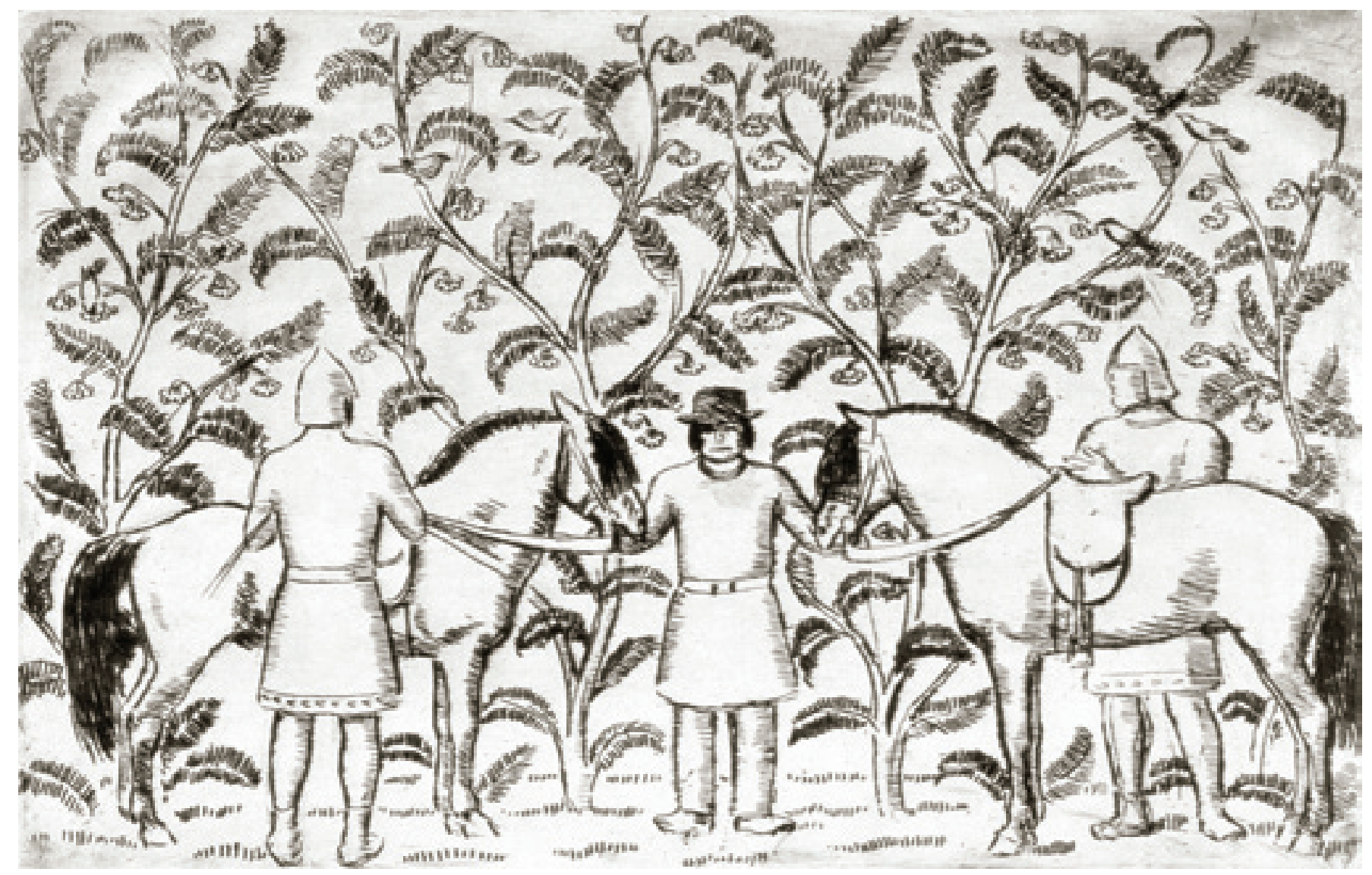

Saga I, 1918?. Streketsning (Kat.nr. 83)

utvetydig realistisk forbindelse, slik at bildespråket fortsatt leses som kjente tegn. Saga er et eksempel på at Werenskiold gjorde bruk av dekorative kvaliteter også i grafikken.

Tone Skedsmo skriver $\mathrm{i}$ «Kunst for alle, kunst $\mathrm{i}$ alt» at Werenskiold «med sin realistiske grunnholdning så på det dekorative i en videre betydning og derfor kanskje opplevde kunstverkets dekorative side som en problematisk utfordring»".54

I den tidstypiske debatten på overgangen mellom 1800- og 1900-tallet var «det dekorative» under stadig behandling. Diskusjonen var rik på nyanser, og i sin artikkel «Norsk kunstdebatt ved modernismens terskel» tar Magne Malmanger for seg en rekke av ytringene. Under avsnittet «Fra subjektiv uttrykksform til objektiv norm» skriver han: «I Werenskiolds strenge og rasjonelle sinn festet det dekorative seg [...] ikke bare som et ordnende, men som et overordnet formalt prinsipp. Dermed ble det nær knyttet til den tegningens disiplin som behersker hans eget kunstneriske virke, enten vi nå tenker på

54 Skedsmo, «Kunst for alle: Kunst i alt», 12. 
den presise beskrivelsen av den enkelte form eller på den komposisjonelle organisasjonen av bildet som helhet. [...] I løpet av 1890-årene forandret Werenskiolds kunst seg i retning av forenkling og formal tilstramming, og denne tendens ble bare forsterket etter århundreskiftet. Den kom [...] klarest til syne i arbeider av utpreget dekorativ art. [...] Staffelibildene gjennomløp en lignende forandring, men det var først omkring 1909 den gjorde seg gjeldende med samme styrke som i de dekorative arbeidene. [...] [Werenskiold] gikk ut fra en naturalistisk fremstillingsmåte, for så gradvis å modifisere sitt formspråk i retning av en forenklet og konsentrert kunst av mer dekorativ karakter.»55

«Det dekorative» kan knyttes til Werenskiolds regelmessig oppbygde flatekunst med stiliserte naturformer, og kan ut fra kompositoriske trekk skilles fra hans naturalistiske komposisjoner etter 1900. I den dekorative flatekunsten er de enkelte elementene hele tiden gjenkjennelige som naturformer i rytmisk, regelmessig plassering over bildeflaten. Selv om elementene i de naturalistiske bildene får en strammere form, påvirker det ikke bildeflatens komposisjonelle organisering. Den harmonien som etterstrebes her, er mer å anse som en konstant faktor i Werenskiolds bildeproduksjon generelt. «Jeg morer mig med at gjennemarbeide mine saker så de blir riktig solide, men samtidig ser jeg sterkt på forenkling, komposition, linievirkning, og selvsagt på farven.» $\aleph^{56}$

At Erik Werenskiold skiller mellom det dekorative og det naturalistiske som formal løsning, kommer fram i en kommentar til noen av Henrik Sørensens malerier: «Han er «åndfull», fantasirik, maler «vision» og «drøm» og «Inferno» og sågar en Kristus på korset. Disse to siste store billeder var nu ikke goe. I det hele tat mangler der litt rum og fast bygning $\mathrm{i}$ hans ting, men han er følsom, har tegnet meget og det er alltid interessante ting, sommetider ganske nydelige ting $\mathrm{i}$ hans billeder, skjønt få er virkelig helstøpt. Ja, noen; men han svæver midt imellom naturalisme og dekoration.»57

Synspunktene knyttet til formspråk var sterke hos Werenskiold, og ble etter hvert som han søkte til de mer forenklede formene i maleriet, ytterligere poengtert. Ifølge Werenskiold ligger hele bildets formidlingsevne nedfelt i komposisjonens formale løsning. «Som naar Degas maler sine danserinder pa scenen og foran dem bare hoderne paa tilskuerne - hode ved hode, tæt pakket; eller naar de Nittis i et av sine billeder fra veddeløpene gjør en tribune med et elegant publikum helt fremme i rammekanten til venstre, og saa en vid utsigt med en vrimmel av mennesker hele veien ned igjennem og utover sletten, mindre og mindre jo længere de kommer bort, intil de tilslutt blir bitte, bitte smaa med opslaatte paraplyer længst ute, hvor der gaar en regnskur; eller et andet sted et selskap med herrer og damer som varmer sig om et kulbækken, hvor hele forgrunden er optatt av tomme kurvstoler; - alt dette er jeg fuldkommen med paa: det er fortællende, det skildrer ypperlig, det er nødvendig til situasjonens karakteristikk; det ser godt ut, er pikant og originalt, og gjør slet ikke indtryk av at være søkt, fordi det er saa naturlig..» ${ }^{8}$

Med friheten til å utvikle sitt eget uttrykk i form av etsninger, kunne Erik Werenskiold skape en for ham særegen «linjesyntaks». Etsningsrenessansens store fortjeneste var at den frie etsekunsten kunne åpne opp for de subjektive og kunstnerisk kreative kvaliteter og gi grafikk i vid forstand status som autonom kunst knyttet til et medium som ble assosiert med en demokratiserende intensjon ut fra muligheten til mangfoldiggjøring.

55 Malmanger, «Norsk kunstdebatt ved modernismens terskel», 35.

56 Brev fra EW til BG datert 9.9. 1919.

57 Brev fra EW til BG datert 12.11. 1921.

58 Werenskiold: «Impressionisterne», 66. 


\section{Det nye århundre}

Erik Werenskiolds 1900-tallskunst kan tolkes på forskjellige måter. For noen motivers del kan vi fortsatt velge å se dem i sammenheng med 1800-tallsnaturalismen. Slik sett vil de framstå som representanter for en nasjonalt orientert kunst med et innhold som kan leses som en form for nasjonal fortelling. Men det er et faktum at Werenskiold på begynnelsen av 1900-tallet ønsket seg bort fra dette. Særlig ble dette tydelig etter møtet med Paul Cézannes kunst i 1908. Utfordringen for oss som betraktere blir å fristille noen av motivene fra 1800-tallets tradisjonelle tolkning, til tross for at han fortsatt tar utgangspunkt i den samme motivkretsen og holder seg til et naturalistisk formspråk. «Det nasjonale i kunsten» slik det ble forstått på 180o-tallet var på mange måter utdatert. I grafikken ser vi hvordan Werenskiold veksler mellom det nye, nøkterne i motivene og det mer romantiserende og stemningsfulle. Vi trekkes unektelig tilbake til 180o-tallet når vi ser motivene fra Heidal og Jotunheim. Mens vi ser konturene av det nye århundre i flere av Lysaker-motivene. Også motiver som Lysakerbrua, vinter (1908-1909), Tank (1914) og Hunelven (1915) kan tjene som eksempler på den nye nøkternheten i de mer uanselige motivene som bringer oss over i en annen estetisk modus.

Forbindelsene til det forrige århundre kom til uttrykk da Werenskiold høsten 1913 oppholdt seg i den østre delen av Jotunheimen. I ni raderinger fra dette året kan vi følge reiseveien gjennom Heidal. Han starter med de to gårdsmotivene Steinfinsbø og Sjoa og Steinfinsbø, og fortsetter med Heidalen med elva. Videre går veien sørvestover hvor Heidalen går over i Sjoadalen. Werenskiold raderte Skygger over Flyen (Hindflyen) og Nautgardstind, og litt lenger sør fant han motivet Aspen ved Besshø og Besshø. Nautgardstind og Besshø trer tydelig fram i landskapet, begge ruver med sine 2258 meter over havet. Fra samme område er raderingen Furuene på Hindseeter. I disse fjelltraktene fant Werenskiold «det mest norske stedet ${ }^{59}$. Her ser vi et innslag av en lett romantiserende tendens. For Werenskiold representerte det tilsynelatende uforanderlige fjelllandskapet i Jotunheimen en konstant faktor som stimulerte følelsen for naturen som alltid kom til å være av betydning for ham. Werenskiolds kunst var ikke en konstruksjon eller en fiktiv forestilling om nasjonal tilhørighet knyttet til naturopplevelser, men en visuell gjengivelse av den alminnelige betrakters oppfatning av fjell, daler og vidder. Besshø og Nautgardstind tjener som gode eksempler på naturalistiske gjengivelser som bekrefter Werenskiolds nå noe nedtonede, men fortsatt levende opptatthet av nasjonale røtter.

Den topografiske bildekunstens framstillinger av lokale forhold «aktualiserte tilhørighet til sted, og begrunnet denne tilhørighet med kulturelle verdier». ${ }^{60}$ Denne oppfatningen var ikke av ny dato. Allerede i andre halvdel av 1700 -tallet fantes det en kulturpolitisk bevegelse med nasjonal dreining. «Det er et søkende og til dels famlende prosjekt, det involverte relativt få mennesker, og det hadde liten gjennomslagskraft i befolkningen. ${ }^{61}{ }^{11}$ Men det finnes, ifølge Olav Christensen, belegg for å si at den nasjonale bevegelsen på begynnelsen av 1900-tallet griper tilbake til denne spede spiren som viste seg å ha sterke og livskraftige røtter. Gjennom topografiske skrifter «ble territoriet Norge styrket både som kunnskapshorisont og som forestilling. [...] [Samtidig var] topografisk litteratur et middel til å prise sin nasjon og sitt hjemsted. Det er en normal foreteelse å knytte følelsesmessige bånd til oppvekststed og lokalmiljø, og dette affektive forholdet kan ved læring utvides til å gjelde

59 Connor, Democratic Visions, 174. Connor benytter uttrykket «The Most American Place».

60 Christensen, «En nasjonal identitet tar form», 61

61 Ibid., 51 


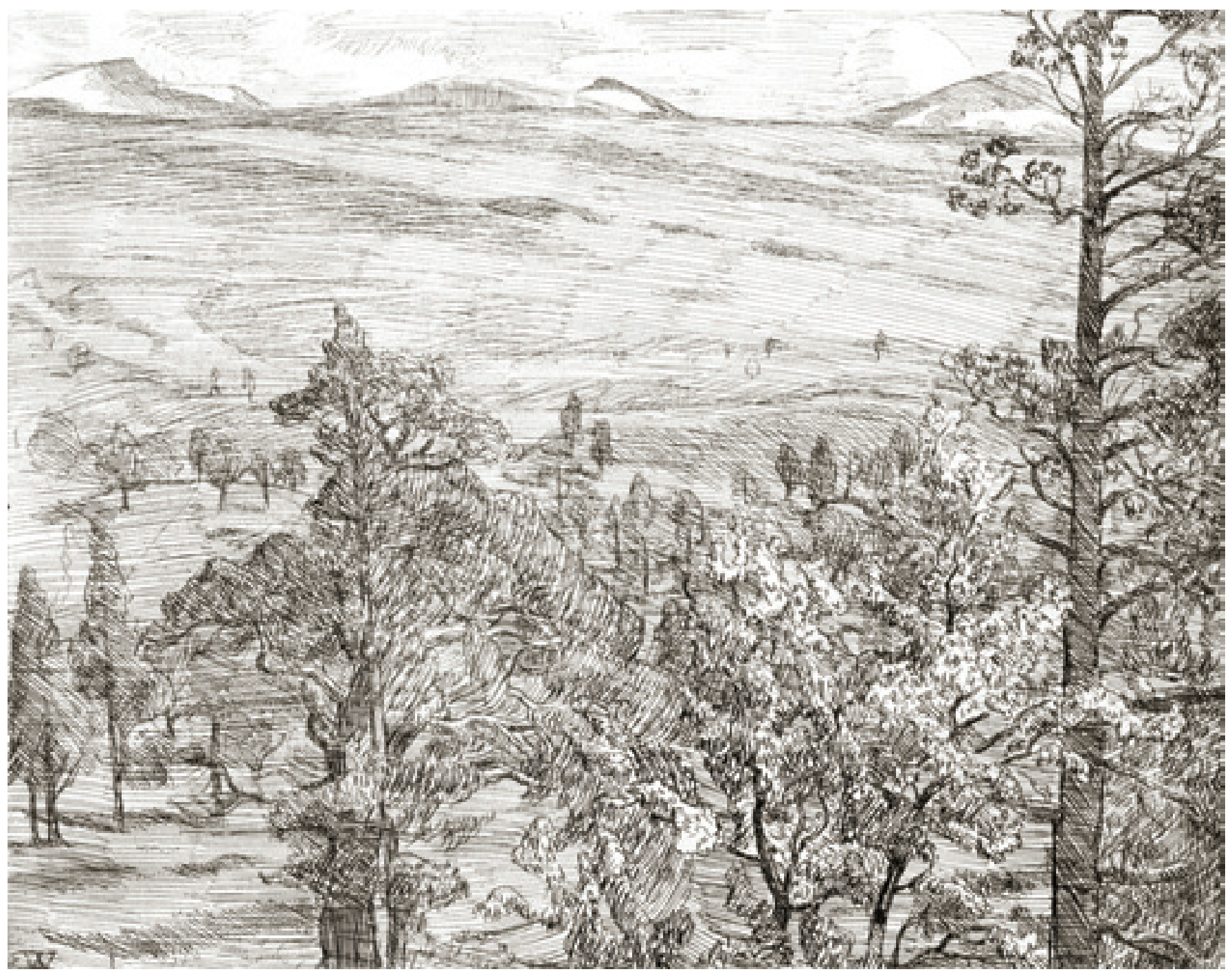

Nautgardstind, 1913. Streketsning (Kat.nr. 46)

større enheter som for eksempel en nasjon. For nordmenns del ble det lettere å elske sitt land etter at vill (fjell-)natur ble oppvurdert som landskapstype gjennom hyrderomantikken og rousseauismen. ${ }^{62}$ Nils Messel skriver «I oppdagelsen av fjellet» blant annet om Flintoe og Carpelan, som i 1819 begge var med på å etablere et merkeår i norsk kunst da de foretok sine første store reiser i den norske fjellheimen ${ }^{63}$ Fra plansjeverk fra 1780 -årene, via Flintoe og Carpelan og nasjonalromantikerne

62 Ibid., 60-61.

63 Messel, «Da fjellet ble oppdaget», 10. 


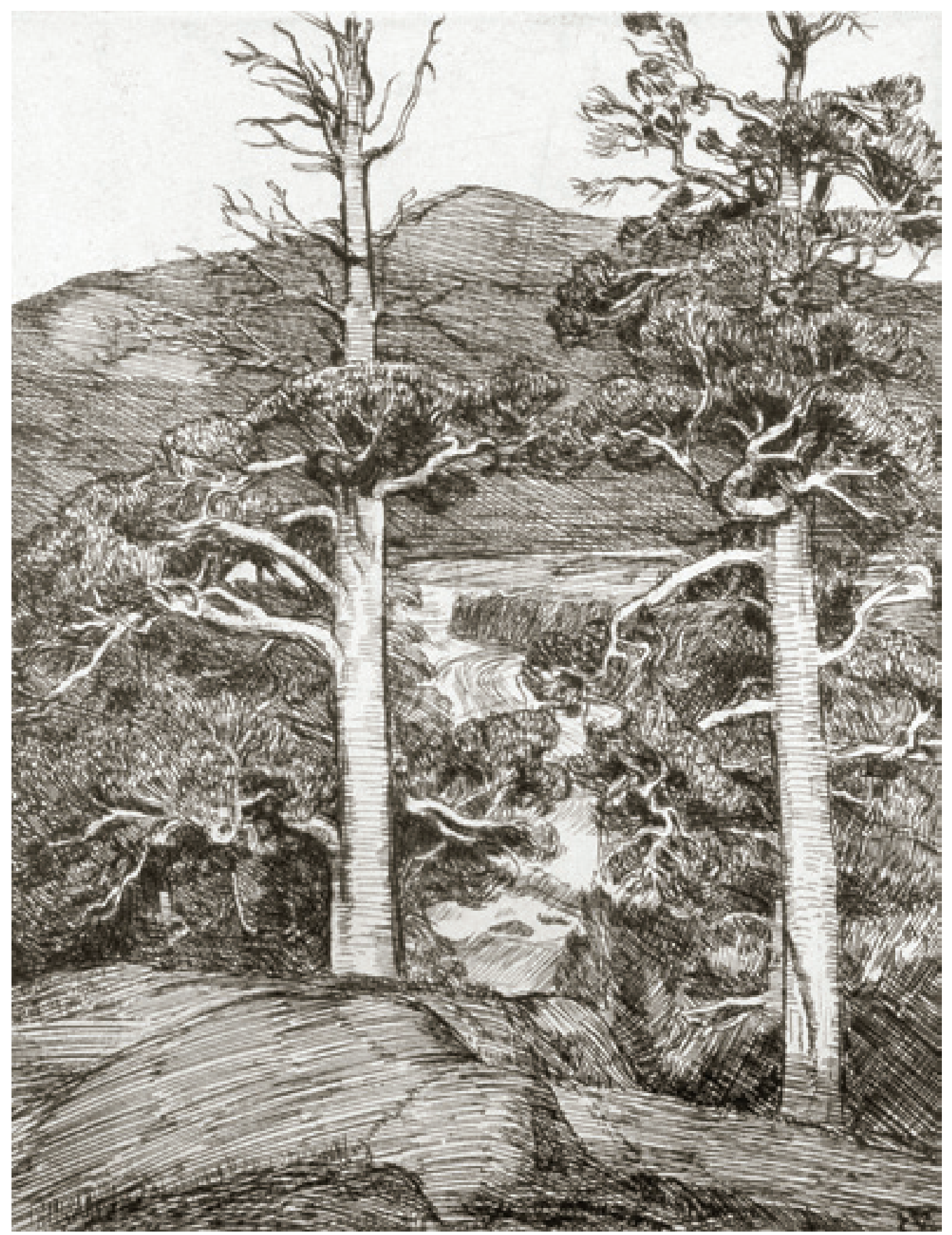

Furuene på Hindsæter, 1913. Streketsning (Kat.nr. 50) 


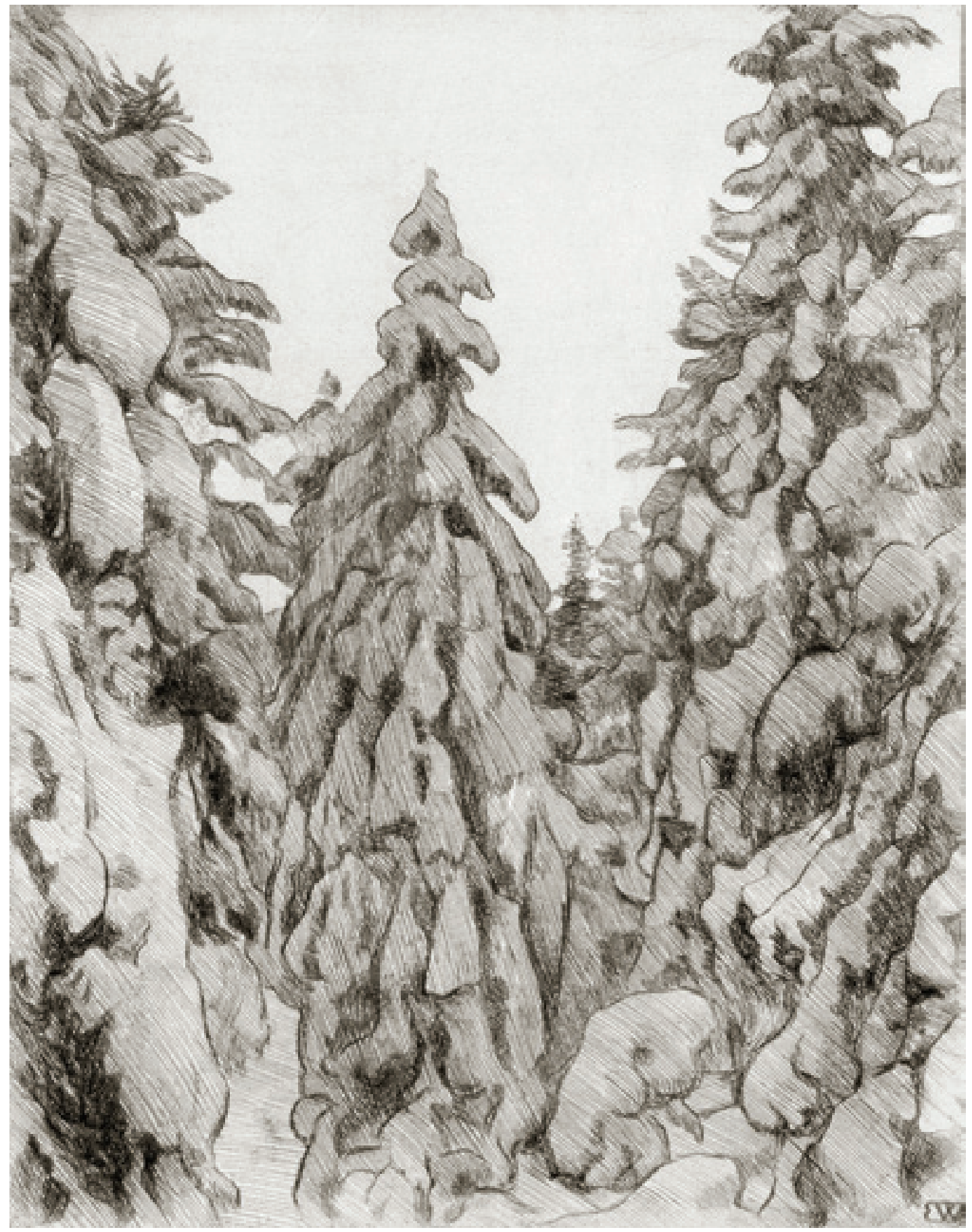

Tilsnødd skog, 1911. Streketsning (Kat.nr. 27) 
og fram til begynnelsen av 1900-tallet går det en rød tråd. Hensikten med gjengivelsene og uttrykkene i seg selv varierte. Men felles for forskere og kunstnere er at de lot fjellet representere seg selv. «De var først og fremt interessert [...] i fjellet slik det viste seg for ens øye.. ${ }^{64}$

Nordmenn fikk gjennom bilder og skrift sin etniske tilknytning til fjellet. Dessuten ble denne tidens syn på det kalde klimaets foredlende virkning opphavet til den norske vinteridealiseringen. I Werenskiolds grafikk blir vekslingen mellom det lokale og det regionale til en visualisert refleksjon over nasjonal og kulturell identitet. Motiver som understreker Werenskiolds folkelige appell, og gjengivelse av motiver som trekker veksler på den kalde årstidens foredlende virkning, ser vi blant annet i motiver med barn som går på ski. Motivene har også relevans i forhold til det demokratiske kriteriet som forbindes med fellesskapets allerede eksisterende virkelighetsoppfatning og felles identitetsforståelse.

I tillegg til vinterlige fritidsaktiviteter, er det en utbredt tolkning i kunst- og kulturhistorien å se treet som et identitetsbekreftende symbol. Gran og furu forbindes med det skandinaviske, like mye som eiketreet assosieres med det tyske og lønnen med det canadiske. Grantrær med snø forsterker det nordiske aspektet. Tilsnødd skog (1911) er et klassisk symbol på forholdet mellom natur og kultur. Raderingen bringer betrakteren tett på og midt inn i en snøtung, tettvokst granskog. Så å si hele komposisjonen fylles av vegetasjon. Den rene hvite himmelranden deles av en høyreist gran som ruver som en hvitkledd kjempe midt i bildeplanet. Et organisk og intrikat mønster deler opp bildeflaten, og Werenskiolds mesterlige håndtering av lyse og mørke partier får fram det mørke i greinene mot den hvite snøen. Naturens materialitet, tettheten og tyngden i greinene, gjenkjennes, og er et årlig tilbakevendende fenomen som framkaller følelsen av en nasjonal, nærmest lyrisk stemning og kulturhistorisk kontinuitet. Vintermotivene handler om identitet, men kan også tolkes ut fra formale kriterier og viser Werenskiolds evne til å gjengi snøens rent estetiske verdi.

\section{Vinter og ideen om sunnhet}

Werenskiolds intensjon om å tegne direkte på platen etter naturen, førte til at han ville tegne i etsegrunnen utendørs også om vinteren. De første forsøkene på å tegne i kuldegrader om vinteren var mislykkede. I begynnelsen hadde etsegrunnen en tendens til å flise seg opp eller gå av i flak. Etter hvert fant han fram til en grundering av platene som fungerte tilfredsstillende. Noe av problemet ble løst ved at han blandet litt mer fett i grunderingen, men ikke mer enn at platene fortsatt kunne fraktes uten å ta skade. I tillegg fikk han laget en spesiell innretning: en liten kasse av blikk som han kunne plassere en [olje-]lampe inni slik at etsegrunnen ikke stivnet i kulden. Temperaturen regulerte han ved å legge papp-plater mellom kassen og kobberplaten. ${ }^{65}$ "Jeg vil nemlig radere skiløpere, vinter, og slikt, her nede ved Lysaker er det masser av motiver med barna nede i bakken.» ${ }^{66}$ Et slikt motiv er Gutter på ski (1912). To gutter med sekk på ryggen, i datidens solide skiutstyr har stoppet opp på en bakketopp. Guttene er plassert helt framme i bildeplanet. De mørke figurene ses mot de store trærne i bakgrunnen, og bakketoppen avgrenses med en svak diagonal som stiger fra venstre bildekant mot høyre. Gutten til venstre ses forfra og henvender seg med et spørrende blikk mot gutten til høyre, som ses i profil. Gjennom sin

64 Ibid., 10.

65 Brev fra EW til BG datert 15.3. 1909.

66 Brev fra EW til BG datert 15.3. 1909. 


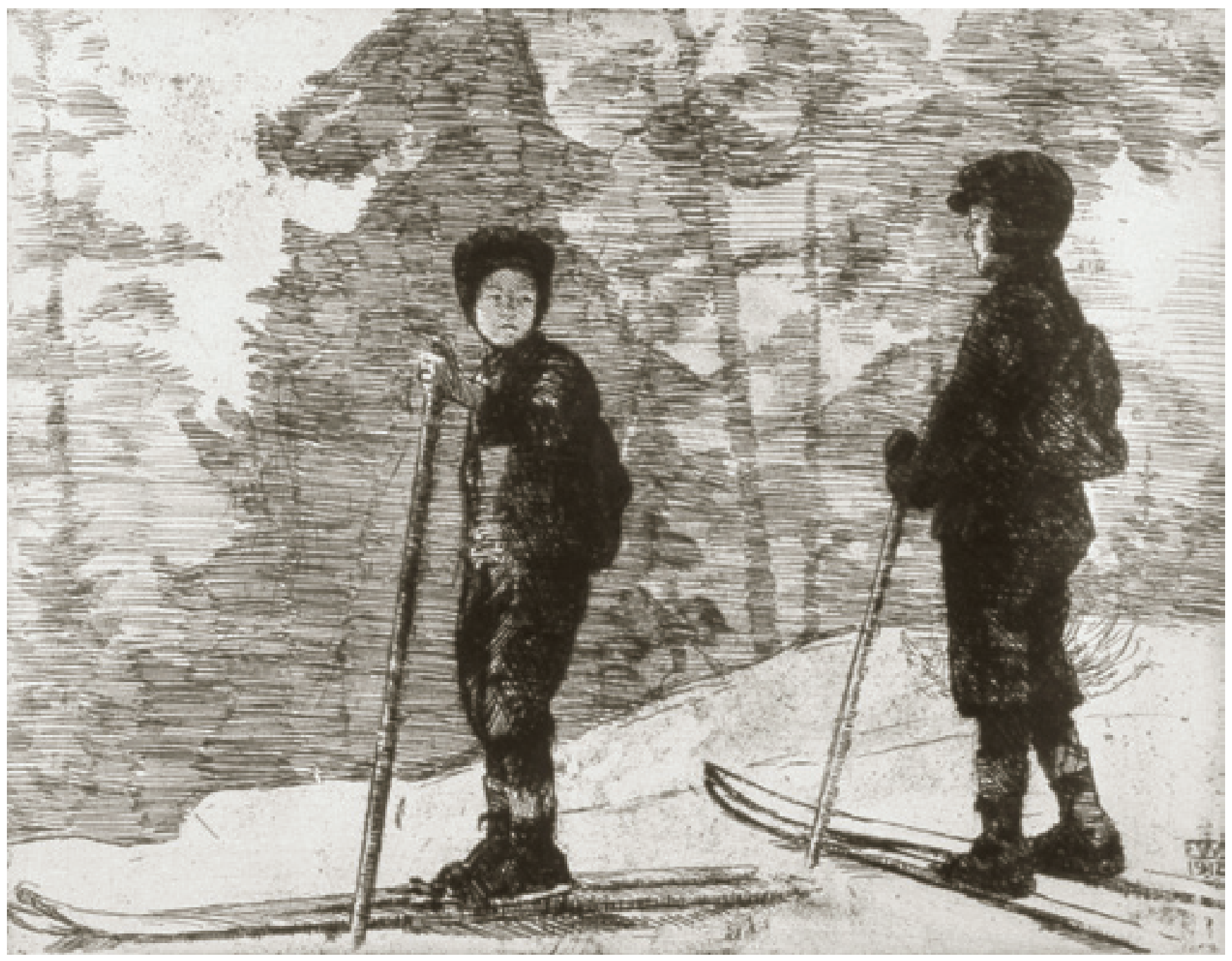

Gutter på ski, 1912. Steketsning. (Kat.nr. 33)

observasjonsevne og psykologiske innlevelse beskriver Werenskiold kommunikasjonen mellom de to figurene. Den ene er litt reservert i kroppsspråket, den andre mer sikker. Gutter på ski bekrefter en fysisk erfaring knyttet til det sunne, friske livet og naturopplevelsen.

Organisert eller uorganisert idrett spilte en rolle i en norsk identitet mot slutten av det 19. og begynnelsen av det 20. århundre. Tilhengere av idrett som fenomen tilla skisporten en spesiell betydning som folkelig kulturuttrykk. Werenskiolds nære venn Fridtjof Nansen var en av idrettens sterkeste talsmenn på denne tiden. Andre i Werenskiolds bekjentskapskrets, 


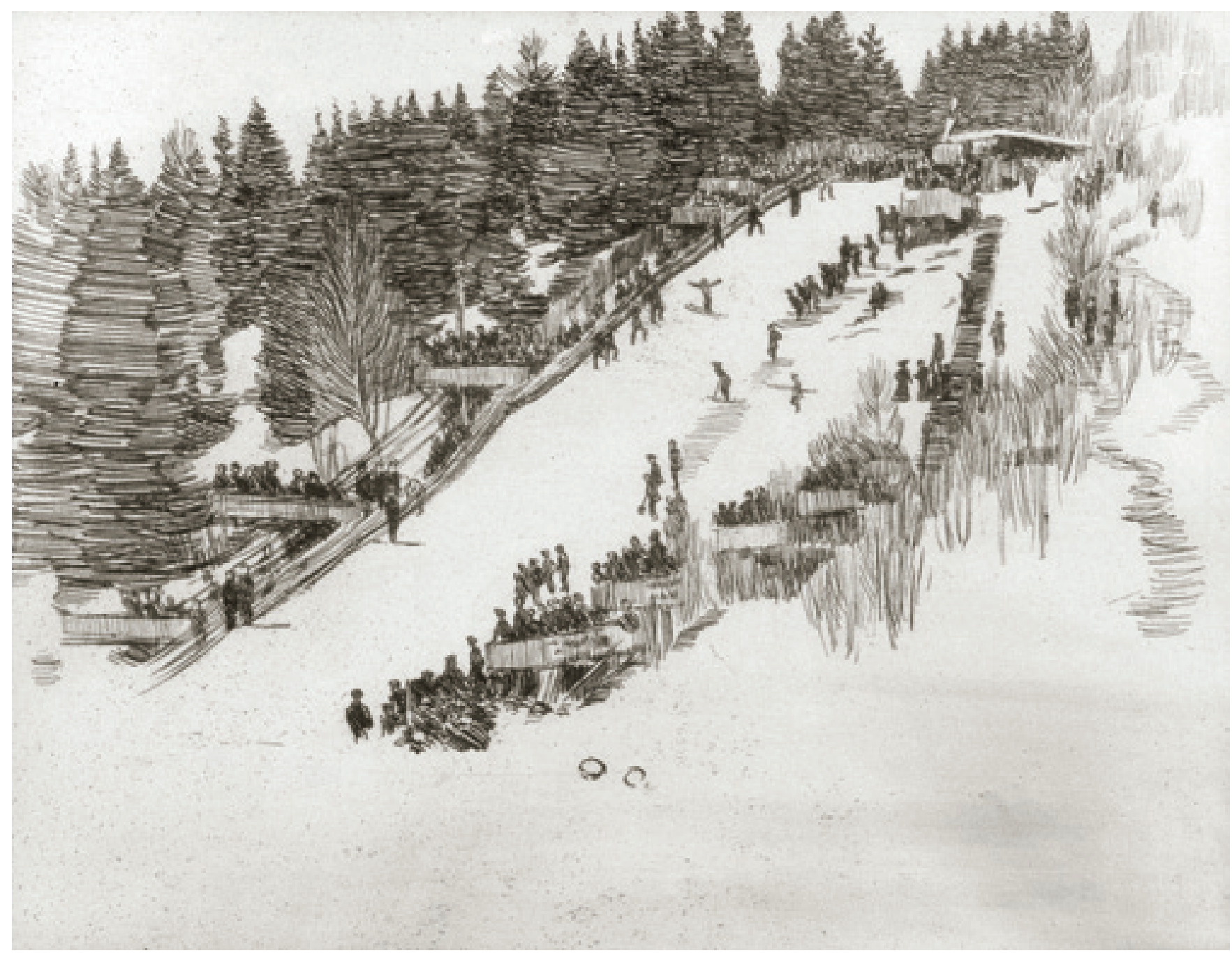

Solbergløpet, 1914. Streketsning. (Kat.nr. 55)

blant dem forretningsmannen Axel Heiberg, var i samtiden kjent for den støtten de ga norsk idrett. Med bakgrunn i de store samfunnsendringene, industrialisering og urbanisering, økte framveksten av organisasjonssamfunnet basert på frivillighet og særinteresser. Idretten ble også omfattet av denne utviklingen, og mot slutten av 1800-tallet «fremsto idretten i tilnærmet «moderne» form, forstått som en institusjonalisert virksomhet sentrert rundt trening og konkurranser i regi av lag og forbund». ${ }^{67}$

67 Goksøyr, «Idretten og det norske: aktivitet som identitet», 159. 
Solbergløpet (1913) viser en av den organiserte skiidrettens arenaer. Det sentrale i raderingen er unnarennet på en hoppbakke med en skihopper i svevet. Bakken er omkranset av en mengde tilskuere som befinner seg i avsatser på begge sider. Hoppkanten er plassert i øvre høyre hjørne av motivet, unnarennet går som en diagonal over bildeplanet og skråner ned mot venstre. En skogkledd åsside følger bakkens skråning. Werenskiold gjengir her Solbergbakken i Bærum. På slutten av 1800- og langt inn på 1900-tallet var dette et samlingssted for skihoppere både lokalt og nasjonalt. Her arrangerte Bærum skiklub [sic.] årlige renn, og hele landets hoppelite var til stede. Bare Holmenkollrennet hadde på denne tiden større oppslutning og høyere prestisje enn Solbergrennet her til lands. ${ }^{68}$

Idretten som bred folkelig bevegelse hadde sin opprinnelse i en sped begynnelse i forbindelse med feiring av grunnlovsdagen. I «det gamle samfunnet» hadde religiøse høytider eller rytmen i den førindustrielle økonomien hatt den samme funksjonen. Når folk kom sammen på denne måten, ga det anledning til konkurranser og spill. 17. maifeiringen introduserte en ny type festdag; «17. mai var en verdslig og ikke-religiøs begivenhet, den var politisk og ikke minst var den nasjonal og ikke lokal». ${ }^{69} \mathrm{I}$ de tidligste 17. maifeiringene var ikke selve idrettsutøvelsen nasjonal i seg selv, men idretten var «anvendelig fordi det ga et mer demokratisk og folkelig tilsnitt på markeringen av dagen», som i utgangspunktet var en mobilisering av den urbane middelklassen, «tilgjengelig fordi den baserte seg på eksisterende ferdigheter og kunnskaper». ${ }^{\circ 0}$ Det er som en fortsettelse av en slik kulturell kontekst Werenskiolds etsning kan fortolkes.

I 1880-årene begynte man å oppdage det norske som lå gjemt i idretten som fenomen. Den folkelige interessen vokste, og skiløpingen ble tolket som en spesielt velegnet aktivitet for nordmenn. Skienes rolle som nasjonale symboler ble understreket ved «at skiløping ikke lenger bare var en god nasjonal idé i enkelte intellektuelles hoder, men at det ble en nasjonal aktivitet praktisert i brede lag av folket. Dette ga skiene et avgjørende fortrinn på tidens kulturelle dagsorden, hvor det gjaldt, bevisst eller ubevisst, å bygge en nasjonal identitet gjennom å finne, oppfinne eller bygge egne norske institusjoner.» ${ }^{71}$

I det nye synet på idrett lå det et behov for å legitimere den «unyttige» fysiske aktiviteten som ikke var relatert til arbeid, ved å fokusere på ytre, edlere formål som sunnhet og helse. En årsak til at ski var blant de kultursymbolene som lot seg etablere, var at den entusiastiske, intellektuelle elitens idé ikke var uten fundament. Den ga gjenklang i en folkelig, klasseløs erfaring. Erik Werenskiold benyttet seg av den vinterlige aktiviteten som symbol, ikke bare i raderingene, men også i litografiene, og visualiserer dermed de demokratiske forestillingene om det sunne, aktive livet hvor naturen ble brukt som arena. Både fjellmotivene og motiver som gjengir unger på ski, bekrefter at Werenskiold fortsatt valgte å holde fast ved noen av de motivene som «folk flest» lett assosierte med det nasjonale.

Vekslingen mellom de mer nøkterne og nærmest ubetydelige utsnittene av naturen og natur som lett lar seg tolke inn en etablert nasjonal ramme, trer tydelig fram i Werenskiolds grafikkproduksjon. Dette går igjen i raderingene, men også i litografiene, som vi skal se. Det nye nøkterne er hovedsaken, men går innimellom hånd i hånd med «det gamle» som lett lar seg koble til 180o-tallets forestillinger, til tross for at ideen om det nasjonale i kunsten ikke lenger har den samme relevansen som tidligere.

68 Myhre, Asker og Barums historie: Barum 1840-1980, 243.

69 Goksøyr, «Idretten og det norske: aktivitet som identitet», 162.

70 Ibid., 163.

71 Ibid., 163. 


\section{KAPITTEL 2}

\section{Litografier}

\section{Perioden 1917-1938}

Erik Werenskiold laget sitt første litografi i 1917. Litografiene ble til i raskt tempo, og i 1918, hans mest produktive år når det gjelder denne teknikken, litograferte Werenskiold 34 motiver. I Werenskiolds håndskrevne grafikkoversikt er det notert 131 litografier med opus-nummer. Han opplyser, som riktig er, at oversikten mangler noen verk fordi deler av listen er skrevet mange år etter at litografiene ble laget. Og ikke uventet er dermed flere litografier funnet i løpet av arbeidet med katalogen som presenteres i denne boken. I perioden fra 1917 til 1938 laget han, ifølge registreringsarbeidet, 161 litografier. Katalogen til den store Minneutstillingen for Erik Werenskiold i Kunstnernes Hus, Oslo i januar 1940 bekrefter også et høyere antall enn det som kommer fram i Werenskiolds oversikt.

Litografiene, som i all hovedsak er tegnet med litografisk stift på papir, har i likhet med raderingene et variert formspråk. Men i flere av dem kan vi se igjen de stiliserte, noe stivere og flatepregede, mindre modellerte formene som også ble karakteristisk for naturgjengivelsen i Werenskiolds sene malerier. Dette er framtredende i litografiene Unghesten (1920) og Folungen II (1929) og i det aller siste litograferte motivet Lensekara I (1937) og II (1938). I litografiet fortsetter Werenskiold den samme organiseringen av bildeflaten som i raderingene; han reduserer de omkringliggende detaljene til et minimum og fokuserer på hovedmotivet i bildet, mens han opprettholder en stødig forbindelse til naturalismens bildespråk, og utnytter gråtoneskalaens maleriske og modellerende mulighet. Som en generell betraktning kan vi si at i arbeidet med grafikken, som hele tiden løp parallelt med utviklingen av maleriet, beholdt Werenskiold mer av plastisiteten i figurframstillinger og landskap enn det som er tilfellet i maleriet.

Mer enn for raderingenes del, oppfatter Werenskiold litografiet og tegningen som sidestilte. I brevene til Grønvold er dette en gjennomgående oppfatning. For Werenskiold handlet gode raderinger om å utvikle en teknikk. For å lage gode litografier gjaldt det å holde tegneferdigheten ved like. Han skriver til Grønvold: «Har laget mange store litografier. Men så kom denne armen i veien, men jeg var så godt «optegnet». Jeg tror disse litografiene når langt over mine tidligere.»

1 Brev fra EW til BG datert 20.10. 1920. NB. 


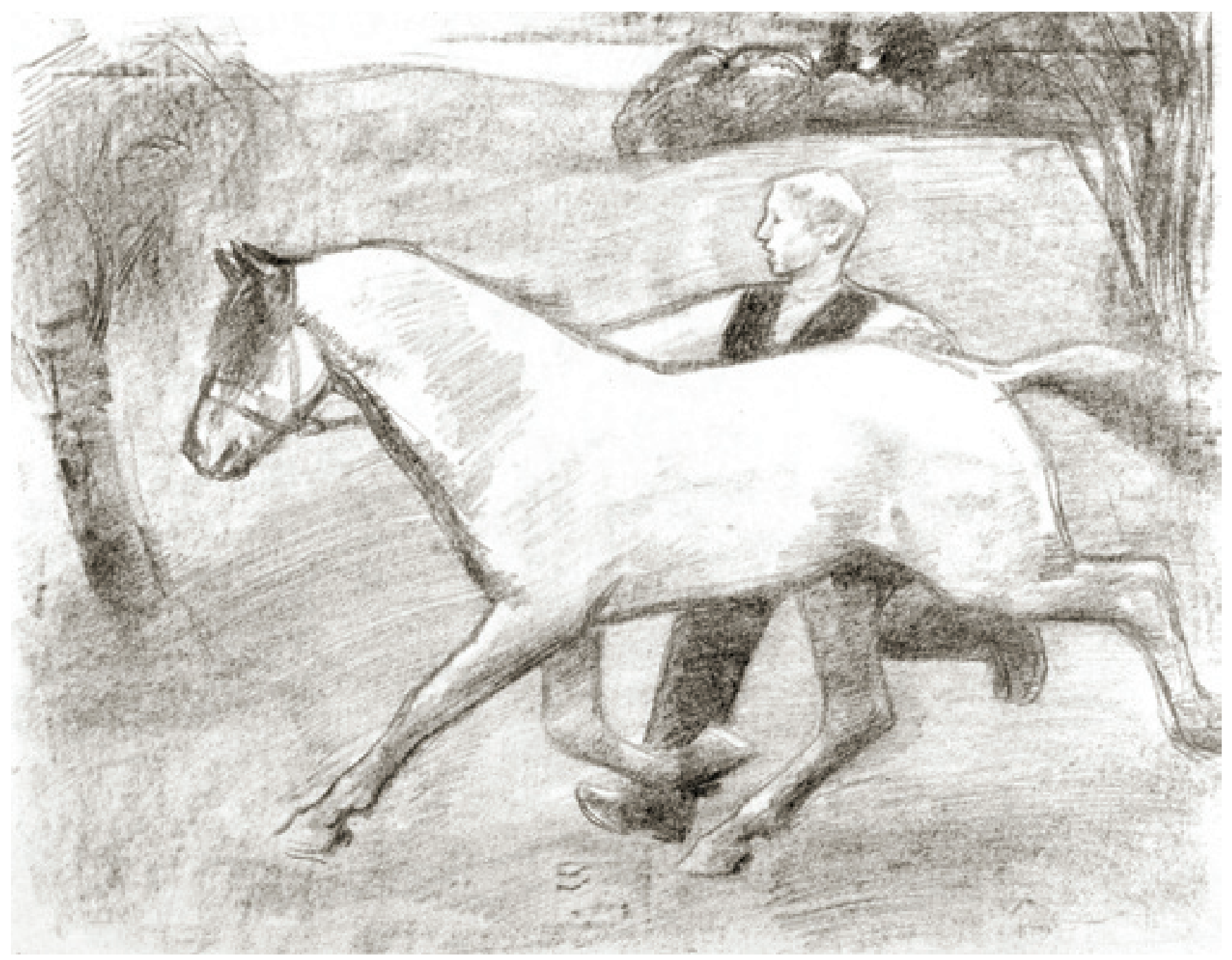

Unghesten, 1920. Litografi. (Kat.nr. 132)

Det var ikke bare Werenskiold selv som betraktet litografiet som en fortsettelse eller utvidelse av tegningens felt. Synspunktet gikk også igjen i avisomtalene. I 1918 skrev Kristian Haug i Aftenposten: «Den udstilling af lithografier han nu har i Kunstnerforbundet, har jo særlig interesse ved den for ham nye maade at lave kunst paa - eller rettere sagt det nye middel, den er lavet med - der som alt andet fordrer øvelse. Men andet end tegning med lithografkridt er det ikke. Det skal endog være behagelig at tegne med; blødere, mere nuancerigt end andet tegnemiddel. Og naar Werenskiold er vor bedste tegner, er det ligegyldig hvad han tegner med. Det bliver ialfald ikke daarligere ved at midlet er det bedste. Disse lithografier 


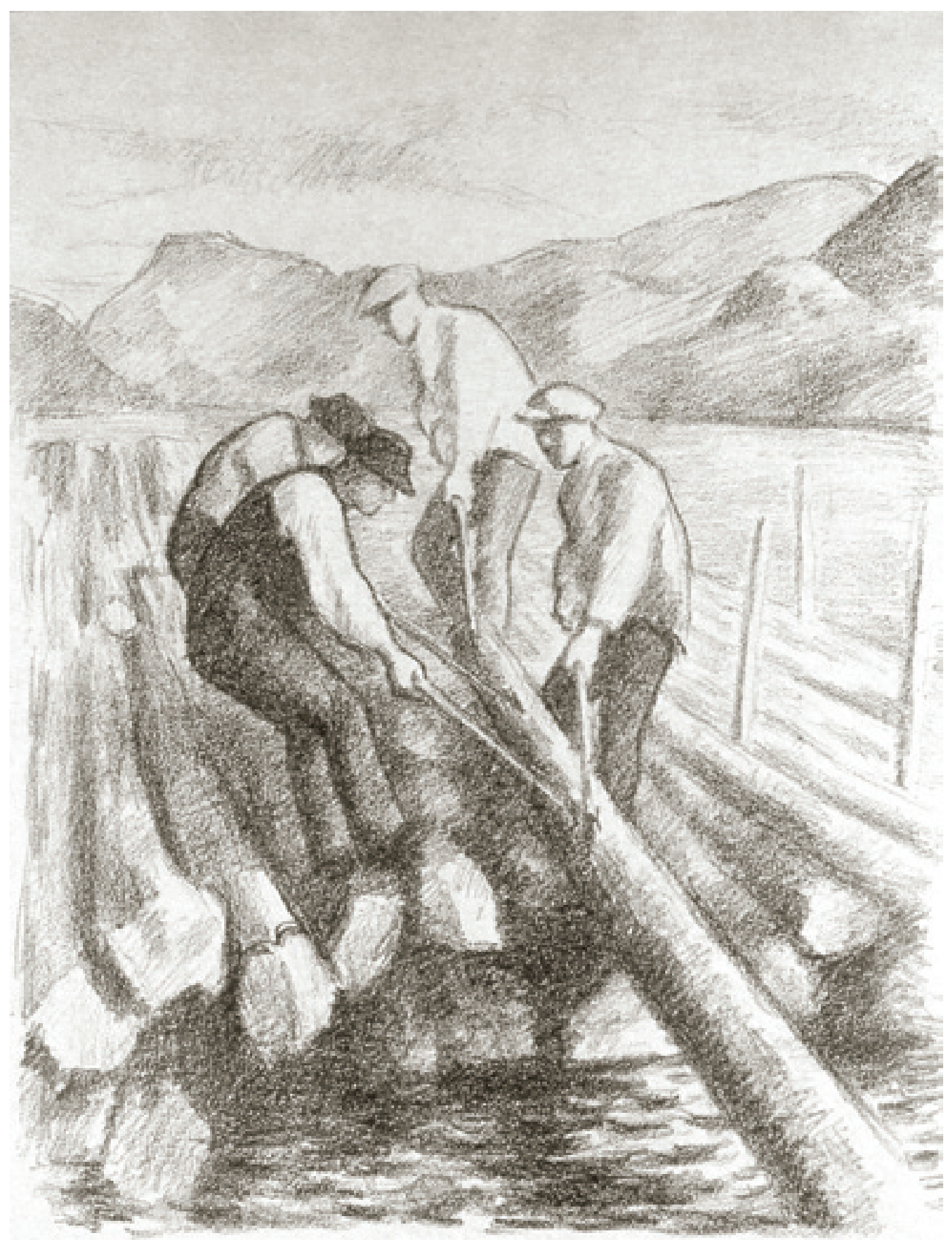

Lensekara II, 1938. Litografi. (Kat.nr. 247) 
er som sort og hvid kunst, eller som tegnekunst, kanske ikke bedre eller paa høide med det bedste Werenskiold har præsteret med andre tegnemidler, men de er særdeles vakre, og materialet synes at passe ham fortrinlig. Det giver malerisk virkning, fortones let og blødt fra dybt sort til det anende luftige, og har den fordel at kunde reproduceres.» ${ }^{2}$

Den rike bruken av gråtoneskalaen er karakteristisk for hele Werenskiolds litografiske produksjon. Nyansene spenner mellom følsomme, lyse grå til mer markante og mørke valører, og i all hovedsak med en transparent virkning. Werenskiold foretrakk litografisk stift som tegneredskap, og utnyttet i liten grad lito-teknikkens opake mulighet. Den transparente og lette effekten kommer fram enten ved hjelp av skrå- og kryss-skraveringer eller ved en utnyttelse av den frie, myke linjen i kombinasjon med det hvite i arket. Slik som i raderingene blir linjen uttrykksbærende også i litografiene. De to bildeuttrykkenes svært forskjellige karakter skyldes i størst grad det mediespesifikke.

Som eksempel på den varierte strekføringen kan vi trekke fram motivet Melkehesten (1918), hvor de nakne løvtrærne i forgrunnen formes ved hjelp av lette streker og en utnyttelse av det hvite i tegnearket, noe som på en følsom måte får fram det gjennomskinnelige i greinene. De tunge granene i mellomgrunnen blir stående som en virkningsfull kontrast til dette lette og lyse. Bartrærne er tegnet ved hjelp av tettere linjer som gir mørkere valører som får dem til å framstå med en fasthet i formen. Den samme bruken av valører kan vi se i de tre litografiene Fabrikkpipen (1917) og Lysakerfabrikken I og II (1918), hvor motivutsnittene er de samme, mens gråtonenes virkning og plassering varieres. Her fører det blant annet til at Lysakerfabrikken I med sine mørke trær i forgrunnen og den lyse åsen i bakgrunnen, får en større dybde enn de to andre arbeidene som mangler tilsvarende kontraster. Denne maleriske, følsomme måten å bruke gråtoneskalaen på ble kommentert av Finn Nielssen i Tidens Tegn da Werenskiold holdt sin siste utstilling i Kunstnerforbundet i 1938: «I kabinettet utstilles grafikk som for største delen er kjent fra før. Man konstaterer påny at Erik Werenskiold er den gudbenådede tegner, uten overmann, uten sidemann. Hans tegninger er i virkeligheten malerier hvor farven er forenklet til sort og hvitt. Jeg vet ikke om noen der med så sparsomme midler kan opnå en slik rikdom i tonen.» ${ }^{3}$

Werenskiolds grafikk viser en variert bruk av perspektiviske virkninger. Dette gjelder både for raderinger og litografier. De kompositoriske grepene veksler mellom tre ulike løsninger: for det første et grunt rom hvor romvirkningen er redusert til et minimum, og for det andre en mer tvetydig bruk av romdimensjonen, som fører til at vi ikke helt kan bestemme om rommet er uendelig eller uten betydning. For disse to karakteristikkene er det ofte slik at en eller flere figurer er plassert i forgrunnen og utgjør hovedmotivet, noe som gir nærhet til figurene. Denne komposisjonsformen er for eksempel brukt i flere portretter. Den tredje varianten har et definert og dypere perspektiv og kan først og fremst knyttes til landskapsmotivene.

I En alvorlig samtale (1922) finner vi det grunne bilderommet. Her er dybdevirkning redusert til et minimum slik at bildeplanet bare rommer de tre pikene og den benken de sitter på. Bak dem ser vi et uregelmessig bladverk som er plassert tett opp til hovedfigurene. Inntrykket blir urolig. Figurene forsvinner nærmest inn i mellomgrunnen. Kommunikasjonen med betrakteren uteblir, noe som også understrekes av blikket til hver av de tre, som ser ut til å stirre ut i ingenting. Motivet har visse likheter med litografiet Boken fra samme år og er sannsynligvis fra samme situasjon. Litografiet gjengir to av

2 Haug, «Erik Werenskiold», i Aftenposten 5.10. 1918 (Aftenutgaven).

3 Nielssen, «Erik Werenskiold i Kunstnerforbundet.», i Tidens Tegn 9.3. 1938. 


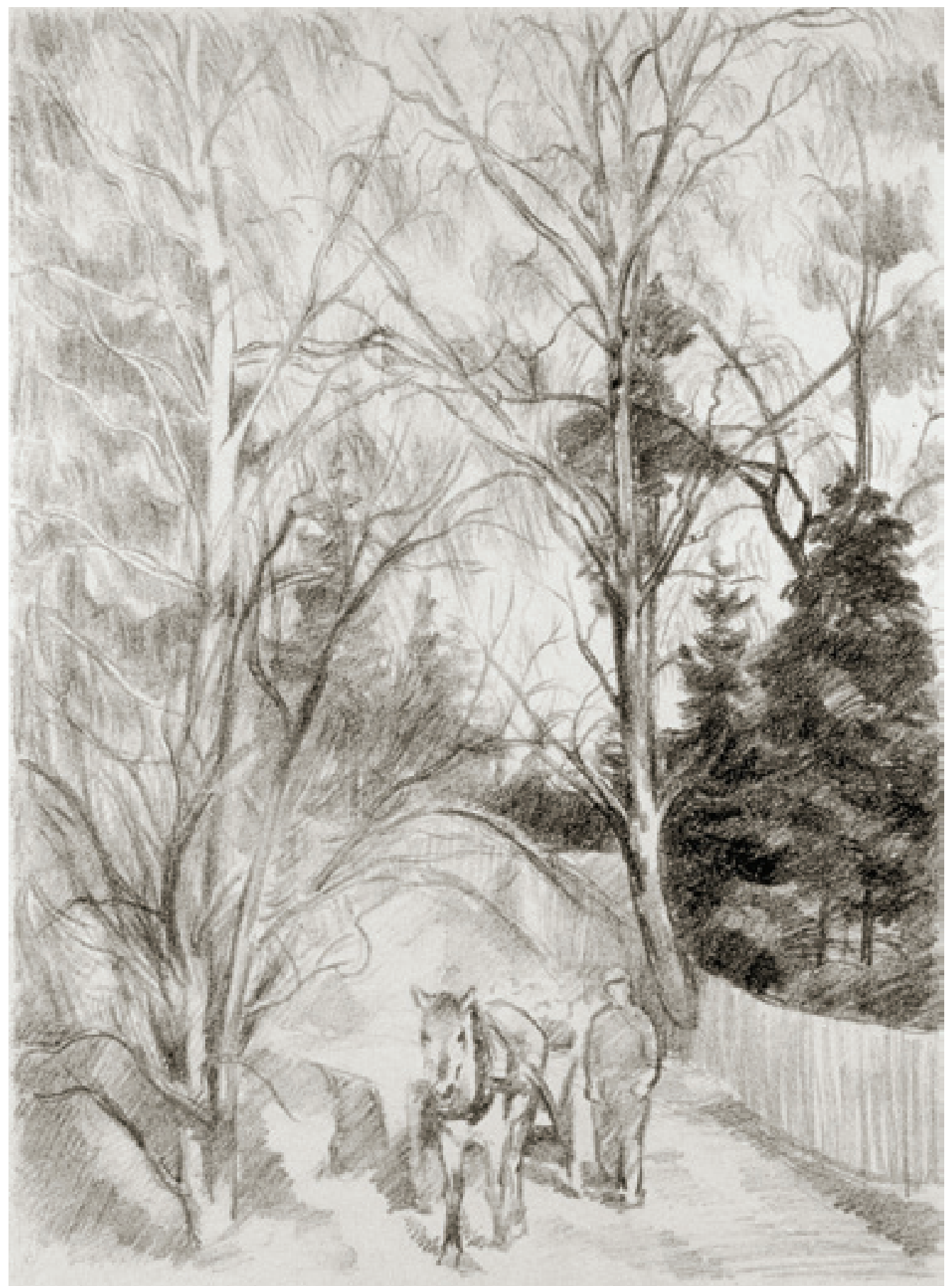

Melkehesten, 1918. Litografi. (Kat.nr. 80) 


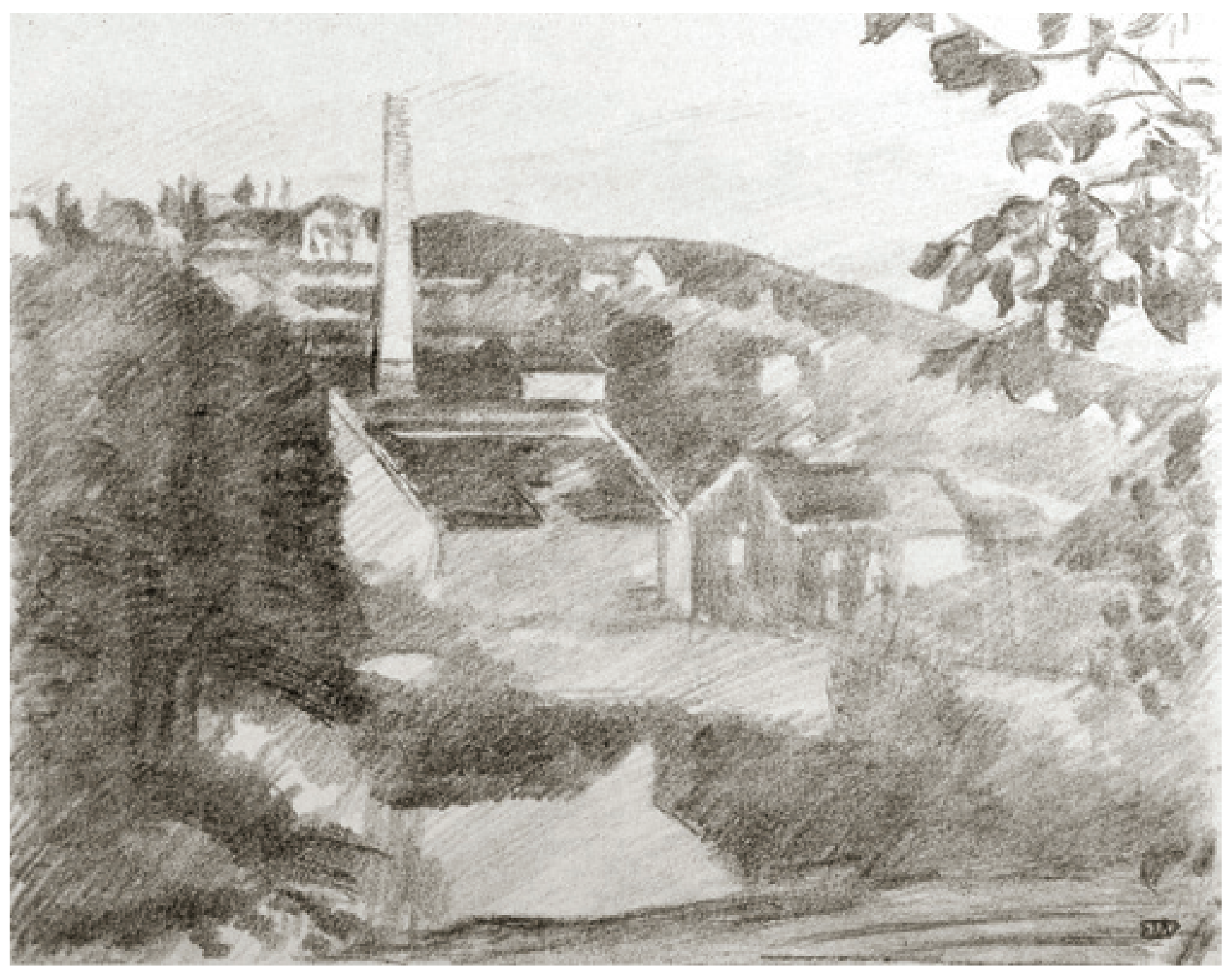

Fabrikkpipen, 1917. Litografi. (Kat.nr. 78)

pikene på den samme benken, her plassert i et udefinert rom. Slik motivet framstår, får det en nærmest svevende, lys og luftig karakter. Det Werenskiold framfor alt oppnår ved å plassere sine figurer mot en nøytral bakgrunn, er et fokus på figurene. De to sitter tett inntil hverandre. Den eldste og største av de to legger armen rundt den minste. Begge er oppslukt av det de leser i boken som ligger i den eldste pikens fang. Føttene, hendenes plassering og de bøyde hodene beskriver på en overbevisende måte pikenes konsentrasjon. Werenskiold som observatør og formidler viser seg her i hans evne til å fange og framstille kroppsspråk og ansiktsuttrykk, og den tomme bakgrunnen øker opplevelsen av det stille rommet rundt de to figurene, både i konkret og overført betydning. 


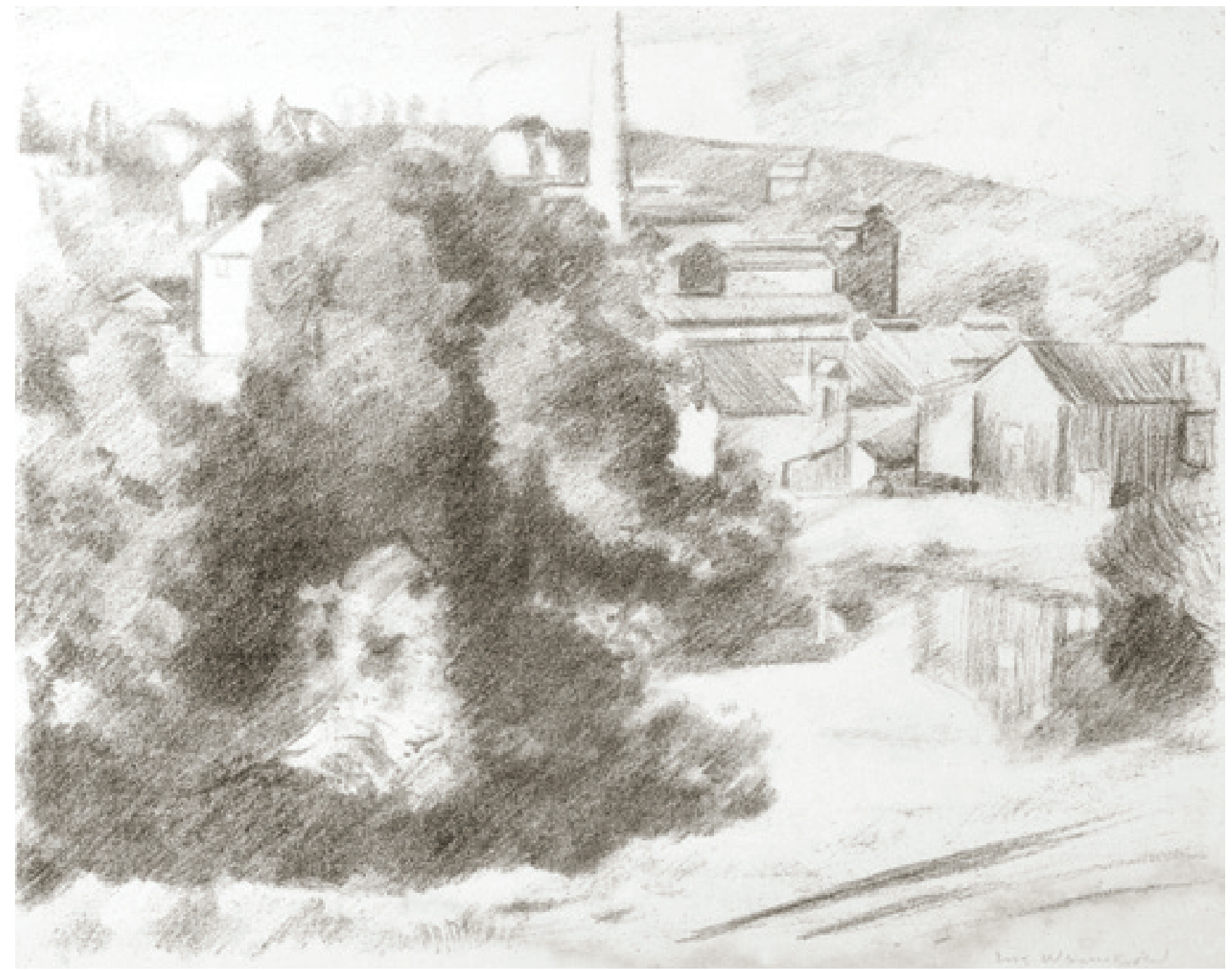

Lysakerfabrikken I, 1918. Litografi. (Kat.nr. 112)

I landskapsmotivet Glomma fra Kongsvinger festning (1929) presenteres betrakteren for utsikten fra høyden ved festningsverket. Betrakterens blikk føres innover i bildet ved hjelp av linjene som utgjør elvebredden til disse forsvinner under horisontlinjen. Det taktile i forgrunnens vegetasjon, formulert ved hjelp av mørke valører, står i kontrast til de mer summarisk oppfattede og vagt antydede åsene i bakgrunnen, noe som forsterker den perspektiviske virkningen. Variasjonen i perspektiviske virkninger og modellering av gråtoner viser Werenskiolds særdeles finstemte musikalitet i bruken av svart-hvitt-medier. 


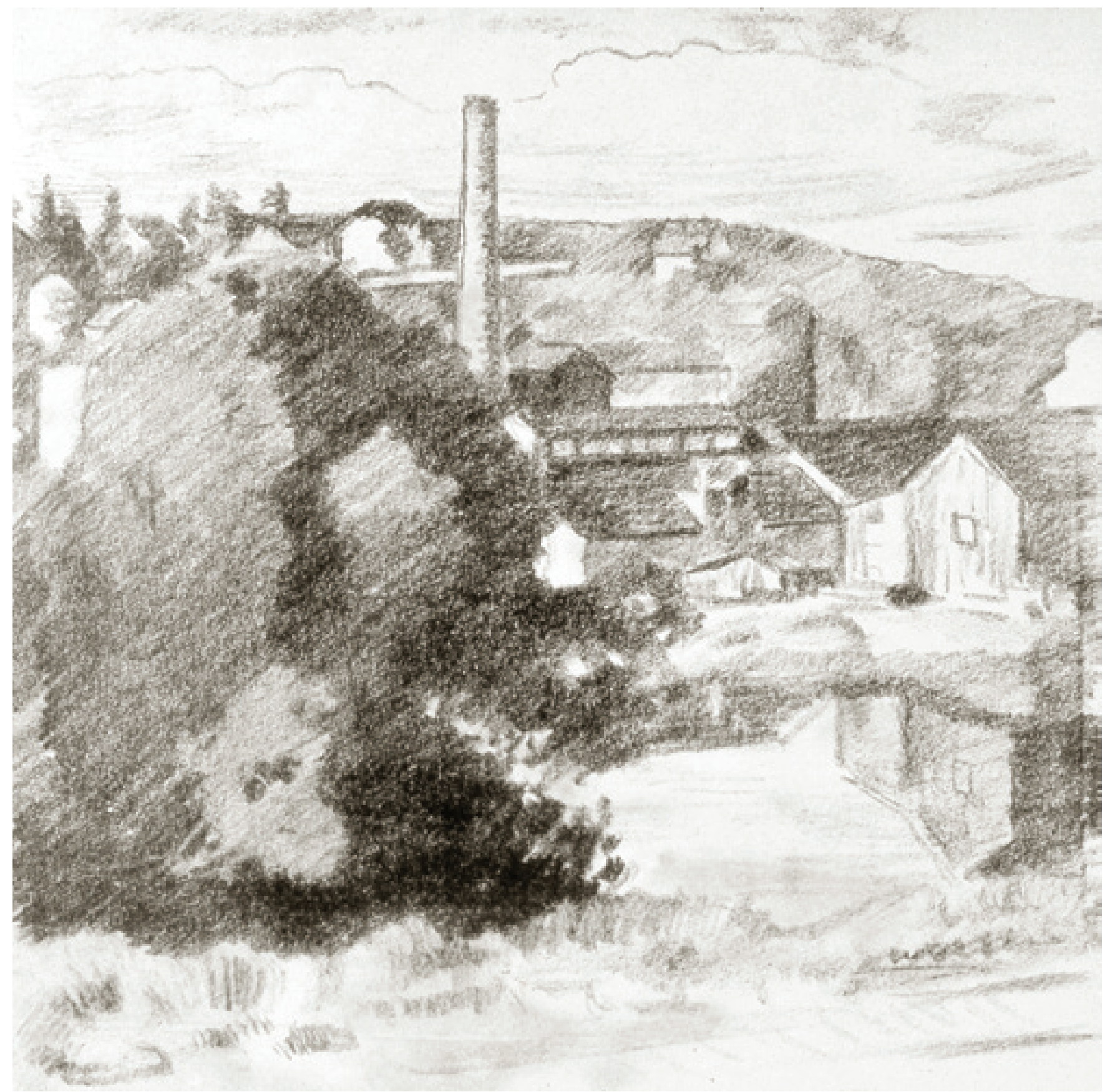

Lysakerfabrikken II, 1918. Litografi. (Kat.nr. 113) 


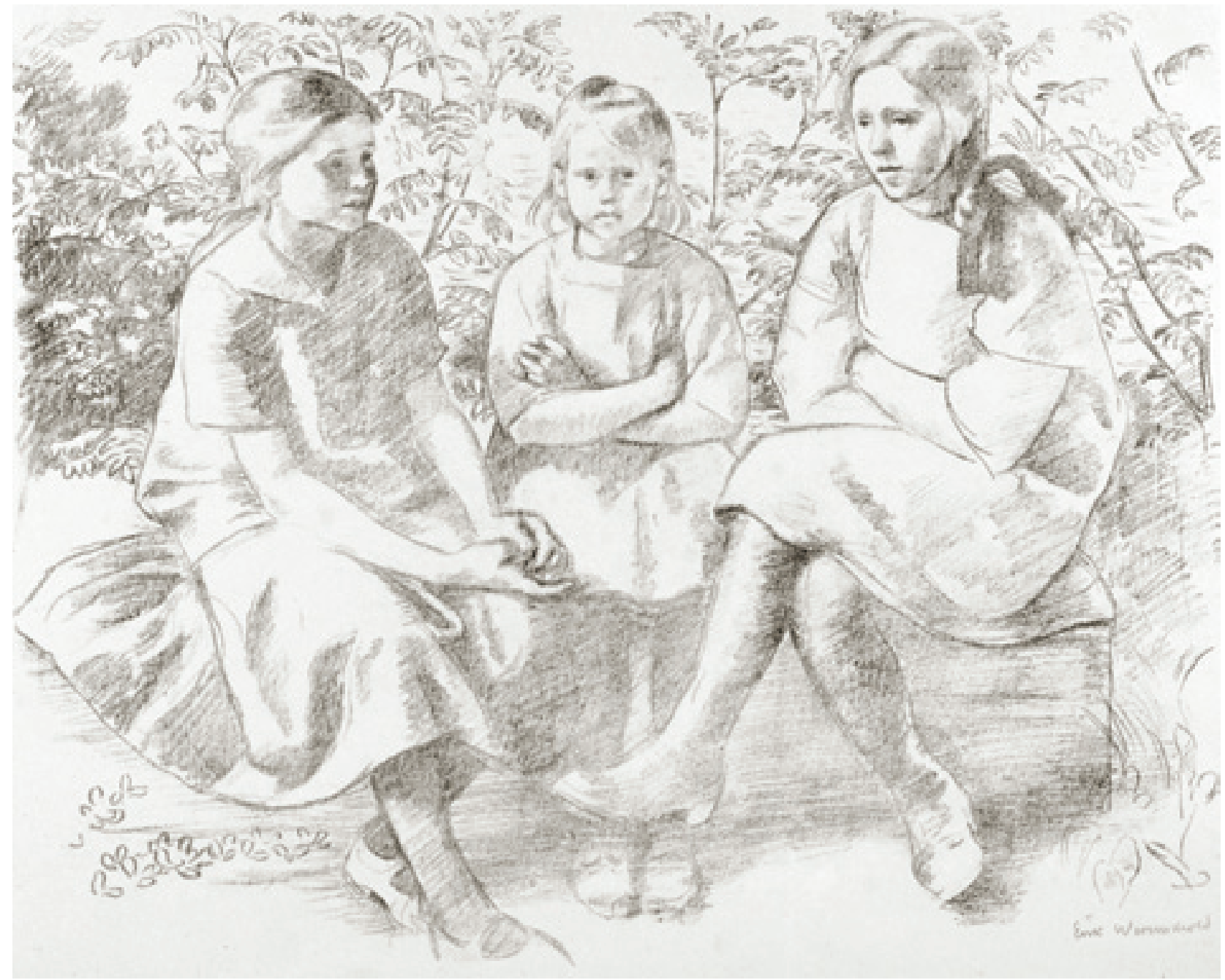

En alvorlig samtale, 1922. Sinkografi. (Kat.nr. 175)

Erik Werenskiold brukte tegningen, den litografiske inkludert, som en støtte for maleriet. Ved stadig å holde tegneferdigheten ved like fikk han selvfølgeligheten inn i utformingen av figurene. For Werenskiold kan det se ut til at tegningens nitide og modellerte form var en forutsetning for den stiliserte forenklingen han strevet etter i maleriet: «Jeg har litografert Nils Collett Vogt. Når Du ikke er så optat skal jeg sende Dig noen av mine senere lithografier. Jeg vil prøve at drive mig ordentlig op, jeg maler også meget bedre, når jeg er trenet i tegning.»${ }^{4}$

4 Brev fra EW til BG datert 3.3. 1920. 
LITOGRAFIER

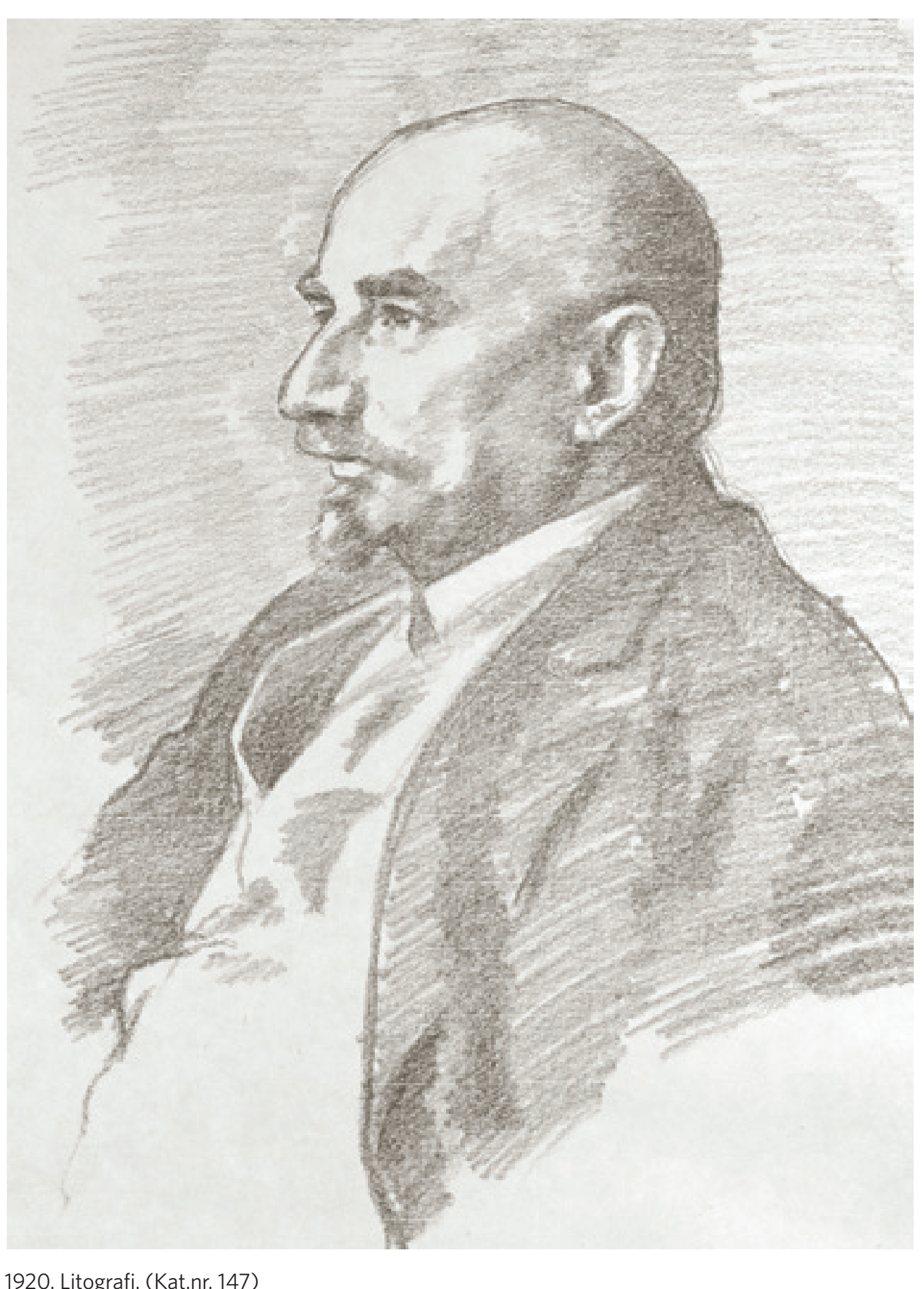

Nils Collett Vogt, 1920. Litografi (Kat nr. 147) 
Mange av Werenskiolds verk har blitt til gjennom en fruktbar veksling mellom uttrykksformer, og det finnes flere eksempler på at Werenskiold tok opp noen av de samme motivene både som raderinger, litografier, akvarell, tegning og maleri. Blant de motivene som gjengis i flere medier, finner vi raderingen Trollkjerringa og de tre prinsessene (1911) og en tidligere pennetegning til folkeeventyrene. ${ }^{5}$ Raderingen Lysakerbrua, vinter (1908) ble også malt med olje på lerret i verket Fra Lysaker (1909). ${ }^{6}$ Det finnes også flere eksempler på raderinger og malerier som gjengir nærmest identiske utsikter over Lysakerfjorden. Raderingen Underjordiske (1913) og maleriet Underjordiske (1926), raderingen Saga (1918?) og akvarellen med samme tittel fra 1918, de to litografiene Gutten som hugger hodene av trollet (1930) og en tidligere pennetegning til folkeeventyrene (1884) er andre eksempler. Videre kan litografiet Alle skogens dyr (1935) og nok en akvarell med samme motiv fra 1935 nevnes. Og sist, men ikke minst det kjente motivet i litografiene Lensekara I og II (1937/1938) som han også malte i 1938 .

Werenskiold lot seg ikke utfordre til å eksperimentere med litografiets virkemidler. Han fortsatte sin godt innarbeidede tegnemåte og sitt naturalistiske bildespråk. Gjennom et konsekvent formspråk gjør han kunsten lett tilgjengelig. Tegnemåten er autografisk og like karakterfast som hans signatur. Kristian Haug i Aftenposten, som er nevnt tidligere, skrev videre i forbindelse med utstillingen i Kunstnerforbundet 1918: «En sterkt personlig kunstner kan ikke helt følge tidens moder og svingninger, om han aldrig saa gjerne vil. Hvor meget han anstrenger sig, saa bliver der dog noget af personen igjen, noget af det, som er værdien i hans kunst. En kunstner er sig selv og ingen anden. Det stjæles, det anbefales endog, men det som er kjernen i al kunst, det kan ikke stjæles. Det kan kun blive et bedrag, som engang opdages. Man kan udvikles, man kan afklares, men bytte sjæl kan man ikke. [...] I dygtigheden og den personlige begavelse bliver han siddende enten han maler, tegner, raderer eller lithograferer. Det som vi helst beundrer som det værdifuldeste ved hans kunst, kommer altid frem.» ${ }^{7}$

\section{Portretter, landskap og hester}

I litografiene finner vi et bredt spekter av motiver. Portretter utgjør den største gruppen. Her finner vi motiver av venner og kolleger, barn og voksne og av egen familie. Omkring 70 av de totalt 161 litografiske verkene kan plasseres innenfor denne kategorien. Også landskapet i all sin variasjon har sin selvfølgelige plass i rekken av litografier. I litografiene flytter Werenskiolds geografiske plassering seg fra Jotunheimen, som er et mye brukt område i raderingene, til Valdres og Telemark. Mens områdene på Lysaker, hvor han bodde, fortsatte å være en inspirasjon. Et flittig brukt motiv, som ofte forbindes med Erik Werenskiold, er skildringer av hester, enten som en stabil og trofast deltaker i bondens arbeidsdag eller fredelig på beite. Hesten gjengis bare i én radering, men i rekken av litografier finner vi flere.

Alle skogens dyr (1935) inngår som den eneste rent dekorative komposisjonen. Werenskiold har litografert bare to eventyrillustrasjoner: Huldra (1924 og 1933) og det populære motivet Gutten som hugger hodene av trollet (1929 og 1930), gjengitt i henholdsvis tre og to varianter.

\footnotetext{
Asbjørnsen, Norske Folke- og Huldreeventyr i Udvalg. Asbjørnsen, Eventyrbog for Børn, 1-3.

Samme motiv utført som maleri og radering knytter Werenskiold til begrepet malergravør brukt i kapittel 1.

Haug, «Erik Werenskiold», i Aftenposten 5.10. 1918 (Aftenutgaven).
} 


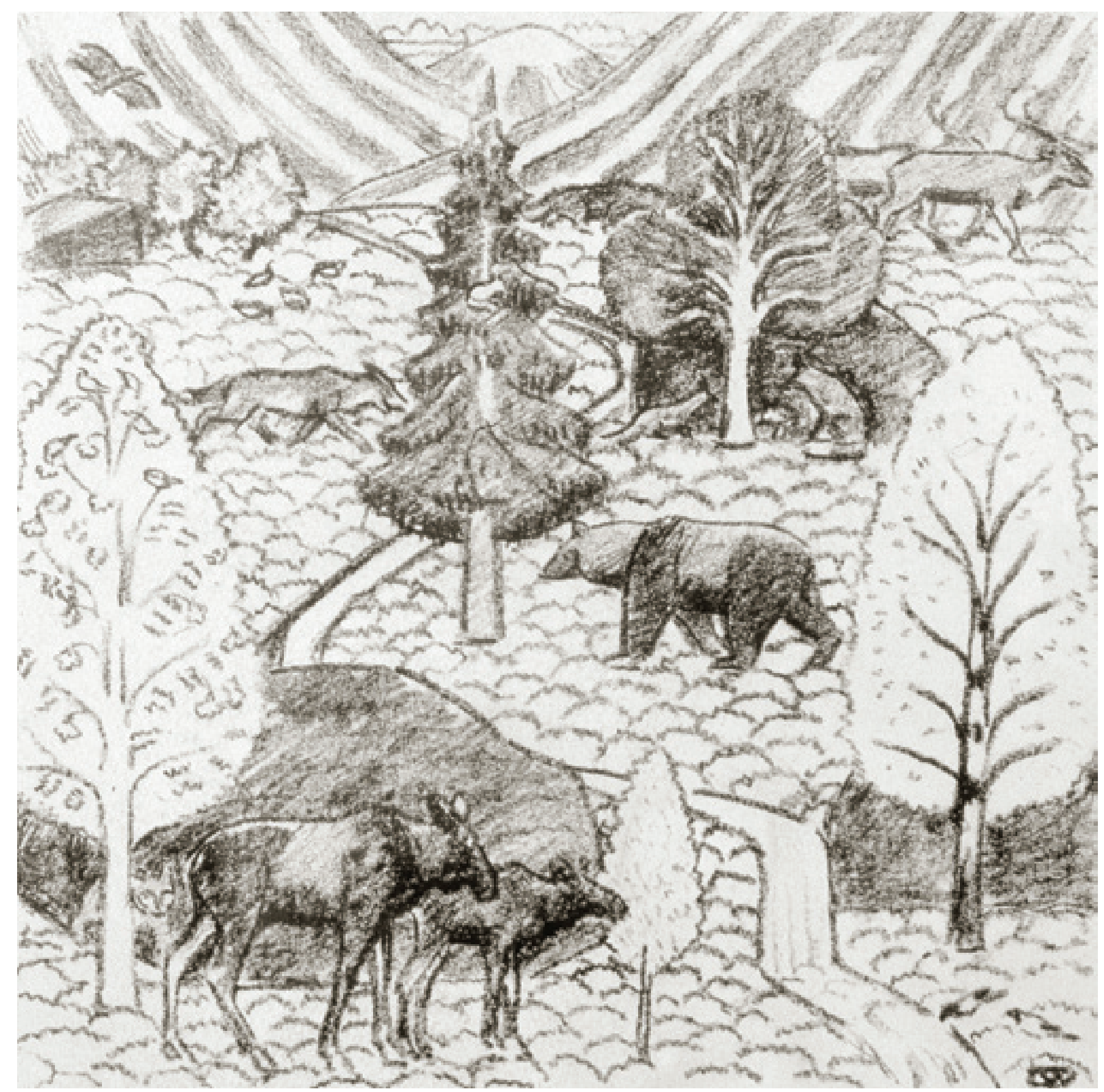

Alle skogens dyr, 1935. Litografi. (Kat.nr. 229) 
Flere av Werenskiolds litografier gjengir hverdagslige hendelser og uanselige og anonyme steder. Vi finner flere av disse nærmest «uinteressante» motivene i Werenskiolds grafikk. Det er til å undres over at han velger å tegne Dagfin som leser avisen og mor som har kledd på seg yttertøyet for å gå ut, eller bjørker på en haug og en like anonym og lite spektakulær snødekt helling med kratt og trær. Når det gjelder disse landskapene, er de fratatt enhver referanse til det lett romantiserende i malerier og tegninger fra 1800-tallet, og det totalt antiheroiske kommer til uttrykk i avbildningen av hverdagshendelser. På den måten skapes det en avstand til 1800-tallsnaturalismen og en forbindelse til en ny form for saklighet. Men med Werenskiold avbildning får disse motivene allikevel en verdi og betydning.

Kunst som visualiserer hverdagslivets hendelser, krever ingen bestemt kunnskap for å bli forstått. Motivene har en umiddelbar appell til mennesker med kompetanse på sin egen hverdag. Når man ser nærmere på Werenskiolds raderinger og litografier, vokser fascinasjonen over hvordan han hele tiden var i stand til å holde fast ved disse «små», «uviktige» motivene som gjennom hans distanserte blikk og formale løsninger framkaller en intim atmosfære: «Certain Norwegian painters $[\ldots]$ turned inward for their themes, becoming intimists, who painstakingly recorded episodes from daily existence. ${ }^{8}$ Det hverdagslige, alminnelige finner vi i de nettopp nevnte motivene Dagfin leser avisen (1919) og Mor leker fremmed dame (1920), og også i verk som Tømmerlasset (1928), Høykjøring i fjellbygda (1931) og Høylasset oppover låvebrua (1933). De tre sistnevnte som er beslektede motiver fra bondens hverdag, visualiserer noen av gjøremålene som inngår i gårdsdriftens årssyklus: skogsdrift om vinteren og innkjøring av tørt høy en sommerdag slik at forsyningen av fôr til kyr og hester kan lagres for vinteren. Motiver som er relatert til gården og gårdsdriften, «avspeiler en syklisk livsform som kretser om gjentagelsen av de samme arbeidsprosedyrer og de samme eksistensspørsmål». ${ }^{9}$ Gården blir det faste punktet i tilværelsen. Flyttet man fra gården, flyttet man ikke bare fra et sted, man flyttet også fra en tid. Disse motivene inntar en slags mellomstilling. Her balanserer Werenskiold fint mellom den nøkterne, nærmest etnografiske registreringen av en hendelse og den romantiserte versjonen av landlig idyll.

Det velkomponerte og vellykkede vintermotivet Tømmerlasset er tegnet med uttalt frihet i linjeføringen. Den mørke hesten ses bakfra, og er plassert i bildets mellomgrunn med et tømmerlass etter seg. Hest og tømmer lager en virkningsfull diagonal i bildeflaten. De nyfelte stokkene som ligger på sleden, kommer nærmest ut av bildets forgrunn. Hesten er plassert på en lysning i skogen omkranset av varsomt antydet granskog med snø på. Med sparsomme midler har Werenskiold fått fram en fortettet stemning: stille snø, skogens ro, tungt tømmerlass, varm hest som venter tålmodig. Litografiet er et av de få hvor kontrasten går fra det helt hvite til det ugjennomtrengelig svarte.

I de noe senere motivene med høylass fortsetter Werenskiold å kommentere livet på landet knyttet til bondens hverdag. I alle de tre litografiene blir betrakteren plassert på et fordelaktig sted i forhold til motivet. Nært på, men langt nok fra til å kunne danne seg et helhetlig inntrykk av folk, dyr og omgivelser. Både i Høykjøring i fjellbygda og i Høylasset oppover låvebrua framstår alle figurene i bildet som like viktige. Hest, bonde, barn og kone er plassert ved siden av hverandre og utgjør et helhetlig arbeidsfellesskap. Figurene føyer seg sammen som ordene i en setning, og gir mening både individuelt

8 Weisberg, Beyond Impressionism: The Naturalist Impulse, 257.

9 Bjerke, Tun og vassdrag. Telemarks typologier, 5 . 


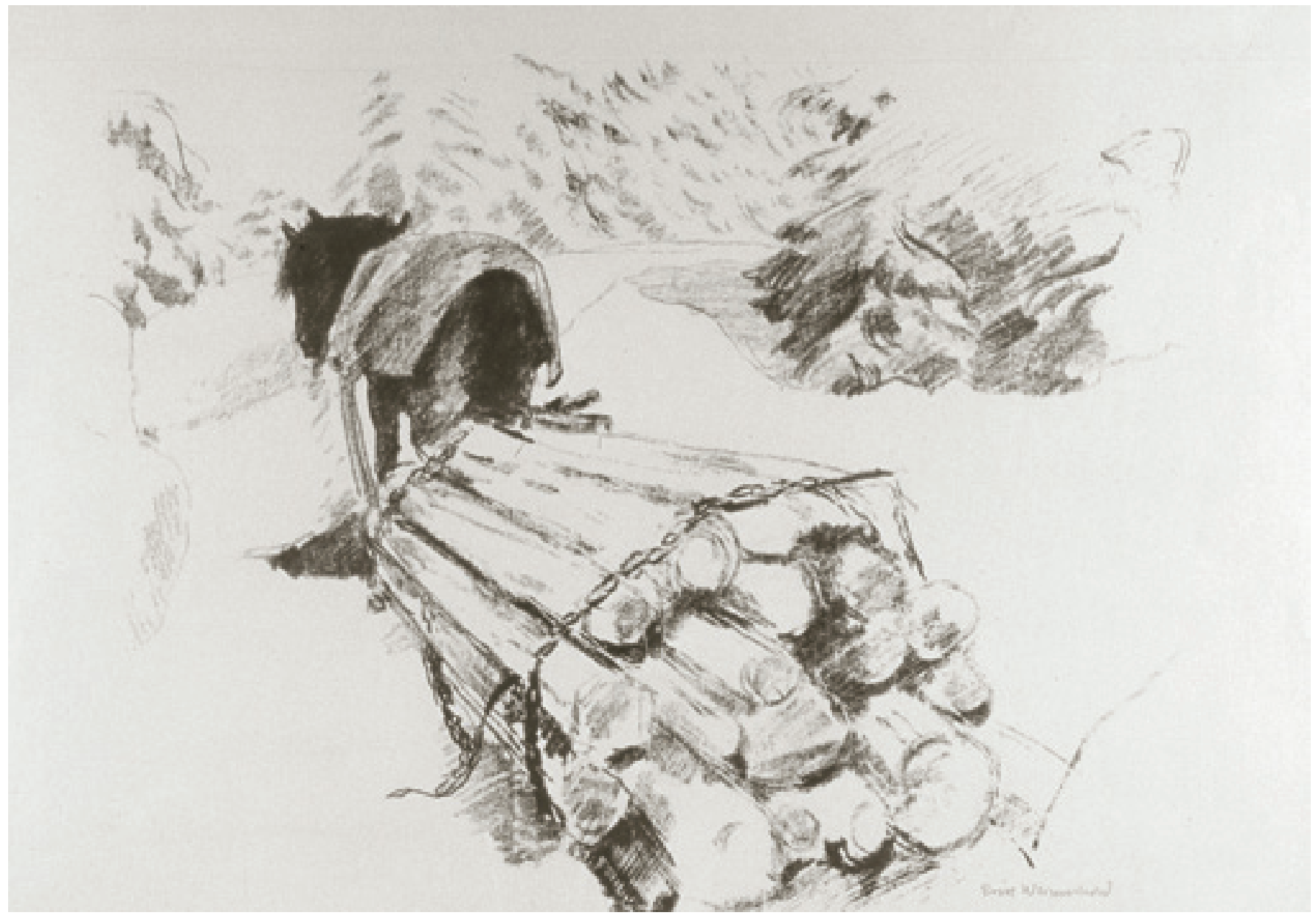

Tømmerlasset, 1928. Litografi. (Kat.nr. 189)

og samlet. Mennesker, dyr og omgivelser er gjensidig avhengig av hverandre. Balansen i de tre komposisjonene fører tanken over på stabiliteten i den tradisjonsrike produksjonsenheten.

\section{Revolusjon}

De motivene som hittil er nevnt, er typiske for Werenskiolds grafikk. Motiver som klart skiller seg ut fra de mer kjente motivkretsene, er to symbolsk ladede litografier: Planting (1918) og Revolusjonen (1921?). I Revolusjonen ser vi blodtørstige rotter like store som mennesker gå løs på nakne menneskekropper. Kroppene ligger i en kaotisk uorden, drept av rottenes målrettede bitt. Til venstre i bildet står en skrekkslagen menneskeskikkelse med ryggen til betrakteren og ser med fortvilelse og maktesløshet på det som skjer. 


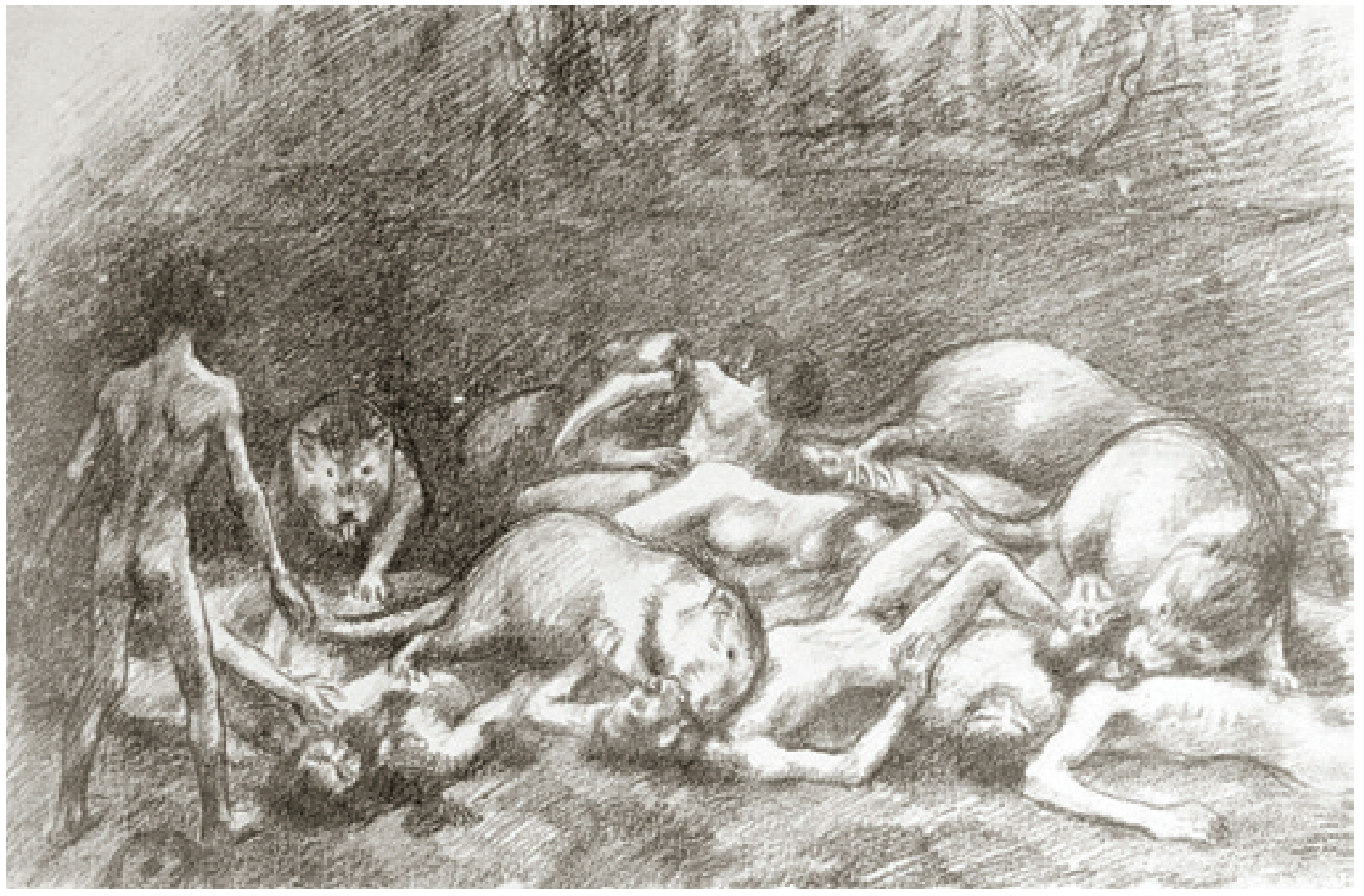

Revolusjonen, 1921?. Litografi. (Kat.nr. 169)

I brevvekslingen med Grønvold utover på 1900-tallet kommer Werenskiold stadig med sine bekymringer for verdens politiske helse, noe som forsterkes etter inntrykkene fra 1. verdenskrig. Han så med forferdelse på politiske og religiøse systemers maktutøvelse og skrev om den fortvilede situasjonen for det russiske folket etter 1917-revolusjonen med hungersnød og resignasjon. I litografiet Revolusjonen har rottenes blodtørstige hunger ført til (makt-)overgrep på uskyldige offer. Gigantiske, hensynsløse vesener tilfredsstiller sin sult ved å frata andre eksistensmuligheten. Werenskiolds rotter blir stående som representanter for maktens natur. «Der må en moralsk gjenfødelse til. Kanske en vældig sammenslutning av alt som heter kunst og litteratur kunde avføde en forandring! Jeg nevner ikke religionen fordi statskirken altid går ut fra at Vorherre er partimand, han skal hjelpe dem å knuse fienden! Først måtte religionen også gjenfødes, den måtte frigjøre sig fra statssamfundene. Men så har vi bolchewismen, som jo osså holder på de 
blodige midler, umenneskeligere end alt! Ingen utreder kjernespørsmålet: får individet utvikle sig frit, eller relativt frit, unner denne statsform? $»^{10}$

Ut fra denne tolkningen kan Revolusjonen ses som Werenskiolds samfunnsmanifest. Så grusom er makten i alle dens avskygninger! Så viktig er individets frihet! «Der må en moralsk gjenfødelse til.» Litografiet står som et imperativ i Werenskiolds grafiske produksjon.

10 Brev fra EW til BG datert 25.8. 1922. 


\section{Erik Werenskiolds grafikk og Paul Cézanne}

Da Erik Werenskiold for alvor begynte å radere i 1908, hadde han samtidig blitt oppmerksom på Cézannes kunst. Cézanne-inspirerte trekk hos Werenskiold har først og fremst blitt forbundet med likheter i det formale i maleriet. Men også i Werenskiolds grafikk finnes det grunnlag for sammenligninger som kan skape flere forbindelser mellom Werenskiolds og Cézannes kunst. Mer konkret handler dette om påfallende likheter i valg av motiver. Til tross for at de hentet motiver fra vidt forskjellige områder, den ene i Frankrike, den andre i Norge, har naturutsnittene de festet seg ved en påfallende felles estetisk modalitet. Ser vi igjennom de to kunstnernes produksjon, kan vi med letthet finne et større antall eksempler på denne typen fellestrekk. Også i enkelte portretter forekommer det en slående likhet, først og fremst i ansiktsuttrykk og positurer. Gode eksempler er Cézannes portretter av madame Cézanne og Werenskiolds raderte portretter av søstrene Heiberg og litografiet av fru Poulsson på verandaen mens hun holder på med et håndarbeid. ${ }^{2}$ Men gjennom den kunstneriske bearbeidelsen av det sette har uttrykkene, naturlig nok, forskjellig formspråk. Vi skal se noen eksempler på naturalistiske oversettelser av Cézanne-lignende motiver ved å sammenstille en radering og to litografier av Werenskiold med tre av Cézannes malerier.

På Berliner Secessionen i 1908 møtte Erik Werenskiold Cézannes bestemte blikk i Selvportrett med hvit lue (1881-1882). ${ }^{3}$ Det sterke inntrykket som dette maleriet ga, støttet opp under Werenskiolds idé om en ny blomstring i kunsten basert på «den sterke personlige utfoldelsen» $\mathrm{i}$ et direkte møte med den sette naturen. ${ }^{4}$ Bekreftet av Cézanne kunne Werenskiold «styre rolig videre» mot det han betegnet som «en renaissance på det 19de århundredes grundlag". ${ }^{5}$ Formuleringen uttrykker hvordan Werenskiold fortsatte inn i et nytt århundre uten det store opprøret, men veloverveid bygde videre på den naturalistiske formen fra 1800-tallet. På dette grunnlaget skulle hans formale og innholdsmessige løsninger føres i en retning hvor motivene ofte er uten figurer. Dermed tones det fortellende aspektet ned, og framstillingene kan ikke i samme grad som tidligere knyttes til 1800-tallets opptatthet av nasjonal identitet. Hos Cézanne fant han støtte for ideen om den

Fremmerlid, «Erik Werenskiolds grafikk og Paul Cézanne», kapittelet er en bearbeidelse av en artikkel i Kunst og Kultur, nr.3, 2012.

Fru Emma Stang (I-IV), 1915 (kat.nr.??), Fru Ingeborg Fearnley, 1915 (kat.nr.??) og På verandaen, 1918 (kat.nr.??).

Katalog der Fünfzehnten Austellung der Berliner Secession, Berlin 1908, 3. opplag. De franske kunstnerne i tillegg til Paul Cézanne var i all hovedsak nyere og eldre symbolister: Pierre Bonnard, Honoré Daumier, Maurice Denis, Georges Dufrenoy, Albert Marquet, George Mosson, J. Roussel og Edouard Vuillard. Ifølge katalogen stilte disse ni kunstnerne ut 19 verk til sammen. Tyngden i utstillingen var lagt på en større presentasjon av tysk kunst med Wilhelm Leibl som hovedfigur, representert med hele 57 verk. I denne settingen trer Paul Cézanne tydelig fram med et nytt og radikalt formspråk.

4 Erik Werenskiold, sitert i Andreas Aubert, Norsk kultur og norsk kunst, 192.

5 Ibid., 192. 
marginaliserte fortellingen og en større konsentrasjon om det rent formale. I artikkelen «Rembrandt og Cézanne» skriver Werenskiold at «fortellingen i et billede oftest [for ham er] temmelig likegyldig; den har jo ingen virkelig kunstnerisk betydning uten i det tilfælde at situationen er absolut malerisk tænkt: er bare billedet riktig godt som maleri, saa er det i sig selv fortælling nok. Cézanne er et godt eksempel paa dette». ${ }^{6}$ Denne oppfatningen av forholdet mellom fortelling og formale kvaliteter har også en gyldighet når det gjelder hans grafikkproduksjon.

\section{Det kjente landskapet}

Den personlige tilknytningen til landskapet som skulle gjengis, var vesentlig for de to kunstnerne. I likhet med Cézanne baserte også Werenskiold sin kunstneriske prosess på gjentatte møter med den samme naturen. Marit Werenskiold skriver i sin artikkel at for Werenskiold var «hagen på Gilje og utsikten over fjorden mot Bygdøy [et] uuttømmelig motiv, som det hellige fjellet Mont Saint-Victoire i Provence var det for Cézanne».7 I tillegg til motivtilfanget fra området rundt Aix-en Provence er landskapet nær L'Estaque et tilbakevendende tema hos Cézanne. Også området rundt Paris med Fontainebleauskogen og Auvers er gjenstand for hans analytiske blikk. I tillegg til områdene på Lysaker oppsøkte Werenskiold, som tidligere nevnt, områder i Telemark og fjelltraktene i Jotunheimen ved flere anledninger. I Werenskiolds fortolkninger framstår formspråket gjennomgående som mer statisk og rasjonelt enn hos Cézanne. Werenskiolds motiver uttrykker en slags følelsesmessig passivitet og kontemplasjon, snarere enn en rastløs søken som kan knyttes til Cézannes kreative prosess.

Et Werenskiold-motiv som gir assosiasjoner til Cézanne, er litografiet Svartdal. Dateringen er usikker, men sannsynligvis er det laget en gang mellom 1935 og 1937. Fjellet Knutshø i Telemark sett fra Svartdal viser formasjonen av fjelltoppen sentrert i bakgrunnen fra en vinkel som minner sterkt om fjellets formasjon i Cézannes framstillinger av Mont SaintVictoire. Cézannes Mont Sainte-Victoire fra 1900 domineres av den kjente fjellformasjonen sentrert i bildeflatens bakgrunn, og lave, bevokste koller konsentrert i forgrunnen. Cézannes behandling av motivet gir et grunt bilderom med redusert avstand mellom trærne, huset og fjellet. Resultatet er at mellomgrunnen nærmest forsvinner, og at forgrunn og bakgrunn smelter sammen til en flate av fargetoner med samme intensitet. Det er for eksempel de samme grønn- og blåtoner i bildets nedre og midtre del som det er i den øvre delen med himmel og skrånede fjellsider. Og den gylne fargeskalaen i skråningen til venstre er identisk med bebyggelsens. Den omtalte diffuse, urolige virkningen ses også her særlig i vegetasjonen. I Werenskiolds litografi finner vi en større vekt på illusjon av dybde. Dette oppnår han gjennom en tradisjonell gradering av gråtoner, fra de mørke grantrærne i forgrunnen til den lyse fjellformasjonen i bakgrunnen. Sammenlignet med Cézanne er Werenskiolds litografi preget av et naturalistisk formspråk, hvor han på karakteristisk vis beskriver de forskjellige kvalitetene i vegetasjonen.

Andre stedsspesifikke motiver med forbindelser til Cézanne finner vii Werenskiolds litografier som viser Lysakerfabrikken og bebyggelsen omkring. Disse minner om Cézannes åssider med spredt bebyggelse i form av kubiske og flatepregede, kantete elementer. Werenskiolds litografier fra landskapet i Rauland, med sjøen Totak, minner om Cézannes motiver fra

6 Werenskiold, «Rembrandt og Cézanne», 98.

7 Marit Werenskiold, «Erik Werenskiold og Paul Cézanne», 27. 


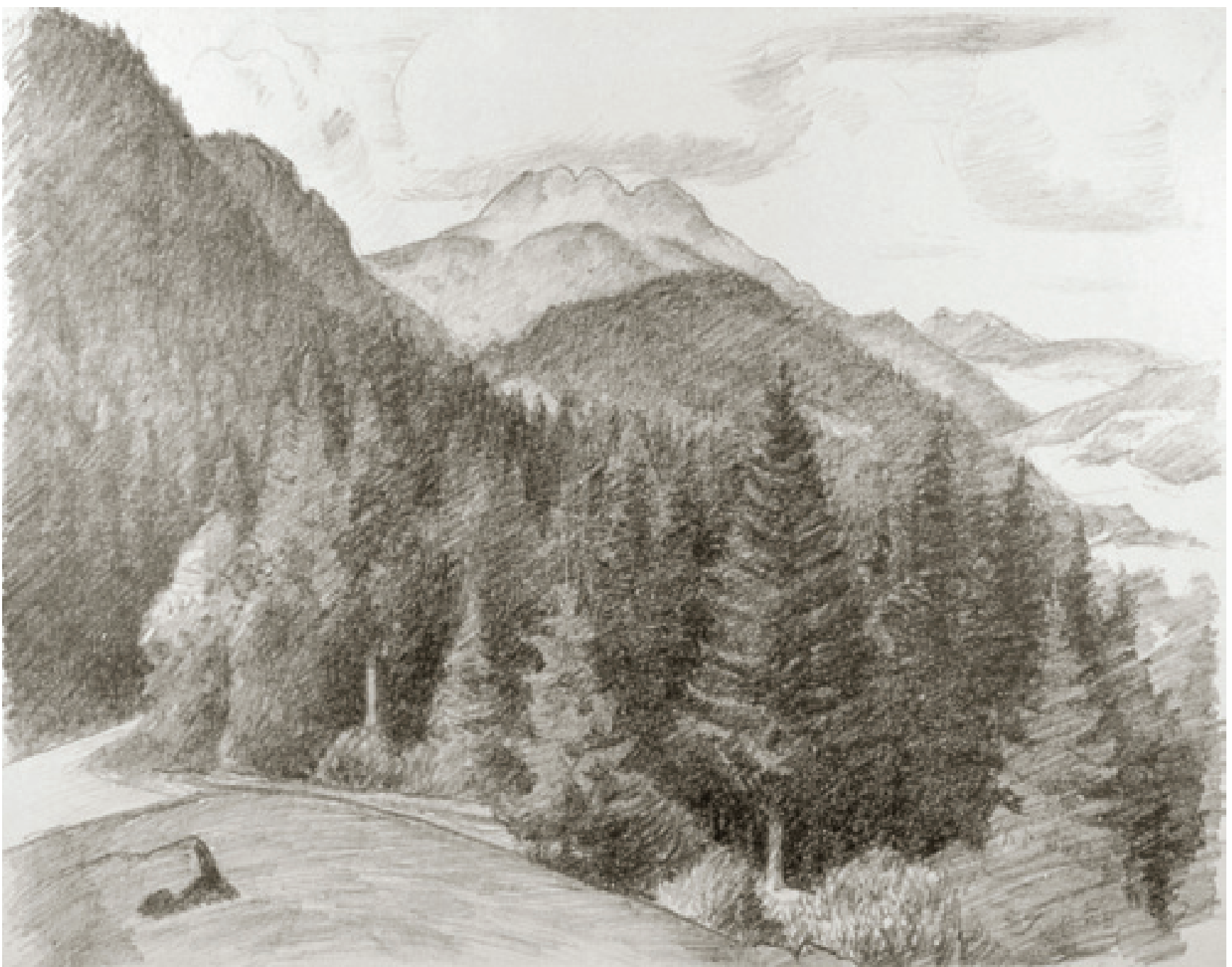

Svartdal, 1935-1937. Litografi. (Kat.nr. 236)

bukten ved L'Estaque. Felles for disse motivene, i likhet med de andre som er beskrevet, er det rene landskapet uten figurer. Dette gir den påpekte reduksjonen av fortelling i bildet og en større vekt på det formale.

Konsentrasjonen om det rene landskapet uten figurer kommer også til uttrykk i motiver som ikke kan stedfestes med sikkerhet. Både Werenskiold og Cézanne har produsert flere motiver med trær og steiner, som i og for seg kunne vært hentet fra et hvilket som helst område. Dette tydeliggjør konsentrasjonen om formasjoner og elementer i naturen og underbygger det formale fokuset hos dem begge. Eksempler på denne typen motiver finner vi i Werenskiolds litografi 


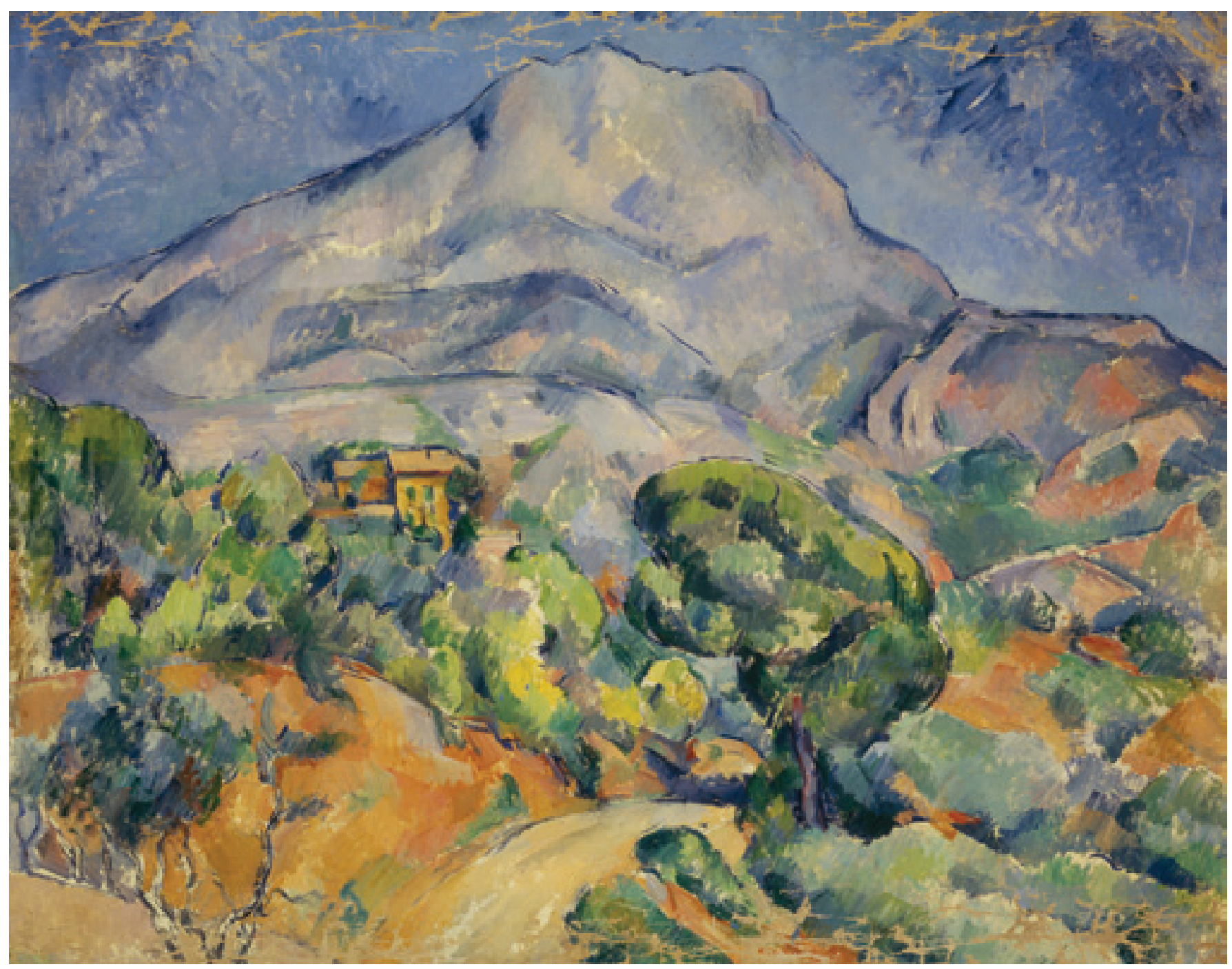

Mont Sainte-Victoire, 1900. Olje på lerret, 78 x 99 cm. (c) The State Hermitage Museum, St. Petersburg.

Gamle bjørketræer på en haug fra 1922 og Cézannes maleri Furuer og steiner (Fontainebleau?) fra ca. 1897. De to motivenes kompositoriske likhet er åpenbar, med trær som hovedelementer. Trærnes vertikale linjer avskjæres i begge tilfeller av bildekanten, samtidig som de skjuler himmelen i bakgrunnen. Cézannes bergknaus er hos Werenskiold erstattet med en haug, som gir en sammenfallende fornemmelse av vegetasjonens plassering i terrenget. Bildeflaten hos Cézanne rammes inn av trestammene som holder komposisjonen sammen i en logisk organisering, basert på et følelsesmessig inntrykk 


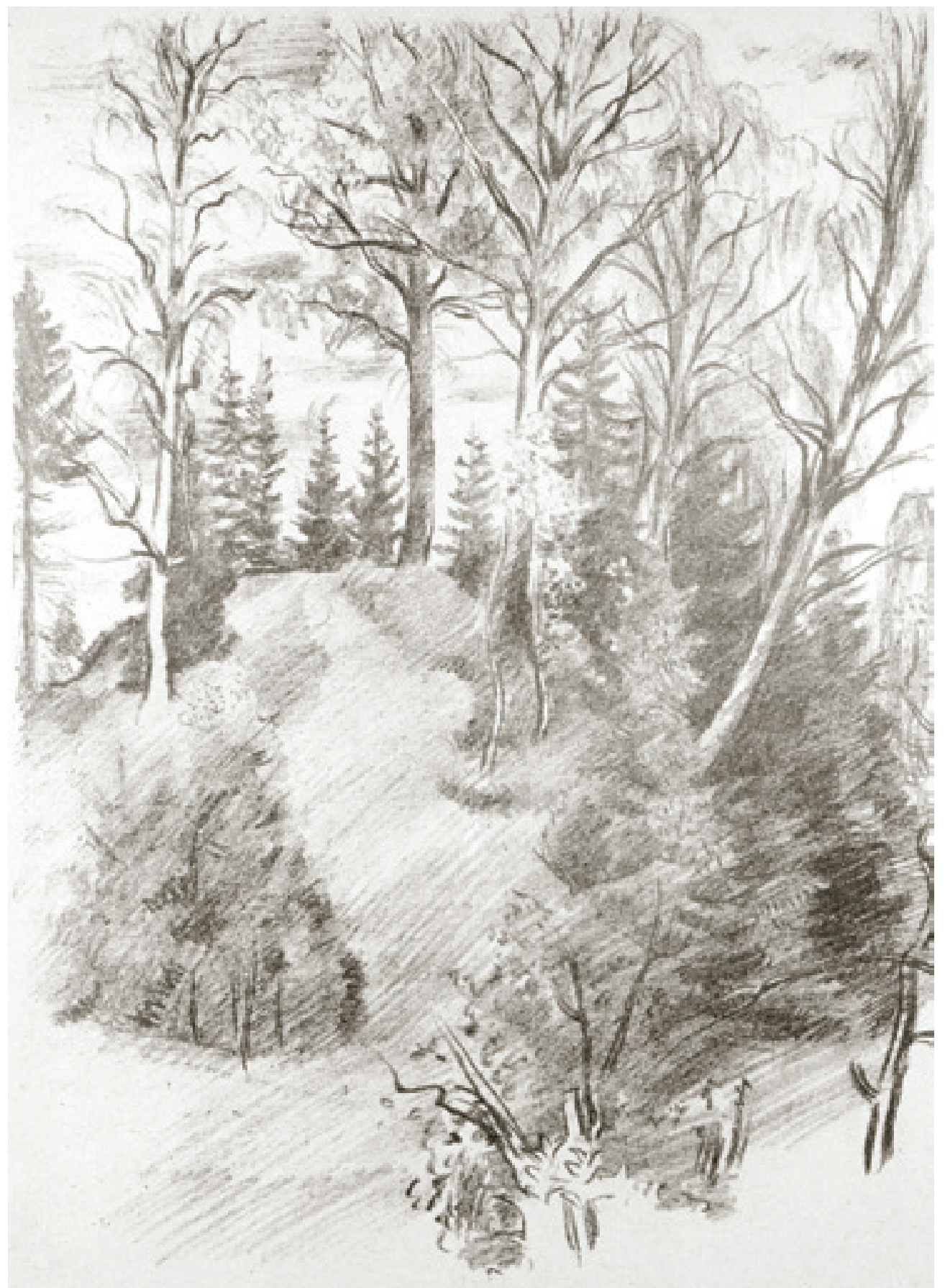

Gamle bjørketrær på en haug, 1922. Litografi. (Kat.nr. 170) 


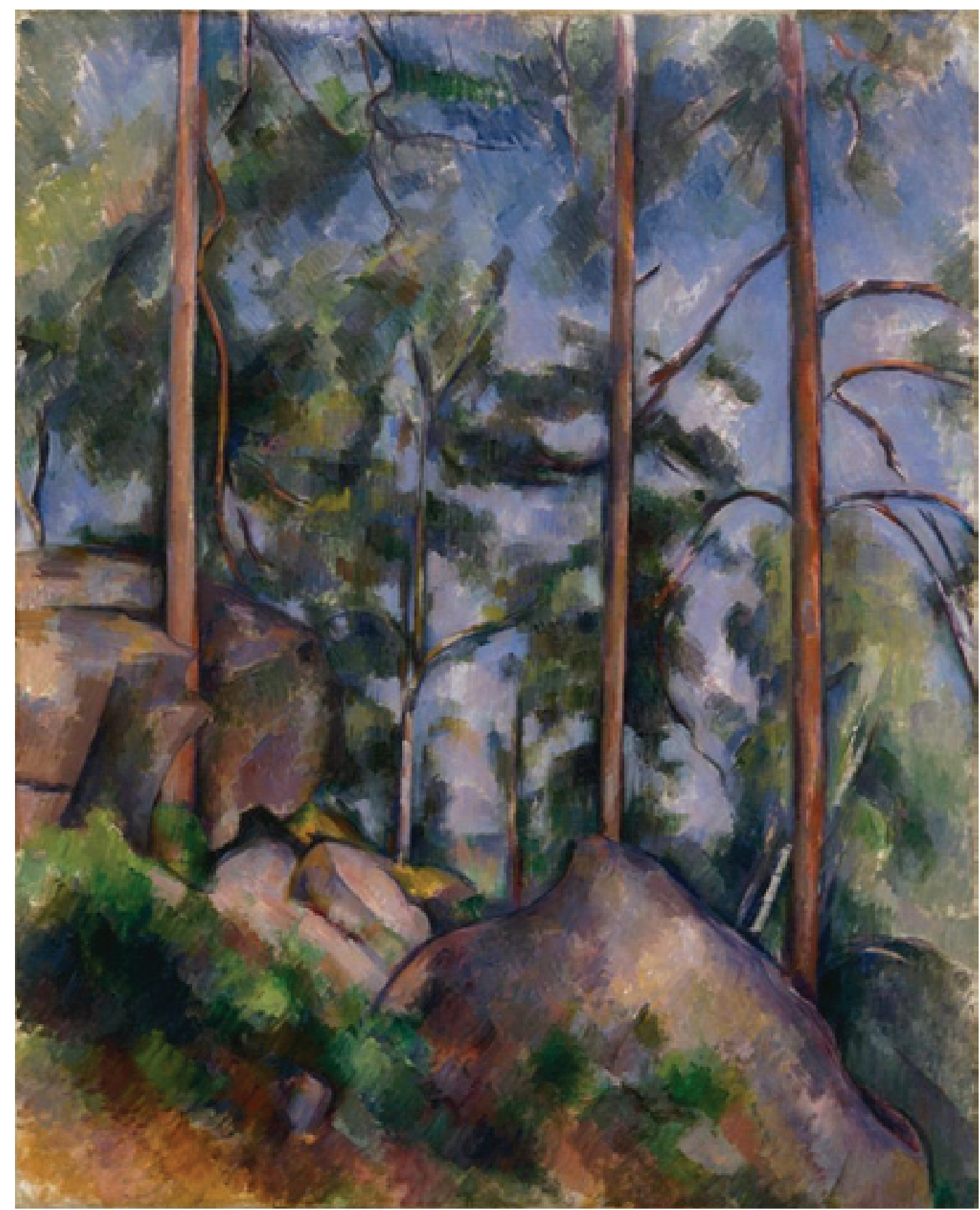

Furuer og steiner/Pines and Rocks (Fontainebleau?), ca. 1897. Olje på lerret, 813 x 654 mm. Digital Image (c (25.02. 2016) The Museum of Modern Art/Scala, Firenze. 
[sensation/sentir] av naturen. ${ }^{8}$ Naturlig nok uttrykkes dette på forskjellig vis, ut fra ideen om det sterkt personlige i kunstverket, som et resultat av en individuell respons på naturopplevelsen. I hans samtid ble Cézannes kunst beskrevet som radikal i formen, en karakteristikk som ikke i samme grad kan appliseres på Erik Werenskiolds 1900-tallskunst, verken i grafikken eller i maleriet. Noen radikal endring hadde Werenskiold heller ikke til hensikt. Han omformulerer impulsene fra Cézanne og setter dem inn i en norsk ramme.

\section{Naturen og det personlige uttrykket}

Naturen som direkte kilde for kunsten var altså et felles utgangspunkt for Werenskiold og Cézanne. For å gjøre den moderne kunsten klassisk og varig, skulle den ikke lages ved å imitere gamle mesteres verk, men den moderne kunstens nye klassisisme skulle finnes gjennom kunstnerens egen erfaring i opplevelsen av naturen. ${ }^{9}$ Ved å gå tilbake til kilden, «to the double origin, to nature and the self», skulle kunsten gjennomgå en foryngelse (rejuvenation). ${ }^{10}$ Tematikken behandles grundig $\mathrm{i}$ Richard Schiffs bok Cézanne and the End of Impressionism. Det vesentligste for Cézanne i prosessen med å innføre en ny og ung klassisisme «by way of nature» var, ifølge Schiff, å understreke den store betydningen som lå i individuell erfaring og følsomhet (sensation). ${ }^{11}$ Den ytre naturen skulle oppleves gjennom den indre naturen.

Individuell erfaring og personlig uttrykk var også vesentlig for Werenskiold, som uttalte at «den stærke personlige udfoldelsen er betingelsen for al stor blomstring». ${ }^{12} \mathrm{Med}$ radering og litografi fortsatte Werenskiold sine formale variasjoner over naturalismens lettleste og gjenkjennelige bildespråk.

Mens Werenskiold holder seg nært til et representerende bildespråk, er avviket fra det sette mer slående hos Cézanne. I sitt grundige studium av Cézanne skriver Richard Shiff om den tidlige resepsjonen av den franske kunstneren, i artikkelen «Seeing Cézanne», «[that] he was generally regarded as [...] one whose art was in some way simple and rudimentary, devoid of refinements and complexities of his materialistic, industrialized [...] society» ${ }^{13}$. Noe av dette påpeker også Maurice Denis når han sammenligner Cézanne med de samtidige modernistene Renoir og Manet: «Pictures of Cézanne seem like works

8 For begrepet sensation/sentir se note 11.

9 Schiff, Cézanne and the End of Impressionism: A Study of the Theory, Technique, and Critical Evaluation of Modern Art, 125.

10 Ibid., 125.

11 Schiff, Cézanne and the End of Impressionism: A Study of the Theory, Technique, and Critical Evaluation of Modern Art, Chicago og London 1984, 125. Begrepet sensation/sentir var grunnleggende for Cézannes estetikk, og karakteriserte en individuell, følelsesmessig opplevelse eller erfaring, som per definisjon var unik for hvert individ. "Le littérateur s'exprime avec abstractions, tandis que le peintre concrète au moyen dessin et de la couleur ses sensations, ses perceptions.» Paul Cézanne i brev til Emile Bernard, datert Aix, 26. mai 1904. Gjengitt i Stephanie Buck et al. (red.), The Courtauld Cézannes, London: The Courtauld Gallery og Paul Holberton Publishing, 2008, s. 152. «Votre besoin de trouver un point d'appui moral, intellectuel dans des oeuvres qu'on ne surpassera pas assurément, vous met sur le perpétuel qui vive, sur la recherche incessante des moyens entreperçus qui vous conduiront sûrement à sentir sur nature vos moyens d'expression, et le jour où vous les tiendrez, soyez convaincu, que vous retrouverez sans effort et sur nature les moyens employés pas les quatre ou cinq grands de Venise, -..» Paul Cézanne i brev til Emile Bernard, datert Aix, 23. desember 1904. Gjengitt i Stephanie Buck et al. (red.), The Courtauld Cézannes, London: The Courtauld Gallery og Paul Holberton Publishing, 2008, 158.

12 Werenskiold, sitert i Aubert, Norsk kultur og norsk kunst, 192.

13 Schiff, «Seeing Cézanne», 771. 
of another period, no less refined but more robust than the most vigorous efforts of the Impressionists.» ${ }^{14}$ Det samme som Werenskiold så, og karakteriserte som «sunt og bredt», i motsetning til det tynne og virtuose som han så hos Manet. ${ }^{15}$

Inntrykket som denne «sunne» og «brede» malemåten ga, fikk Maurice Denis til å karakterisere Cézannes formspråk som gaucheri, som «klossete» og «fordreid». ${ }^{16}$ Forklaringen på det «fordreide» og «klossete» kan være at Cézanne valgte flere ståsteder å se motivet fra, og at han oppsøkte motivet gjentatte ganger i en slags endeløs søken. Roger Fry skriver om Cézanne: «For him, as I understand his work, the ultimate synthesis of a design was never revealed in a flash; rather he approached it with infinite precautions, stalking it, as it were, now from one point of view, now from another, and always in fear lest a premature definition might deprive it of something of its total complexity. For him the synthesis was an asymptote towards which he was for ever approaching without ever quite reaching it; it was a reality, incapable of complete realization. $»^{17}$ George Hamilton beskriver dette som «the entire pictorial surface of a Cézanne is the sum of continuous perceptions of space in the mode of time. $\rangle^{18}$ Cézannes formspråk kan også forklares ut fra Henri Bergsons idé knyttet til persepsjon. Han sier at våre synsinntrykk ikke bare inneholder det aktuelle øyeblikket, men også alle tidligere erfaringer. «In fact, there is no perception which is not full of memories. With the immediate and present data of our senses we mingle a thousand details out of our past experience. In most cases these memories supplant our actual perceptions, of which we then retain only a few hints, thus using them merely as 'signs' that recall to us former images.» ${ }^{19}$ Med utgangspunkt i Bergson kan man si at det «klossete» og «fordreide», det «brede» og «sunne» i Cézannes bilder representerer en oversettelse av naturens og minnets kompleksitet. Bearbeidelsen av det sette kan leses som en slags urolig og diffus virkning i deler av motivet. Den diffuse virkningen opptrer både i statiske elementer, som for eksempel i hus og steiner, og i vegetasjon som potensielt kan bevege seg med vinden. I Cézannes tilfelle blir dette til summariske og mindre detaljerte strukturer på lerretet.

I Werenskiolds grafikk finner vi også en form for summariske framstillinger. Sammenlignet med seg selv går Werenskiold fra en detaljert naturalisme, en ytre «objektiv» registrering av virkeligheten på 180o-tallet, til en noe mindre detaljert presentasjon av naturinntrykk i sin grafikk på 1900-tallet. Dette ses både i enkeltelementer og i komposisjonen som helhet. Werenskiolds etsning Lyse sommer fra 1914 viser utsikten fra Gilje. I forgrunnen rager en furu opp fra den lavere vegetasjonen omkring. Den summariske framstillingen gir treet en rasjonell og nøktern form som baserer seg på en syntetiserende forståelse av greiner og trekrone. De diagonale skraveringene oversetter grønne og blå nyanser til valører i gråtoneskalaen, fra helt sort til lyst grått. I forgrunnen oppstår et urolig felt, en nitid beskrivelse av variasjoner i vegetasjonens tekstur, og ikke som hos Cézanne hvor det urolige oppstår som et resultat av hans mange ståsteder i forhold til motivet.

Fra sitt hjem på Lysaker hadde Werenskiold en utsikt som har visse likhetstrekk med det vi finner i Cézannes motiv Mont Sainte-Victoire og viadukten datert 1882-1885. Her ses landskapet i Vallée de L'Arc i Aix-en-Provence. Med karakteristiske penselstrøk presenterer Cézanne utsikten mot Mont Sainte-Victoire med furuen sentralt i forgrunnen. Den diffuse formbeskrivelsen hos Cézanne ses særlig i huset og vegetasjonen i forgrunnen og husklyngene i mellomgrunnen. For å skape

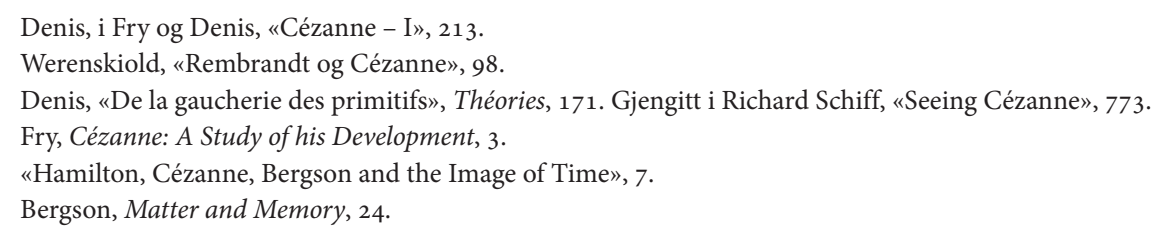




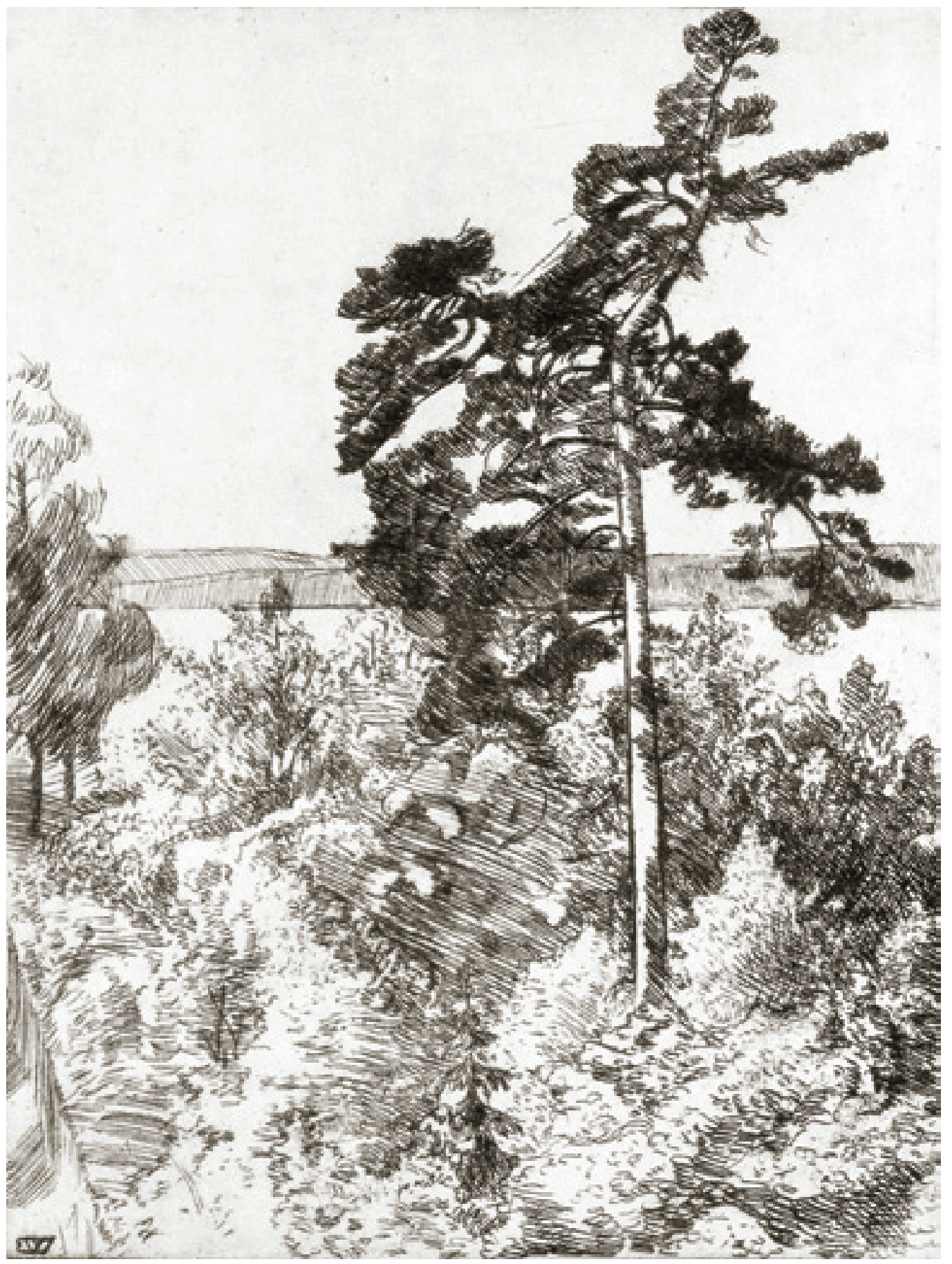

Lyse sommer, 1914. Streketsning. (Kat.nr. 59) 


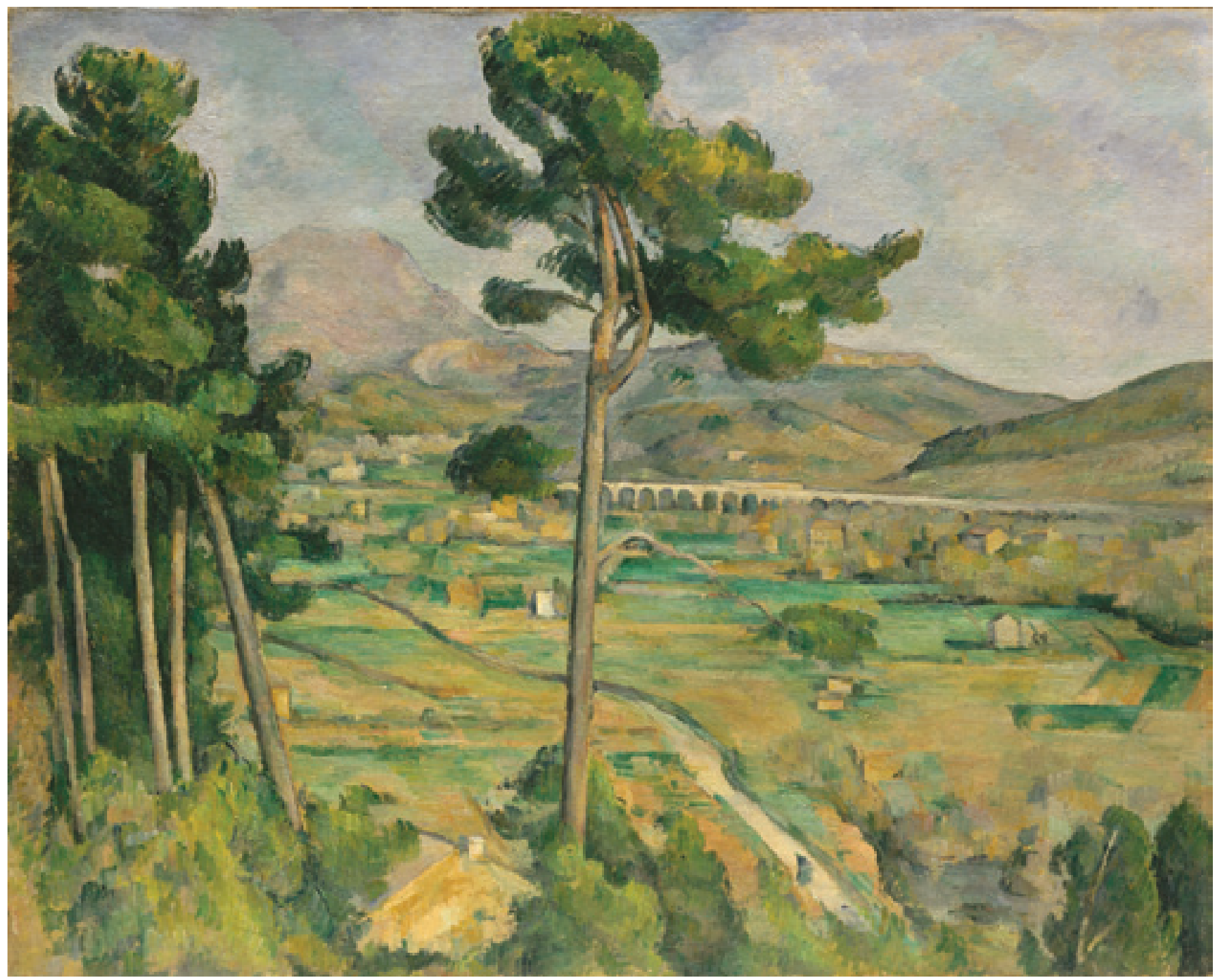

Mont Sainte-Victoire og viadukten, 1882-1885. Olje på lerret, 654 x 816 mm. (c) Metropolitan Museum of Art, New York.

balanse i sin komposisjon har Werenskiold valgt å plassere treet svakt til høyre for midtlinjen, mens Cézanne i sitt maleri har valgt en tilsvarende plassering til venstre. Siden etsningen speilvendes i trykkeprosessen, er treet på trykkplaten plassert på samme sted som på Cézannes lerret. Komposisjonene stabiliseres av vertikale stammer og horisontale linjer. Horisontallinjer dannes henholdsvis av strandlinjen og de to åskammene på motsatt side av Oslofjorden hos Werenskiold, og av viadukten hos Cézanne. 
Selv om maleri og etsning er to teknisk helt ulike medier, kan en malerisk virkning oppnås i begge. Variasjonen $\mathrm{i}$ penselføringen hos Cézanne går fra det diagonale i den store furuen og beveger seg mot vertikale strøk i treklyngen til venstre. I landskapet mellom furu og fjell finner vi horisontale strøk, og fjellet St. Victoire er malt med strøk i ulike retninger. I noen områder går de lyse fargenyansene over i hverandre, uten at strøkene er synlige. Den personlige variasjonen i penselstrøkene hos Cézanne svarer til Werenskiolds bruk av etsenålen.

Innenfor en større ramme kan vi ved hjelp av sammenligningen mellom Werenskiold og Cézanne konkretisere forskjellen mellom sentrum og periferi i europeisk kunst på begynnelsen av forrige århundre. Modernismens overordnede krav om originalitet og individuelt uttrykk på den ene siden og behovet for å opprettholde standarder satt av fortiden på den andre, gir seg til kjenne på forskjellig vis. Til forskjell fra naturalismen i Frankrike kan naturalismen i Norge ikke slippe taket. 



\section{Erik Werenskiolds egne forutsetninger: Fra illustratør til utøvende grafiker}

Før Erik Werenskiold begynte med grafikk, var han kjent med andre måter å publisere og mangfoldiggjøre sine kunstverk på. Hans store produksjon av illustrasjoner til litterære tekster hadde i perioder tatt store deler av hans tid fra han laget sine første eventyrtegninger i 1878 og fram til 1904 da han avsluttet sin karriere som illustratør med tegningene til Familien på Gilje.

Werenskiold var opptatt av bildemediets og litteraturens dannelsesaspekt. Det var viktig å bidra til at folk flest skulle få tilgang til bokutgivelser generelt og til illustrerte bøker spesielt. Flere av bokutgivelsene som han illustrerte, oppfylte en slik demokratiserende idé. Som illustrasjoner ble tegningene spredt i store opplag og gjort tilgjengelig gjennom en relativt lav pris. ${ }^{1}$ Den første utgivelsen som inneholdt illustrasjoner av Werenskiold, var Norske Folke og Huldreeventyr som kom ut høsten 1879. Senere fulgte Eventyrbog for Børn på 1880-tallet og Nordahl Rolfsens Loesebog for folkeskolen på 1890-tallet, før folkeutgaven av Snorre Sturlasons Kongesagaer kom i 1899. Eventyrillustrasjonene ble trykt som xylografier skåret av blant andre Rasmus Frederik Hendriksen (1847-1938) i København, mens tegningene i kongesagaene var klisjétrykk.

Eventyrillustrasjonene var årsaken til at Erik Werenskiold allerede som 23-åring fikk anledning til å markere sin posisjon på den «svart-hvite» kunstarenaen; kontakten med og oppdraget fra eventyrsamleren Peter Christen Asbjørnsen (1812-1885) i 1878 resulterte i en stor produksjon av illustrerende tegninger, så oppsiktsvekkende utført at de, i hvert fall her i Norden, ledet til en ny og epokegjørende forståelse for hva god illustrasjonskunst kunne dreie seg om. I gjennomføringen av sitt første store illustrasjonsoppdrag kunne Werenskiold gi form til sin oppfatning av innholdet i den hjemlige og folkelige fortellertradisjonen som eventyrene representerte. En tradisjon som var i ferd med å forsvinne på denne tiden, noe som var foranledningen til Asbjørnsens engasjement for å samle dem i trykte utgaver.

Eventyrillustrasjonenes realistiske og folkelig anlagte bildespråk ble starten på visualiseringen av det norske. ${ }^{2}$ «[...] det var gjennom arbeidet med eventyrillustrasjonene at Werenskiold utviklet sin nasjonale stil. For ham ble det et mål at hans kunst skulle være uttrykk for en særegen norsk tradisjon, et mål som ble klart for ham allerede i München, og hadde vi ikke

$1 \quad$ Østby, Erik Werenskiold. For at tegningene skulle kunne trykkes, ble for eksempel eventyrtegningene manuelt eller fotomekanisk overført til trestokken og trykt som xylografier risset av xylografene F. Hendriksen og H.P. Hansen i København, av Borch som arbeidet hos xylograf Hecht i München og Closs i Paris (trestikk med tone; «Trollene på Heidalsskogen»), 46-47.

2 Berg (et al.), «Maleriet 1870-1914», 130. 


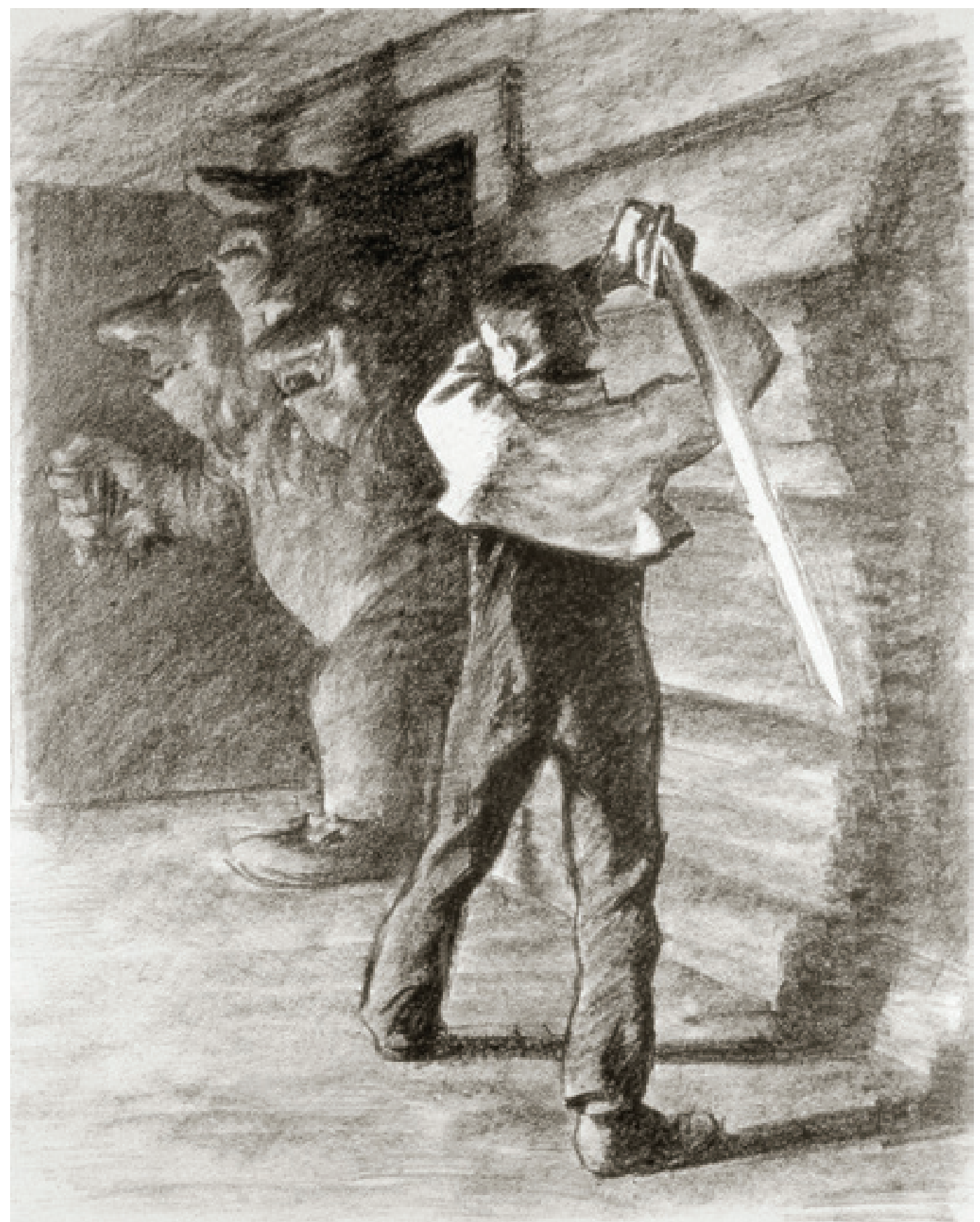

Gutten som hugger hodene av trollet II, 1930. Litografi. (Kat.nr. 207) 


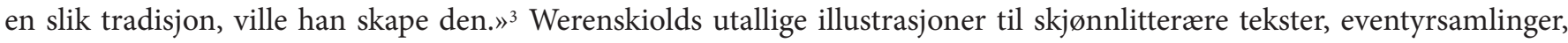
lesebøker og sagalitteratur ble kulturelle referanser for folk i Norge på slutten av 1800- og langt inn på 1900-tallet. Det finnes imidlertid få eksempler på eventyrmotiver blant Werenskiolds raderinger og litografier, og kun ett motiv som kan knyttes direkte til eventyrene. Pennetegningen Gutten som hugger hodene av trollet ble litografert i 1930, og var opprinnelig en illustrasjon fra 1884 til eventyret «Soria Moria slott» utgitt i den tidligere nevnte Eventyrbog for Børn. ${ }^{4}$ Nå var da heller ikke den nasjonale fortellingen det primære innholdet i Werenskiolds grafikk.

Erik Werenskiold ga form til den norske folkekarakteren og den norske naturen. Jørgen Moe (1813-1882) og Peter Christen Asbjørnsen systematiserte «norskhets-kriteriene» og utla dem som «indre Bevis på vore Eventyrs Hemlighed».5 Folkeeventyret framsto som et originalt nasjonalt kulturprodukt med linjer bakover til sagatid og middelalder gjennom natur- og miljøskildringer, personkarakteristikker og fortellermåte. «Det er et internasjonalt faktum at eventyrtradisjonen i et land vil avspeile både landskapet der, skikker, levekår og sosiale relasjoner. [...] Slik Moe så Askeladd-figuren hadde han en dyp erkjennelse av egen kraft, som aldri lot ham gå under i kampen mot overmakten, slik som «der Dummling», hans tyske parallell stundom gjør. Typisk for Askeladden er «den dype Forborgenhed, hvori hans naturlige Overlegenhed holdes, indtil han med Et træder frem». I så måte har han paralleller til sagalitteraturen, og er et minne om den. Det er i ham «en

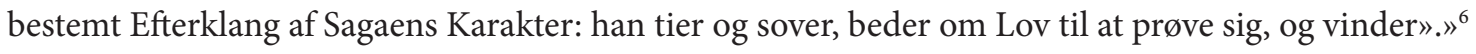

Bare et land med en egalitær kultur kan gi disse karakterene en romslig aksept, konkretisert gjennom Werenskiolds gjengivelse av en godslig øvrighetsperson i tegningen av kongen i eventyret «Herreper» og den ivrige fattig-gutten Espen Askeladd som ikke lar seg stoppe $\mathrm{i}$ «Prinsessen som ingen kunne målbinde». Werenskiolds karaktertyper, natur- og miljøskildringer oppfyller Moes utlegning uten at det slår over i det følelsesladde og altfor romantiserende og stemningsfulle. Denne tilsynelatende nøkterne tilbakeholdenheten i eventyrets fortellerstil er en eiendommelig uttrykksmåte som harmonerte godt med naturalismens refererende bildespråk. I gjengivelsen av begivenheter og skjebner røper allikevel eventyret et subjektivt engasjement når det gripende holdes på avstand, eller gis en humoristisk form. ${ }^{7}$ Dette forholdet mellom nøkternhet og alvor og subjektivt engasjement kan gis gyldighet i hele Werenskiolds kunstnerskap.

Illustrasjonsoppdragene la i lange perioder beslag på store deler av Werenskiolds arbeidskapasitet. Tekstene som Werenskiold illustrerte var historieverk, sagalitteratur og folkediktning. Denne litteraturen inngikk som et ledd i det nasjonale byggeprosjektet. «I tiden etter 1905 var diskusjonen om norskhet og arbeidet med å formidle det genuint nasjonale, utslag av bekymring for å miste forbindelseslinjene bakover til bygdekulturen og historien.» ${ }^{8}$

Det nasjonale tankegodset og den positivistiske vitenskapsteorien dominerte det idémessige grunnlaget i politikk og kulturliv på slutten av det 19. århundre. Disse strømningene påvirket Erik Werenskiold som illustratør og grafiker. Illustrasjonene skulle ut fra den positivistiske ideen helst være «korrekte», de skulle vise hendelsenes klimaks, og den kunstneriske friheten skulle underlegges empirien. Et nitid arbeid med innhenting av historiske opplysninger og studier av

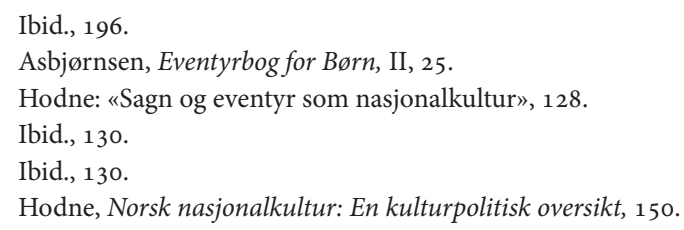


bygninger, husgeråd og landskap var nødvendig for å tilfredsstille de kravene som dette idégrunnlaget stilte. Allikevel kunne Werenskiold med sitt spesielle observasjonstalent og sine store tegneferdigheter utvikle en form for frihet i forhold til det «korrekte». I sin suverene ferdighet i tegningen kunne han tillate seg å ta betrakteren med på sine selektive og redigerte utvalg av virkeligheten. Med syn for de små nyansene som tar hendelser og gester på kornet, kunne leseren nikke gjenkjennende til opplevelser og personkarakteristikker i Werenskiolds bildespråk. Werenskiolds illustrasjoner ble historier i historien. Hans imponerende bidrag til historiefortellerkulturen vitner om et behov for å kommunisere med publikum, med lesere og betraktere. I 1902 uttrykte han seg på denne måten: «Ti det er i det daglige liv de først og fremst skal se noget andet end det trivielle. Kan de gjennem billeder lære at faa syn for stemningen i naturen og en sympatisk forstaaelse av menneskene, eller lære at more sig over at de er saa rare, saa vilde jo livet formildes og vinde mer inhold.» $\aleph^{9}$ Werenskiolds lett leselige bildespråk i kombinasjon med et folkelig utvalg av bøker kan avleses som folkelige og demokratiserende spor i denne formen for trykk.

Utgivelsen av Snorres Kongesagaer er et godt eksempel på en boklansering som utviklet seg til et prosjekt med demokratisk hensikt. Werenskiolds arbeid med Snorre-tegningene varte i tre år, fra 1896 til 1899. ${ }^{10}$ Den opprinnelige intensjonen var å trykke to forskjellige utgaver: en praktutgave og en samtidig folkeutgave. Folkeutgaven var utstyrt på samme måte som praktutgaven, i kvartformat med to farger, men manglet siderammer for hver enkelt saga. ${ }^{11}$ Kravet til historisk riktighet ble ivaretatt av historieprofessor Gustav Storm, og av Werenskiold som var formann i kunstnernes sensurkomité.

De kunstnerne som fikk i oppgave å illustrere Snorre, var stilt overfor en helt ny oppgave i norsk kunst. Dette var den første illustrerte bokutgivelsen som helt fra det kunstneriske til det tekniske skulle produseres i Norge. Det hadde også tidligere blitt trykt utgaver av Snorre, men disse hadde vært avhengig av utenlandsk faglig bistand. Forlagssjef J.M. Stenersen og hans kollegaer hadde gitt seg i kast med et verk som skulle være norsk tvers igjennom. Intensjonen var god, men klutepapiret måtte hentes fra den svenske fabrikken «Klippan», og typene var tyske. I tillegg til praktutgaven og folkeutgaven fra 1899, ble det utgitt en billig «Nationaludgave» i 1900, med økonomisk støtte fra Stortinget. Mottoet for storsatsningen ble: «Snorre inn i alle Hjem!» For å understreke at denne utgaven skulle ha et stort nedslagsfelt, ble det i søknaden til de folkevalgte understreket at den skulle utgis på både riksmål og landsmål.

Tegningene til Snorre ble utført i en strekteknikk som ble tilpasset papir og trykkemetode. Xylografiet som lenge hadde vært den mest brukte trykkemetoden for overføring av tegninger til bokillustrasjoner, hadde nå på begynnelsen av 1900-tallet blitt detronisert, og nye fotomekaniske reproduksjonsmåter hadde overtatt. Den fotomekaniske overføringen innebar at Werenskiold og de andre kunne slippe å tegne på overføringspapir med spesielt tilegnet tegnemateriell. I stedet kunne de bruke vanlig penn, kritt eller blyant på alminnelig papir. Tegningene ble overført til sinkplater som siden ble etset. Werenskiold var ofte til stede i trykkeriet og fulgte med på overførings- og etsningsarbeidet. For ham var det særdeles viktig å ivareta tegningens karakter slik at den ikke ble forringet. Det var sinkograf F.B. Jensen som sto for etsningsarbeidet, en kunstnerisk innstilt håndverker og en god venn av Werenskiold. Med gjensidig respekt og felles forståelse for produktet ble

9 Werenskiold, «Skjønhetssans», 91

10 Østby, Erik Werenskiold, 214.

11 Werenskiold var ikke alene om å gjennomføre det store illustrasjonsarbeidet. Seks kunstnere delte prosjektet etter forslag fra Werenskiold. De øvrige bidragsyterne var Christian Krohg, Eilif Peterssen, Halfdan Egedius, Wilhelm Wetlesen og Gerhard Munthe. 
samarbeidet en fruktbar og lærerik prosess for Werenskiold. Vi kan anta at det nære samarbeidet med sinkograf Jensen og befatningen med etsning også kan ha hatt stor betydning for Werenskiolds eget arbeid som grafiker, siden etsning, om enn i en annen form, ble den grafiske metoden han først valgte å gi seg i kast med. I nært samarbeid med kjemigrafer og trykkere føyet boken seg inn i en tradisjon med forbindelser til folkekunst og håndverk.

Arbeidet med sagaillustrasjonene innebar en kunstnerisk og tidsbegrenset intens prosess med studier, tegning og trykketeknisk arbeid. Dette kan også ha hatt betydning for Werenskiolds senere arbeid som grafiker. Illustrasjonenes enestående og spesielle tekstrelaterte karakter vil riktignok ikke kunne gjenfinnes i kunstgrafikken, men hans rasjonalisering med virkemidlene og strenge redigering av uttrykket kan ses igjen i grafikkens ofte velorganiserte og selektive virkelighetsutsnitt.

Illustrasjonene til Familien på Gilje ble påbegynt i 1891 og avsluttet først i 1904. Skildringen av offisersfamilien på Gilje og Jonas Lies «merkelig bestemte oppfatning af alle personene» ${ }^{12}$ lå godt til for illustrasjonskunstneren Werenskiold. «I intet verk har han git sig selv saa helt: saa meget av sit fine blik paa livet, saa meget av sit eget fine sinds poesi, saa meget av sit eget livs erfaring i sorg og i glæde. [...] Werenskiold [har] hat at gjøre levende, gjennom historiske studier av tidsmiljøet og kostymet, tider han aldrig selv har set. Men studiet er gjemt i hans kunst som om han hadde været øienvidne til det alt sammen.» ${ }^{13}$ Andreas Aubert hevdet at Familien paa Gilje i likhet med eventyrene og Snorre, ville erobre Norge, og at verden der ute vil lære et stykke Norge å kjenne som noe fortrolig og nært. ${ }^{14}$

Med hovedtyngden på eventyrverdenens tidløse parabler, sagalitteraturens bundethet til fjernere tider og til slutt Giljetegningenes skildring av den nære fortiden, hadde Werenskiold fullført sitt store arbeid som illustratør. Med originalgrafikken gikk han løs på et arbeid som i all hovedsak visualiserte hans egen samtid. Med den formidlende funksjonen som Werenskiolds masseproduserte bilder hadde, må den på et dypere strukturelt plan for datidens mennesker ha understreket en form for nasjonal kontinuitet mellom århundrene.

\footnotetext{
Østby, Erik Werenskiold, 107.

Aubert, Norsk kultur og norsk kunst, 196.

Ibid., 197.
} 



\section{KAPITTEL 5}

\section{Distribusjon og utstillinger}

Med sine forskjellige kunstneriske uttrykksformer, maleri, illustrasjoner og tegning, var Werenskiold allerede godt kjent for et stort publikum da han utvidet sitt kunstneriske repertoar til også å omfatte raderinger og litografier. Hans solide navn og rykte hadde forberedt et marked og gjort det attraktivt for publikum å gå til anskaffelse av et originalt Werenskiold-verk i form av et grafisk blad. Hensikten med mangfoldiggjøring er å gjøre kunstverk fysisk og økonomisk tilgjengelig. Mangfoldiggjøringsbehovet kan være motivert av et politisk maktapparat for å fungere i propagandaens tjeneste, eller kan ha oppstått som en demokratiserende idé knyttet til kunstnerens frie utfoldelse innenfor en demokratisk ramme. I denne siste og aktuelle konteksten blir mangfoldiggøøring og demokratisering gjensidig forsterkende prinsipper. Werenskiolds raderinger og litografier kan betraktes som en fortsettelse av et slags demokratiseringsprosjekt som startet med bokillustrasjonene. Grafikkens fysiske tilgjengelighet var knyttet til utstillinger i gallerier, museer og kunstforeninger.

\section{Utstillingssteder: Først ute, så hjemme}

Den markedsmessige innstillingen til grafikken betydde at Werenskiold raskt kom ut med sine første etsninger. Allerede i november 1909 ga han til kjenne i et brev til Bernt Grønvold at han gjerne ville selge grafikk, overraskende nok ikke på den hjemlige kunstarenaen, men på Secessionen i Berlin, hvor han stilte ut fire verk. ${ }^{1}$ I Werenskiolds håndskrevne notater går det fram at Lysakerbrua, vinter (1908-1909) ble solgt for 80 riksmark, Nansens hus, Polhøgda (1909) for 100 riksmark, Kullsjau (1909) og To gutter (1909) for 60. For å fastsette prisen på hvert enkelt verk hadde Werenskiold rådført seg med Johan Nordhagen, som var godt orientert i det nasjonale og internasjonale grafikkmarkedet. I tillegg til de etsningene som ble vist på Secessionen i Berlin i 1909, gikk flere verk til Tyskland. Syv motiver ble kjøpt av Kgl. Kupferstichkabinet i Dresden. ${ }^{2}$

Dette ser ut til å være de samme som ble sendt til Grønvold 30. juni 1909. ${ }^{3}$ Titlene er Høyfiell (1908-1909), Den engelske flàte (1908-1909), Nansens hus, Polhøgda (1909), Kullsjau (1909), To gutter (1909), Venninner (1909) og Løpende troll (1909). Disse titlene stemmer overens med de raderingene som er ført opp i museets inventarlister (Staatliche Kunstmuseums, Dresden). I den samme inventarlisten finnes i tillegg raderingen Furutrcerne (1910) innkjøpt i 1922. Ellers gir Werenskiolds grafikkoversikt

Brev fra EW til BG datert 5.11. 1909.

Raderingene ble sannsynligvis sendt den 6.6. 1909 til direktør ved samlingen M. Lehrs. Opplysningen er fra Werenskiolds håndskrevne notater og verksoversikt.

Brev fra EW til BG datert 1.7. 1909. 


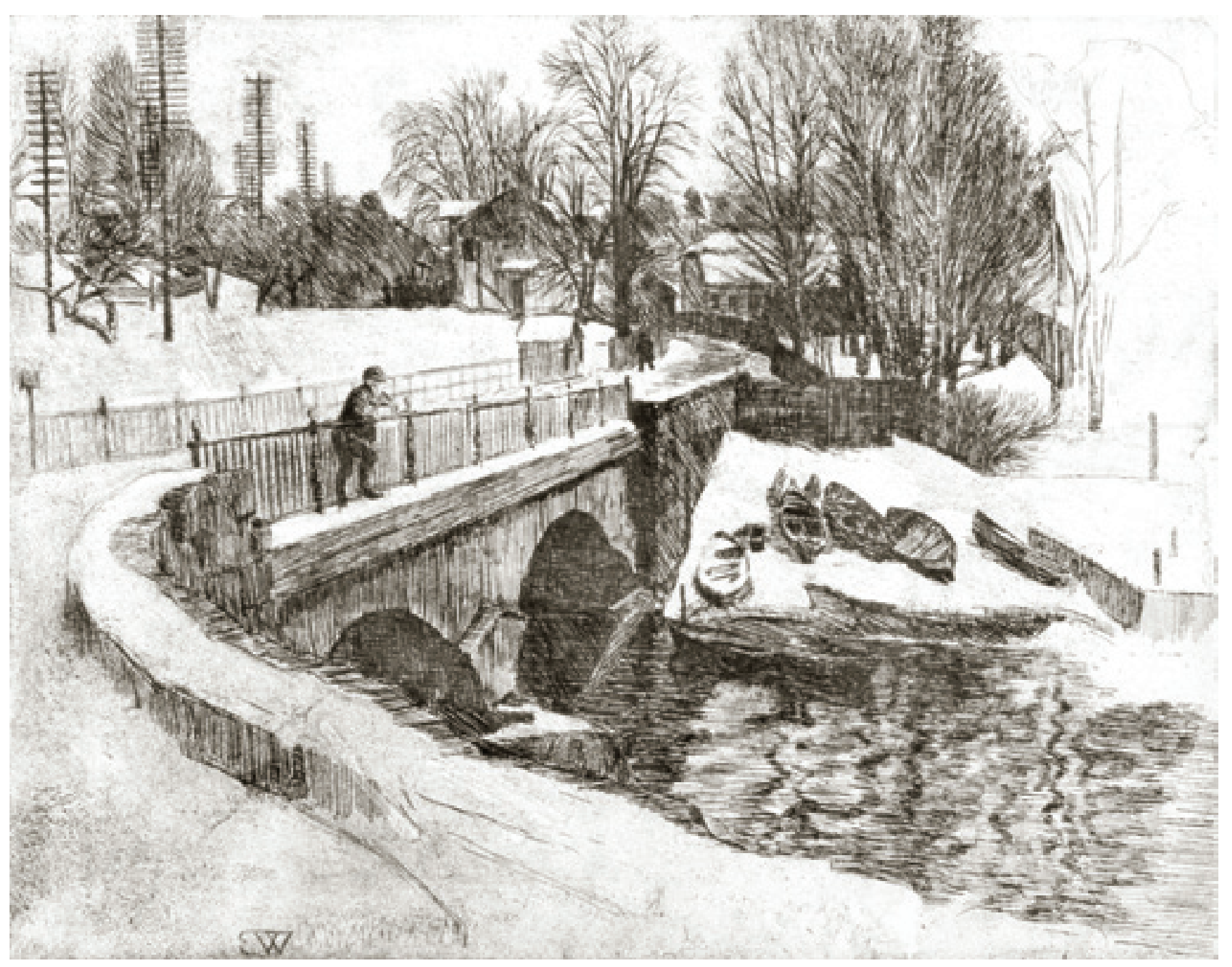

Lysakerbrua, vinter, 1908-1909. Streketsning. (Kat.nr. 7)

opplysninger om at de tidligste etsningene ble tilbudt til større samlinger for grafisk kunst ved museer i Bremen, Frankfurt, München, Hamburg, Breslau, Köln og København. Ved en utstilling i Helsingfors Konstförening i 1911 deltok han med hele 16 raderinger.

Werenskiold benyttet seg også av muligheten til å ha grafiske blad i kommisjon hos en rekke kunsthandlere. Av hans notater går det fram at han med vekslende hell fikk solgt sine arbeider i byer som Leipzig, Dresden og Hamburg, Stockholm og Göteborg. ${ }^{4}$ 


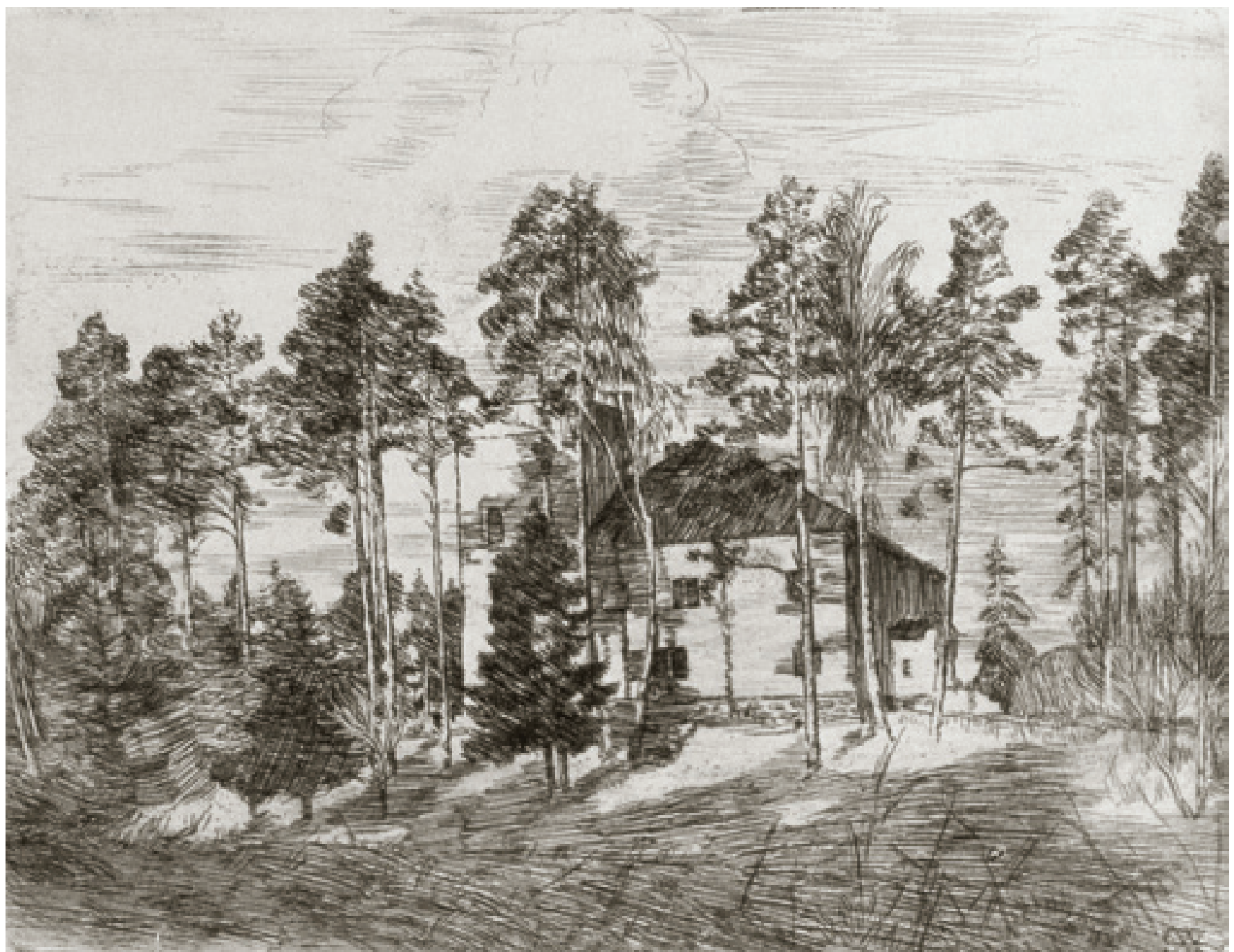

Nansens hus, Polhøgda, 1909. Streketsning. (Kat.nr. 9)

At de tidlige grafiske verkene først ble sendt utenlands, kan begrunnes med at verk som oppnår anerkjennelse $\mathrm{i}$ et etablert, kompetent miljø, øker sin symbolske verdi. Denne symbolske kapitalen innehas av aktører «som byter det symboliska kapitalet mot ekonomisk hård-valuta».5 Med innehavere av denne «kapitalen» menes kunstnere, gallerieiere, kritikere og kunstsamlere. En viktig funksjon i dette systemet hadde, for Werenskiolds del, hans venn og mesen i Berlin, Bernt Grønvold, og mesenene Axel Heiberg og Rasmus Meyer her hjemme, rådgiveren Johan Nordhagen, det kulturelle miljøet som omga

5 Burén, Det mångfaldigade originalet, 151. 
kunstneren, aviskritikere, forleggere, gallerieiere, kunstmuseer og grafikkforeningene som ble opprettet med det ene målet for øyet å gi grafikken så gode vekstvilkår som mulig både praktisk og økonomisk her hjemme.

Første gang Werenskiold viste sine raderinger i en tradisjonell kunstutstilling her hjemme, var i 1914. Da ble et stort antall vist i Kristiansands Kunstforening. ${ }^{6}$ Og i oktober 1915 ble raderingene vist i Kunstnerforbundet. På utstillingsfronten hadde raderingene banet vei for litografiene. Allerede ett år etter oppstarten hadde han rukket å lage flere motiver som han stilte ut i Kunstnerforbundet i oktober 1918.

Grafikk som «brødkunst» er ikke til å stikke under stol, heller ikke for Werenskiolds del. Grafikken kom da også til å bli en god inntektskilde for ham. En sterkere markedsmessig tilpasning kan anes idet han går over til litografiet som er særlig egnet for store opplag. Dessuten ble litografiene trykt på papir av forskjellige kvaliteter, «alminnelig papir, bøttepapir og japanpapir», noe som gjorde det mulig å tilby grafiske blad med identiske motiver til forskjellige priser. ${ }^{7}$ Dette var en vanlig markedsrettet praksis. Japanpapiret hadde best kvalitet og ga dermed det mest eksklusive trykket. En parallell praksis finnes når det gjelder bokutgivelser. Snorre kom for eksempel i en praktutgave som henvendte seg til et kresent publikum, en folkeutgave som henvendte seg til et bredere borgerskap, og endelig en «Nationaludgave» for folk flest. Og på samme måte som for grafikken kunne det mer eller mindre eksklusive reguleres gjennom størrelsen på opplaget. Werenskiolds grafikkopplag ser ut til å ha variert sterkt. Det eksisterer Werenskiold-raderinger som ifølge hans håndskrevne oversikt kun finnes i ett eller et par eksemplarer, og som ut fra dette kan regnes som mer verdifulle enn trykk i større opplag. Bevisstheten rundt denne problematikken kommer fram i en kommentar til to av hans tidligste etsninger, Lysakerbrua, vinter, (1908/09): «Ødela en raderplate, Lysakerbroen, vinter. Dessverre. Har bare noen få avtrykk, liksom av trollet - der har jeg bare ett. Det er vel fornuftig at gjemme disse få, om jeg skulle få et navn som raderer, ble de kanskje verdifulle.» ${ }^{8}$

Men uansett opplagsstørrelser ble det viktig å få grafikken ut også til et norsk kunstpublikum. Erik Werenskiold nøt godt av en viktig aktør i det tidlige grafikkmiljøet i denne sammenhengen. Norsk Forening for Grafisk Kunst kom på banen i 1908 og jobbet for spredning av og kjennskap til grafikk, først og fremst som kunstnerisk uttrykksform, ved hvert år å utgi en mappe med verk av norske grafikere. I 1910 valgte NFfGK å presentere Werenskiolds etsning Bygen (1910) for sine abonnenter som allerede hadde passert $200 \mathrm{i}$ antall. Motivet er som i flere andre tidlige etsninger hentet fra Lysaker. Det viser et utsnitt av Oslofjorden sett fra Werenskiolds bosted, Gilje, med utsikt mot neset hvor Nansens første bolig "Godthåb» lå. Erik Werenskiold var senere representert i NFfGKs årsmapper i 1918 og 1935, og etter sin død i 1939, 1945 og 1946.

Werenskiolds etablerte posisjon som kunstner ga grafikken en rask og stor spredning, fra den helt nære hjemlige arenaen, til de europeiske storbyene og over Atlanterhavet til USA. I slutten av oktober 1928 mottok Werenskiold en invitasjon fra The print Club of Philadelphia, USA. Innbydelsen ble sendt via sekretær i Foreningen Original Træsnitt, H. Lundstrøm, i Stockholm. Werenskiold pakket to raderinger til forsendelse: Vinternatt (1911) og sannsynligvis Trollpakk I (1913). Året etter var det meningen å delta med tre litografier ved en utstilling ved The Print Department, Art Institute of Chicago, men det skulle vise seg at postgangen kom til å ta for lang tid, og litografiene ble aldri sendt. Litografiene som var tiltenkt Chicago-utstillingen, var Vinter oppi bakken (1928), Tømmerlasset (1928) og Den hvite dame (1929).

6 Ifølge Werenskiolds håndskrevne notater og grafikkoversikt, 47 ulike motiver.

7 Dette framgår av Werenskiolds håndskrevne notater og grafikkoversikt og utstillingskatalog fra Kunstnerforbundet 1918.

8 Brev fra EW til BG datert 22.4. 1910. 


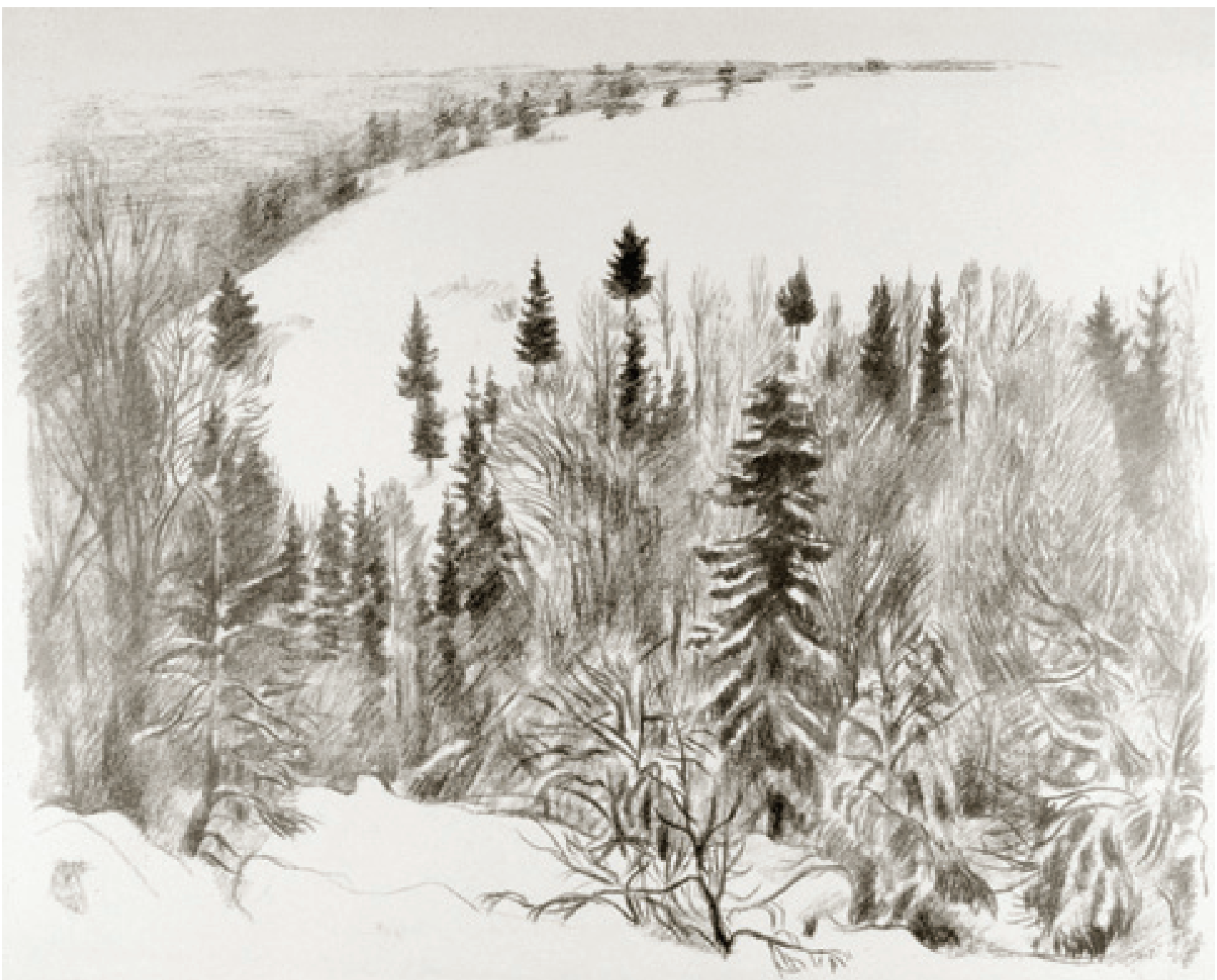

Vinter oppi bakken, 1928. Litografi. (Kat.nr. 188)

Det er interessant å notere seg hvilke motiver Werenskiold hadde valgt ut for det amerikanske markedet. Et troll, en pike med lyst hår og et vinterlig landskap, motiver som illustrerer en tradisjonell og utbredt forestilling om det nordiske. På nyåret 1934 deltok Werenskiold med fire litografier i Riga, i januar 1937 sto København på plakaten. Den siste store utenlands-utstillingen han var representert ved, ser ut til å ha vært Verdensutstillingen i Paris 1937. Til denne mønstringen sendte han syv litografier. ${ }^{9}$ Ifølge den håndskrevne oversikten var dette En prat (1919), Tømmerlasset (1928), Gutten som

9 Denne utstillingen står ikke oppført i Norsk Kunstnerleksikon 1986, som har en fyldig oversikt over Werenskiolds utstillinger i inn- og utland. Opplysningen er hentet fra Werenskiolds håndskrevne notater og grafikkoversikt. 


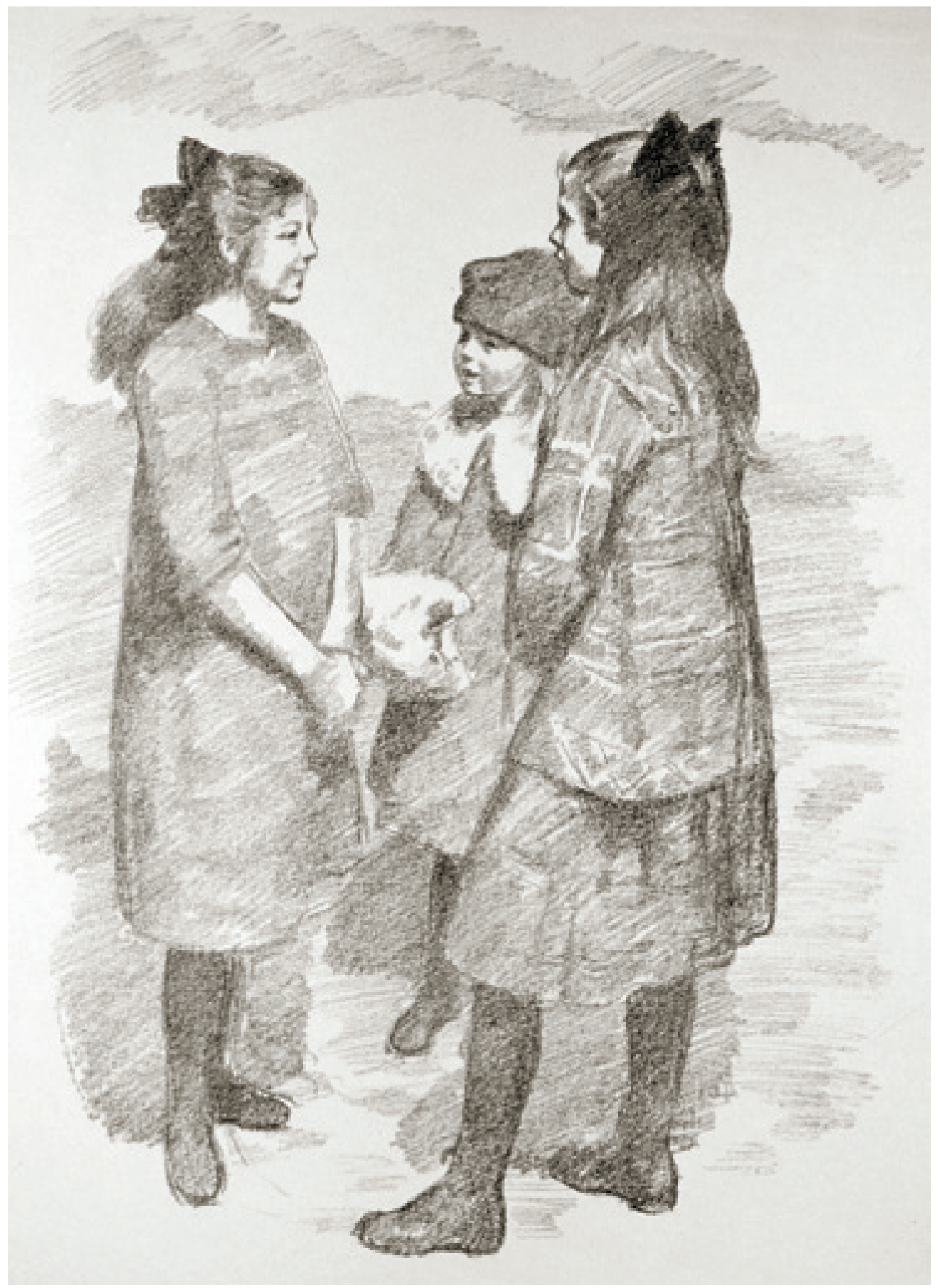

En prat, 1919. Sinkografi. (Kat.nr. 146) 
hugger hodene av trollet I (1929), Glomma fra Kongsvinger festning (1929), Den hvite dame (1929), Wergeland på Veslebrunen, I (1934) og Falketind III (1935).

26. februar 1938 åpnet Erik Werenskiolds siste utstilling i Kunstnerforbundet, bare ni måneder før han døde. Utstillingen var omfattende og viste malerier, akvareller, tegninger og et større antall litografier. Maleriet Lensekara (1938) ble innkjøpt av Nasjonalgalleriet, et kjøp som må ha gitt et tilsvarende litografert motiv ekstra oppmerksomhet. Litografiet Lensekara II ble solgt i så mange som ti eksemplarer. Med en liberal holdning til trykkemetoder fikk Werenskiold produsert motivet som litografisk maskintrykk i november 1937 og som tradisjonelt litografi på nyåret 1938. Lensekara må for øvrig være det motivet som flest nordmenn i ettertid har stiftet bekjentskap med, siden motivet ble gjengitt på den fjerde utgaven av hundrekroneseddelen som var i omløp fra 1949 til 1962. 



\section{Demokratiserende aspekter i oppbyggingen av grafikkmiljøet i Norge}

Det var ikke bare det å være kunstner som opptok Erik Werenskiold. Han la også ned et betydelig arbeid for kunstens kår, for kunstens stilling i samfunnet, for allmennhetens forståelse av bildekunst og for samfunnets ansvar for kulturlivet i vid forstand. Hans sterke engasjement på den hjemlige kunstarenaen har gitt ham karakteristikken «alle norske kunstneres våkne samvittighet». ${ }^{1}$ I framveksten av et forsiktig spirende grafikkmiljø i Norge var hans innsats og initiativ av stor betydning. Han var en av pådriverne i etableringen av et fagmiljø for grafikere i Norge. Her var det blant annet nødvendig å sørge for kunstnernes utdannings- og arbeidsforhold. Det var også viktig å berede grunnen for et marked gjennom allmenn kjennskap til grafikk, og etter hvert etablere organisasjoner som kunne ivareta de norske grafikernes interesser. Med opprettelsen av Radérklassen ble det mulig å få en håndverksmessig skolering i radering og litografi, og med etableringen av grafikkorganisasjoner kunne kunstnerfellesskapet styrkes. Etableringen av Kobberstikk- og håndtegningsamlingen var vesentlig for kunst- og kulturlivet.

\section{Kobberstikk- og håndtegningsamlingen}

Mønsteret for det som skulle skje på grafikkfronten i Norge på slutten av 1800- og begynnelsen av 1900-tallet, finnes igjen i den europeiske aktiviteten på området. I forhold til de kontinentale grafikkmiljøene på denne tiden, som hadde lagt bak seg et langt løp, hadde det norske bare så vidt kommet til startblokkene. Forbilder til etterfølgelse ute i Europa inspirerte til entusiastisk nybrottsarbeid og gjorde etableringen av nødvendige institusjoner enklere. På flere av kunstens områder var Norge på denne tiden ennå bare et nybyggersamfunn. Kobberstikk- og håndtegningsamlingen ble etablert i Christiania i 1877. Gjennom den ble publikum gitt en ny og bedre mulighet til å studere ulike grafiske uttrykk.

I Sidsel Helliesens bok Norsk grafikk gjennom 100 år hevdes det, som riktig er, at det er vanskelig å danne seg noe bilde av hva denne opprettelsen kan ha hatt for betydning for det gryende norske grafikklivet. ${ }^{2}$ Men det er fristende å anta at den må ha gitt en form for positiv effekt. I hovedstadens oversiktlige kunstmiljø, hvor kommunikasjonslinjene var relativt fa, inngikk den som en av flere små milepæler i etableringen av grafikkrelaterte tiltak som skulle komme de neste årene. Kobberstikk- og

Johannesen, «Omkring Erik Werenskiold og hans bilder i de bergenske samlinger», 17.

Helliesen, Norsk grafikk gjennom 100 år, 124. 
håndtegningsamlingen kan betegnes som en virksomhet med markedsforberedende og informative intensjoner, samtidig som den kan knyttes til et dannelsesaspekt i forhold til et kulturinteressert publikum. Selv om den norske offentlige samlingen av grafiske blad var liten, uansett hvilken annen internasjonal samling man kan velge å sammenligne den med, var intensjonen at den skulle «... kunde skaffe os Adgang til at blive bekjendt med de beste Reproduktioner af alle Tiders største Kunstverker, som vi ikke havde Anledning til at se i Original, og som derhoskunde forklare os Kunstverkenes Tilblivelsesproces gjennem tilgjængelige Originaltegninger, Skizzer og Studier [...]».3 På stiftelsesmøtet den 24. februar 1877 ble statuttene utarbeidet. $\$ 1$ slo fast at Kobberstikk- og haandtegningssamlingen skulle inneholde «alle Slags Arbeider af den mangfoldiggjørende Kunst samt Haandtegninger». ${ }^{4}$ Etableringen av Kobberstikk- og håndtegningsamlingen hadde også en pedagogisk intensjon. Den ville videreføre kunnskap om både eldre og nyere grafiske teknikker. Til enhver tid skulle deler av samlingen stilles ut, slik at publikum kunne eksponeres for kjente mesteres mest betydningsfulle arbeider. ${ }^{5}$ Med erfaring som konservator fra Gravyr- och Handteckningsamlingen i Stockholm, hadde kunsthistorieprofessor Lorentz Dietrichson, grafikksamler Diderik Maria Aall og flere på rekordtid fått samlingen etablert og klar til åpning den 7. oktober 1877.

Utgangspunktet for samlingen var gaver gitt av private grafikkentusiaster og samlere i Norge. De første årene holdt den til i «paviljongen i Paléets have», og var tilgjengelig tre ganger i uken. ${ }^{6}$ Etter å ha eksistert som selvstendig institusjon i seks år, ble Kobberstikk- og håndtegningsamlingen overdratt til Nasjonalgalleriet i 1883. En av konsekvensene ved denne overdragelsen var at samlingen kunne flytte inn i bedre og mer sentrale lokaler i Skulpturmuseets nyoppførte bygg på Tullinløkka. Dette lettet tilgangen for de grafikkinteresserte og, som en konsekvens, økte publikumsbesøket. Fra et tilbaketrukket liv i «bakgården» kom samlingen opp og fram i en mer offentlig sammenheng, og ble oppsøkt i en helt annen utstrekning enn tidligere. ${ }^{7}$

For dem som interesserte seg for grafikk før forrige århundreskifte, hørte det til den europeiske dannelsestradisjonen å omgi seg med enkelte grafiske trykk, gjerne reproduksjonstrykk, som veggdekorasjon. Dannelses- og opplysningstanken hadde en betydningsfull alliert i den gamle grafikken. Nils Messels artikkel i utstillingskatalogen for Kobberstikksamlingens jubileum i 2002 har fått undertittelen «Utdrag fra en dannelseshistorie», en benevnelse som ikke bare kan oppfattes rent praktisk, men også kan ses ut fra en pedagogisk holdning til grafikk som bildemedium. Det er denne pedagogiske ideen og den demokratiserende holdningen som Werenskiold også kan ses som en eksponent for.

\section{Radérklassen}

I 1899 startet kartograf Johan Nordhagen som lærer ved den nyopprettede Radérklassen ved Den kgl. norske Kunst- og Haandværksskolen i Christiania. Før opprettelsen av klassen hadde Erik Werenskiold og andre engasjert seg for at Norge skulle få flest mulig egne utdanningsinstitusjoner. I denne forbindelsen var det av stor betydning å gi

3 Prof. Lorentz Dietrichson i tiltredelsesforelesning ved Universitetet i Oslo 24. februar 1876, i Messel, «Kobberstikk- og håndtegningsamlingen i Christiania. Utdrag fra en dannelseshistorie», 9.

Helliesen, Norsk grafikk gjennom 100 år, Kobberstikk- og håndtegningsamlingens forhandlingsprotokoll 1877-1895 (1-2), 28-29 og note 32. Ibid.

6 I dag utgjør deler av Paléhaven Christian Frederiks plass sydøst for Jernbanetorget i sentrum av Oslo. Christian Ancher (1711-1765) var opprinnelig eier av Paléet og anla hagen med lindeallé i 1760-årene.

7 Willoch, Nasjonalgalleriet gjennem hundre år, 99. 
grafikkinteresserte kunstnere mulighet til å få opplæring her hjemme. Prosessen begynte med en henvendelse til Kirkedepartementet i 1897, hvor kunsthistoriker Lorentz Dietrichson, kunstnerne Eilif Peterssen, Hans Gude og Erik Werenskiold, folkelivsgransker Moltke Moe og naturvitenskapsmannen Fridtjof Nansen søkte om midler til en årlig lønn for Nordhagen. Forutsetningen var at han skulle studere «radering og lithografi i udlandet for derefter at overtage en lærerpost ved den Kgl. Kunst- og håndværksskole i disse fag». ${ }^{8}$ For å påvirke Stortinget foran behandlingen av saken om opprettelsen av klassen, hadde pressgruppen valgt å argumentere for viktigheten av prosjektet ved å understreke litografiets og raderingens betydning som reproduserende kunst. Gruppen framholdt at bildekunsten skulle gjøres tilgjengelig for allmennheten i landet, og understreket «verdien av økt spredningen av billedekunst gjennom gjengivelse». ${ }^{9}$ I dette skinner folkeopplysningsideen og en demokratisk holdning igjennom, og understreker bildemediets helt spesielle pedagogiske kvalitet. Mer enn det skrevne ordet, kan det visuelle uttrykket på en enkel måte formidle kunnskap eller budskap. Vårt første møte med ord og begreper er ikke en nedskrevet fortelling, men en bildebok med enkle, gjenkjennelige motiver. W.J.T. Mitchell gir situasjonen karakteristikken «one of the earliest pedagogical rituals in [...] elementary education». ${ }^{10}$ Ved å framheve reproduksjonsgrafikken som et bildemedium med bred appell, kan denne formen for grafikk karakteriseres som spydspissen i etableringen av et marked for den friere grafikken som vokste fram i løpet av de neste tiårene.

Johan Nordhagen var en solid håndverker på grafikkens område, en kompetanse som passet godt med undervisningens hensikt og formålet med Radérklassens oppgaver. I forhold til en friere grafisk utfoldelse hadde den reproduserende formen et mer nøyaktig språk, og bare i begrenset grad rom for personlige preg. Rent formalt inntar den en slags mellomstilling mellom den frie kunstgrafikken og det tidlige, tradisjonelle kobber- og stålstikket. Frigjøringen fra den historiske og mer rigide strekføringen i kobber- og stålstikket var en konsekvens av etsningsrenessansen i Europa.

Blant det første årets elever var Einar Sandberg (1876-1947), som før han begynte i Radérklassen, hadde fått tegneundervisning av Erik Werenskiold. Andre tidlige elever var Hans Ødegaard (1876-1949), Ivar Lund (1871-1904), Albert Næss (1873-1947) og Hans Holm (1878-1946). Mange av de arbeidene som ble utført hadde et solid håndverksmessig skolepreg med motiver som virket tiltalende på et bredt publikum. ${ }^{11}$

De som $\mathrm{i}$ andre halvdel av 1800-tallet ivret for en gjenoppliving av det grafiske kunstuttrykket, hevdet at grafikken sto i særstilling som den eneste kunstform som virkelig kunne bringe kunstneren og kunsten i et direkte og levende forhold til folket. ${ }^{12}$ Radérklassen og miljøet rundt den hadde stor betydning for framveksten av et nasjonalt grafikkmiljø. Men den mer kreative og kunstneriske utfoldelsen på området ble først og fremst ivaretatt av personer som sto utenfor Nordhagenskolen. ${ }^{13}$ Til disse må Erik Werenskiold regnes. ${ }^{14}$

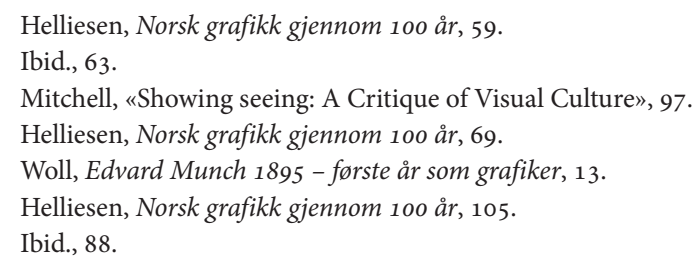




\section{Grafikkforeninger}

Organisasjonssamfunnet ble et nytt begrep i Norge i løpet av det 19. århundre. ${ }^{15}$ Befolkningen ble bevisst det virkningsfulle i mer offisielt organiserte former for samhandling. De nye organisasjonene, til forskjell fra eldre former for formaliserte fellesskap, bygde på frivillighetsprinsippet. De nye interesseorganisasjonene ble på denne tiden sterke aktører i et mer åpent og «folkeopplyst» samfunn. Tidligere tiders organisasjonsløse samfunn var i ferd med å gå over i historien, og organisasjoner i seg selv var et betegnende uttrykk for samfunnsendringene.

Den samfunnsengasjerte Erik Werenskiold og andre visste å benytte seg av denne nye muligheten, og det finnes utallige eksempler på organisasjoner og foreninger som ble stiftet av personer i hans kulturpolitiske omgangskrets. Organiseringen av det norske grafikkmiljøet er et talende eksempel på hvordan denne nye impulsen førte til at en interessegruppe ryddet seg plass på samfunnsarenaen.

Som vi har sett både i forbindelse med etableringen av Kobberstikk- og håndtegningsamlingen og senere når det skulle argumenteres for etablering av utdanningsmuligheter, var det reproduksjonsgrafikken som ble trukket fram som betydningsfull. Men det er viktig å merke seg at under opprettelsen og organiseringen av utenlandske grafikkforeninger som fungerte som forbilder for de norske, var framhevingen av grafikk som reproduserende kunstform ikke like sterkt til stede. For flere av de europeiske interesseorganisasjonene var det tvert imot av betydning å understreke grafikkens særlige stilling som en subjektiv og selvstendig kunstart. I Europa hadde de avsluttet denne fasen med vekt på reproduksjonsgrafikk for flere generasjoner siden. Her til lands måtte det forsømte tas igjen i løpet av kortest mulig tid, og argumentasjonen bar preg av at et viktig avsnitt og et betydningsfullt stadium med fokus på det håndverksmessige ikke kunne eller burde forseres.

I 1908 ble Norsk Forening for Grafisk Kunst (NFfGK) dannet. Foreningens formål var, ifølge paragraf 1 i lovene, «at udbrede Kjendskabtil degrafiskeKunster og fremmederes Udvikling, særligved Udbredelse blandt Medlemmerneafgode Originalarbeider af norske Kunstnere». ${ }^{16}$ Foreningens uttalte hensikt var altså å rette fokus mot originalgrafikken, og «man var fuldt paa det rene med at grafik ikke i første række [lenger var å betrakte som] en reproduksjonskunst». ${ }^{17}$ Etter noen år med fokus på håndverksmessige og reproduserende kvaliteter, lå nå veien åpen for at kunstgrafikken skulle kunne appellere til publikum.

I løpet av årene som hadde gått fra Kobberstikk- og håndtegningsamlingen ble etablert og fram til den første grafikkforeningen var et faktum, hadde reproduksjonsgrafikken utspilt sin rolle. ${ }^{18}$ De grafiske foreningenes formålsparagrafer framhevet sterkt den kunstneriske muligheten som lå i grafikken, og et av foreningenes viktigste formål var å framheve originalgrafikk som kunstnerisk uttrykksform. I Frankrike hadde La Société des Aquafortistes markedsført etsekunsten som den fremste formen for originalgrafikk. En av foreningens stiftere, Théophile Gautier, skrev: "I disse tider når fotografiet forleder den ukyndige gjennom den mekaniske sannheten i sine produkter, må det i kunsten oppstå en bevegelse for det frie innfallet og en malerisk fantasi. Behovet for å reagere mot positivismen i denne speilmekanikk har fătt

15 Nerbøvik, Norsk historie 1870-1905. Frå jordbrukssamfunn mot organisasjonssamfunn, 127.

16 «Love for Norsk Forening for Grafisk Kunst», vedtatt på den konstituerende generalforsamlingen, 20. mai 1908. NFfGK - arkivsaker, Nasjonalmuseets/ Nasjonalgalleriets dokumentasjonsarkiv, gjengitt i Helliesen, «100 år i grafikkens tjeneste: Norsk Forening for Grafisk Kunst 1908-2008», 5 og note 11.

17 Olaf Willums og Eli Ingebretsen, Om grafisk kunst, 72.

18 Helliesen, Norsk grafikk gjennom 100 år, 55 . 
flere enn én maler til å ta etter etsenålen. [...] Dersom dere tilfeldigvis finner noen av de blad som inngår i denne samling altfor vilde og voldsomme, tenk da på at all reaksjon først går i ekstrem retning, og at La Société des Aquafortistes er dannet nettopp for å bekjempe fotografiet, litografiet, akvatintetsningen og den slags gravyr der de kryssende linjene har en prikk i midten. Sagt på en annen måte: det regelmessige automatiske arbeidet, uten inspirasjon og tømt for alle kunstneriske idéer. Her har kunstnerne villet kommunisere direkte med sitt publikum og bærer selv risikoen." ${ }^{19}$

Den franske grafikkforeningen hadde til hensikt å gi ut årlige mapper med originalgrafikk til betalende medlemmer gjennom en abonnementsordning, og ble stiftet så tidlig som i 1862. Men allerede fem år senere måtte foreningen legge ned på grunn av sviktende interesse fra allmennheten. Abonnementsmodellen ble også praktisert i NFfGK.

I Tyskland ble Berlin Verein für Originalradierungen dannet i 1886. Foreningen fikk følge av flere lignende interessegrupper bl.a. i München (1892) og Karlsruhe (1894). I Tyskland gikk veien via reproduksjonsgrafikken, før autoriteter på området valgte å fokusere på original-etsningens fortreffelighet. Men også de tyske kunstnerne slet med å skaffe seg et publikum og et marked for originalgrafikken. ${ }^{20}$

Når grafikkens fortropper i Norge skulle vinne gehør for sine framstøt, var det en veloverveid strategi å framheve reproduksjonsgrafikkens kvaliteter. Med en heller lav oppslutning i de første årene, besluttet også NFfGK å inkludere denne mer allment kjente og aksepterte produksjonsformen ved at formålsparagrafen ble omarbeidet i 1911. ${ }^{21}$ NFfGKs arbeid med å utbre kjennskap til det trykte bildet må anses som et vellykket prosjekt, og i 1919 hadde medlemstallet økt til hele 586. Medlemsmassen var jevnt fordelt mellom innbyggere i og utenfor byene..$^{22}$

Det er verdt å merke seg at NFfGK hadde et romslig forhold til hva de definerte inn under kategorien «gode grafiske arbeider», siden den i statuttene lot det omfatte både originalgrafikk og reproduksjonsgrafikk. I andre land som var tidligere ute med å etablere lignende organisasjoner, og som hadde vært forbilder for organiseringen i Norge, gikk det som nevnt et skille mellom disse uttrykksformene. Den organiserte grafikkbevegelsen i Norge skiller seg dermed fra det som ute i Europa utgjorde «originalgrafikkbevegelsen». De europeiske miljøenes poengtering av grafikk som original og autentisk kunst var et resultat av den tidligere omtalte etsningsrenessansen, som utelukkende ønsket å legge vekten på grafikkens mulighet til kunstnerisk frihet. Selv om det dreier seg om en mangfoldiggjørende kunstform, signaliserer denne distinksjonen en mindre inkluderende holdning til reproduksjonsgrafikken enn det som var tilfellet hos oss.

I de første vanskelige etableringsårene for grafikere i Norge var NFfGK av stor betydning for kunstnerne som kom med i de årlige mappene som ble utgitt. Ved at hele opplag ble innkjøpt, fikk de et kjærkomment tilskudd til inntekten, og de fikk publisert sine arbeider. Erik Werenskiold var med i tre mapper i løpet av sitt liv, i 1910, 1918 og 1935, med ett verk hvert av årene. ${ }^{23}$ I 1939, året etter at han døde, var han også representert med ett arbeid. ${ }^{24}$ I 1945 inneholdt mappen tre streketsninger, alle laget av Erik Werenskiold. Årsmapper med kun én kunstner representert har vært en sjeldenhet i foreningens historie. I 1946-mappen

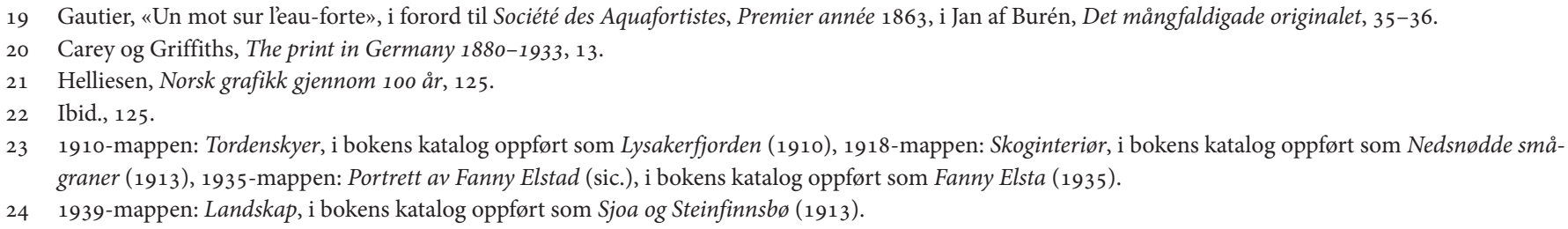


finner vi to verk av Werenskiold. At Norsk Forening for Grafisk Kunst valgte å fokusere på Werenskiolds grafikk rett etter 2. verdenskrig, var ganske sikkert ingen tilfeldighet. Trykkene som inngikk i 1945-mappen, var Troll (1913), Skog i sne (1912) og Dansende småpiker (1920). ${ }^{25}$ I 1946-mappen ble Trollet og prinsessene (1911) og Landskap (1913) tatt med. ${ }^{26}$

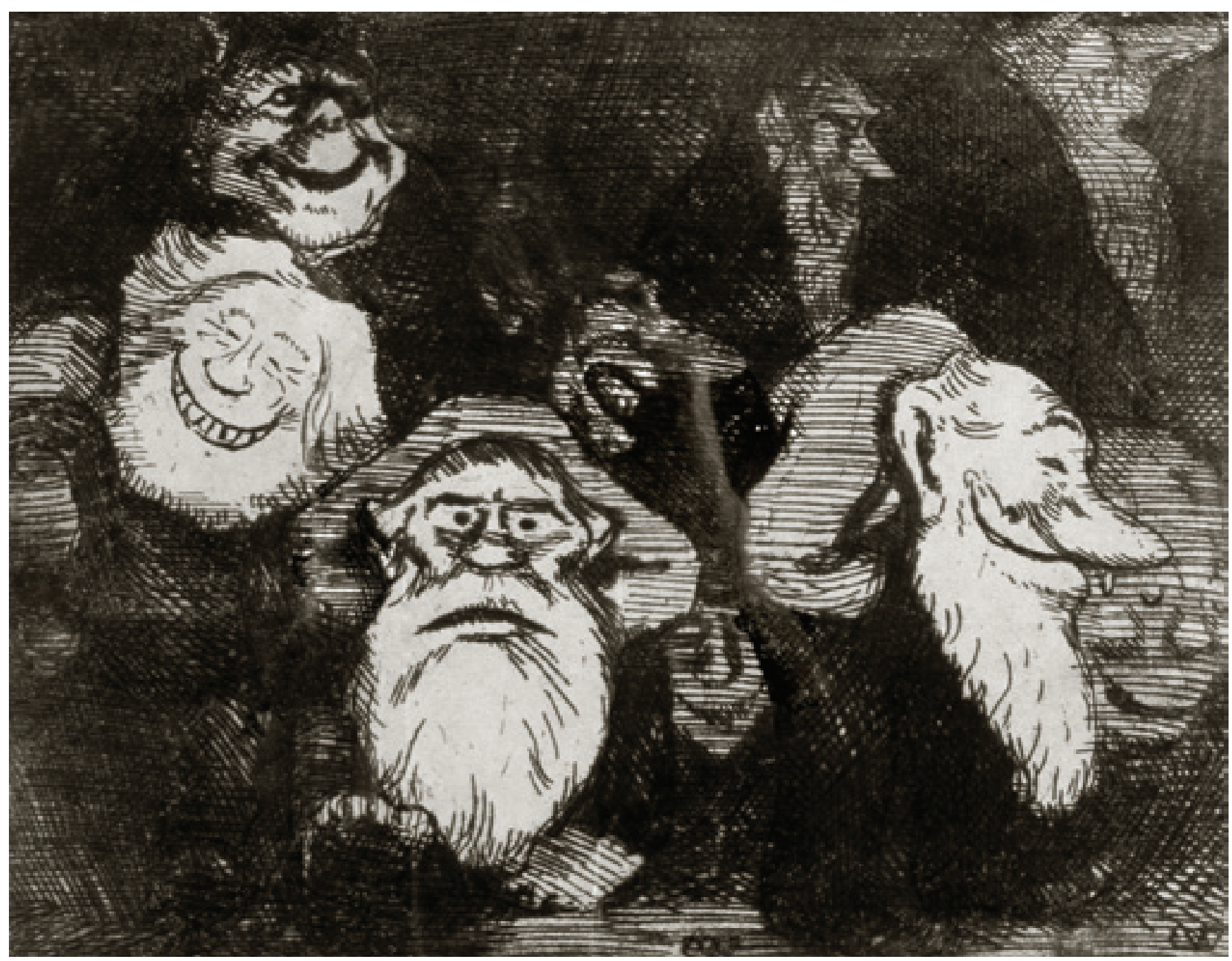

Trollpakk I, 1913. Streketsning. (Kat.nr. 36)

25 1945-mappen: Troll, i bokens katalog oppført som Trollpakk I (1913), Skog i sne er oppført som Gran og furu med snø på (1912), Dansende småpiker er oppført som Vi er på ball (1920).

26 1946-mappen: Trollet og prinsessene, i bokens katalog oppført som Trollkjerringa og de tre prinsessene (1911), Landskap (Sjoa og Steinfinnsbø, 1913) er det samme motivet som ble utgitt i 1939-mappen. 


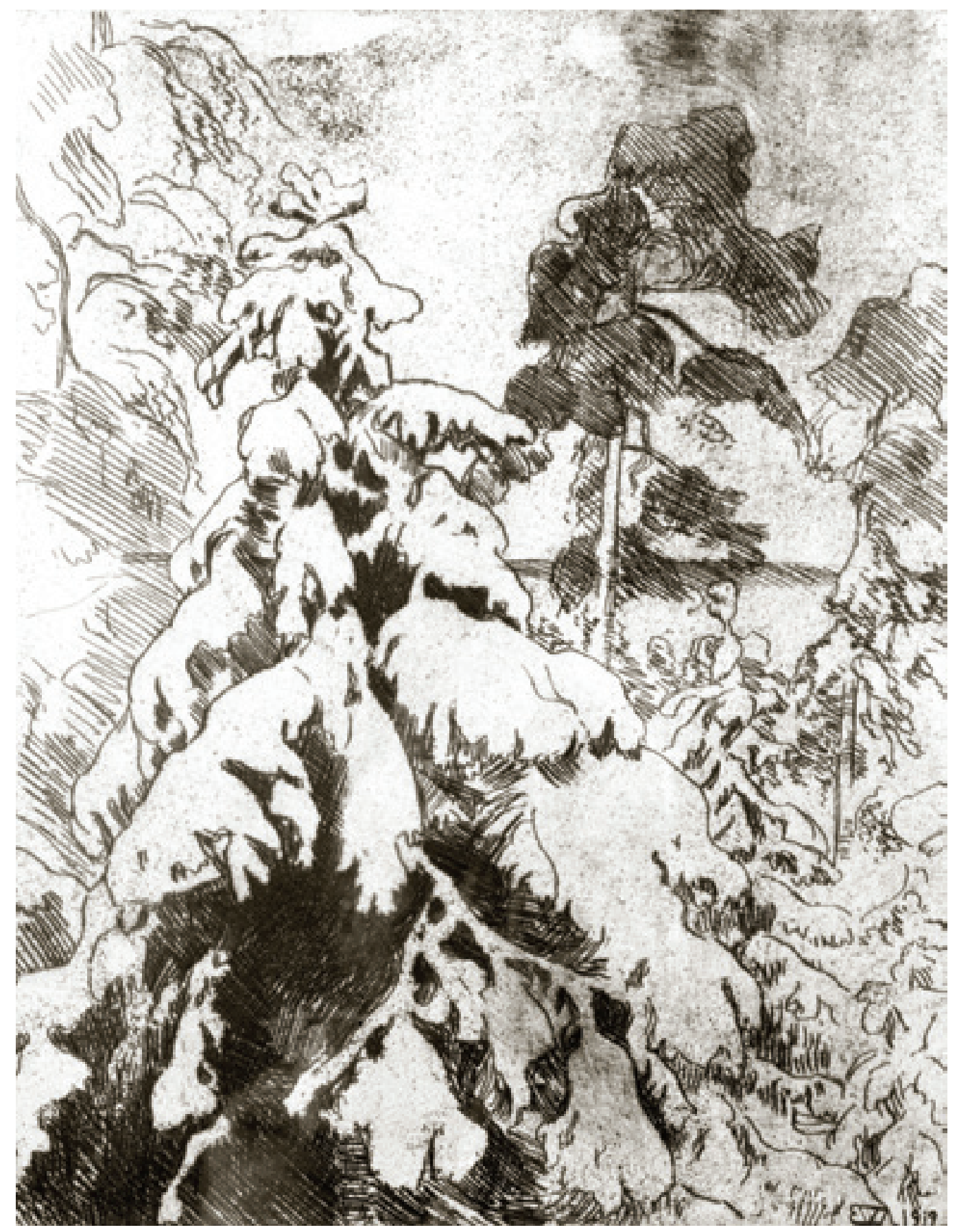

Gran og furu med snø på, 1912. Streketsning. (Kat.nr. 32) 


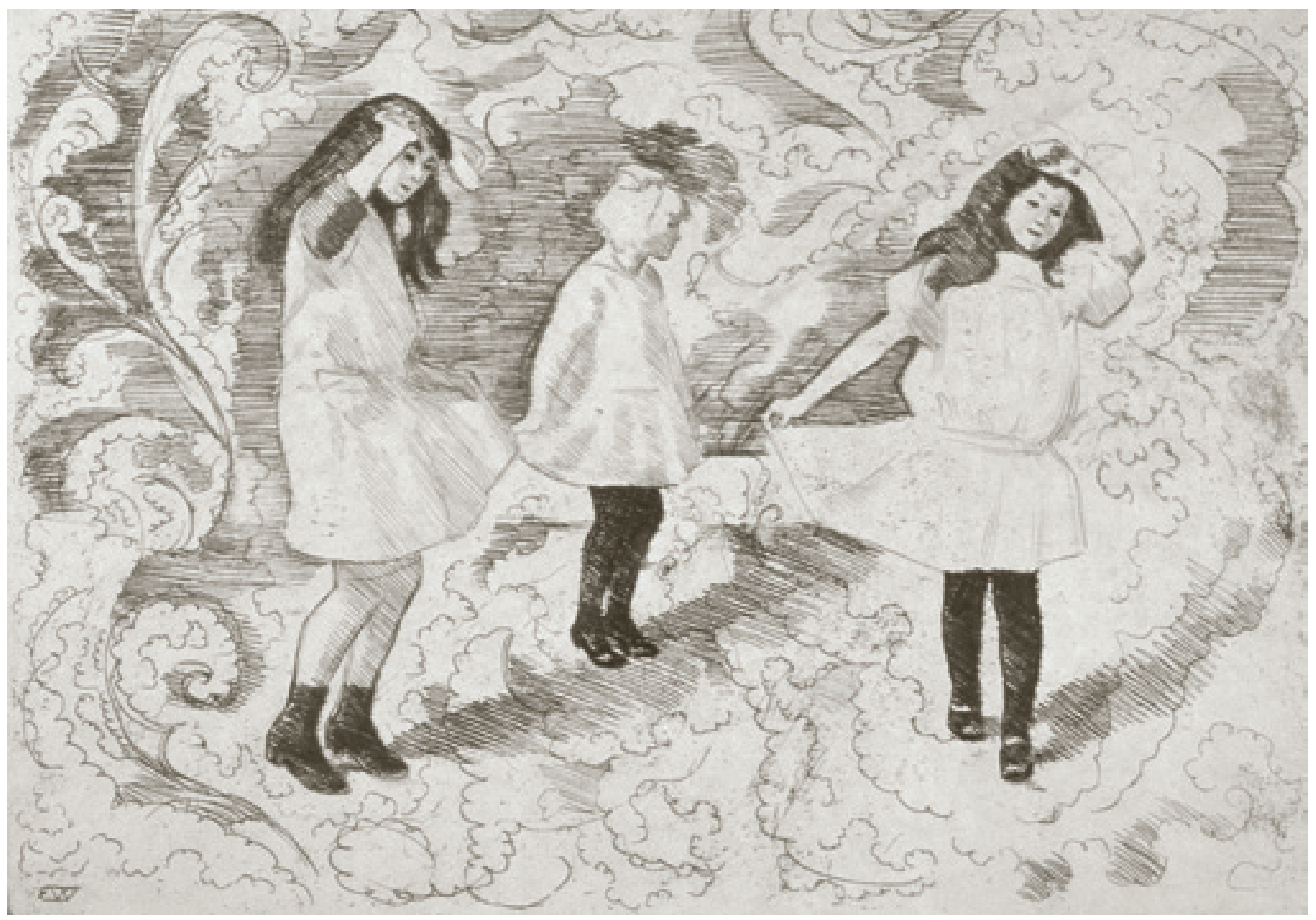

Vi er på ball, 1920. Streketsning. (Kat.nr. 131)

Alle motivene bygde opp under folks positive forhold til norsk natur og kultur. Nok en gang kunne Werenskiolds naturalisme være en understreking av at hans kunst kunne fungere som et visuelt gledesbudskap. Norge var igjen et fritt, demokratisk land.

I 1919 hadde nok en interesseorganisasjon blitt dannet. Til foreningen Norske Grafikere var Erik Werenskiold blant dem som inviterte til stiftelsesmøtet. Etter ti år som grafiker inngikk han i miljøet som ifølge $\$ 1$ i vedtektene «på beste måte [skulle] vareta norske grafiske kunstneres felles interesse». ${ }^{27}$ Foreningens opprettelse førte til en intensivering i arbeidet blant annet med å bedre trykkemulighetene og å skaffe egnede utstillingslokaler. 
Erik Werenskiolds motivasjon for å gi seg i kast med radering og litografi henger nøye sammen med hans forutsetninger. Hans tegneferdigheter og erfaringene fra illustrasjonsoppdragene gjorde det nærliggende å velge teknikker hvor han kunne videreføre kompetansen. Men for Werenskiolds del kan vi ut fra det som har kommet fram om hans engasjement på grafikkfronten før han selv ble utøver av kunsten, hevde at han nærmet seg grafikken via flere kanaler. Beslutningen om å radere var ikke en plutselig innskytelse, men en bestemmelse som modnet i ham over tid. Enten han var premissleverandør, aktør eller observatør i den mer organisatoriske fasen, må hans engasjement ha virket inn på beslutningen om endelig å begynne med radering og noen år senere med litografi. 



\section{Bibliografi}

Asbjørnsen, Peter Christen. Norske Folke- og Huldreeventyr i Udvalg. Kjøbenhavn: Gyldendalske Boghandels Forlag, 1879.

Asbjørnsen, Peter Christen. Eventyrbog for Børn, I-III. Kjøbenhavn: Gyldendalske Boghandels Forlag, 1883, $1884,1887$.

Aslaksby, Trond E. «Christian Krohg og fotografiet: Noen observasjoner og refleksjoner.» I Vibeke Wallann Hansen et al. (red.),

Christian Krohg: Bilder som griper. Oslo: Nasjonalmuseet for kunst, arkitektur og design, 2012.

Aubert, Andreas. Norsk kultur og norsk kunst. Kristiania: Steenske Forlag, 1917.

Bartsch, Adam von. Catalogue raisonné de toutes les Estampes Qui forment l'oeuvre de Rembrandt et ceux de ses principaux imitateurs.

Wien: A. Blumauer, 1797. https://ia800304.us.archive.org/32/items/raisonnedetoutes00gers/raisonnedetoutes00gers.pdf

Bartsch, Adam von. Le peintre graveur. Vol. 1. Wien: J.V. Degen, 1803. https://ia801704.us.archive.org/5/items/ gri_000133125001964234/gri_000133125001964234.pdf

Berg, Knut, Nils Messel og Marit Lange. «Maleriet 1870-1914». I Norges kunsthistorie: Nasjonal vekst. Bind 5, redigert av Knut Berg et al. Oslo: Gyldendal Norsk Forlag A/S, 1981.

Bergson, Henri. Matter and Memory. Autorisert oversettelse, N.M. Paul og W.S. Palmer, 1908-versjon, 5. utg. Reprint London: George Allen \& Unwin Ltd., 2012.

Bjerke, Øivind Storm. Tun og vassdrag: Telemarks typologier. Oslo: Kunstnernes hus, 1998.

Burén, Jan af. Det mångfaldigade originalet. Stockholm: Carlssons Bokförlag, 1992.

Christensen, Olav. «En nasjonal identitet tar form: Etniske og nasjonale kulturelle avgrensninger.» I Jakten på det norske, redigert av Øystein Sørensen, 51-73. Oslo: Gyldendal Akademisk, 1998.

Connor, Celeste. Democratic Visions: Art and Theory of the Stieglitz Circle, 1924-1934. London: University of California Press, 2001.

Denis, Maurice. «Cézanne - I». I The Burlington Magazine for Connoisseurs, redigert av Roger Fry og Maurice Denis, Vol. 16, No. 82, 1910: 207-209+212-215+219. http://www.jstor.org/stable/858022

Eggum, Arne. Munch og fotografi. Oslo: Gyldendal, 1987.

Erlandsen, Roger. Pas nu paa: Nu tar jeg fra Hullet! Om fotografiens første hundre år i Norge - 1829-1940. Våle: Forlaget Inter-View i samarbeid med Norges Fotografforbund, 2000.

Fremmerlid, Anny. «Erik Werenskiolds grafikk og Paul Cézanne.» I Kunst og kultur, nr. 3, 2012: 165-171.

Fry, Roger. Cézanne: A Study of His Development. 1927. New York: The Noonday Press, 1958.

Goksøyr, Matti. «Idretten og det norske: aktivitet som identitet.» I Jakten på det norske, redigert av Øystein Sørensen, 159-175.

Oslo: Gyldendal Akademisk, 2001.

Hamilton, George Heard. «Cézanne, Bergson and the Image of Time.» I College Art Journal. Vol. 16, No. 1, 1956: 2-12. http://www. jstor.org/stable/772842

Haug, Kristian. «Erik Werenskiold.» I Aftenposten (aftenutgaven), 5.10.1918.

Helliesen, Sidsel. Norsk grafikk gjennom 100 år. Oslo: H. Aschehoug \& Co, 2000.

Hinterdingen, Erik, Ger Luijten og Martin Royalton-Kisch. Rembrandt the Printmaker. Amsterdam: The British Museum Press og Rijksmuseum Amsterdam, 2000. 
Hodne, Bjarne. Norsk nasjonalkultur: En kulturpolitisk oversikt. 2. utg. Oslo: Universitetsforlaget, 2002.

Hodne, Ørnulf. «Sagn og eventyr som nasjonalkultur.» I Jakten på det norske: Perspektiver på utviklingen av en norsk nasjonal identitet på 1800-tallet, redigert av Øystein Sørensen, 125-140. Oslo: Gyldendal Akademisk, 2001.

Ingebretsen, Eli. «Om norsk grafisk kunst.» I Om grafisk kunst, redigert av Olaf Willums og Eli Ingebretsen, 47-88. Oslo: Gyldendal Norsk Forlag, 1928.

Ivins jr., William Mills. Print and Visual Communication. Cambridge, Massachusetts: The MIT Press, 1969.

Johannesen, Ole Rønning. «Omkring Erik Werenskiold og hans bilder i de bergenske samlinger.» Katalog til Erik Werenskiolds minnesutstilling. Bergen Billedgalleri, februar-mars 1955.

Johannesson, Lena. «Fenomenet Zorn - världs- och verklighetserövran.» I Zorn i svart och vitt: Anders Zorn som etsare, tecknare och fotograf, redigert av Birgitta Sandstrøm, 111-141. Mora: Zornsamlignarna, 2002.

Jussim, Estelle. Visual Communication and Graphic Arts. New York: R.R. Bowker Company, 1974.

Malmanger, Magne. «Norsk kunstdebatt ved modernismens terskel.» I Kunst og Kulturs Serie. Nr. 1 1985: 2-45.

Messel, Nils. «Da fjellet ble oppdaget.» I Oppdagelsen av fiellet, redigert av Nils Messel og Marianne Yvenes, 7-87. Oslo: Nasjonalmuseet for kunst, arkitektur og design, 2008.

Mitchell, William John Thomas. «Showing seeing: A Critique of Visual Culture.» I The Visual Culture Reader, 2. ed., redigert av Nicholas Mirzoeff, London: Routledge, Taylor \& Francis Group, 2002.

Myhre, Jan Eivind. Asker og Borums historie: Bcerum 1840-1980. Oslo: Universitetsforlaget, 1982.

Nerbøvik, Jostein. Norsk historie 1870-1905: Frå jordbrukssamfunn mot organisasjonssamfunn. Ny utg. 2. oppl. Oslo: Det Norske Samlaget, 1990.

Nielssen, Finn. «Erik Werenskiold i Kunstnerforbundet.» I Tidens Tegn 9.3. 1938.

Nochlin, Linda. Realism. 2. utg. Harmondsworth: Penguin Books, 1990.

Rolfsen, Johan Nordahl. Loesebog for folkeskolen, 1-5. Kristiania: Jacob Dybwads Forlag, 1892-1895.

Scharf, Aaron. Art and Photography. New York: Pinguin Books, 1974.

Schiff, Richard. «Seeing Cézanne.» I Critical Inquiry, Vol. 4, No. 4. 1978: 769-808. http://www.jstor.org/stable/1342954

Schiff, Richard. Cézanne and the End of Impressionism: A Study of the Theory, Technique, and Critical Evaluation of Modern Art. Chicago og London: The University of Chicago Press, 1984.

Skedsmo, Tone. «Kunst for alle: Kunst i alt» Tradisjon og fornyelse: Norge rundt århundreskiftet, redigert av Glenny Alfsen, Ellen Lerberg og Nils Messel, 7-25. Oslo: Nasjonalgalleriet, 1995.

Sturlason, Snorre. Kongesagaer. Ca. 1220. Kristiania: J.M. Stenersens Forlag, 1899.

Weisberg, Gabriel P. Beyond Impressionism: The Naturalist Impuls. New York: Harry N. Abrams Publishers, 1992.

Werenskiold, Erik. Håndskrevne notater og grafikkoversikt. «Raderinger og Litografier». Lysaker, påbegynt 1909.

Werenskiold, Erik. Brev fra Erik Werenskiold til Bernt Grønvold. Brevsamling 98. Nasjonalbibliotekets håndskriftsamling.

Werenskiold, Erik. «Rembrandt og Cézanne.» Opprinnelig i Kunstbladet, 1908 under samme tittel. I Kunst. Kamp. Kultur: Gjennem 40 aar i tekst og billeder, Kristiania 1917, redigert av Inge Debes og Anders Krogvig, 96-98. Kristiania: Alb. Cammermeyers Forlag, 1917.

Werenskiold, Erik. «Impressionisterne.» Opprinnelig i Nyt tidsskrift, 1882 under samme tittel. I Kunst. Kamp. Kultur: Gjennem 40 aar $i$ tekst og billeder, redigert av Inge Debes og Anders Krogvig, 63-67. Kristiania: Alb. Cammermeyers Forlag, 1917.

Werenskiold, Erik. «Skjønhetssans.» Opprinnelig i Forceldre og børn 1902 under samme tittel. I Kunst. Kamp. Kultur: Gjennem 40 aar $i$ tekst og billeder, redigert av Inge Debes og Anders Krogvig, 89-91. Kristiania: Alb. Cammermeyers Forlag, 1917. 
Werenskiold, Marit. «Erik Werenskiold og Paul Cézanne.» I Erik Werenskiold og hans krets: Utfordringen fra Cézanne, redigert av Marit Werenskiold og Øivind Storm Bjerke, 9-29. Lillehammer: Lillehammer kunstmuseum, 2010.

Willoch, Sigurd. Nasjonalgalleriet gjennem 100 år. Oslo: Gyldendal Norsk Forlag A/S, 1937.

Woll, Gerd. Edvard Munch 1895: Første år som grafiker. Oslo: Munchmuseet, 1995.

Østby, Leif. Erik Werenskiold. 2. utg. Oslo: Grøndahl og Dreyers Forlag AS, 1993.

Brev fra Erik Werenskiold til Bernt Grønvold. Brevsamling 98. Nasjonalbibliotekets håndskriftsamling. 



\section{Katalog}

Til tross for at Erik Werenskiold hadde en relativt stor produksjon av raderinger og litografier, er Erik Werenskiold ikke særlig kjent som grafiker. I løpet av 30 år, fra 1908 til 1938, laget han 85 raderinger og 162 litografier. Grafikk kan ses som en utvidelse av hans svart-hvitt-kunst, en slags videreføring av tegningen som var et av hans veletablerte og høyt verdsatte kunstuttrykk. Noen eksperimenterende holdning til mediene kommer ikke fram i de 247 arbeidene; verdien i grafikken ligger først og fremst i motivene. Ser vi dem samlet, bidrar de til bildet av Norge på begynnelsen av 1900-tallet.

De aller fleste verkstitlene i denne oeuvre-katalogen er Erik Werenskiolds egne, funnet $i$ hans håndskrevne grafikkoversikt. Når det gjelder nøyaktigheten og systematikken i dateringene, opplyser Werenskiold at hans oversikt har en del feil og mangler. Han understreker at feildatering gjelder spesielt for litografiene som ble laget før 1929. Werenskiold skriver: «Først nu, november 1929, begynner jeg å nummerere litografiene, men i de første rekker er det en del feil, fordi jeg har git bort til barna og kanske solgt enkelte unummererte. $\aleph^{1}$ Dette stemmer godt med erfaringene som er gjort i løpet av arbeidet med katalogen. Det er også funnet både raderinger og litografier som ikke er oppført i Werenskiolds notater. Disse er forsøkt plassert i kronologien ut fra opplysninger om lignende motiver eller ut fra begivenheter de kan knyttes til.

Werenskiolds opusnummerering er funnet enten i hans notater eller som påskrift på trykkene. Katalogen til «Minneutstilling, sort og hvitt», 6.-28. Januar 1940 i Kunstnernes Hus, har vært en supplerende kilde og en viktig kryssreferanse i denne sammenhengen.

\section{Trykkplater}

Erik Werenskiold benyttet tre typer trykkplater til raderingene: rene kobberplater, forstålede kobberplater og i ett tilfelle nikkelbelagt kobber. De forstålede kobberplatene tåler større opplag enn de av rent kobber. I 1910 hadde Werenskiold kommet til at trykk fra kobberplater var "vakrere" og hadde en annen kvalitet enn trykk fra forstålede plater. Han ville heretter arbeide på rent kobber. ${ }^{2}$ Men erkjennelsen førte ikke til en konsekvent bruk av kobberplater. Flere trykk etter 1910 er fra stålbelagte plater, blant annet portrettet av Hans E. Kinck (1914) og de fleste av portrettene av familien Heiberg fra 1915 - 1916. Raderingen fra den nikkelbelagte platen Lyse sommer er laget i 1914.

Werenskiolds håndskrevne notater og grafikkoversikt, upaginert.

Brev fra Erik Werenskiold (EW) til Bernt Grønvold (BG) 18.10.1910. 
Werenskiold gjorde bruk av to forskjellige størrelser på dyptrykkplatene. Mest brukt er størrelsen ca. $320 \mathrm{x} 250 \mathrm{~mm}$. Målene på de ferdige verkene varierer med noen få millimeter. Den andre størrelsen fikk han ved å halvere "standardplaten” til 160 x $250 \mathrm{~mm}$.

Siden Werenskiold stort sett laget dyptrykk i form av etsninger, var det nødvendig å sette platene inn med etsegrunn. De første platene ble ikke preparert av Werenskiold selv. Disse var han ikke fornøyd med. Grunderingen var for hard og falt av i flak. Han ville helst gjøre denne delen av arbeidsprosessen selv og søkte råd hos andre, kombinerte rådene med egne erfaringer og utviklet på den måten sine ferdigheter på området.

Litografiene ble for det meste tegnet på litografisk overføringspapir, før de ble overført til kalksteinen av en litograf. I noen tilfeller trykte Werenskiold sine litografier fra sinkplater (sinkografi), slik som for eksempel Tone og Bebe (1922).

\section{Papir}

Papiret som motivet trykkes på, er et viktig element i alle former for grafikk. Det har avgjørende betydning for kvaliteten på det ferdige trykket. Bruk av ulike papirsorter til trykking av grafikk er alminnelig. Bruk av forskjellig papirkvaliteter var viktig også for Erik Werenskiold. Selv om et lite grafikkmiljø i Kristiania hadde vært i framvekst en tid, gir han i sine notater inntrykk av at det var få papirforhandlere i byen tidlig på 1900-tallet. Det første papiret Werenskiold trykte sine raderinger på, fikk han hos Johan Nordhagen på Den kgl. norske Kunst- og Haandværksskole. Siden bestilte han papir både til seg selv og til Nordhagen fra R. Wagner i Berlin. Bernt Grønvold sørget for at han fikk tilsendt papirprøver fra forhandleren. ${ }^{3}$ Det mest brukte papiret i Werenskiolds raderinger er japanpapir.

Papir til litografier ser det ut til at Werenskiold blant annet bestilte fra USA. På en av de første sidene i den håndskrevne grafikkoversikten er den norskfødte maleren Jonas Lie (1880-1940) oppført som kontaktmann. Litografiene ble trykket på japanpapir av forskjellig tykkelse, på “alminnelig” papir og på bøttepapir. Werenskiold likte spesielt godt japanpapir, og beskriver det som "is-aktig, tykt, hvitt, deilig" eller som "gul-aktig og bløtt”. I 1929 trykte han litografier på papir fra Alvøen. I ett tilfelle er det funnet et litografi, Wergeland på Veslebrunen (1934), trykt på kapok, et mykt trykkark som er ca. $5 \mathrm{~mm}$ tykt og oppfører seg som vanlig bomull. Fridtjof Nansen, Werenskiolds nabo og nære venn, er den som skal ha startet med å trykke litografier på dette materialet her hjemme.

\section{Trykking}

Det var ikke innlysende for Erik Werenskiold hvor han skulle henvende seg for å få etsningene sine trykt. De trykkemulighetene han først og fremst så for seg, var å finne i Berlin. I oktober 1908 skrev han til Grønvold: "til våren [vil jeg reise] til Berlin for at trykke raderinger; da skal man helst være tilstede. Det er jo sørgelig at her ikke er en trykker; det tar for meget tid at gjøre det selv." 5 Dette kan virke noe overraskende, siden Werenskiold selv hadde vært med på opprettelsen av Radérklassen, og vært med på ansettelsen av Johan Nordhagen. Men det er altså ikke en selvfølge for ham å spørre Nordhagen om hjelp til dette.

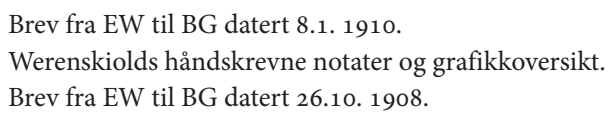


Isteden utsetter han i første omgang trykkingen til han har radert et antall plater slik at han kan få trykt flere samtidig, for å spare tid, siden han må helt til Berlin for å få det gjort. I mars 1909 uttrykker han det slik: "Det er besværlig med trykning; men den tid er vel ikke fjern da vi får trykkeri her.”' ${ }^{3}$ De aller første raderingene blir, til tross for Berlin-planene, allikevel trykt med assistanse fra Nordhagen på Radérklassens presse, men det ser ut til at han litt senere sendte syv plater til trykking i Berlin.7

Det nye trykkeriet med dyptrykkpresse som Werenskiold håpet skulle bli opprettet, ble en realitet i 1910. Scheel i Kristiania fikk i gang en presse, og en ung lærling på 21 år fra München hadde kommet for å bistå ham. Lærlingens ferdigheter strakk seg i starten ikke lenger enn til det rent håndverksmessige. Men igjen er Nordhagen til hjelp, og med assistanse fra ham en kort periode, bedrer det ytterligere på lærlingens kunnskaper. Det er dessuten av betydning for både lærling og kunstner at Werenskiold selv benytter muligheten til å være til stede under trykkingen. På denne måten kunne Werenskiold vurdere platenes virkning på papiret, og etter hvert som både trykker og kunstner opparbeidet seg mer erfaring hvert på sitt felt, gikk arbeidet lettere. ${ }^{8}$

I oktober 1913 leverte Werenskiold ti plater til et trykkeri i 289 Rue St. Jaques i Paris. Hvilke ti plater det dreier seg om, vites ikke. Opplysningen står anført i Werenskiolds håndskrevne notater, hvor det også framgår at hele forsøket med et nytt trykkeri i Paris var mislykket. Det ser ut til at han i det store og hele benyttet Scheels presse i Kristiania til raderingene.

Ved å gå over til den litografiske teknikken ble Werenskiold enda mer avhengig av trykkeriets dyktige håndverkere. Som nevnt benyttet han gjerne overføringsteknikk, hvor tegningen utføres på spesialpreparert papir for så å overføres til steinen. Overføringen og trykkingen ble gjort av Anton Peder Nielsen, som var en av byens beste litografer. ${ }^{9}$ Ved et par anledninger ble litografier trykt som maskintrykk hos Grøndahl \& Søn og hos Thon i Staffelsgate $2 .^{10}$

\section{Reproduksjonsgrafikk og autotypier}

Det finnes eksempler på at Werenskiolds malerier ble laget som etsninger og litografier i reproduksjonsgrafisk gjengivelse, utført av elever i Radérklassen. Werenskiolds pennetegninger, kulltegninger og raderinger finnes også reprodusert som autotypier. ${ }^{11}$ Disse kan lett forveksles med Werenskiolds originalgrafikk.

Gjengivelse av de aktuelle autotypiene tas derfor med som en presisering i katalogens siste del.

Oljemaleriet En bondebegravelse (1883-1885) ble gjengitt som streketsning av Johan Nordhagen i 1893-1894. Dette var det første store verket han utførte som radering. Her viser Nordhagen sin evne til nitid gjengivelse av detaljer. Hans oversettelse av farger til svart-hvite modelleringer og gjengivelser av lys og skygge gir det grafiske verket et uttrykk som

\footnotetext{
Brev fra EW til BG datert 15.3. 1909.

Katalognummer 4, 5, 6, 7, 8, 9, 10.

Brev fra EW til BG datert 4.7. 1910.

Anton Peder Nielsen (Kildeborg) var dansk, utdannet i Tyskland og slo seg ned i Norge i 1903. Han etablerte sitt eget trykkeri, Litografia, på Bekkelaget i 1922. Nielsen Kildeborg hjalp for øvrig fra ca. 1910 Edvard Munch med trykking av både litografier og tresnitt. I Gerd Woll, Edvard Munch: The Complete Graphic Works, 20.

10 Henholdsvis Wergeland på Veslebrunen II (1934) og Lensekara I (1937).

11 Snl.no, s.v. autotypi. Autotypi eller rasterklisjé er en fotokjemisk gjengivelse. Det opprinnelige motivet blir fotografert gjennom et raster før det overføres til en trykkplate som etses. Oppfinnelsen er fra 1881 og kreditert tyske Georg Meisenbach. Ifølge Griffiths, i Prints and Printmaking, 123, ble autotypien utviklet på 1870-tallet, og ute i Europa kom den i bruk i kommersielle sammenhenger rundt 1880. Metoden var den mest brukte for bokillustrasjoner helt fram til 1960-tallet.
} 
harmonerer med maleriets. Raderingen "har blitt stående som et av hans hovedverk". ${ }^{12}$ Den raderte utgaven av En bondebegravelse tiltrakk seg raskt oppmerksomhet. At Nordhagens verk har gått inn i den kulturelle bevisstheten, kommer til uttrykk over tyve år etter at det ble laget, da det ble trukket fram i en gratulasjonsnotis i forbindelse med hans 60-årsdag. ${ }^{13}$

Et maleri av Erik Werenskiolds far, kaptein Fredrik Werenskiold (1800-1887), ble mangfoldiggjort som litografi i 1901. Werenskiold skrev: "Mit portræt af min far litograferes udmærket af en ung fyr." ${ }^{14}$ "Fyren" var en av Johan Nordhagens elever, den 24-årige Ole Engh (1877-1947), og litografiet er en svært god gjengivelse av oljemaleriet av kapteinen fra 1878. Litografiet har tittelen Min far. Da maleriet ble laget, hadde den 78 år gamle kaptein Werenskiold nylig avsluttet 60 års tjeneste i det militære. Ole Engh var ifølge skolens protokoll oppført som kveldselev fra 1899 til 1903. Engh deltok med grafikk på Høstutstillingen i 1903, 1904 og 1905. Det ser ikke ut til at Ole Engh har hatt behov for å utvikle seg videre som maler eller grafiker. Det oppgis at hans kunstneriske virke var begrenset til interessen for reproduksjonsgrafikk. Ole Engh hadde isteden sitt virke knyttet til Norges Geografiske Oppmåling, der han ble ansatt allerede i 1892, og han ble der hele sitt yrkesaktive liv. Tegneskolens undervisning inngikk som en del av fagopplæringen for karttegnere, og ferdighet i de grafiske teknikker var en forutsetning for hans arbeid som kartograf. ${ }^{15}$

Werenskiolds maleri Professor Amund Helland (1885) ble i 1901 radert av Radérklassens elev Einar Sandberg. Sandberg hadde fått undervisning av Werenskiold på slutten av 1890-tallet, før han oppsøkte Nordhagens klasse. ${ }^{16}$ Agronom Einar Sandberg vekslet mellom å være dag- og aften-elev i de fire årene han var innskrevet, mellom 1899 og 1903. Han mottok undervisning både i litografi og radering.

Andre malerier av Werenskiold som ble gjengitt som ble reprodusert som etsninger, var Elling Bjørsets (1878-1938) radering Dagfin (1899) etter oljemaleriet med samme tittel. Hans Holm (1878-1946) litograferte Erika Nissen etter maleriet Pianistinnen Erika Nissen (1892). For Holm ble reproduksjonslitografiet en spesialitet. Han ble innskrevet i Radérklassen våren $1903 .{ }^{17}$

Som vi ser, var det Nordhagen-skolens elever som sto for reproduksjonen av Erik Werenskiolds oljemalerier. Radérklassens arbeider kom på denne måten Werenskiold til gode ved at noen av hans malerier kunne spres og gjøres tilgjengelig for et større publikum. Samtidig fikk Radérklassens elever tilgang på gode forlegg.

I arbeidet med registreringen av Werenskiolds grafikk har noen av motivene dukket opp som autotypier (fotokjemiske gjengivelser). Det gjelder raderingene Høyfjell (1908/1909), Nedsnødde smågraner (1913) og litografiet Tone og Bebe (1922). Ved første øyekast kan Høyfjell og Nedsnødde smågraner virke noe gråere enn originalen, men autotypiene er allikevel av svært god kvalitet. ${ }^{18}$ Den dempede tonen kommer tydeligst fram i de mørkeste delene av bildeflaten. De opprinnelige

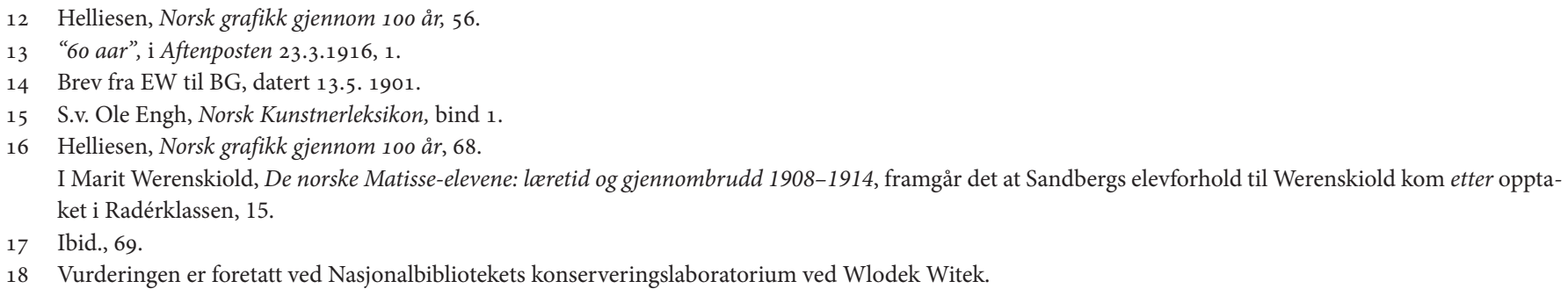


etsningene har dermed et større spenn i skalaen mellom svart og høylys enn det autotypien har. Gjennom mikroskop ses bildeflaten som et regelmessig mønster av en mengde større og mindre svarte punkter.

Motivene har preging fra en plate i papiret. Om dette skyldes omrisset av en trykkplate, eller om pregingen er et blindtrykk laget etter trykking av motivet, er vanskelig å fastslå. Preget i papiret har en grunnere karakter enn på de opprinnelige trykkene. Platepreget ligger godt utenfor motivet på autotypiene. På de originale raderingene er platemål og motivmål identiske. De to nevnte autotypiene er noe forminsket i forhold til originalene. ${ }^{19}$

Litografiet Tone og Bebe har ikke den samme rasterstrukturen som de reproduserte etsningene. Hvilken reproduksjonsform som er brukt i dette tilfellet, er ikke like enkelt å fastslå, og kan bare gis den generelle betegnelsen "fotomekanisk overføring.". forhold til originalen. De tre reproduserte motivene har Erik Werenskiolds påskrift og signatur utenfor bildeflaten.

Eksperimentering med fotomekaniske overføringer var et utbredt fenomen på Werenskiolds tid, og et uoversiktlig landskap å orientere seg i for ettertiden. Selv om metodene ble brukt i kommersielle sammenhenger, kan vi anta at enkelttrykk produsert på denne måten også hadde sin verdi. Motivene kan ha vært brukt som "gave-vedlegg" i julehefter eller andre typer publikasjoner ment for allmennheten.

Originalgrafikk, reproduksjonsgrafikk, bokillustrasjoner og fotomekaniske gjengivelser viser at Erik Werenskiold visste å ta i bruk både de historiske teknikkene og de mer moderne som lå i tiden. I 1937 utga Gyldendal Forlag 24 kull- og pennetegninger samlet i en mappe. Dreyers Litografiske Anstalt i Stavanger sto for selve trykkingen. Ifølge opplysninger fra Nasjonalbibliotekets konserveringslaboratorium er også denne mappen laget som autotypier i særdeles god kvalitet. Ved å studere trykkene i mikroskop kan en se at enkelte områder er bearbeidet for hånd, sannsynligvis for å viske ut gråtoner som ville gitt en "skitten" virkning i det ferdige trykket. Det har i noen tilfeller vist seg at kunstmarkedet forveksler mappens kulltegningstrykk med Werenskiolds litografier. Mappen inneholder en eventyrillustrasjon og illustrasjoner fra Familien på Gilje og Snorres kongesagaer. Mappen inneholder også en interessant sammenstilling av portretter: Fridtjof Nansen, Bjørnstjerne Bjørnson og Edvard Grieg, Ernst Sars, Henrik Ibsen og Nini Roll Anker, men også Lars Fiskerhytta.

\section{Forklaringer til katalogen}

Titler: Så langt som det har vært mulig er det Werenskiolds egne titler som er brukt slik de finnes i hans håndskrevne notater, som påskrift på enkelte verk eller i utstillingskataloger. De motivene som ikke forekommer i disse kildene er gitt en beskrivende tittel av forfatteren.

Datering: Alle verk er gitt et årstall, selv om flere er usikre. Dette er markert med et spørsmålstegn. Usikkerheten gjelder særlig noen av de som er dater etter 1930.

\footnotetext{
19 Autotypien Høyfjell har motivmål 230 x 300 og platepreg 240 x 310. Den tilsvarende etsningen har motivmål og platemål 245 x 318 . Autotypien Nedsnødde smågraner har motivmål 305 x 235 og platepreg 314 X 243, mens den tilsvarende etsningen måler $320 \times 244$.
} 
Mål: Alle mål er oppgitt i millimeter og i høyde x bredde. For etsningene gjelder platemål. For litografiene gjelder motivmål. I identiske motiver kan det forekomme variasjoner i målene. Målene må derfor betraktes som veiledende.

Opplag: Erik Werenskiold brukte serienummerering (nr. 1., nr. 2. osv. ) eller ingen nummerering på sin grafikk. Dette betyr at det ikke er mulig å fastsette hvor mange eksemplarer som finnes av hvert motiv. Her er det bare mulig med en generell kommentar ut fra det som kommer fram i kunstnerens notater: Etsningene forekommer som oftest i få eller svært få eksemplarer, mens litografiene jevnt over er trykket i et større antall.

Opus: Erik Werenskiolds nummerering. Raderinger og litografier er nummerert i to separate lister, og har derfor i en rekke tilfeller identiske opusnummer.

\section{Forkortelser}

EW Erik Werenskiold

BG Bernt Grønvold

NFfGK Norsk Forening for Grafisk Kunst 


\section{Første forsøk}

1904

EW: Uten opusnummer

\section{Streketsning}

Plate: $168 \times 195 \mathrm{~mm}$

Motiv: $105 \times 171 \mathrm{~mm}$

Ingen signatur eller datering $\mathrm{i}$ platen.

Motivet er fra Bagn i Valdres.

En tegning datert 1893 med

samme motiv eies av

Nasjonalmuseet for kunst

arkitektur og design, Oslo. III. til

Jonas Lie, Familien på Gilje. (Inv.nr.

NG.K\&H.B.05003)

\section{3 \\ 1908-1909}

EW: Opus o

Streketsning

$235 \times 299 \mathrm{~mm}$

Signert i platen n.t.h.

EW (speilvendt i trykket).

Motivet er tegnet i platen i 1908 og trykt i 1909

Motivet finnes i tre eller fire

eksemplarer ifølge Werenskiolds

håndskrevne notater. Platen

ødelagt.

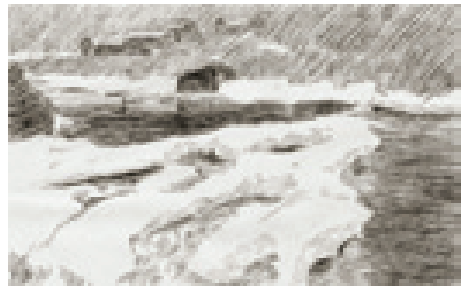
Båter under Lysakerbrua 1908-1909

EW: Uten opusnummer

\section{Streketsning}

$245 \times 323 \mathrm{~mm}$

Ingen signatur eller datering $\mathrm{i}$ platen.

Motivet er tegnet i platen i 1908 og trykt i 1909.

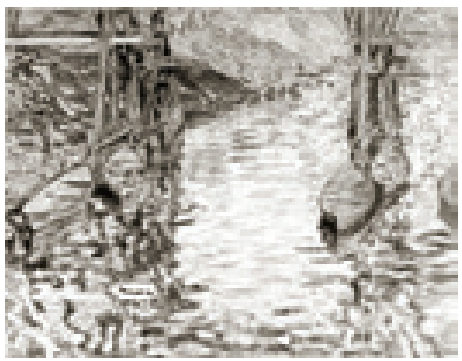

4

\section{Høyfjell}

1908-1909

EW: Opus 1

Streketsning

$245 \times 318 \mathrm{~mm}$

Tilstand I: Signert og datert platen n.t.v.: EW 1809 [sic.]

Tilstand II: Signert og datert i platen n.t.v.: EW 1908.

Motivet er tegnet i platen i 1908 og trykt i 1909.

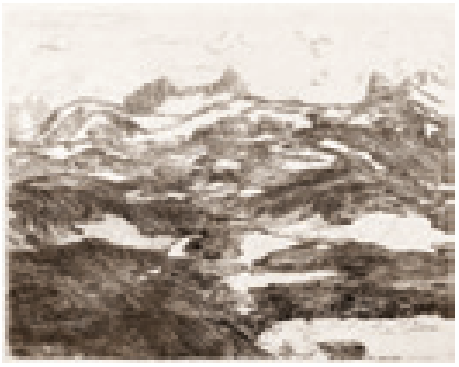


5

Den engelske flåte

1908-1909

EW: Opus 7

Streketsning

$233 \times 298 \mathrm{~mm}$

Signert og datert i platen n.t.v.: EW 1809 [sic.]

Motivet er tegnet i platen i 1908 og trykt i 1909.

Den engelske flåte var på

Norges-besøk i juni 1908. I

Dagbladet 19. juni 1908: "18500

engelskmenn er i dag seilt inn til

vår by. Man kan fylle en middels

norsk by med dem. Det [er] uten

sammenligning det største

flåtebesøk vi noensinne har hatt.

Skipenes antall er 53 og av

offiserer er de 900."

Motivet er tegnet idet skipene

passerer utenfor Lysaker

Oslofjorden.

\section{Lysakerbrua, vinter \\ 1908-1909}

EW: Opus 3

Streketsning

$248 \times 315 \mathrm{~mm}$

Signert i platen n.t.v.: EW

Motivet er tegnet i platen i 1908 og trykt i 1909.

Platen ble ødelagt ved et uhell.

Utstilt på Scessesionen i Berlin

1909.

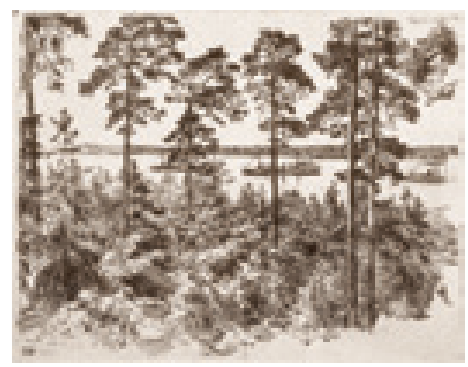

Bjørnstjerne Bjørnson i slåbrok

1908-1909

EW: Opus 2

Streketsning

$297 \times 240$

Signert og datert i platen n.t.v: EW 1908

Motivet er tegnet i platen i 1908 og trykt i 1909.

Etsningen ble laget før Bjørnsons nest siste reise til Paris. Han er avbildet i sitt vanlige arbeidsantrekk: "Slåbroken" var hans skrivejakke.
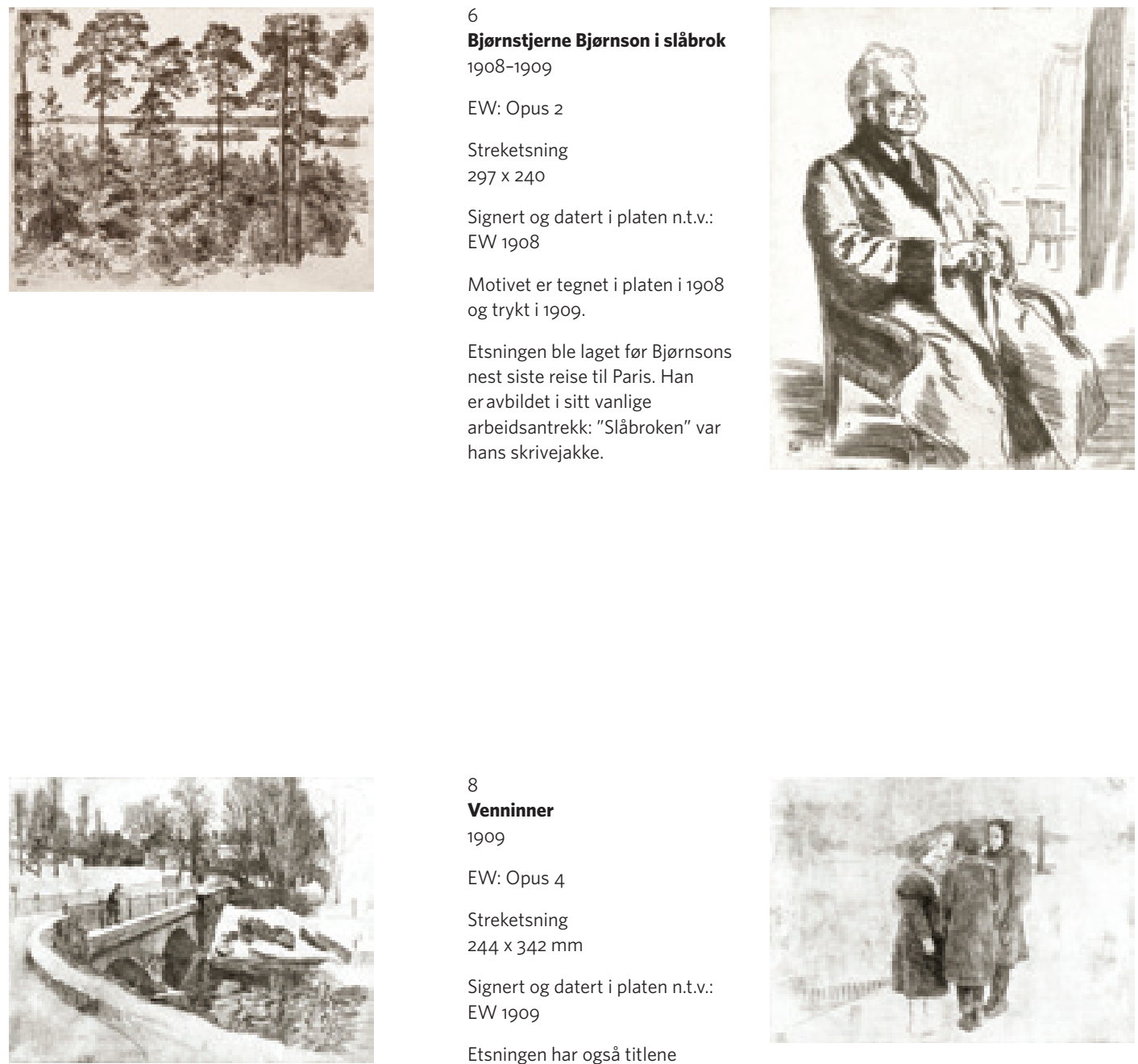

Venninner

1909

EW: Opus 4

Streketsning

$244 \times 342 \mathrm{~mm}$

Signert og datert i platen n.t.v.: EW 1909

Etsningen har også titlene

Småjenter og Krøplingen og hennes venninner.

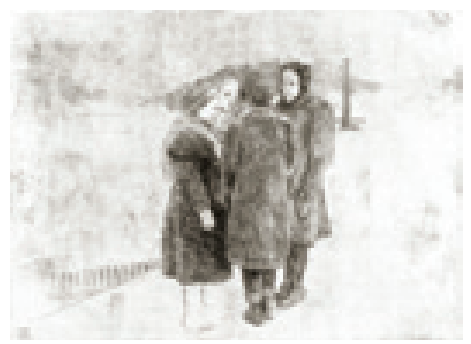


9

Nansens hus, Polhøgda

1909

EW: Opus 5

Streketsning

$246 \times 312 \mathrm{~mm}$

Signert og datert i platen n.t.h.: EW 1909

Fridtjof Nansen flyttet inn på

"Polhøgda" i 1900. Nansen hadde selv ideen til huset. Det er tegnet av arkitekt Hjalmar Welhaven, Eva Nansens fetter. Welhaven hadde også tegnet Nansens første bolig "Godthåb" som lå nede ved Oslofjorden. "Polhøgda" fikk sitt navn under et innvielseskarneval, og refererer til

Nansens "polhøyde" som han nådde under nordpolferden 1893-1896.

Utstilt på Scessesionen i Berlin 1909

\section{Kullsjau}

1909

EW: Opus 8

Streketsning

$248 \times 320 \mathrm{~mm}$

Signert og datert i platen n.t.v.: EW 1909

Utstilt på Scessesionen i Berlin 1909

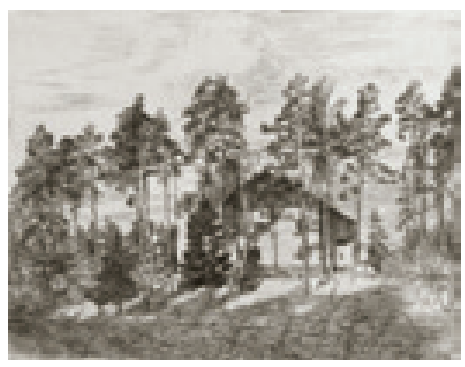

10

1909

EW: Opus 6

Streketsning

$237 \times 297 \mathrm{~mm}$

Signert og datert i platen n.t.h. EW 1909

Utstilt på Scessesionen i Berlin 1909.

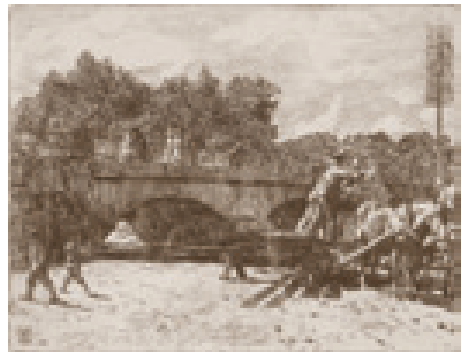

Løpende troll

1909

EW: Opus 10

Streketsning

$245 \times 320 \mathrm{~mm}$

Signert og datert i platen n.t.v.: EW 1909

Raderingen finnes ifølge Werenskiolds håndskrevne grafikkoversikt, i kun tre eksemplarer. Ett ble 6. juni 1909 sendt til M. Lehrs ved Kgl.

Kupferstichkabinet

Druckengallerie i Dresden, ett fikk mesenen Bernt Grønvold i Berlin, og ett beholdt Werenskiold selv. Platen ble ødelagt.
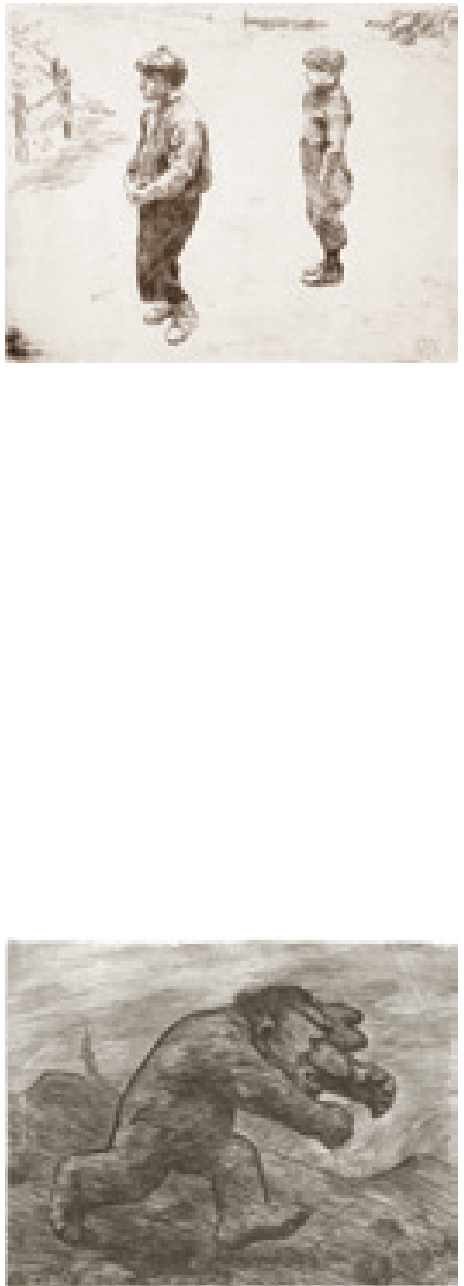

(c) Kupferstich-Kabinett, Staatliche Kunstsammlungen Dresden, 


\section{Da rant solen}

1909

EW: Opus 11

Streketsning

Etsningen har også tittelen

Døende troll notert i Werenskiolds

håndskrevne grafikkoversikt.

Finnes i svært få eksemplarer.

Platen er ødelagt.

15

Tre prinsesser

1910

EW: Opus 12

Streketsning

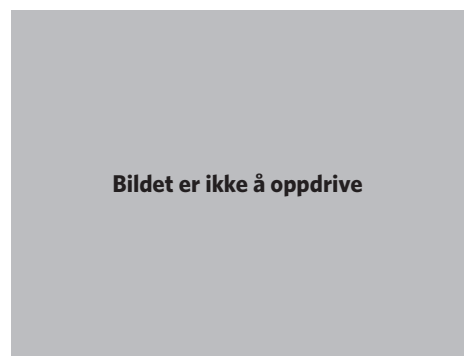

Bjørnsons begravelse

1910

EW: Opus 9

Streketsning

$244 \times 319 \mathrm{~mm}$

Signert og datert i platen n.t.v.

EW 1910 1/5

Bjørnstjerne Bjørnson døde i Paris 26. april 1910. Hans kiste ble ført hjem fra Paris med tog til

København, og videre med

panserskipet "Norge" som ankom

Kristiania 1. mai. Skipet hadde

splittflagget på halv stang, og den

flaggsmykkede kisten som var

plassert på akterdekket hadde

militær æresvakt. Skipet ble møtt med kongelig salutt (21 skudd) fra

Akershus festning. Bjørnson ble

gravlagt på Vår Frelsers gravlund

3. mai.

\section{Lysakerfjorden}

1910

EW: Opus 13

Streketsning

$247 \times 320 \mathrm{~mm}$

Signert i palten o.t.v.: EW

Platen ble trykt i to omganger:

først i 1910, og siden 7 trykk i 1914.

10 av trykkene i 1910 er fra

forstålet kobberplate. I NFfGK

årsmappe 1910. Tittel Tordenskyer.
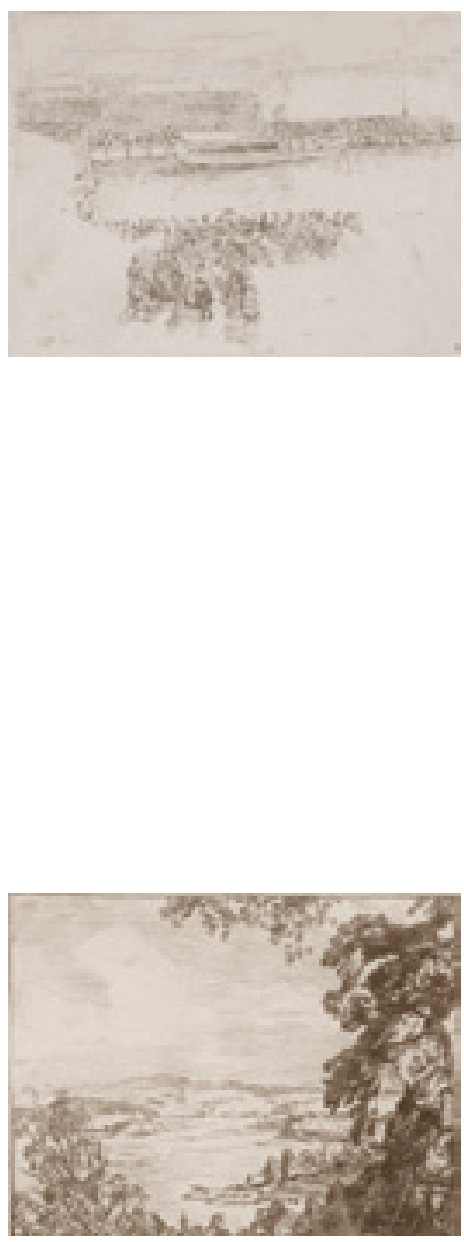
17

Fjord og fugler

1910

EW: Opus 33b

Streketsning

$317 \times 246 \mathrm{~mm}$

Signert og datert i platen o.t.v. EW 1910

Furutrærne

1910

EW: Opus 15

Streketsning $320 \times 247 \mathrm{~mm}$

Ingen signatur eller datering platen.

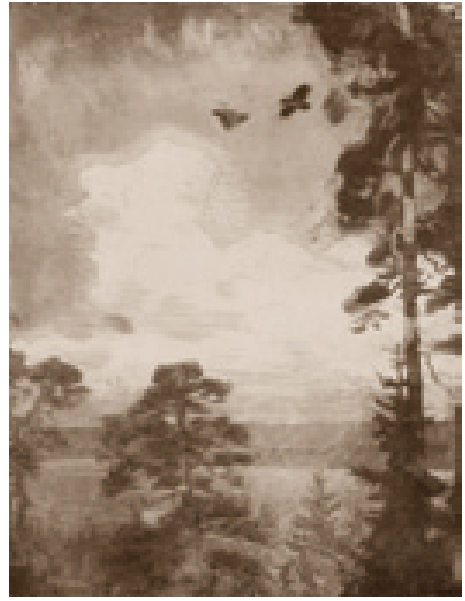

18

Eskimohunden Balto

1910

EW: Opus 14

Streketsning

$160 \times 248 \mathrm{~mm}$

Signert i platen n.t.v.: EW

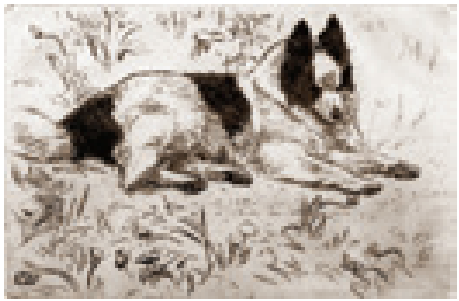

20

Bygen

1910

EW: Opus 16

Streketsning

$245 \times 315 \mathrm{~mm}$

Signert i platen n.t.v.: EW

Utsikt fra Bombakken 8 på Lysaker, hvor Erik Werenskiold bodde. Neset i forgrunnen er stedet hvor Nansens bolig "Godthåb" lå.

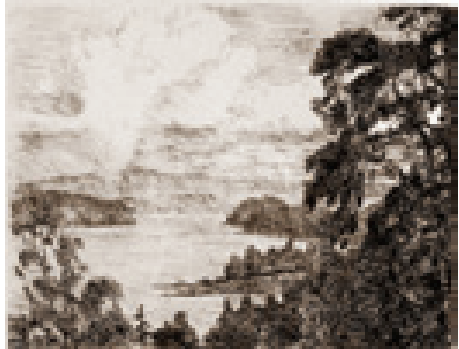


21

Smågutter som fisker

1910

EW: Opus 17

Streketsning

$249 \times 323 \mathrm{~mm}$

Signert og datert i platen o.t.v.: EW 1910

\section{Småfuru \\ 1910}

EW: Opus 19

Streketsning

$162 \times 248 \mathrm{~mm}$

Signert i platen n.t.v.: EW [speilvendt $\mathrm{E}$ ]

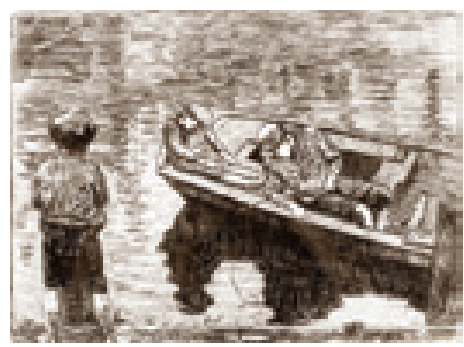

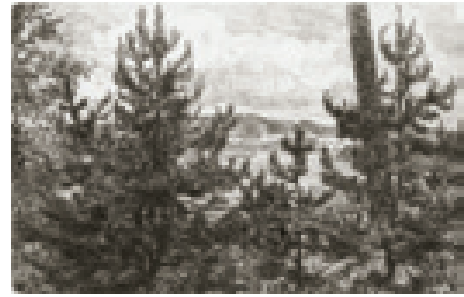

(c) KODE-Kunstmuseene i Bergen, Rasmus Meyers Samlinger. Foto: Dag Fosse/KODE.
Bjørkene ved jernbanelinjen

1910

EW: Opus 18

Streketsning

$163 \times 248 \mathrm{~mm}$

Signert i platen n.t.v.: EW

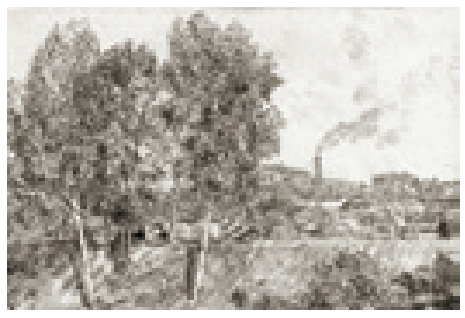

24

Trollkjerringa og de tre prinsessene

1911

EW: Opus 20

Streketsning

$251 \times 328 \mathrm{~mm}$

Signert i platen n.t.h.: EW

Opptrykk av platen i NFfGKs årsmappe 1946. Tittel: Trollet og prinsessene.

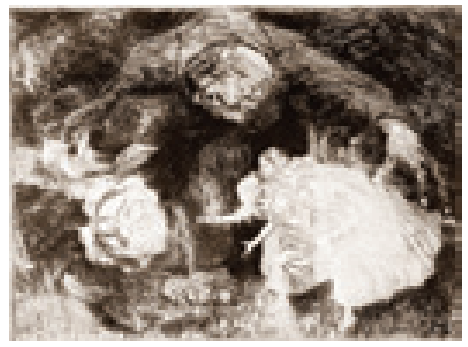


1911

EW: Opus 21

Streketsning

$249 \times 321 \mathrm{~mm}$

Signert i platen n.t.v.: EW

27

\section{Tilsnødd skog}

1911

EW: Opus 23

Streketsning

$323 \times 248 \mathrm{~mm}$

Signert i platen n.t.h.: EW

Trykkplate i forstålet kobber.
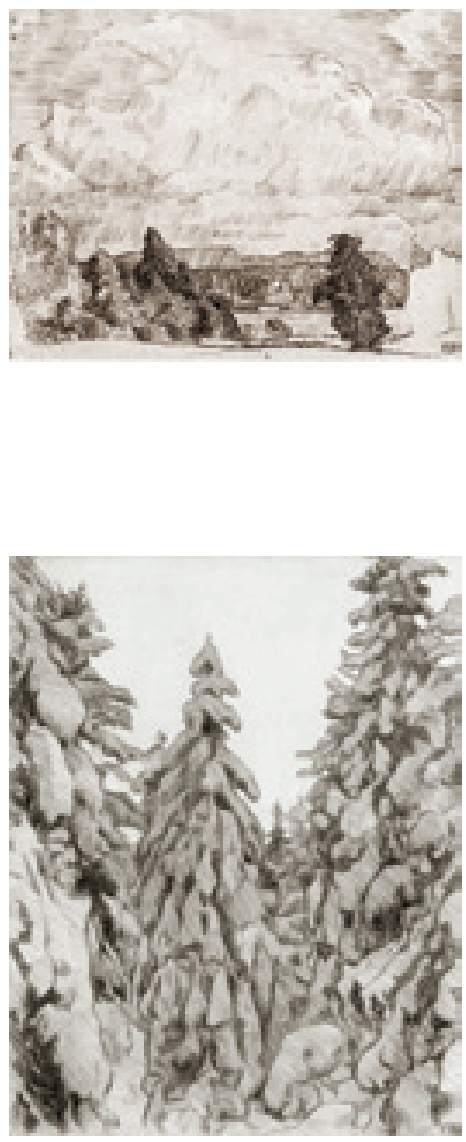

Vinternatt

1911

EW: Opus 22

Streketsning

$248 \times 321 \mathrm{~mm}$

Signert n.t.v.: EW

Opptrykk av platen ble foretatt i 1914, samtidig med Lysakerfjorden (kat.nr. 16).

\section{Gjendetrollet}

1912

EW: Opus 24

Streketsning

$247 \times 320 \mathrm{~mm}$

Signert i platen n.t.h.: EW

Etsningen har også tittelen

Løpende troll ifølge Werenskiolds notater. (c) KODE-Kunstmuseene i Bergen, Rasmus

Meyers Samlinger. Foto: Dag Fosse/KODE.
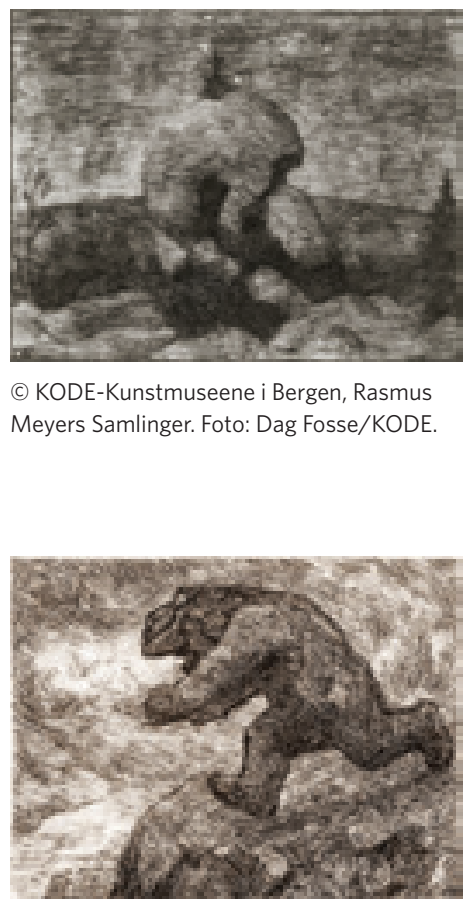
29

To gutter som skriver i bakken 1912

EW: Opus 25

Streketsning

$322 \times 246 \mathrm{~mm}$

Signert i platen n.t.h.: EW

Trykkplate i forstålet kobber.

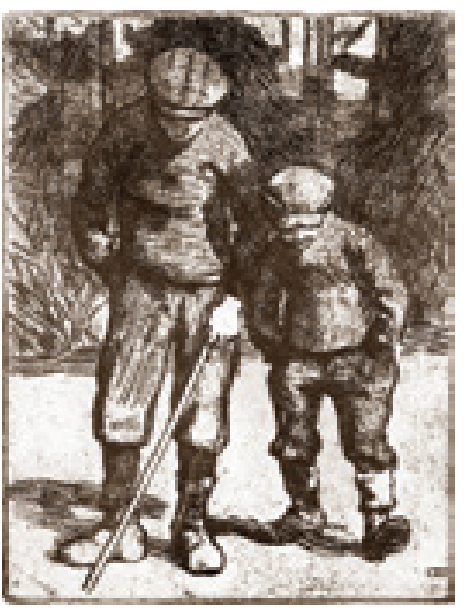

31

Furuene ved fjorden

1912

EW: Opus 33

Akvatint og streketsning $317 \times 245 \mathrm{~mm}$

Signert i platen n.t.v.: EW

Trykkplate i forstålet kobber.

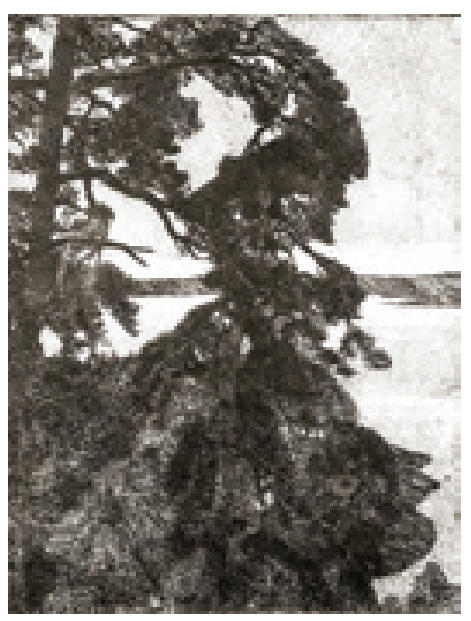

30

Opplagte båter ved Lysakerbrua 1912

EW: Opus 26

Streketsning

$246 \times 318 \mathrm{~mm}$

Signert i platen n.t.h.: EW

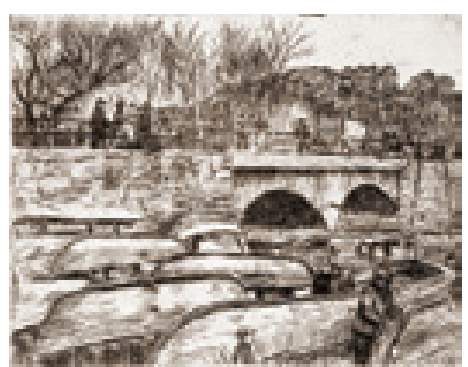

32

Gran og furu med snø på

1912

EW: Opus 31

Streketsning

$320 \times 247 \mathrm{~mm}$

Signert og datert i platen n.t.h.: EW 1912

I NFfGK, årsmappe 1945. Tittel: Skog i sne.

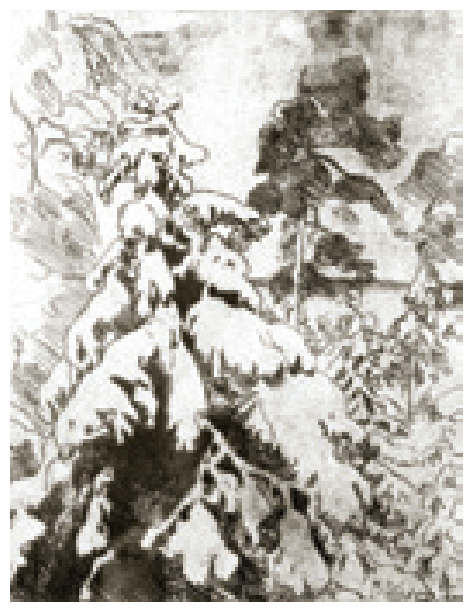


33

Gutter på ski I

1912

EW: Opus 45

Streketsning

$245 \times 315 \mathrm{~mm}$

Signert og datert i platen n.t.h.: EW 1912

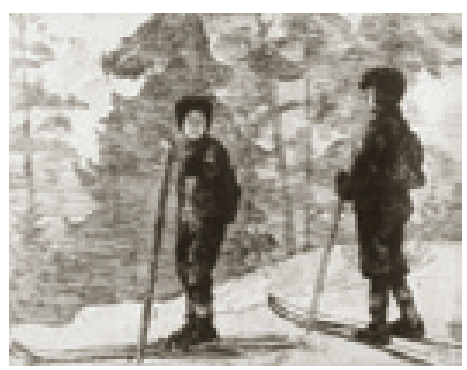

34

Gutter på ski II

1912?

EW: Uten opusnumme

Streketsning

$306 \times 157 \mathrm{~mm}$

Signert i platen n.t.v.: EW

Posthumt trykk. Forfatters tittel.

Trollpakk I

1913

EW: Opus 28

Streketsning $245 \times 318 \mathrm{~mm}$

Signert i platen n.t.h. og midt på: EW

Etsningen har også tittelen Underjordiske ifølge Werenskiolds notater.

I NFfGK, årsmappe 1945.

Tittel: Troll.
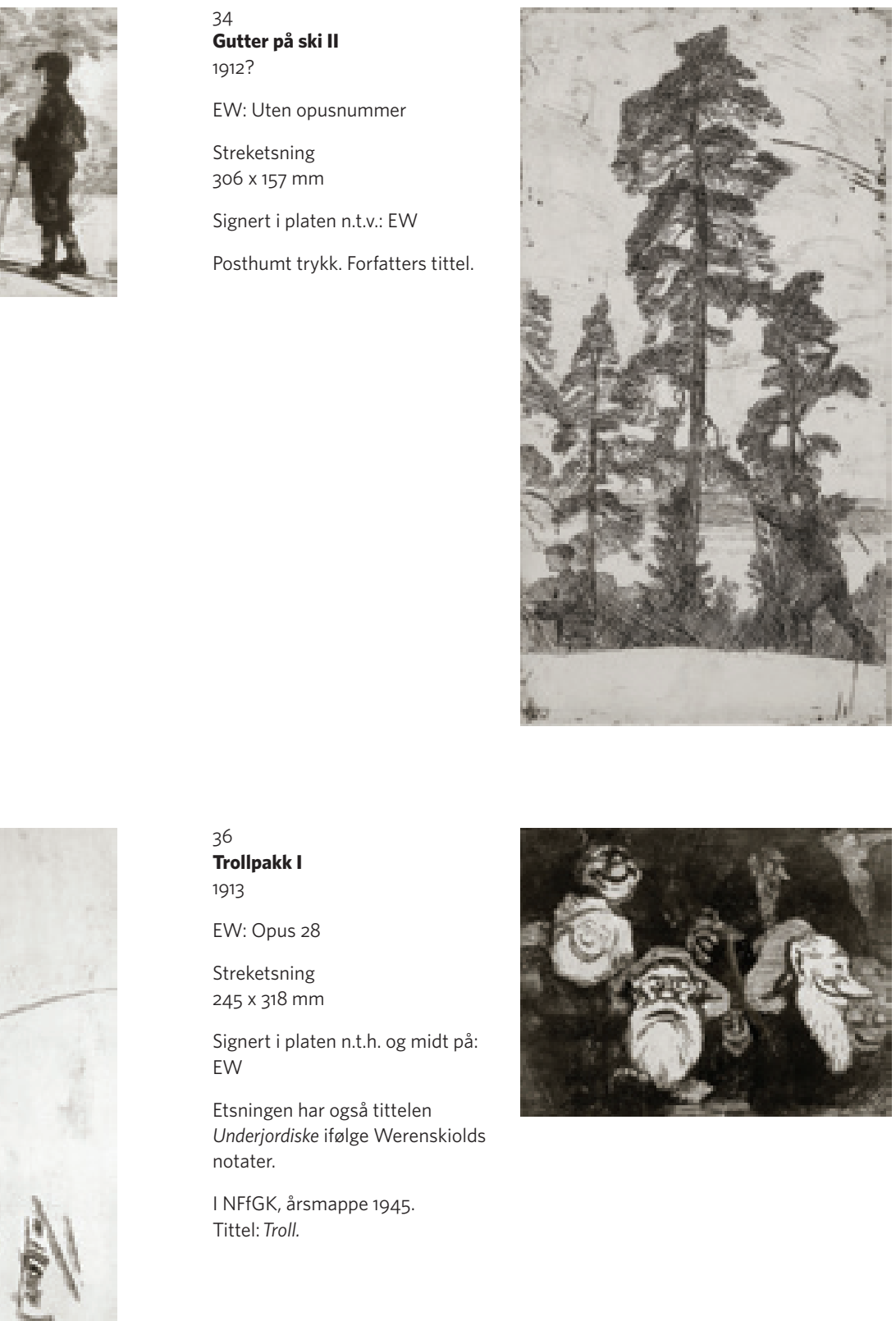
Trollpakk II

1913

EW: Opus 29

Streketsning

$245 \times 320 \mathrm{~mm}$

Signert i platen n.t.v.: EW
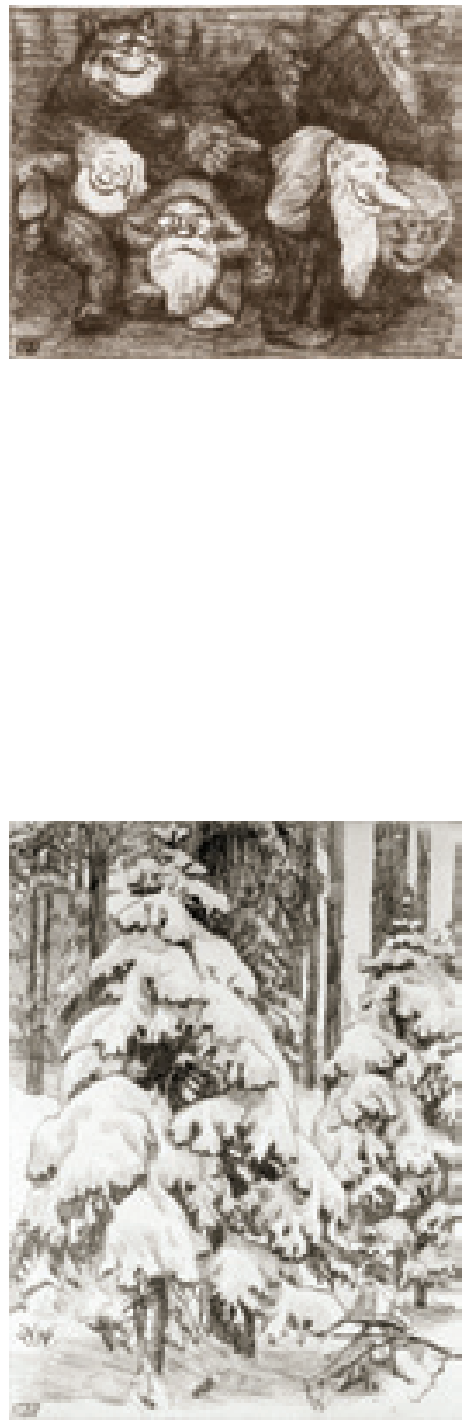

I NFfGK, årsmappe 1918. Tittel: Skogsinteriør

\section{i hånd}

1913

EW: Opus 30

Streketsning

$248 \times 161$

Signert i platen o.t.v.: EW

Etsningen har også tittelen To småjenter som leier hverandre. Noen få eksemplarer er trykt 28.6. 1914 ifølge Werenskiolds notater.

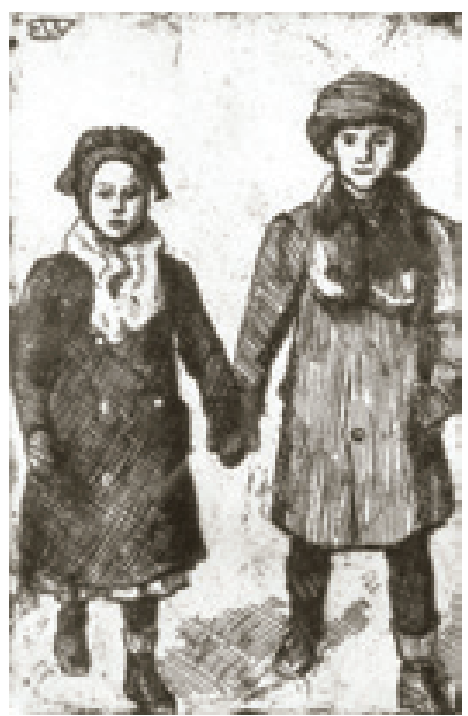

To gutter ved kakkelovnen

1913

EW: Opus 34

Streketsning

$162 \times 247 \mathrm{~mm}$

Signert i platen n.t.h.: EW

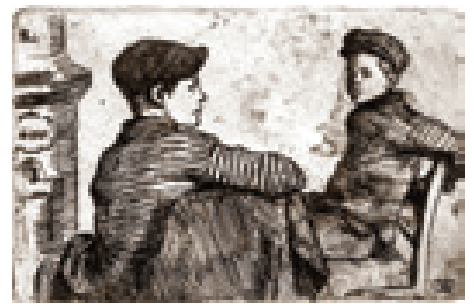


41

Halvmånen

1913

EW: Opus 35

Streketsning

$322 \times 247 \mathrm{~mm}$

Ingen signatur eller datering i platen.

Sjoa og Steinfinsbø

1913

EW: Opus 37

Streketsning

$246 \times 320 \mathrm{~mm}$

Signert i platen n.t.v.: EW

I NFfGK, årsmappe 1939 og 1946.

Tittel: Landskap
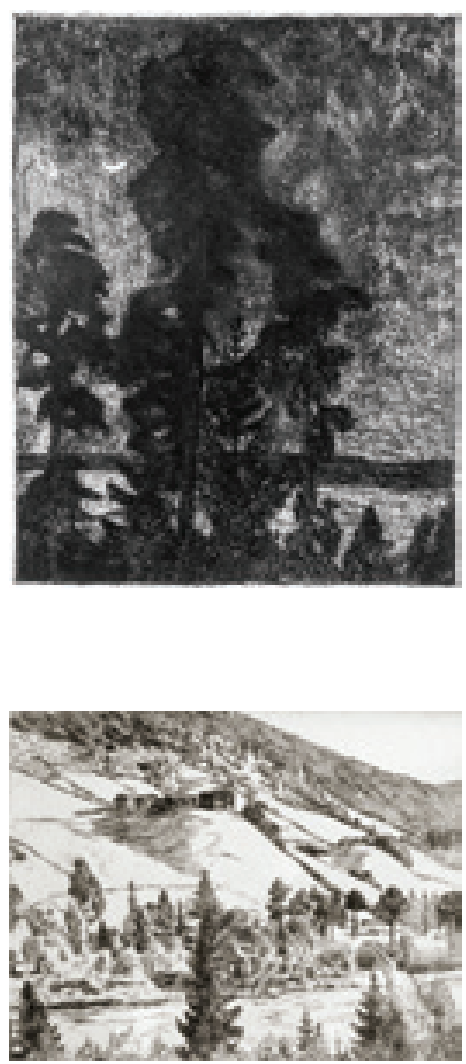

42

Steinfinsbø

1913

EW: Opus 36

Streketsning

$241 \times 303 \mathrm{~mm}$

Signert i platen n.t.h.: EW

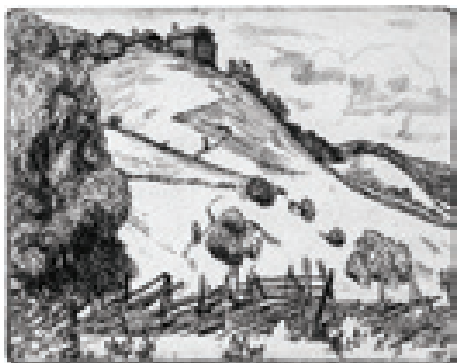

Heidalen med elva

1913

EW: Opus 38

Streketsning

$248 \times 320 \mathrm{~mm}$

Signert og datert i platen n.t.h. EW 1913

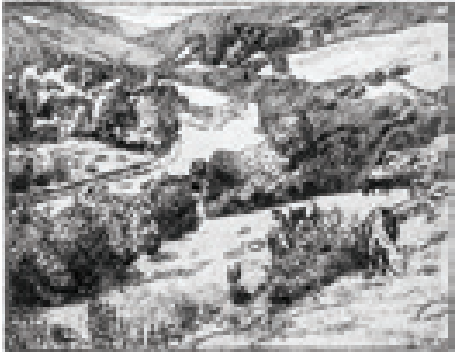


45

Skygger over Flyen

1913

EW: Opus 39

Streketsning

$248 \times 320 \mathrm{~mm}$

Signert i platen n.t.v.: EW

Etsningen ble også trykt i noen

eksemplarer 5.6.1914.

Motivet er fra traktene ved

Hindsæter i Sjoadalen med utsikt

mot Hindflyen. Til høyre

bakgrunnen ses Nautgardstind.
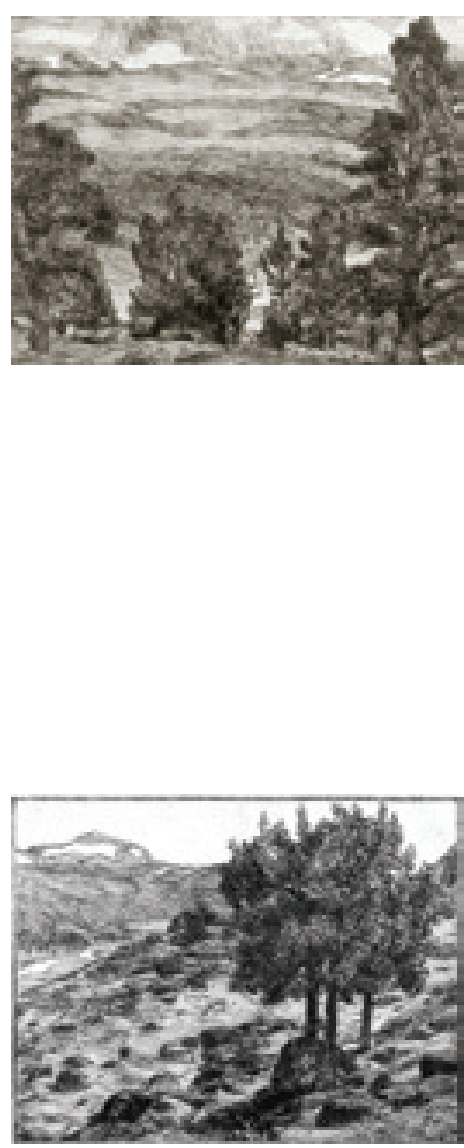

46

\section{Nautgardstind}

1913

EW: Opus 40

Streketsning

$246 \times 317 \mathrm{~mm}$

Signert i platen n.t.v.: EW

Werenskiolds påskrift på dette trykket: "1 stk. prøve Fort Paris."

Sannsynligvis finnes det svært få trykk av denne etsningen. Platen ble forsøkt etset en gang til etter prøvetrykket, men ble ødelagt i syrebadet. I oktober 1913 skal

Werenskiold ha levert ytterligere 10 plater til trykking i Rue 289 St. Jaques i Paris, men prosjektet var mislykket.

48

Kua på sætra

1913

EW: Opus 42

Streketsning

$248 \times 323 \mathrm{~mm}$

Ingen signatur eller datering i platen.
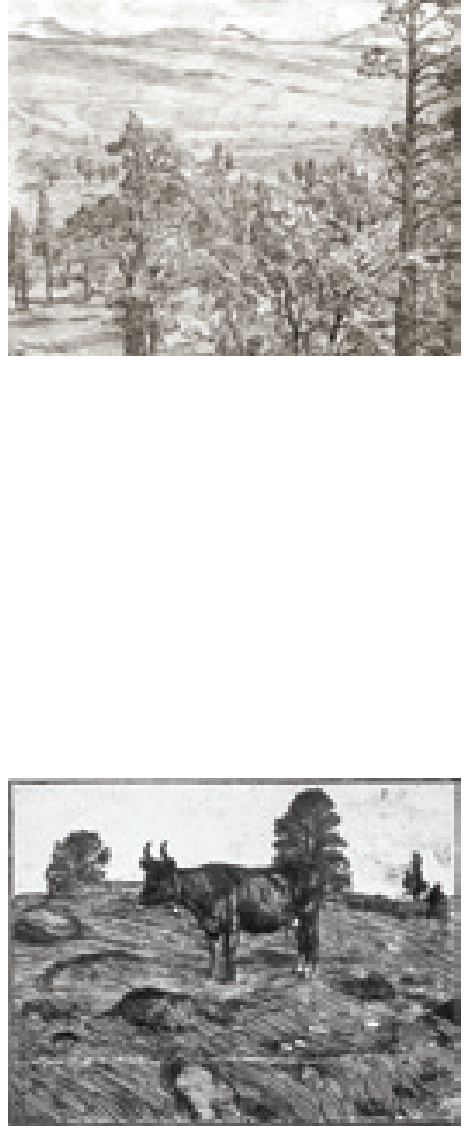
49

essh

1913

EW: Opus 43

Streketsning

$248 \times 317 \mathrm{~mm}$

Signert i platen n.t.h.: EW

Etsningen ble også trykt i to eksemplarer 5.6. 1914.

51

Frederik Collett I

1913

EW: Opus 46

Streketsning

$320 \times 247 \mathrm{~mm}$

Signert i platen n.t.v.: EW

Maleren Frederik Collett

(1839-1914) var en av de første kunstnerne fra Norge som reiste til Frankrike på 1800-tallet.

Et eksemplar av etsningen ble gitt som fødselsdagshilsen til Collett på 75-årsdagen 23.3. 1914

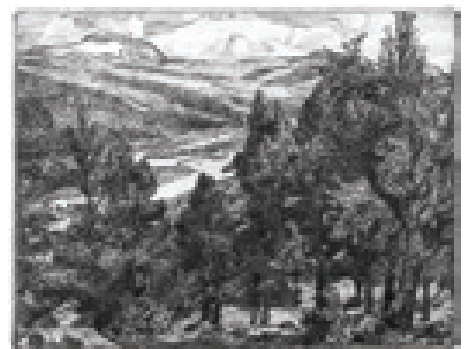

Furuene på Hindsæter

1913

EW: Opus 44

Streketsning

$299 \times 236 \mathrm{~mm}$

Signert i platen n.t.h.: EW

Etsningen skal ifølge

Werenskiolds notater finnes i bare ett eksemplar.

52

\section{Frederik Collett II}

1913

EW: Opus 47

Streketsning

$322 \times 252 \mathrm{~mm}$

Signert i platen n.t.v.: EW

Etsningen er også trykt i fire eksemplarer 5.6.1914 ifølge

Werenskiolds håndskrevne notater

Maleren Frederik Collett

(1839-1914) var en av de første

kunstnerne fra Norge som reiste til Frankrike på 1800-tallet.
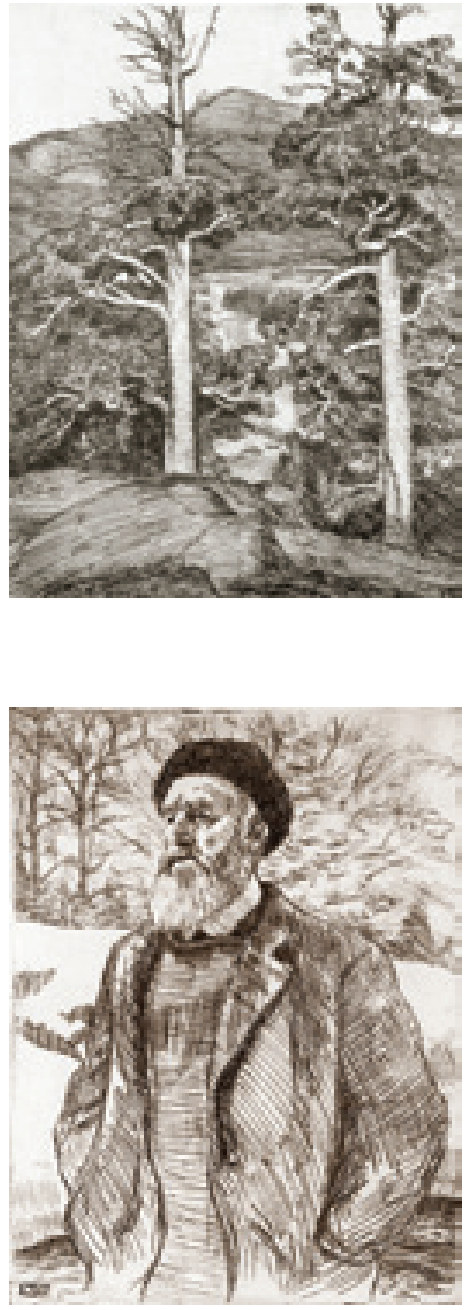


\section{3}

EW: Opus 48

Streketsning

$162 \times 243 \mathrm{~mm}$

Signert i platen n.t.v.: EW
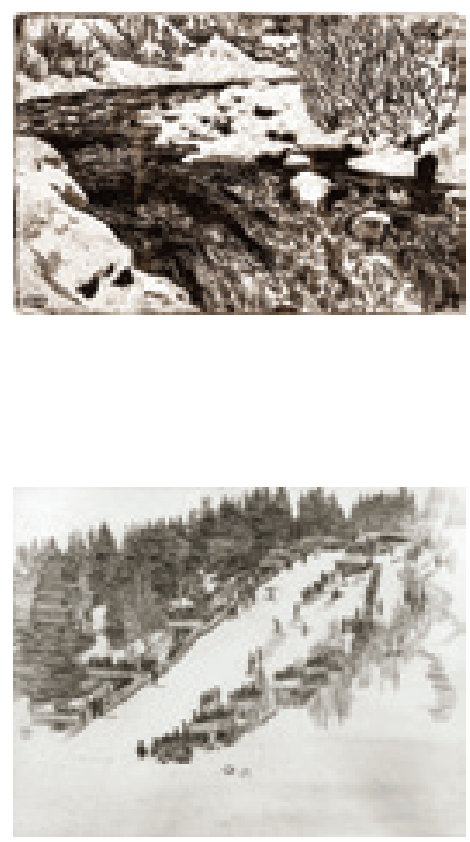

54

1914

EW: Opus 49

Streketsning

$249 \times 320 \mathrm{~mm}$

Signert i platen n.t.h.: EW

Smågran og furustammer 1914

EW: Opus 51

Streketsning

$249 \times 318 \mathrm{~mm}$

Signert i platen n.t.v.: EW

Trykkplate i forstålet kobber
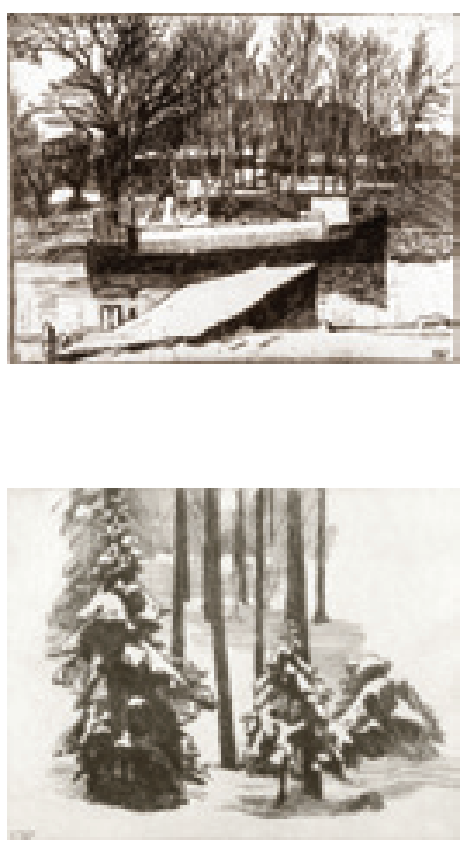

Solbergbakken i Bærum var et samlingssted for skihoppere både

lokalt og nasjonalt på slutten av

1800-tallet og langt inn på

1900-tallet. Her arrangerte

Bærum skiklubb årlige renn hvor

hele landets hoppelite var til

stede. Bare Holmenkollrennet

hadde større oppslutning og

høyere prestisje enn

Solbergrennet på denne tiden. 
1914

EW: Opus 52

Streketsning

$238 \times 302 \mathrm{~mm}$

Signert i platen n.t.h.: EW

Trykkplate i forstålet kobber.
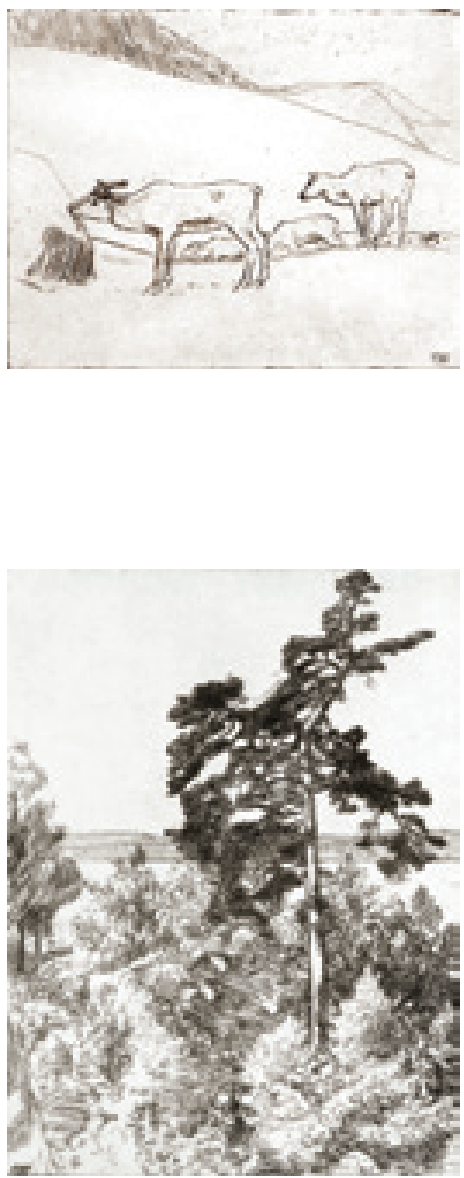

Trykkplate i nikkelbelagt kobber
58

Hans E. Kinck I

1914

EW: Opus 53

Streketsning

$248 \times 321 \mathrm{~mm}$

Signert i platen t.v.: EW

Trykkplate i forstålet kobber.

Hans Ernst Kinck (1865-1926) var romanforfatter, dramatiker, lyriker og en allsidig essayist.

\section{Syv søstre}

1914

EW: Opus 55

Streketsning

$246 \times 320 \mathrm{~mm}$

Signert i platen n.t.h.: EW
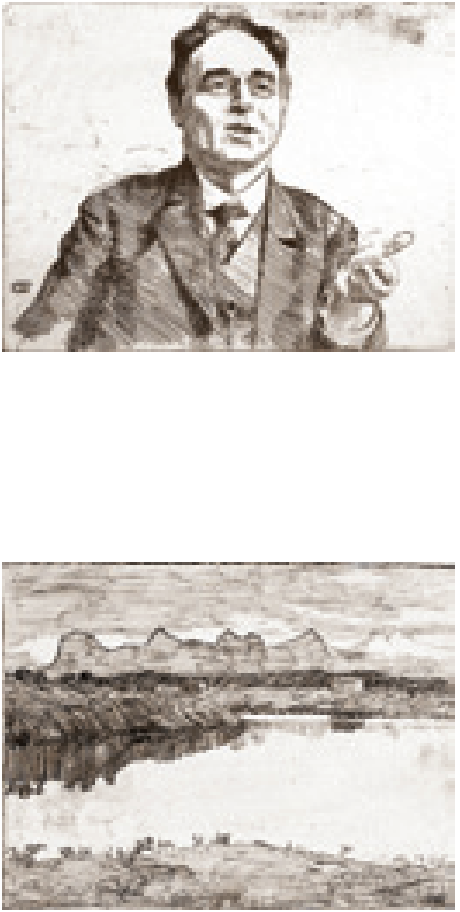


\section{Fra Kabelvåg}

1914

EW: Opus 56

Streketsning $245 \times 318 \mathrm{~mm}$

Signert i platen n.t.v.: EW

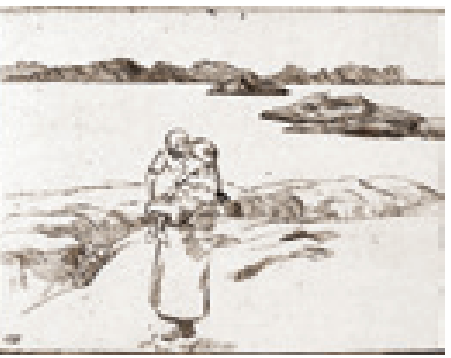

63

\section{Hans Mustad II}

1915

EW: Opus $67 a$

Streketsning

$324 \times 247 \mathrm{~mm}$

Signert i platen n.t.v.: EW

Hans Mustad (1837-1918) var

industrieier. Sammen med sin far, Ole Mustad, eide han bl.a. en stor jernvarebedrift på Gjøvik. Mustad \& Søn A/S flyttet på slutten av 180o-tallet deler av produksjonen til Lysaker.

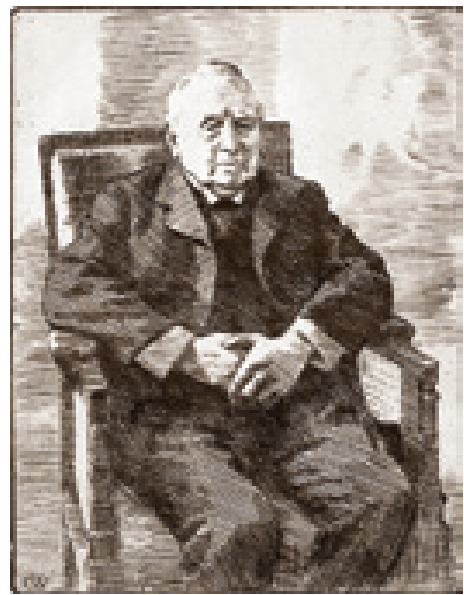

62

Hans Mustad I

mars 1915

EW: Opus 57

Streketsning

$249 \times 323 \mathrm{~mm}$

Signert og datert o.t.v.: EW // 1915

Hans Mustad (1837-1918) var

industrieier. Sammen med sin far, Ole Mustad, eide han bl.a. en stor jernvarebedrift på Gjøvik. Mustad

\& Søn A/S flyttet på slutten av

1800-tallet deler av produksjonen

til Lysaker.

\section{4}

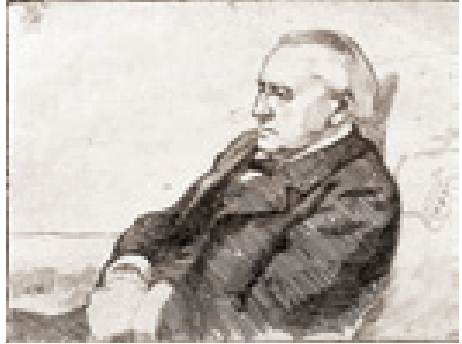

\section{Hans Mustad III}

1915

EW: Opus 67b

Streketsning

$249 \times 322 \mathrm{~mm}$

Signert i platen o.t.v.: EW

Hans Mustad (1837-1918) var

industrieier. Sammen med sin far, Ole Mustad, eide han bl.a. en stor jernvarebedrift på Gjøvik. Mustad \& Søn A/S flyttet på slutten av 1800-tallet deler av produksjonen til Lysaker.

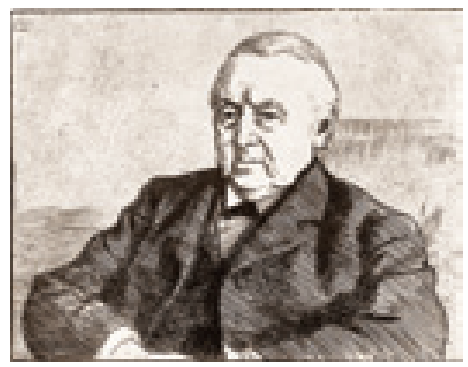




\section{Hans Mustad IV}

1915

EW: Opus $67 c$

\section{Streketsning}

$324 \times 247 \mathrm{~mm}$

Signert i platen o.t.v.: EW

Hans Mustad (1837-1918) var industrieier. Sammen med sin far, Ole Mustad, eide han bl.a. en stor jernvarebedrift på Gjøvik. Mustad \& Søn A/S flyttet på slutten av 1800-tallet deler av produksjonen til Lysaker.

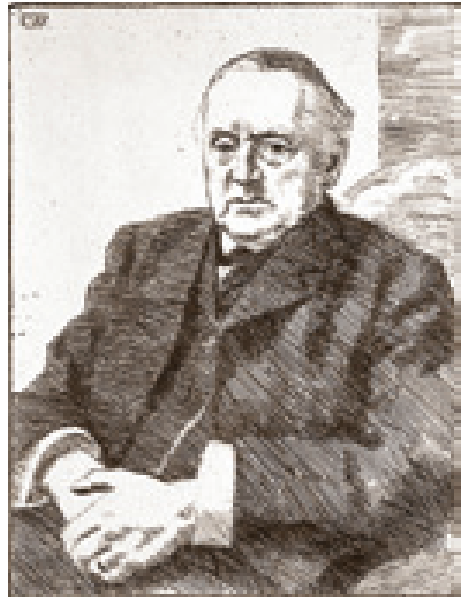

66

Hunelven

1915

EW: Opus 58

\section{Streketsning} $320 \times 250 \mathrm{~mm}$

Signert i platen n.t.v.: EW

\section{Unghest med sele på}

1915

EW: Opus 59

Streketsning

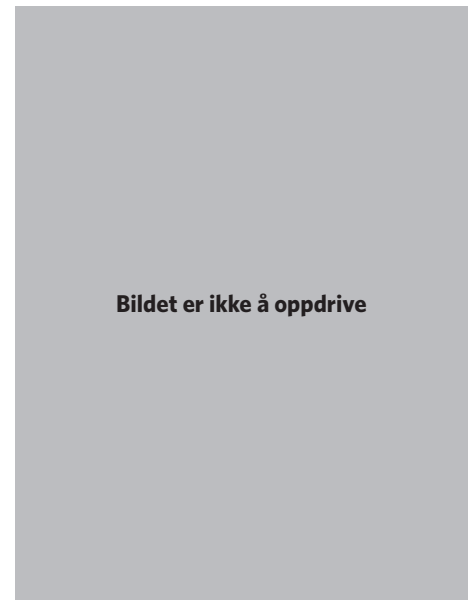

68

Thorvald Heiberg

april 1915

EW: Opus 60

Streketsning

$322 \times 247 \mathrm{~mm}$

Signert i platen n.t.v.: EW

Thorvald Meyer Heiberg (1875-1961), sønn av Axel og Ragnhild Heiberg. I 1919 overtok han gården Kiærnsmo i Nes på Romerike, etter sin tante Agnes Meyer, datter av trelast-handler

Thorvald Meyer i Kristiania. I 1901 giftet han seg med Julie Aubert. På et av sine mange

vinteropphold i Agadir i Marokko opplevde han i 1960 at byen ble ødelagt av jordskjelv, et av de største i byens historie.
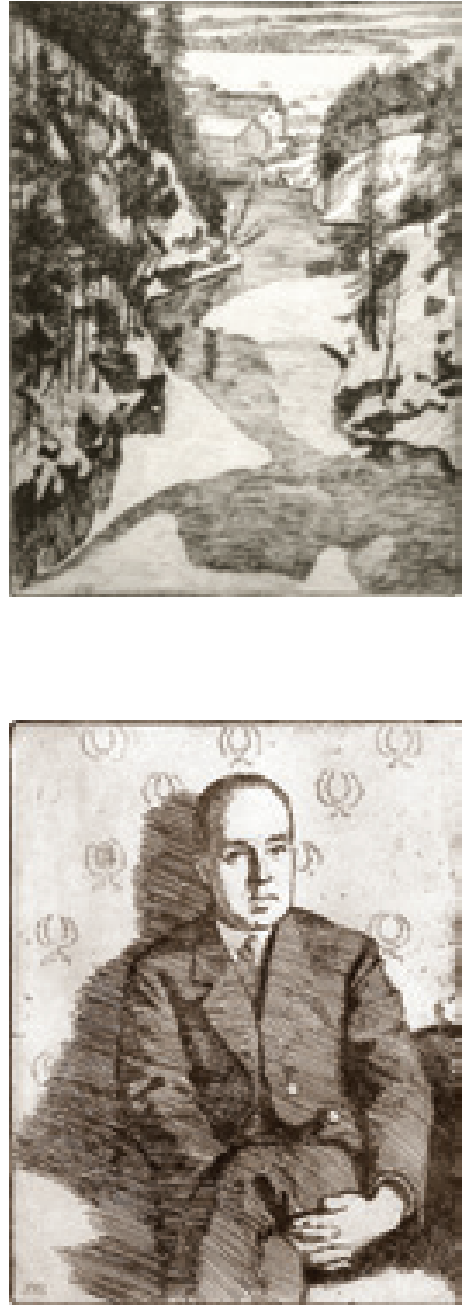
69

\section{Axel Heiberg}

mai 1915

EW: Opus 61

Streketsning

$324 \times 249 \mathrm{~mm}$

Signert i platen n.t.v.: EW

Trykkplate i forstålet kobber.

Axel Heiberg (1848-1932) var medeier i flere norske bedrifter, bl.a. Ringnes Bryggerier. Han var mesen for en rekke norske kunstnere og vitenskapsmenn. Han støttet Nansens Framekspedisjon og tok i 1896 initiativet til opprettelsen av Fridtjof Nansens fond til

vitenskapens fremme.

Skulpturene av Henrik Ibsen og Bjørnstjerne Bjørnson utenfor

Nationaltheatret var en gave fra Axel Heiberg, gitt i 1899. Erik

Werenskiold var en av de

kunstnerne som fikk nyte godt av hans mesenvirksomhet.

\section{Fru Emma Stang II}

1915

EW: Uten opusnummer

Streketsning

$323 \times 248 \mathrm{~mm}$

Ingen signatur eller datering i platen.

Emma Stang (1874-1927), datter av Axel og Ragnhild Heiberg. Emma Heiberg giftet seg med Ole Andreas Stang i 1895. I 1925 ble hun overhoffmesterinne hos dronning Maud. Axel Heibergs barn er tremenninger til kunstneren Jean Heiberg.

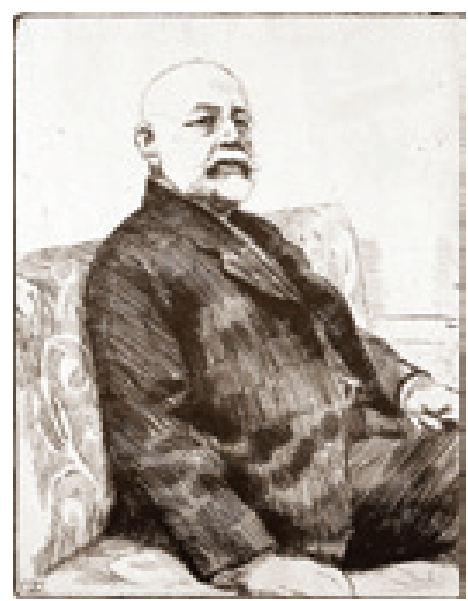

70

Fru Emma Stang I

1915

EW: Opus 62

Streketsning

$322 \times 247 \mathrm{~mm}$

Signert og datert i platen n.t.v.: EW 1915

Emma Stang (1874-1927), datter av Axel og Ragnhild Heiberg. Emma Heiberg giftet seg med Ole Andreas Stang i 1895. I 1925 ble hun overhoffmesterinne hos dronning Maud. Axel Heibergs barn er tremenninger til kunstneren Jean Heiberg.

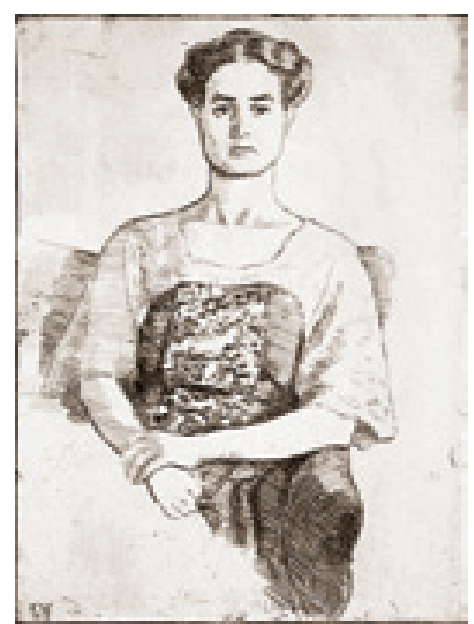

72

Fru Emma Stang III

1915

EW: Uten opusnummer

Streketsning

$323 \times 248 \mathrm{~mm}$

Signert i platen o.t.v.: EW

Emma Stang (1874-1927), datter av Axel og Ragnhild Heiberg. Emma Heiberg giftet seg med Ole Andreas Stang i 1895. I 1925 ble

hun overhoffmesterinne hos dronning Maud. Axel Heibergs barn er tremenninger til kunstneren Jean Heiberg.

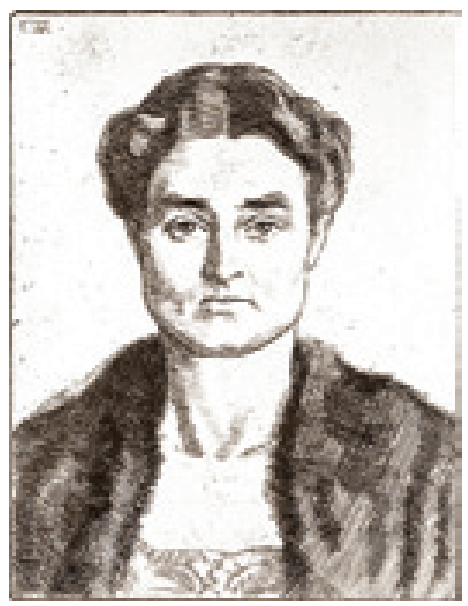


73

\section{Fru Ingeborg Fearnley}

1915

EW: Opus 63

Streketsning

$322 \times 247 \mathrm{~mm}$

Signert i platen o.t.h.: EW

Trykkplaten i forstålet kobber.

Ingeborg Fearnley (1884-1974), datter av Axel og Ragnhild Heiberg, giftet seg med Nils Fearnley i 1906.
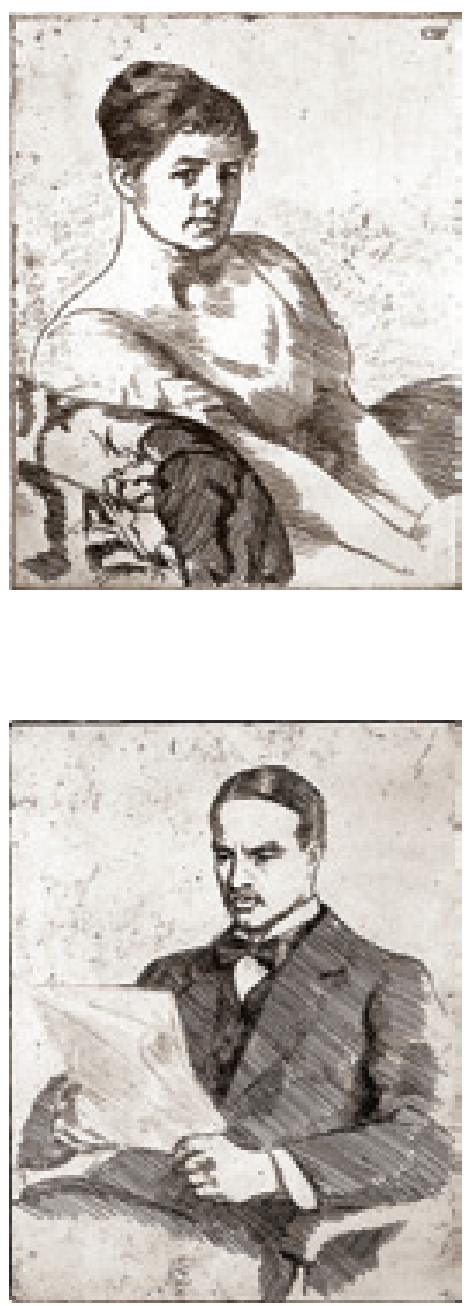

74

\section{Fru Ragnhild Heiberg}

januar 1916

EW: Opus 64

Streketsning

$322 \times 245 \mathrm{~mm}$

Signert i platen o.t.v.: EW

Trykkplaten i forstålet kobber.

Ragnhild Heiberg (1849-1937), datter av trelasthandler Thorvald Meyer, giftet seg med Axel

Heiberg i 1873

76

Fru Emma Stang IV

januar 1916

EW: Opus 66

Streketsning

$322 \times 247 \mathrm{~mm}$

Signert og datert i platen o.t.h. EW // 1916

Trykkplate i forstålet kobber.

Emma Stang (1874-1927), datter av Axel og Ragnhild Heiberg. Emma Heiberg giftet seg med Ole Andreas Stangi 1895. I 1925 ble hun overhoffmesterinne hos dronning Maud. Axel Heibergs barn er tremenninger til kunstneren Jean Heiberg.
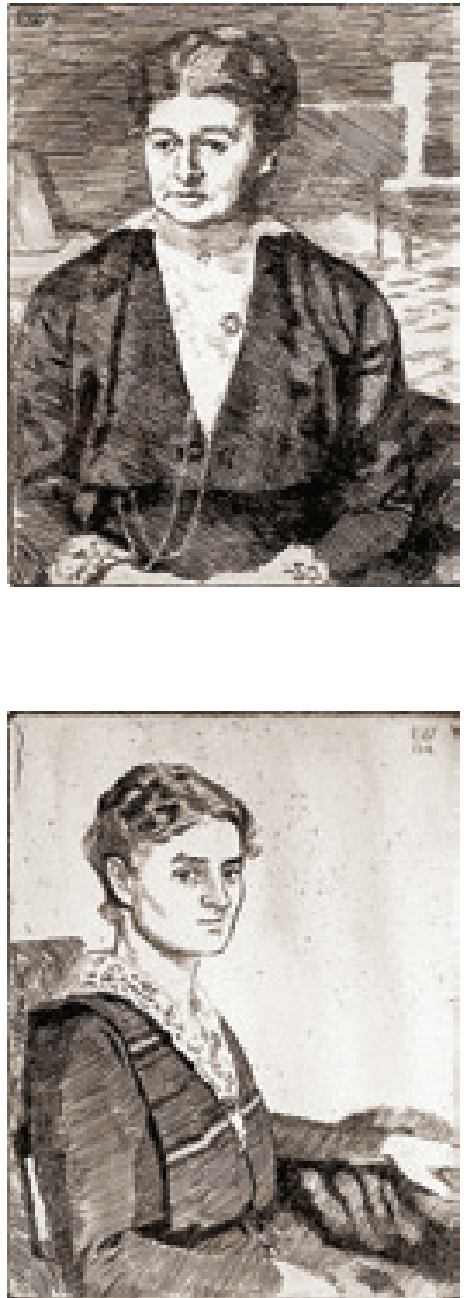
77

\section{Ellef maler}

1916

EW: Opus 68

Streketsning og akvatint $320 \times 248 \mathrm{~mm}$

Ingen signatur eller datering i platen

Posthumt trykk
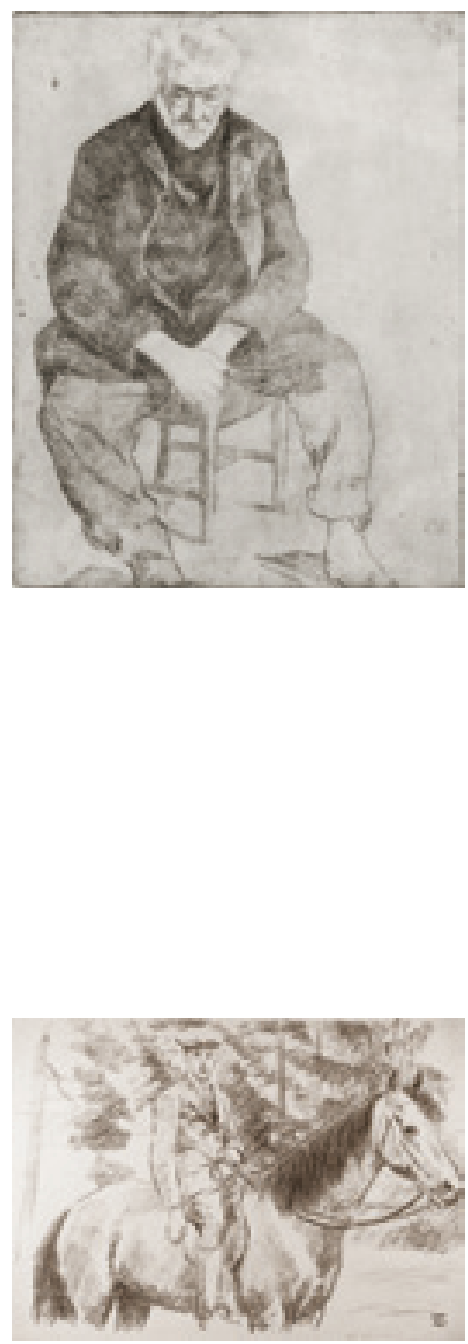

\section{Fabrikkpipen}

1917

EW: Opus 1

Litografi

$265 \times 338 \mathrm{~mm}$

Signert i steinen n.t.h.: EW

Litografiet viser Høvik Verk, eller "Glassverket" som det ble kalt i omegnen. Høvik Verk ble etablert i 1855 av engelskmannen Thomas Graham Smyth. Glasshytten ble bygget for produksjon av flasker. Pipen ble et "landemerke" og raget 35 meter til værs. I boken Bærum. En bygds historie, bind II kan man lese at "flaskerne derfra var meget stygge, av en skidden sort farve". Verket ble i 1862 kjøpt opp av brødrene Harald, Ole og Nils Berg som fra for eide flere glassverk, bl.a. Hadeland

Glassverk. I tillegg til en utvidet flaskeproduksjon ble lampeglass og lykter en viktig del av produksjonen.

80

Melkehesten

1918

EW: Opus 3

Litografi $330 \times 256 \mathrm{~mm}$

Ingen signatur eller datering $\mathrm{i}$ steinen.
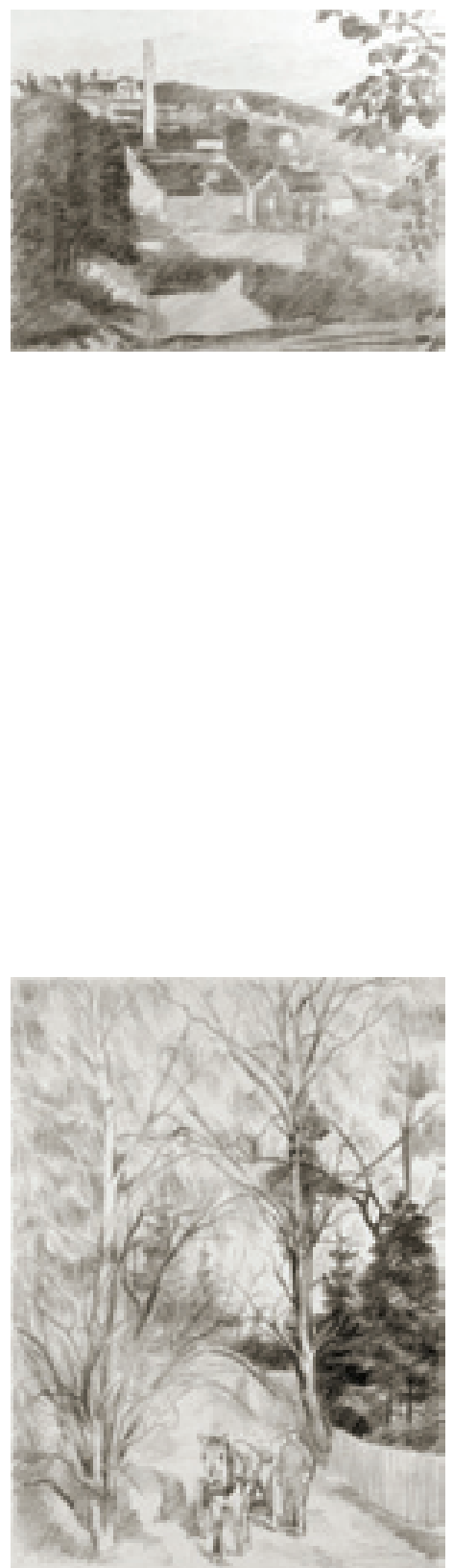

Anton Fredrik Klaveness

(1903-1981) ble skipsreder. Han var sønn av skipsreder Anton Fredrik og Therese Klaveness, født Grøn. 
81

Kvinner

1918?

EW: Opus $70 a$

Streketsning

$243 \times 321 \mathrm{~mm}$

Ingen signatur eller datering i platen.

Ikke fullført plate.

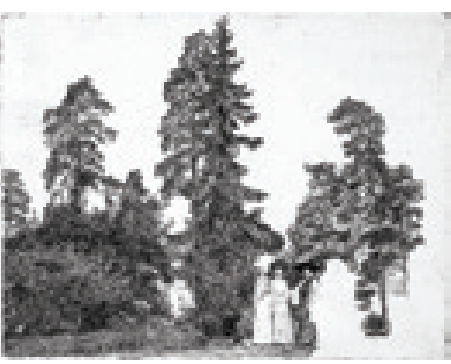

83

Saga I

1918?

EW: Opus $70 b$

Streketsning

$162 \times 247 \mathrm{~mm}$

Ingen signatur eller datering i platen.

Akvarell med tilnærmet samme motiv ble malt i 1918. Akvarellen har en dekorativ bord i nedre bildekant.

82

\section{Dagfin I}

1918?

EW: Opus 72

Strekestning

$250 \times 162 \mathrm{~mm}$

Ingen signatur eller datering i platen.

Ikke fullført plate.

Dagfin Werenskiold (1892-1977) kunstner og sønn av Erik og Sophie Marie Werenskiold, født Stoltenberg Thomesen.

84

Setningsbygninga e'kje rekti

1918 ?

EW: Uten opusnummer

Streketsning

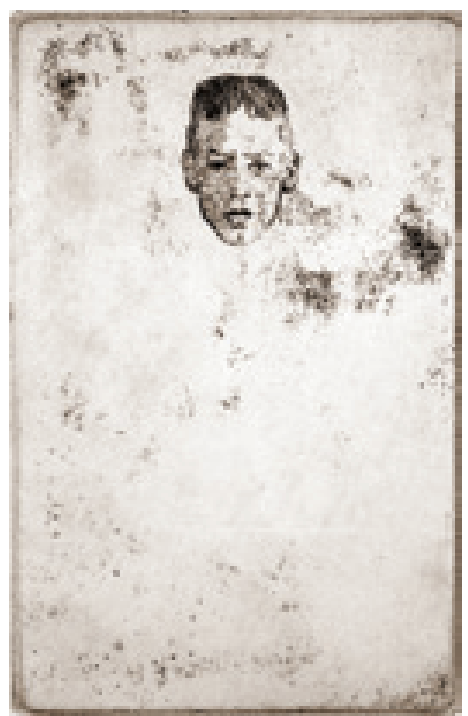

Bildet er ikke å oppdrive

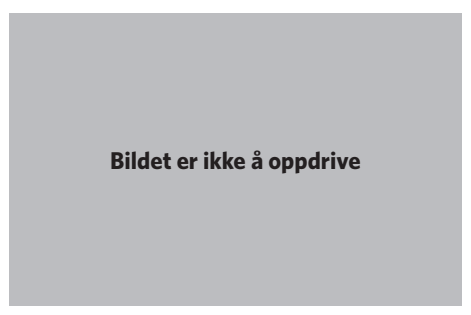


Kjelken

$1918 ?$

EW: Uten opusnummer

Streketsning

87

Borgermester Hagbart Berner 1918

EW: Opus 4

Litografi

$360 \times 240 \mathrm{~mm}$

Ingen signatur eller datering i steinen.

Hagbart Emanuel Berner

(1839-1920) var utdannet jurist. I tidsrommet 1869-1879 var han redaktør i Dagbladet som ble

Venstres hovedorgan. Sammen med Gina Krog stiftet han Norsk Kvindesagsforening i 1884 og var foreningens første formann.
Gutter slår ball

1918 ?

EW: Uten opusnummer

Streketsning

\section{Bildet er ikke å oppdrive}

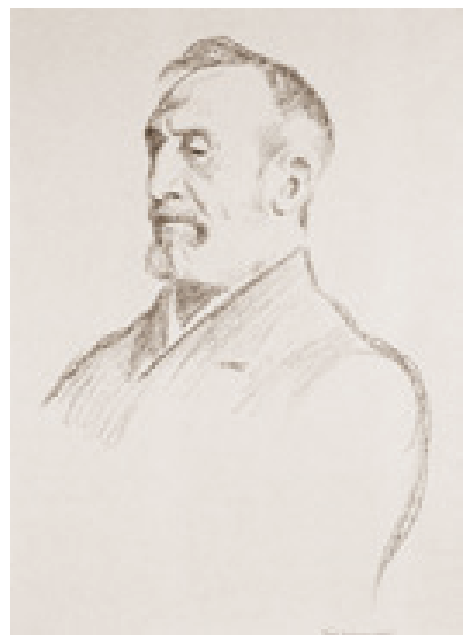

Borgermester Hagbart Berner II 1918

\section{EW: Opus 5}

Litografi

$250 \times 220 \mathrm{~mm}$

Ingen signatur eller datering $\mathrm{i}$ steinen.

Hagbart Emanuel Berner

(1839-1920) var utdannet jurist. tidsrommet 1869-1879 var han redaktør i Dagbladet som ble Venstres hovedorgan. Sammen med Gina Krog stiftet han Norsk Kvindesagsforening i 1884 og var foreningens første formann.
Bildet er ikke å oppdrive
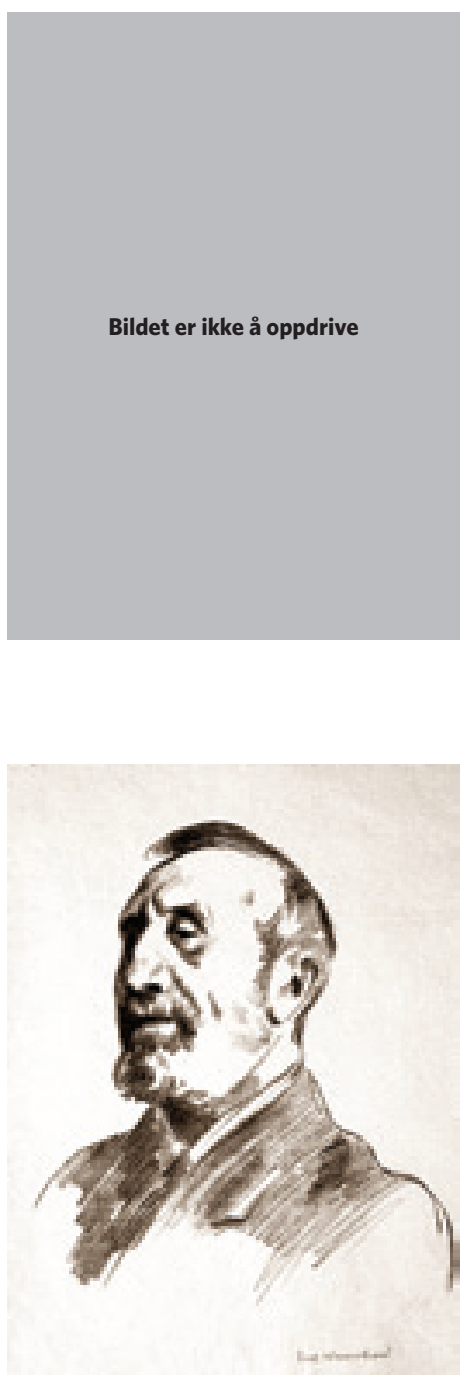


\section{Gutt med skinnlue}

1918

EW: Opus 6

Litografi

$356 \times 229 \mathrm{~mm}$

Ingen signatur eller datering steinen.

Granen som bøyer seg for

\section{vinden}

1918

EW: Opus 8

Litografi

$322 \times 248 \mathrm{~mm}$

Signert i steinen n.t.v.: EW

Litografiet har også tittelen Stormen og Gran i storm ifølge Werenskiolds notater.

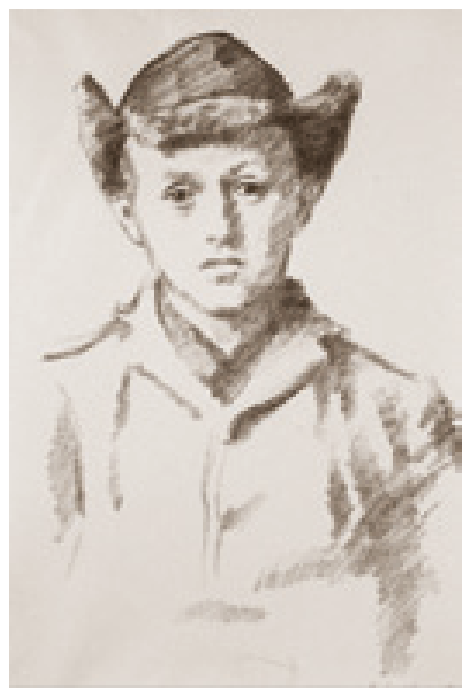

\section{0}

Nakne lindetrær

1918

EW: Opus 7

Litografi

$437 \times 260 \mathrm{~mm}$

Ingen signatur eller datering i steinen.

Inga

1918

EW: Opus 9

Litografi
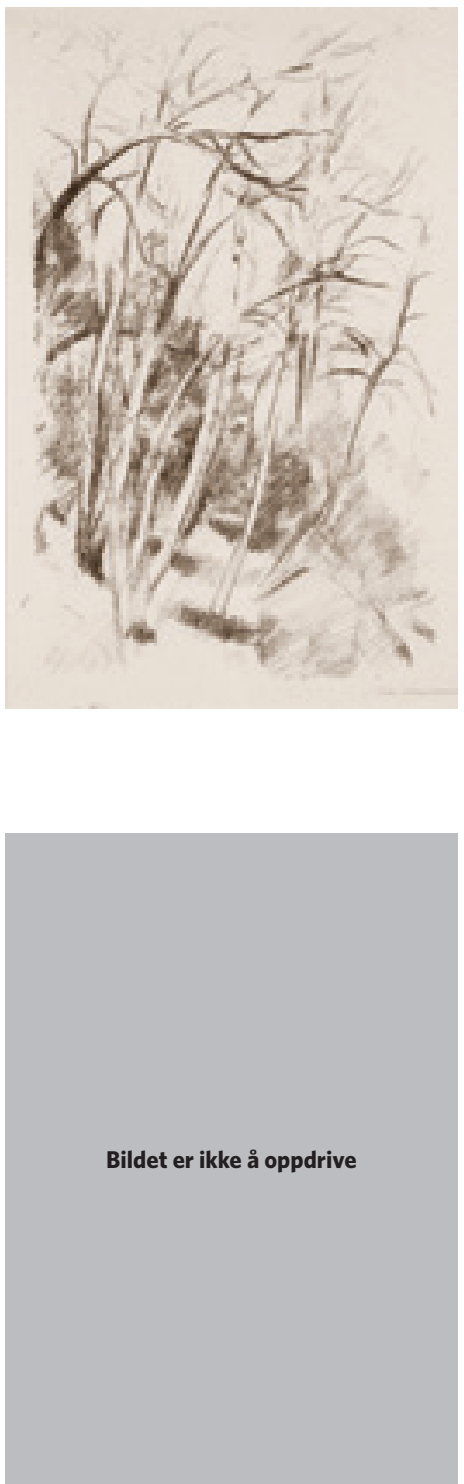
93

gfin og Beth I

1918

EW: Opus 10

Litografi

$650 \times 860 \mathrm{~mm}$

Signert i steinen n.t.h.: EW

Dagfin Werenskiold (1892-1977), kunstner og sønn av Erik og

Sophie Marie Werenskiold, født

Stoltenberg Thomesen. Dagfin

var gift med Elisabeth ("Beth")

Mathilde, født Schram

(1897-1989).

\section{Dagfin og Beth II}

1918

Opus 12

Litografi

Et mindre format enn Dagfin og Beth I, kat.nr. 93.

Dagfin Werenskiold (1892-1977), kunstner og sønn av Erik og

Sophie Marie Werenskiold, født

Stoltenberg Thomesen. Dagfin

var gift med Elisabeth ("Beth")

Mathilde, født Schram

(1897-1989).

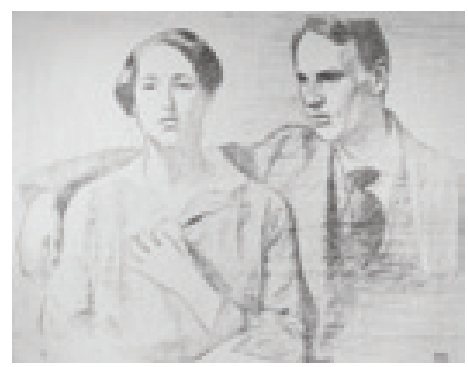

94

Lillegutt

1918

EW: Opus 11

Litografi

Motivet er et portrett av Jens Erik Werenskiold, Erik Werenskiolds barnebarn.

Svingen

1918

EW: Opus 13

Litografi
Bildet er ikke å oppdrive

8
: Opus 13
ografi

Bildet er ikke å oppdrive
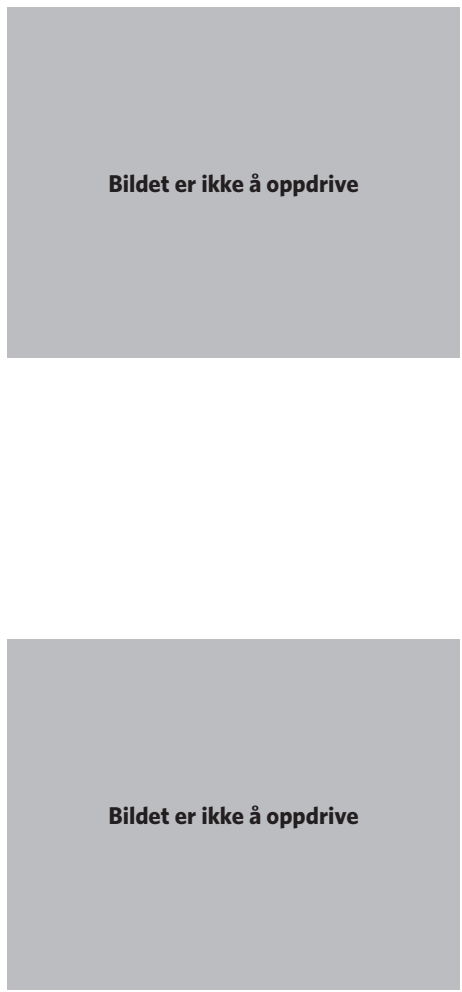

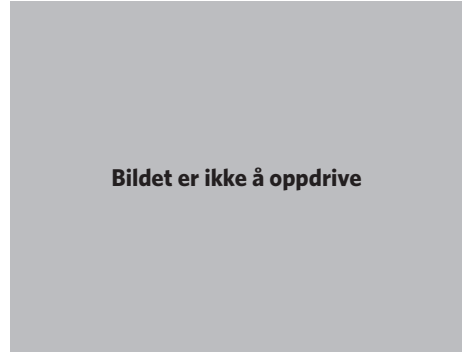


Seilbåten mellom trærne I

1918 ?

EW: Uten opusnumme

Litografi

$415 \times 250 \mathrm{~mm}$

Ingen signatur eller datering $\mathrm{i}$ steinen.

Utsikt fra området på Lysake hvor Erik Werenskiold bodde fra 1896. Hans hjem lå i Bombakken 8 ("Gilje").

\section{9}

Hoppe tau I

1918

EW: Opus 15

Litografi

$330 \times 225 \mathrm{~mm}$

Ingen signatur eller datering steinen.

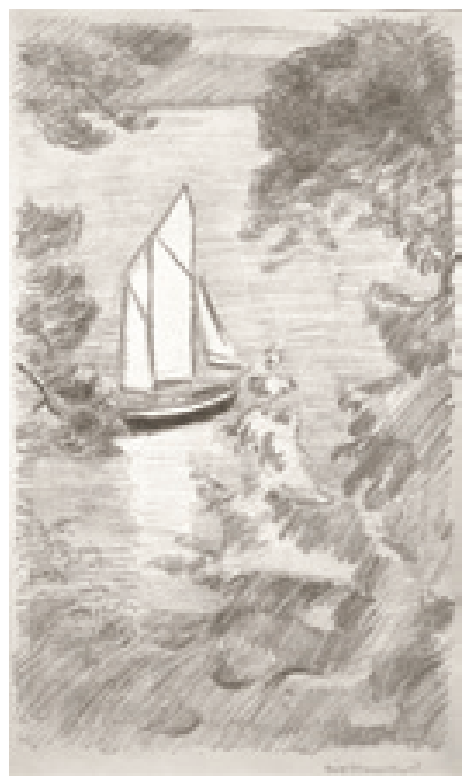

98

Seilbåten mellom trærne II

1918

EW: Opus 14

Litografi

$327 \times 242 \mathrm{~mm}$

Ingen signatur eller datering $\mathrm{i}$ steinen.

Utsikt fra området på Lysaker hvor Erik Werenskiold bodde fra 1896. Hans hjem lå i Bombakken 8 ("Gilje").

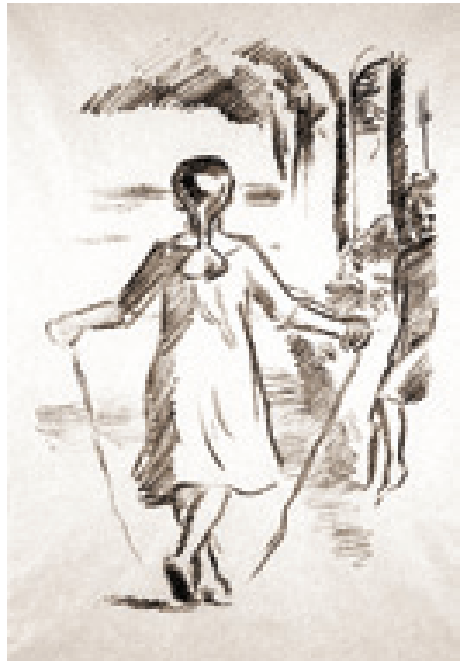

100

Hoppe tau II

1918

EW: Opus 16

Litografi

$402 \times 250 \mathrm{~mm}$

Ingen signatur eller datering i steinen.
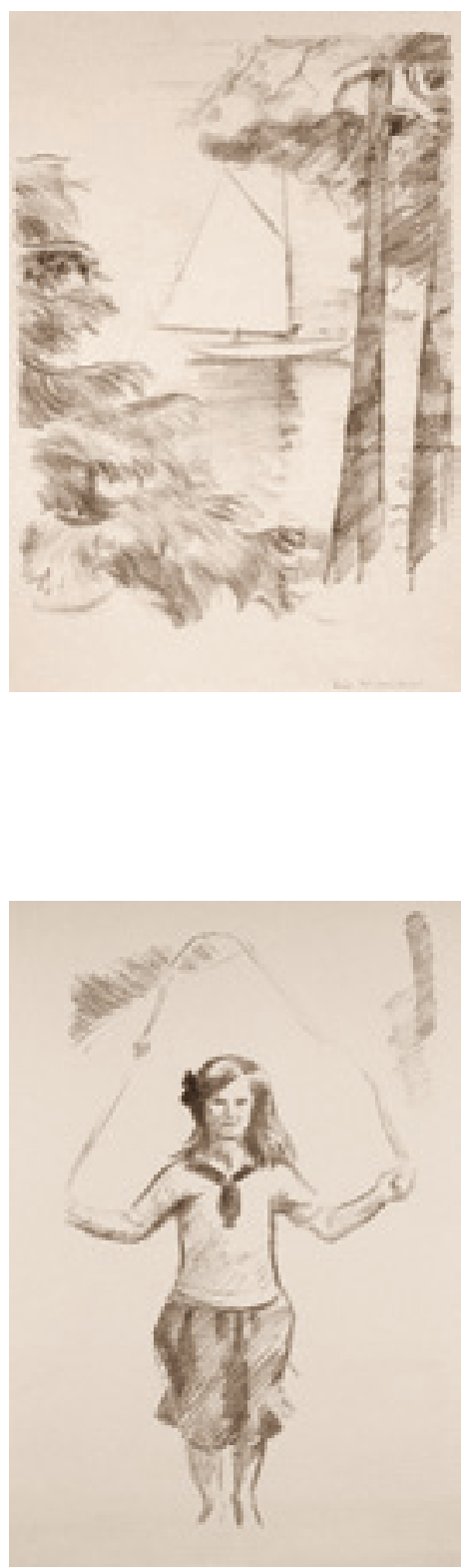
101

ester på havn

1918

EW: Opus 17

Litografi

$275 \times 350 \mathrm{~mm}$

Ingen signatur eller datering $\mathrm{i}$ steinen.

103

Gate i Kongsberg

1918

EW: Opus 19

Litografi

$245 \times 337 \mathrm{~mm}$

Ingen signatur eller datering i steinen.

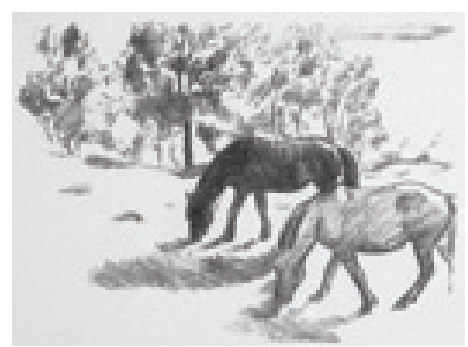

Folungen I

1918

EW: Opus 18

Litografi

$200 \times 375 \mathrm{~mm}$

Ingen signatur eller datering $\mathrm{i}$ steinen.

104

Steinspill

1918

EW: Opus 20

Litografi

$250 \times 365 \mathrm{~mm}$

Ingen signatur eller datering $i$ steinen.
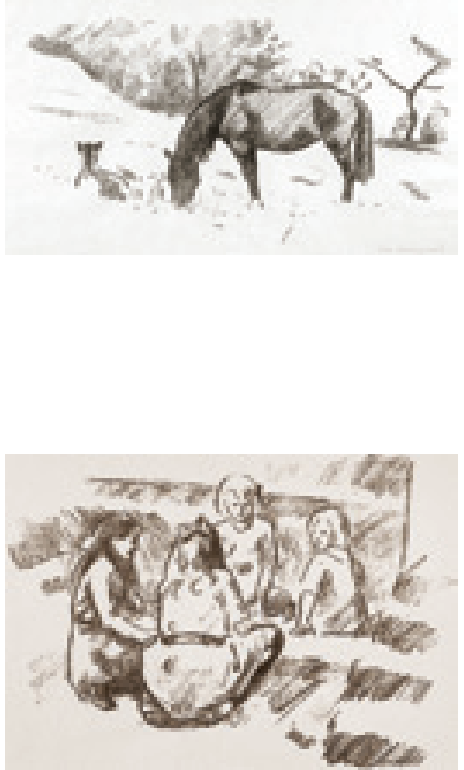


\section{5 \\ Helge Brinchmann}

1918

EW: Opus 21

Litografi

$375 \times 242 \mathrm{~mm}$

Ingen signatur eller datering

steinen.

Helge Brinchmann (1919-1992), sønn av Harald og Ada Concordia

Brinchmann, født Paulsen.

\section{7}

Tulipaner

1918

EW: Opus 23

Litografi

$380 \times 240 \mathrm{~mm}$

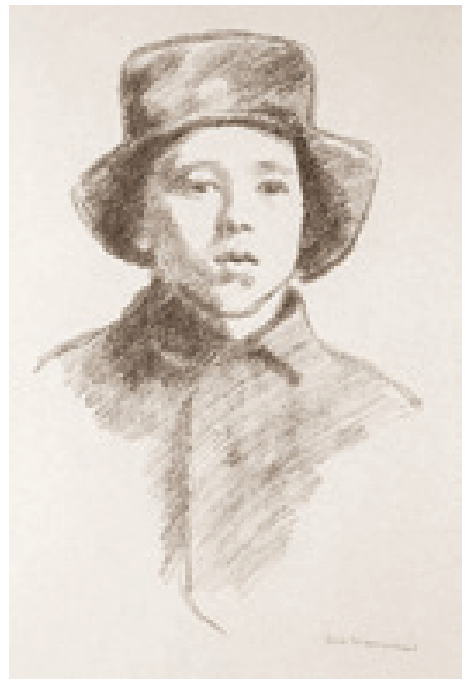

Gate i Kongsberg med asketræ 1918

EW: Opus 22

Litografi

$370 \times 245 \mathrm{~mm}$

Ingen signatur eller datering $\mathrm{i}$

steinen.

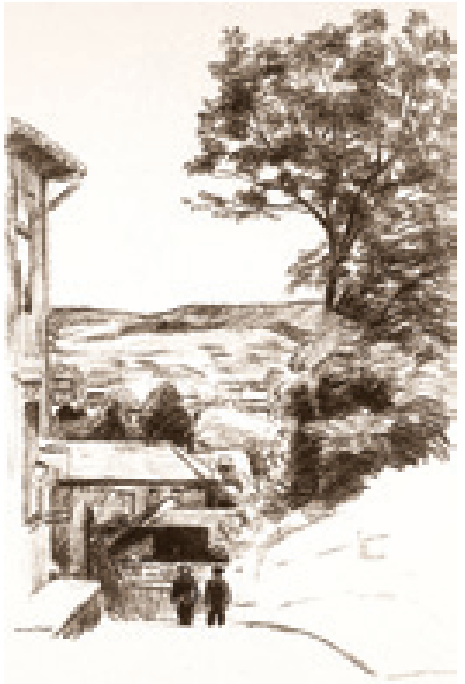

108

\section{Lysakerbrua}

1918

EW: Opus 24

Litografi

$345 \times 510 \mathrm{~mm}$

Ingen signatur eller datering $\mathrm{i}$ steinen.

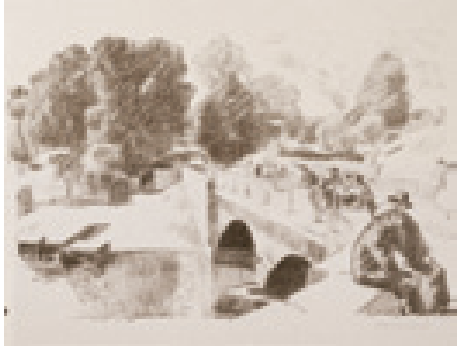


109

Planting

1918

EW: Opus 25

Litografi

$560 \times 435 \mathrm{~mm}$

Ingen signatur eller datering $\mathrm{i}$ steinen.

Vinter

1918

EW: Opus 27

Litografi

$290 \times 430 \mathrm{~mm}$

Ingen signatur eller datering steinen.

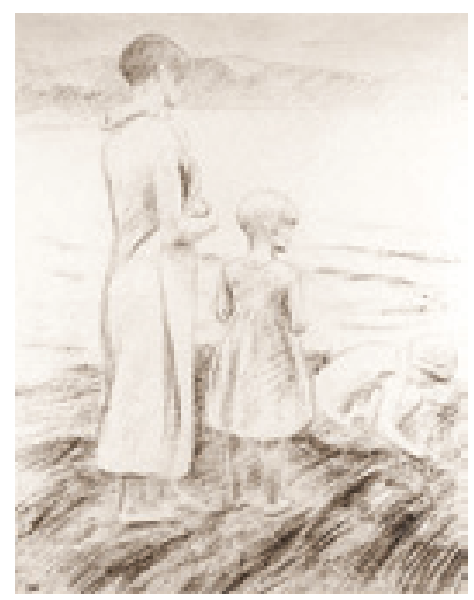

Wergeland på Veslebrunen

1918

EW: Opus 26

Litografi

$265 \times 242 \mathrm{~mm}$

Ingen signatur eller datering $\mathrm{i}$ steinen.

Henrik Wergeland (1808-1845), sønn av Nicolai og Alette

Dorothea Wergeland, født

Thaulow. Bror av Camilla Collett og Oscar Wergeland.
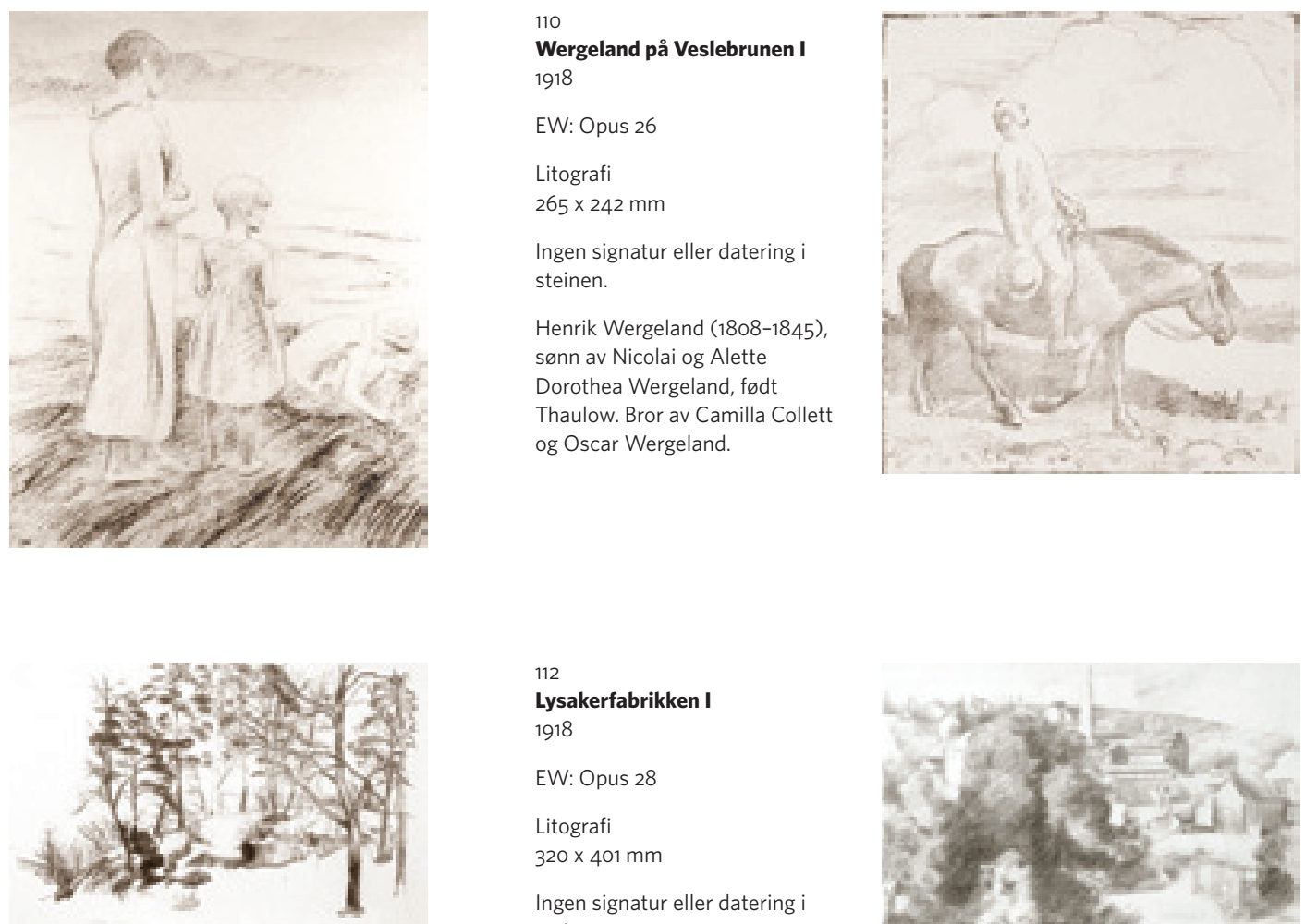

Lysakerfabrikken

1918

EW: Opus 28

Litografi

$320 \times 401 \mathrm{~mm}$

Ingen signatur eller datering steinen.

Litografiet er trykt i to forskjellige farger: svart og brunt.

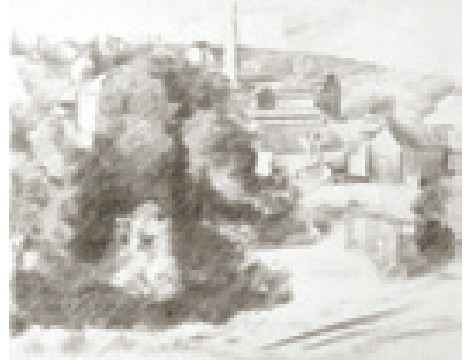


113

Lysakerfabrikken II

1918

EW: Opus 29

Litografi

$320 \times 338 \mathrm{~mm}$

Ingen signatur eller datering steinen.

115

\section{Hund og katt}

1918

EW: Opus 31

Litografi

$300 \times 412 \mathrm{~mm}$

Ingen signatur eller datering steinen.
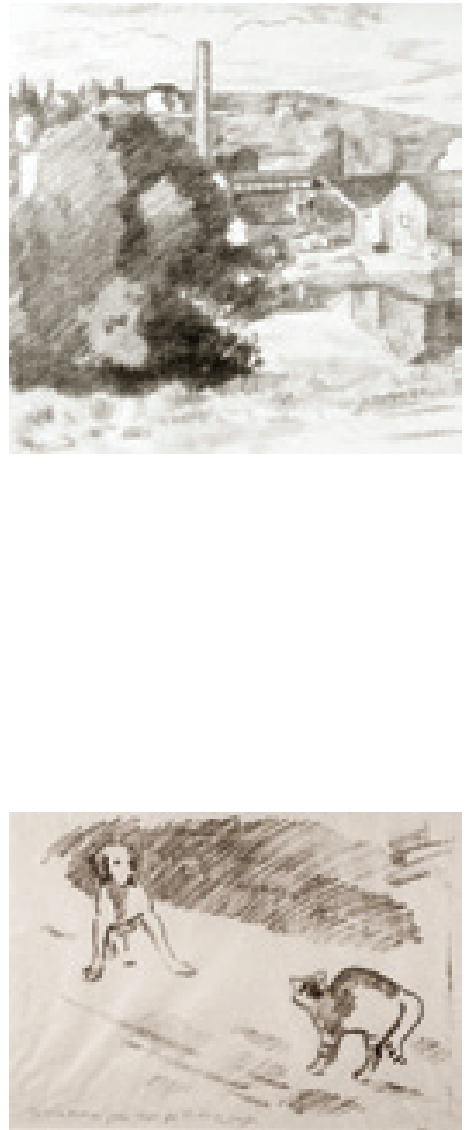

\section{4}

Dr. med. Borchgrevink

1918

EW: Opus 30

Litografi

$300 \times 242 \mathrm{~mm}$

Ingen signatur eller datering i steinen.

Litografiet finnes i to trykkfarger: Svart og brun.

Den portretterte er Otto Johan Borchgrevink (1856-1928), sønn av kaptein Christopher

Weidemann Borchgrevink

og "Alette" Margrethe

Borchgrevink, født Brodtkorb.

Otto Borchgrevink ble ridder av

St. Olavs Orden iapril 1928, for sin samfunnsgagnlig tjeneste.

116

\section{Skybanken}

1918

EW: Opus 32

Litografi

$248 \times 325 \mathrm{~mm}$

Ingen signatur eller datering $\mathrm{i}$ steinen.
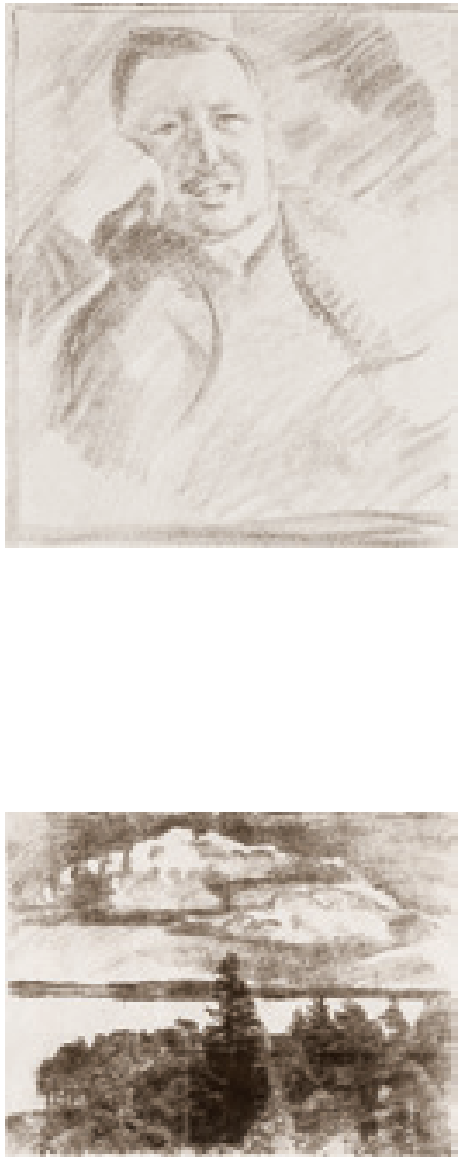
117

På verandaen

1918

EW: Opus 33

Litografi

$374 \times 252 \mathrm{~mm}$

Ingen signatur eller datering steinen.

Litografiet finnes i to trykkfarger: svart og brun.

Kvinnen på verandaen er Anne Poulsson (1885-1955), født Bache-Wiig, gift med arkitekt

Magnus Poulsson.
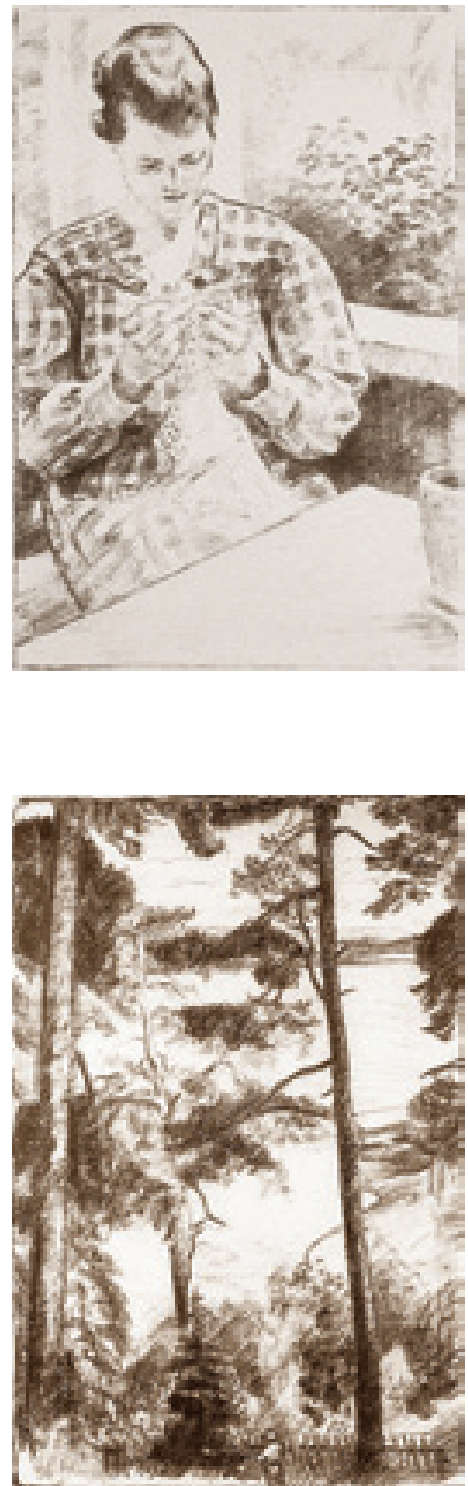

Fru

EW: Opus 34

Litografi

$365 \times 245 \mathrm{~mm}$

Ingen signatur eller datering i steinen.

Anne Poulsson (1885-1955), fød Bache-Wiig, gift med arkitekt

Magnus Poulsson.

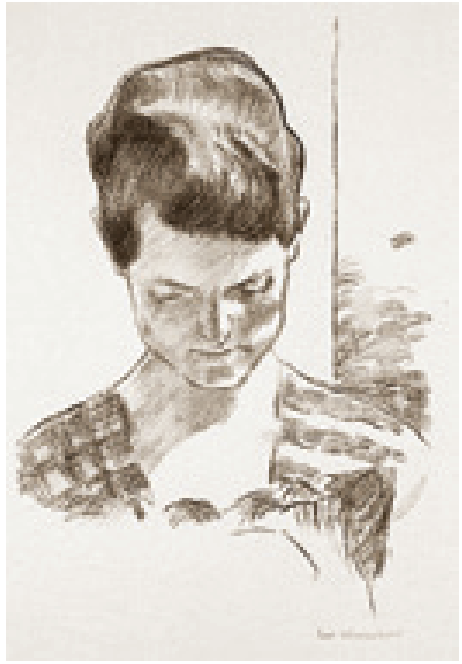

Konsul Heiberg

1918

EW: Opus 45

Litografi

$727 \times 544 \mathrm{~mm}$

Ingen signatur eller datering steinen.

Litografiet ble laget til

20-årsmarkeringen for Det norske skogselskap. Axel Heiberg var Skogselskapets stifter 26.9. 1898.

Litografiet finnes både med og uten påskrift. Påskrift: "Erik Werenskiold//Axel Heiberg//Det norske skogselskaps//stifter//

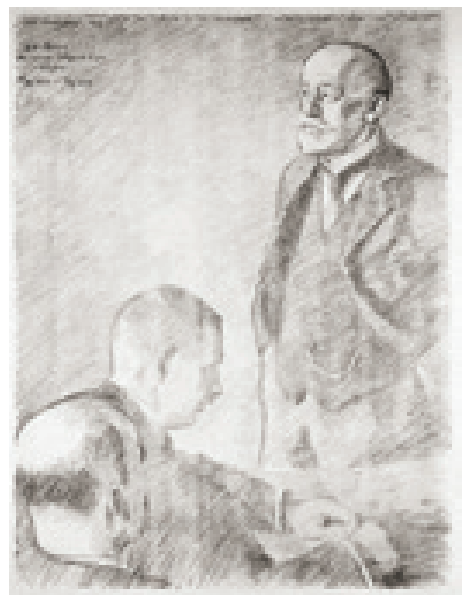
26/9 1898 - 26/9 1918/ 
Seileren

1919

EW: Opus 36

Litografi

$325 \times 245 \mathrm{~mm}$

Ingen signatur eller datering steinen.

123

\section{Gutteflokk}

1919

EW: Opus 38

Litografi

$255 \times 327 \mathrm{~mm}$

Ingen signatur eller datering i steinen.

\section{2}

To fabrikkpiper

1919

EW: Opus 37

Litografi
Bildet er ikke å oppdrive

\section{4}

iten gutt i gyngestol

1919

EW: Opus 39

Litografi

$260 \times 340 \mathrm{~mm}$
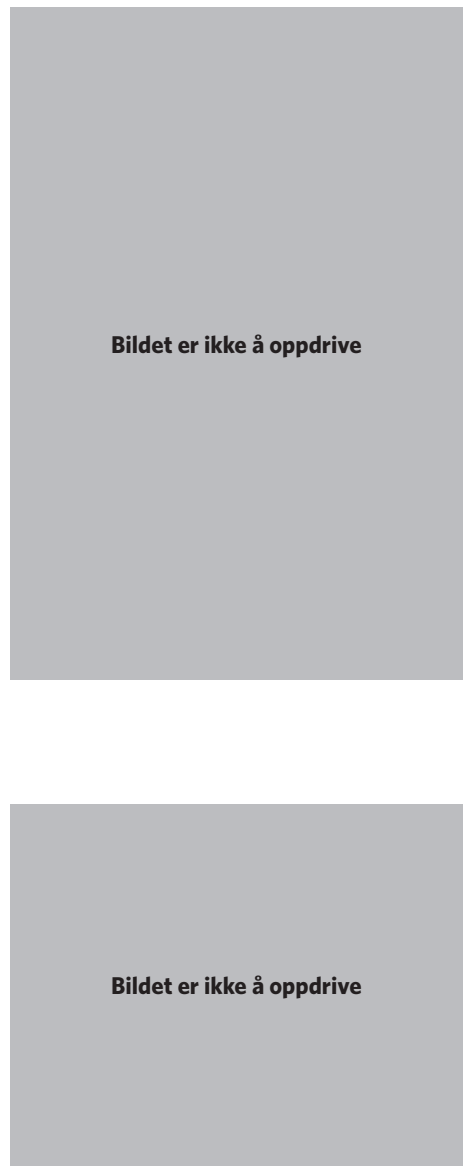
125

Werner Werenskiold

1919

EW: Opus 51

Litografi

$335 \times 245 \mathrm{~mm}$

Ingen signatur eller datering $\mathrm{i}$ steinen.

Werner Werenskiold (1885-1963), Erik Werenskiolds nevø, var generalkonsul i Wien. Han ble tildelt Kommandørkorset av St Olavs Orden og

St. Olavsmedaljen for utbredelse av kjennskap om Norge i

Østerrike.

\section{7}

\section{Dagfin leser avisen}

1919?

EW: Opus 82

Litografi

$330 \times 250 \mathrm{~mm}$

Ingen signatur eller datering i steinen.

Dagfin Werenskiold (1892-1977), kunstner og sønn av Erik og Sophie Marie Werenskiold, født Stoltenberg Thomesen. Dagfin var gift med Elisabeth ("Beth") Mathilde, født Schram (1897-1989).

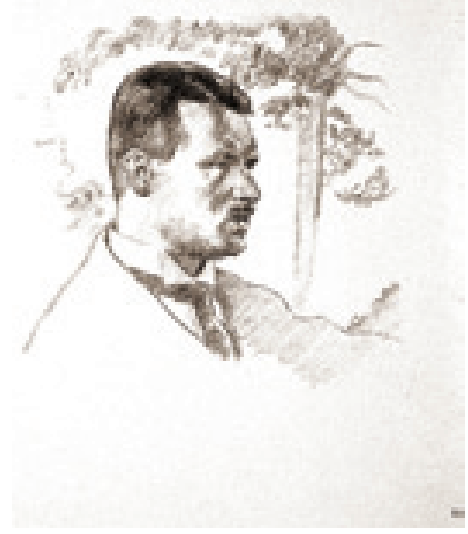

126

Asketre med fabrikk

1919?

EW: Opus 40

Litografi

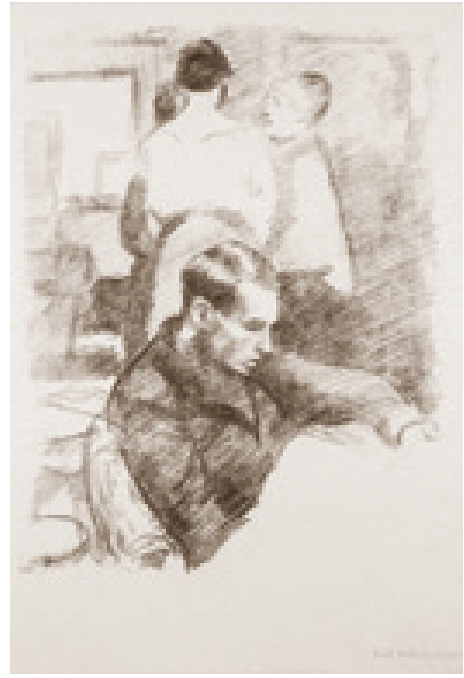

Jens Erik, Tone og Bebe med ringbanen

1920 ?

EW: Opus 83

Litografi

$240 \times 410 \mathrm{~mm}$

Ingen signatur eller datering i steinen.

De tre er som er avbildet, er Erik Werenskiolds barnebarn. "Bebe" heter egentlig Sophie Marie.
Bildet er ikke å oppdrive
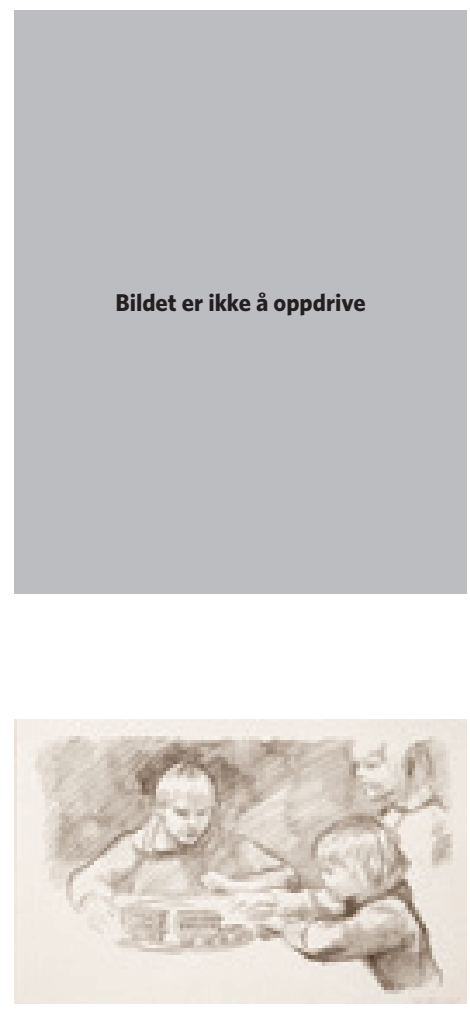
129

Fjord bak bjørkene

1920

EW: Opus 41

Litografi

$382 \times 455 \mathrm{~mm}$

Ingen signatur eller datering i steinen.

\section{1 \\ Vi er på ball \\ 1920}

EW: Opus 69

Streketsning

$248 \times 322 \mathrm{~mm}$

Signert i platen n.t.v.: EW

“Ornamentikken betyr valsetakten [i] Hoffmanns eventyr", ifølge Werenskiolds notater.

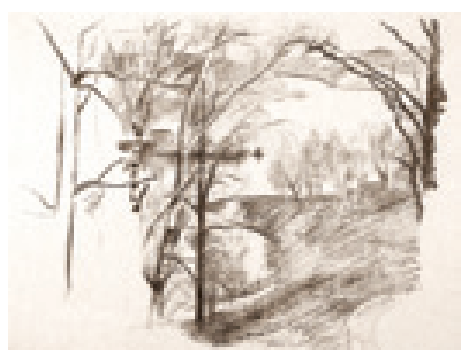

130

Danserinne

1920

EW: Opus 42

Litografi

$460 \times 300 \mathrm{~mm}$

Ingen signatur eller datering i steinen.

Litografiet har også tittelen Ge i dansedrakt ifølge Werenskiolds notater.

132

Unghesten

1920

EW: Opus 43

Litografi

$404 \times 518 \mathrm{~mm}$

Ingen signatur eller datering i steinen.
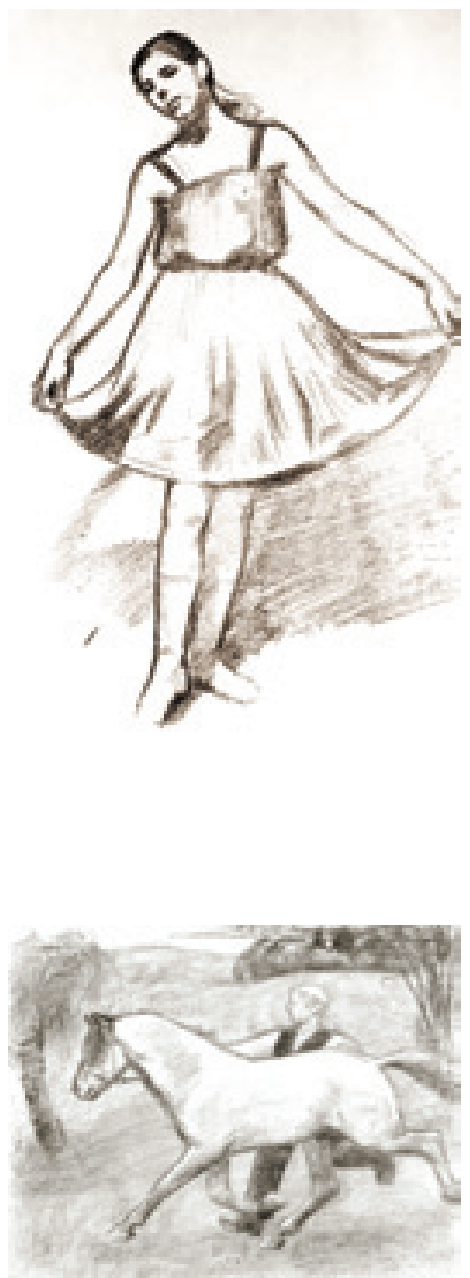


\section{3 \\ Dagfin I}

1920

EW: Opus 44

Litografi

$416 \times 318 \mathrm{~mm}$

Ingen signatur eller datering steinen.

Dagfin Werenskiold (1892-1977), kunstner og sønn av Erik og

Sophie Marie Werenskiold, født Stoltenberg Thomesen. Dagfin var gift med Elisabeth ("Beth")

Mathilde, født Schram

(1897-1989).

\section{5}

\section{Nordahl Rolfsen}

1920

EW: Opus 47

Litografi

$375 \times 314 \mathrm{~mm}$

Ingen signatur eller datering i steinen.

Johan Nordahl Rolfsen

(1848-1928) utga en rekke

lærebøker for barn. Hans største

verk var Lesebok for folkeskolen

(1892-1895), som i flere reviderte

utgaver ble den mest utbredte

skolebok i Norge. Boken var rikt illustrert av norske kunstnere,

blant dem Erik Werenskiold.

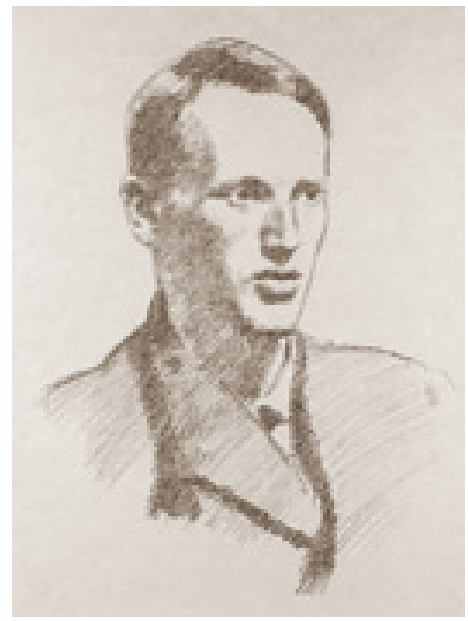

134

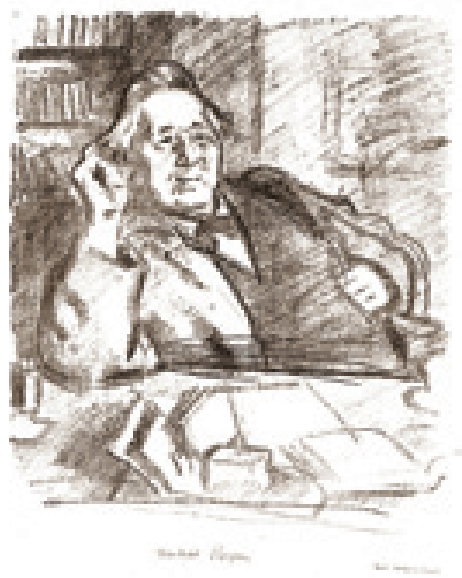

Hans Aal

1920

EW: Opus 46

Litografi

$265 \times 205 \mathrm{~mm}$

Ingen signatur eller datering i steinen.

Hans Jacob Aall (1869-1946) va Norsk Folkemuseums

grunnlegger. Litografiet ble laget som takk fra museets styre til Hans Aall for 25 års virke. Trykket finnes både med og uten trykt påskrift. Påskriften er: "Til/ Norsk Folkemuseums Grundlegger/

Direktør Hans Aall/ fra Museets Styre med Tak og Beundring/ for 25 Aars Virke// Mai 1920/"

136

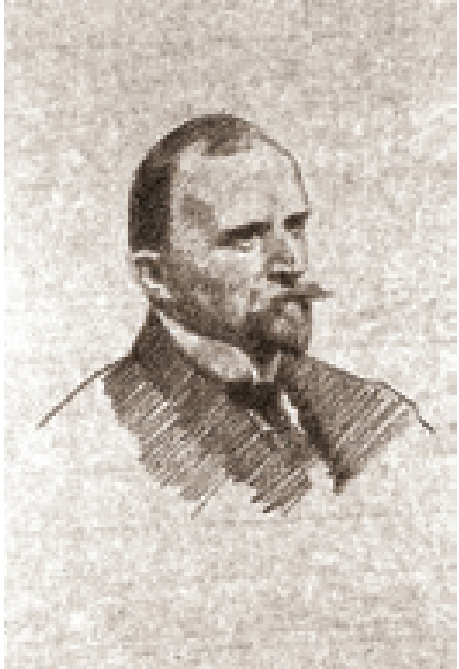

Henrik Sørensen og Jean

Heiberg I

1920

EW: Opus 48

Litografi

$360 \times 450 \mathrm{~mm}$

Ingen signatur eller datering i steinen.

Henrik Sørensen (1882-1962) var en markant kunstner og

samfunnsdebattant. Jean Heiberg (1884-1976) bidro sterkt til modernismens gjennombrudd i

Norge som professor ved Statens Kunstakademi i perioden 1935-1955. Sørensen og Heiberg ble Werenskiolds venner og støttespillere i kunstpolitikken. Dehadde en felles begeistring forPaul Cézannes kunst.

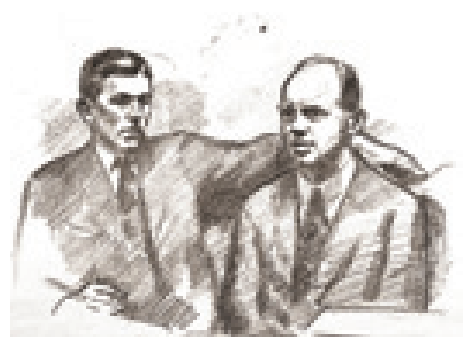


137

Henrik Sørensen og Jean Heiberg II

1920

EW: Opus 49

Litografi

$468 \times 590 \mathrm{~mm}$

Ingen signatur eller datering i steinen.

Henrik Sørensen (1882-1962) var en markant kunstner og

samfunnsdebattant. Jean Heiberg (1884-1976) bidro sterkt til

modernismens gjennombrudd $i$

Norge som professor ved Statens

Kunstakademi i perioden

1935-1955. Sørensen og Heiberg

ble Werenskiolds venner og

støttespillere i kunstpolitikken. De

hadde en felles begeistring for

Paul Cézannes kunst.

\section{9}

Thorvald Erichsen II

1920

EW: Opus 70

Litografi

$415 \times 480 \mathrm{~mm}$

Ingen signatur eller datering i steinen.

Thorvald Erichsen (1868-1939), kunstner og venn av Erik

Werenskiold. Erichsen var Werenskiolds elev i 1891.

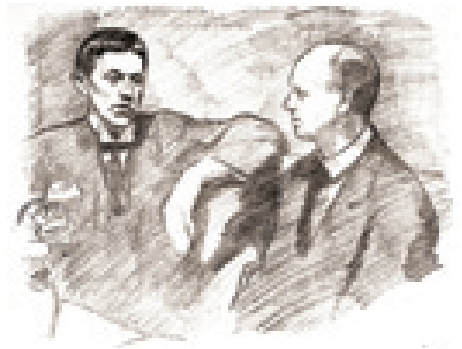

138

\section{Thorvald Erichsen I}

1920

EW: Opus 50

Litografi

$440 \times 465 \mathrm{~mm}$

Ingen signatur eller datering i steinen.

Thorvald Erichsen (1868-1939), kunstner og venn av Erik

Werenskiold. Erichsen var Werenskiolds elev i 1891.

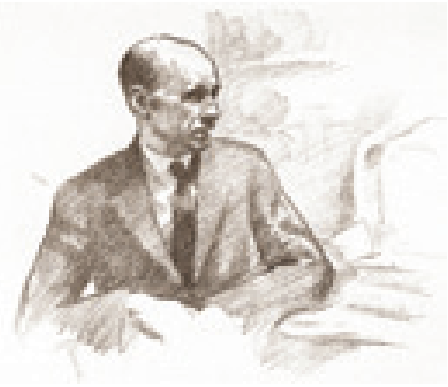

140

Thorvald Erichsen III

1920

EW: Opus 145

Litografi

$450 \times 560 \mathrm{~mm}$

Ingen signatur eller datering i steinen.

Thorvald Erichsen (1868-1939), kunstner og venn av Erik

Werenskiold. Erichsen var Werenskiolds elev i 1891.
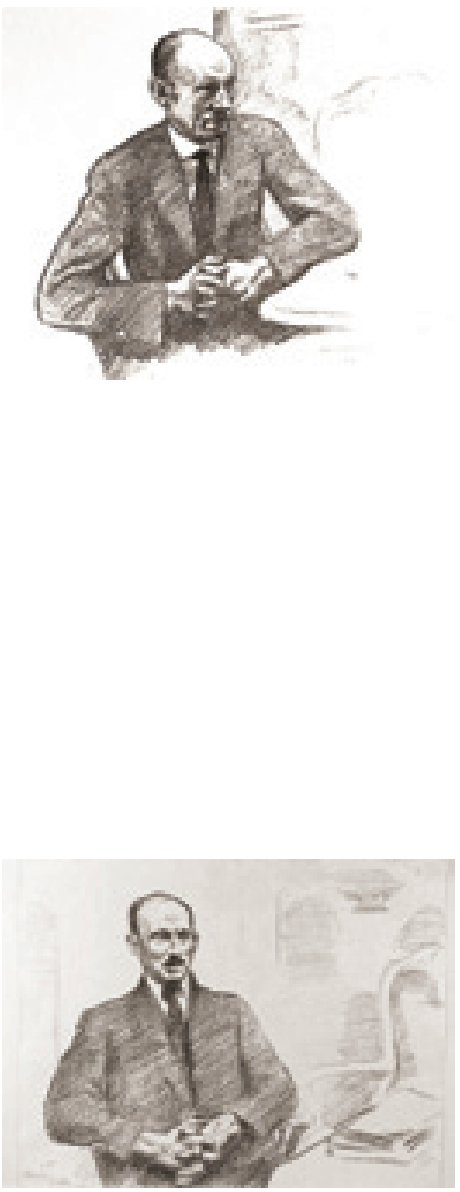
141

Sigrid og Bebe

1920

EW: Opus 52

Litografi

$290 \times 240 \mathrm{~mm}$

Ingen signatur eller datering i steinen.

"Bebe" het egentlig Sophie Marie og var Erik Werenskiolds barnebarn.

143

De to som danser

1920

EW: Opus 54

Litografi

$420 \times 510 \mathrm{~mm}$

Ingen signatur eller datering i steinen.

De to pikene som danser, er Eva og Else Carlsen.
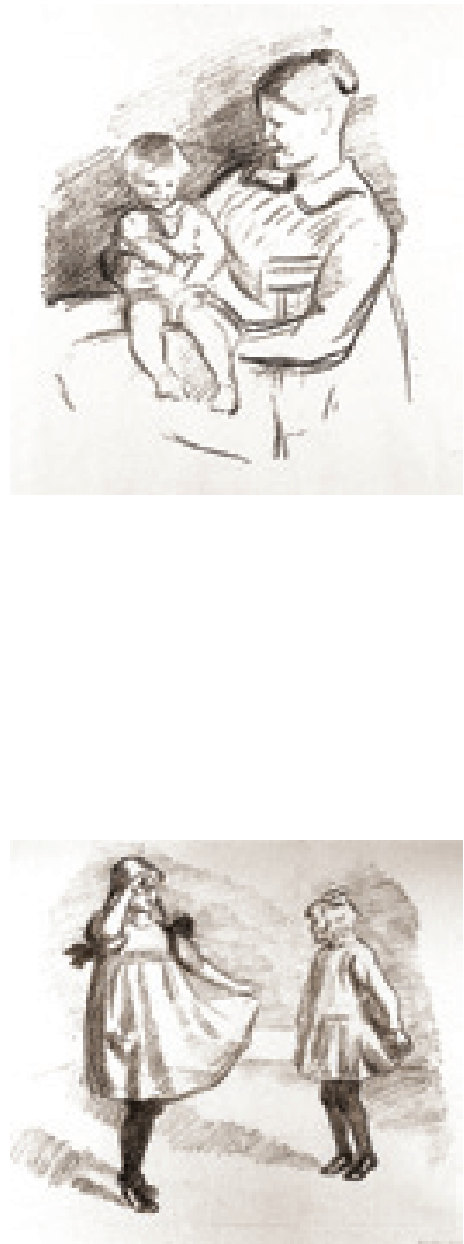

42

Lindetrær og graner

1920

EW: Opus 53

Litografi

$410 \times 250 \mathrm{~mm}$

Ingen signatur eller datering i steinen.

144

De tre som valser

1920

EW: Opus 55

Litografi

$440 \times 600 \mathrm{~mm}$

Ingen signatur eller datering $\mathrm{i}$ steinen.

De tre pikene er Mäbel Wulfsberg
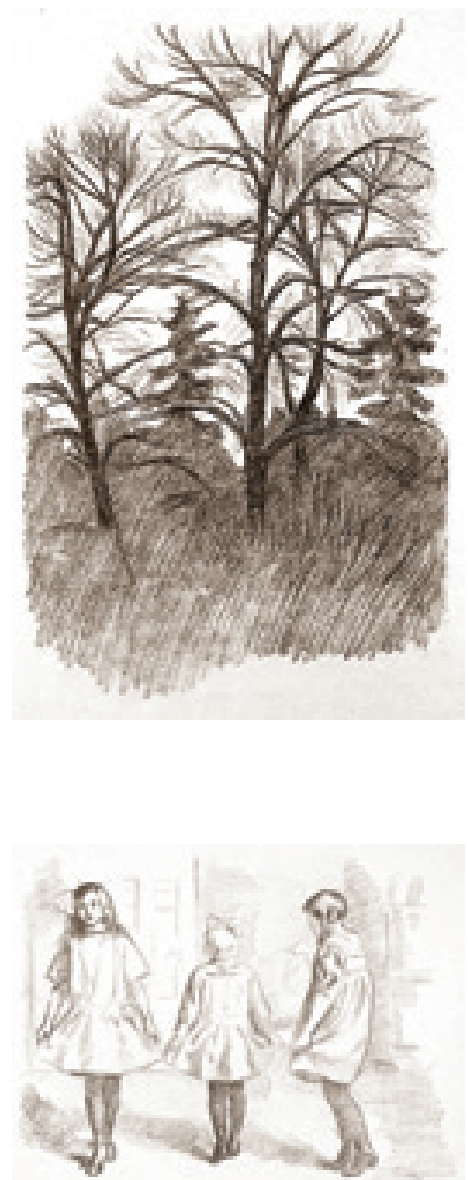

og Eva og Else Carlsen. 
145

1920

EW: Opus 56

Litografi

$560 \times 468 \mathrm{~mm}$

Ingen signatur eller datering steinen.

De to pikene er Eva og Else

Carlsen.

\section{7 \\ Nils Collett Vogt}

1920

EW: Opus 58

Litografi

$525 \times 427 \mathrm{~mm}$

Ingen signatur eller datering $\mathrm{i}$ steinen.

Nils Collett Vogt (1864-1937) debuterte som forfatter i 1887 . Sønn av Jens Theodor og Johanne Christiane Vogt, født Collett.

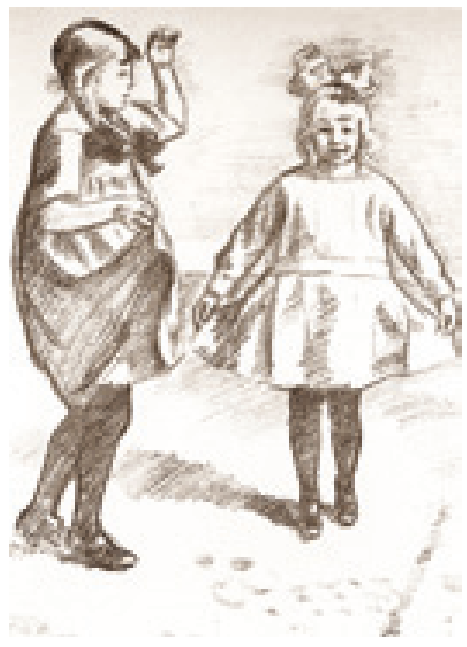

146

En prat

1920

EW: Opus 57

Litografi

$588 \times 430 \mathrm{~mm}$

Ingen signatur eller datering $\mathrm{i}$ steinen

To av pikene (med sløyfer i håret) er Mäbel og Anabel Wulfsberg.

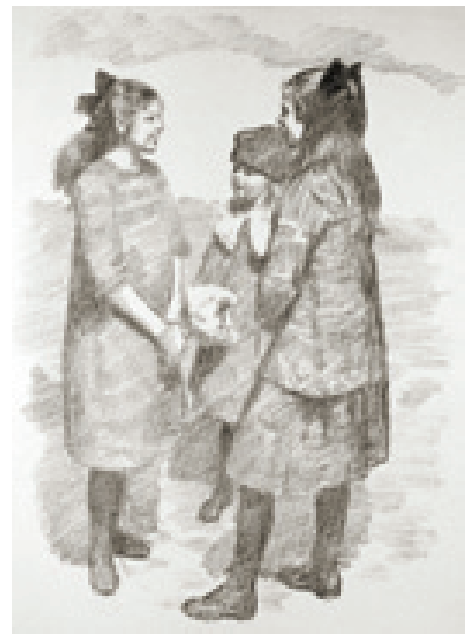

148

Bruene

1920

EW: Opus 59

Litografi

$300 \times 470 \mathrm{~mm}$

Ingen signatur eller datering i steinen.

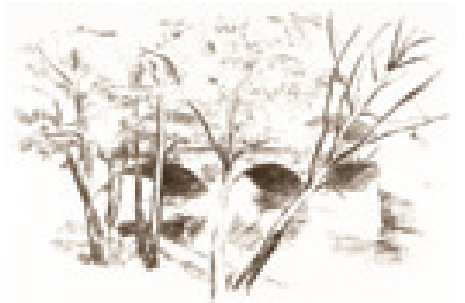


149

Hans E. Kinck II

1920

EW: Opus 60

Litografi

$515 \times 455 \mathrm{~mm}$

Ingen signatur eller datering steinen.

Hans Ernst Kinck (1865-1926) var romanforfatter, dramatiker, lyriker og en allsidig essayist.

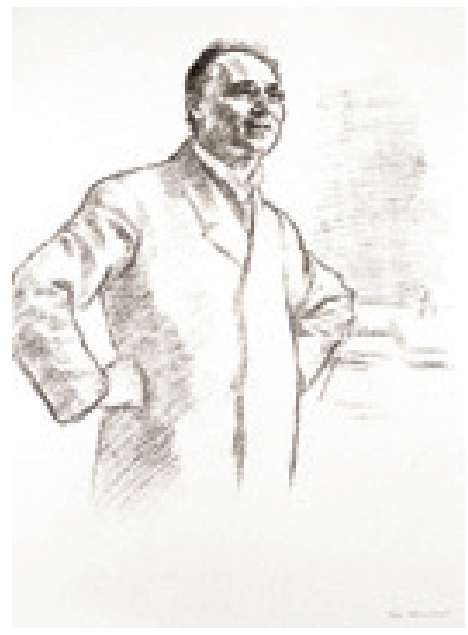

50

Hans E. Kinck III

1920

EW: Opus 61

Litografi

$460 \times 570 \mathrm{~mm}$

Ingen signatur eller datering i steinen.

Hans Ernst Kinck (1865-1926) var romanforfatter, dramatiker, lyriker og en allsidig essayist.

152

\section{Kusine}

1920

EW: Opus 63

Litografi

$520 \times 360 \mathrm{~mm}$

Ingen signatur eller datering i steinen.
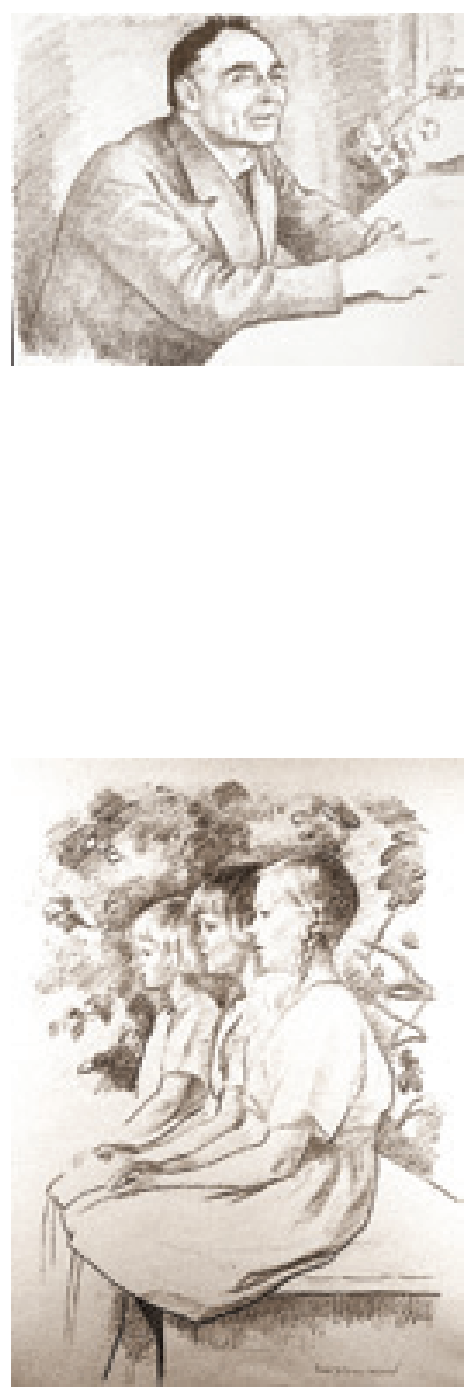
153

\section{Fridtjof Nansen I}

1920

EW: Opus 64

Litografi

$450 \times 370 \mathrm{~mm}$

Ingen signatur eller datering i steinen.

Fridtjof Nansen (1861-1930) var Erik Werenskiolds nære venn og nabo på Lysaker.

155

\section{Sophie og Vir}

1920

EW: Opus 66

Litografi

$418 \times 470 \mathrm{~mm}$

Ingen signatur eller datering i steinen.

De to er Sophie Marie

Werenskiold, født Stoltenberg Thomesen (1849-1926), gift med

Erik Werenskiold, og Virginia

Mathilde Schjelderup, født

Thomesen (1855-1943). Sophie

og Vir er søstre.

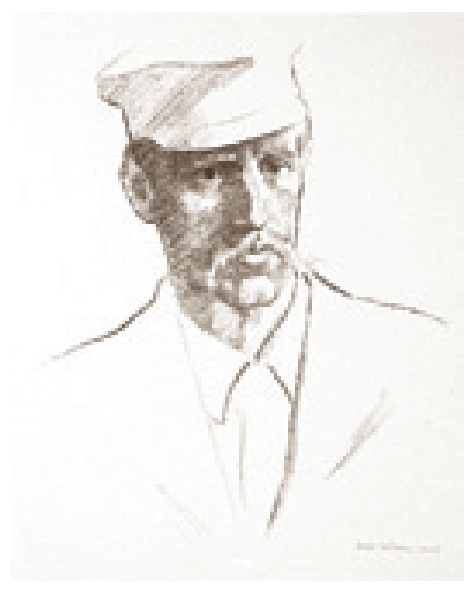

154

\section{Jørgen og Vir}

1920

EW: Opus 65

Litografi

$460 \times 580 \mathrm{~mm}$

Ingen signatur eller datering $\mathrm{i}$ steinen.

De portretterte er av konsul Jørgen Lysholm Schjelderup (1852-1928) og Virginia Mathilde

Schjelderup, født Thomesen

(1855-1943), Sophie

Werenskiolds søster.

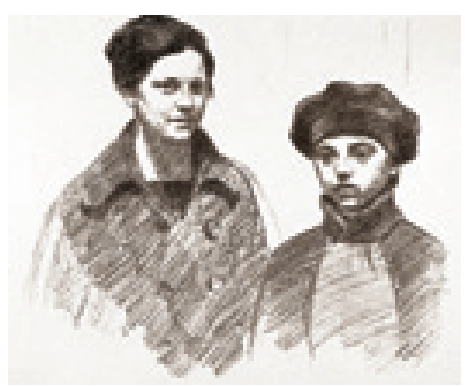

156

\section{Mor leker fremmed dame}

1920

EW: Opus 67

Litografi

$533 \times 408 \mathrm{~mm}$

Ingen signatur eller datering $\mathrm{i}$ steinen.

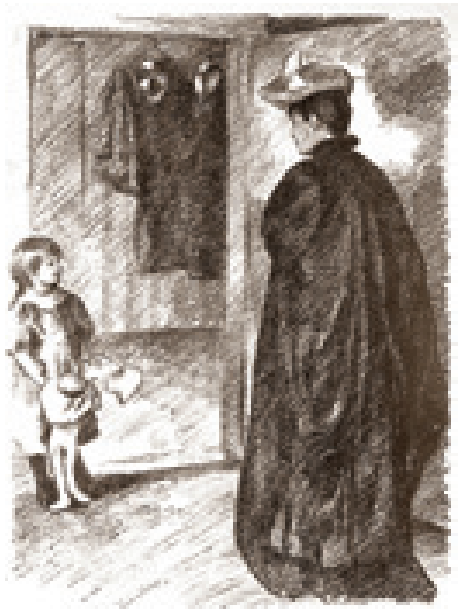


157

\section{En røyk}

1921

EW: Opus 68

Litografi

$450 \times 320 \mathrm{~mm}$

Ingen signatur eller datering i steinen.

Litografiets tittel har tilføyelsen "Torstensen. Arbeider" i

Werenskiolds notater. I brev til Bernt Grønvold i Berlin datert 27 3. 1921 skriver Werenskiold at mannen er en "sambygding" fra Eidskogen.

159

To på en stol

1921

EW: Opus 69

Litografi

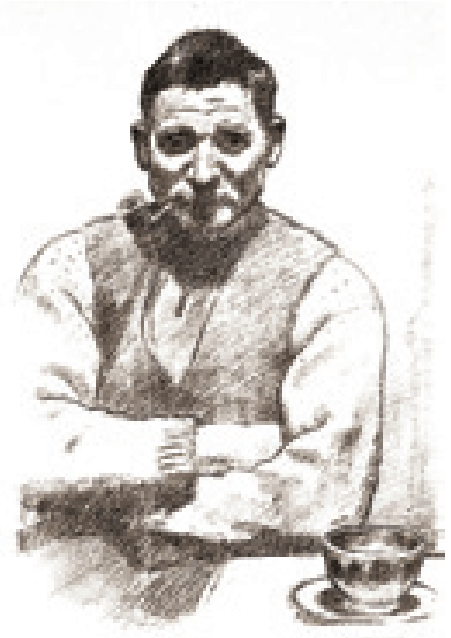

158

Schanche som Hamlet

1921?

EW: Uten opusnumme

\section{Litografi}

Dateringen er omtrentlig og

begrunnet ut fra følgende:

I 1921 spilte Ingolf Schanche

(1871-1954) rollen som Hamlet på

Nationaltheatret første gang.

Et oljemaleri med samme titte

ble utført av Werenskiold i 1926.

160

Baskens Ex libris. Reinblom

1921

EW: Opus 71

Litografi

"Basken" (1884-1952) het egentlig Karen Inga, datter av Erik og

Sophie Werenskiold.
Bildet er ikke å oppdrive
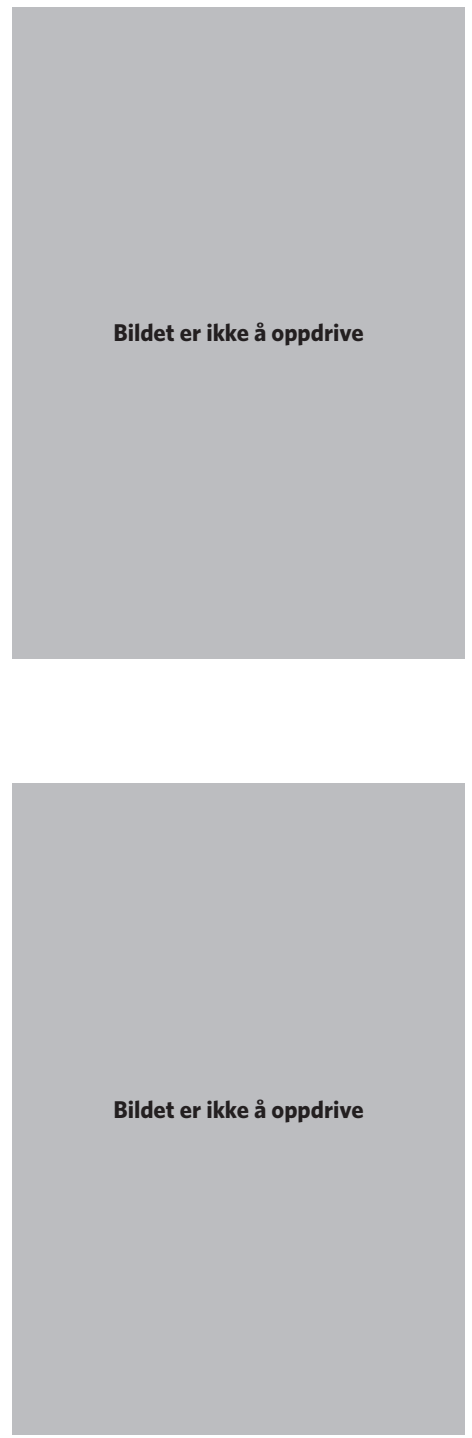
161

Professor Schiøtz

1921

EW: Opus 72

Litografi

Dette kan være et portrett av lege og professor Carl Schiøtz (1877-1938)?

163

Ut på ski

1921

EW: Opus 74

Litografi

$205 \times 400 \mathrm{~mm}$

Ingen signatur eller datering i steinen.

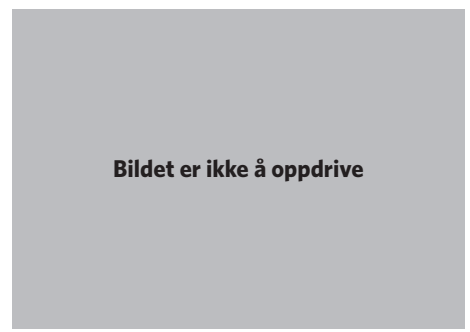

\section{Odd Nansen}

1921

EW: Opus 73

Litografi

$234 \times 330 \mathrm{~mm}$

Ingen signatur eller datering $\mathrm{i}$ steinen.

Odd Nansen (1901-1973) var arkitekt og sønn av Fridtjof og Eva Helene Nansen, født Sars.

164

Store tordenskyer

1921

EW: Opus 75

Litografi

Ingen signatur eller datering i steinen.
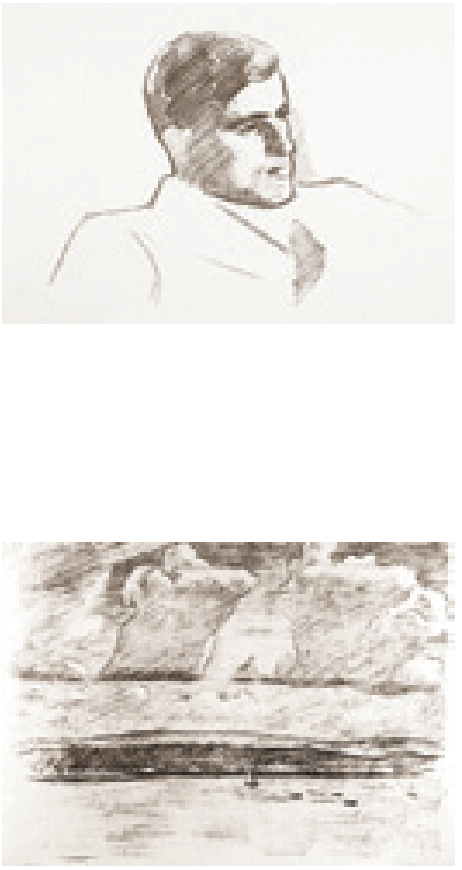
165

Tordenskyer

1921

EW: Opus 76

Litografi

$445 \times 536 \mathrm{~mm}$

Ingen signatur eller datering i steinen.

167

Kaptein Otto Sverdrup

1921

EW: Opus 78

Litografi

$320 \times 270 \mathrm{~mm}$

Ingen signatur eller datering $\mathrm{i}$ steinen.

Otto Sverdrup (1854-1930) var norsk polarforsker. I 1888 deltok han på Fridtjof Nansens

Grønlandsekspedisjon.

Han var også med på den første Fram-ferden mot Nordpolen 1893-1896.

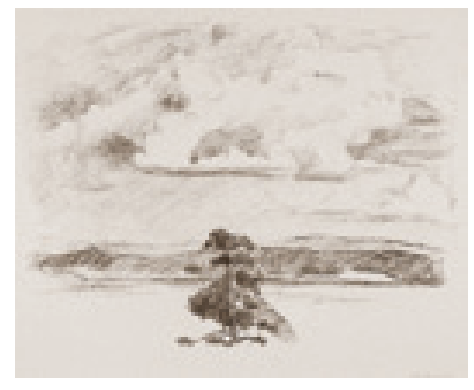

Kari

1921

EW: Opus 77

Litografi

$232 \times 223 \mathrm{~mm}$

Ingen signatur eller datering i steinen.

Kari er Erik Werenskiolds

barnebarn, Dagfin og Beth Werenskiolds datter.

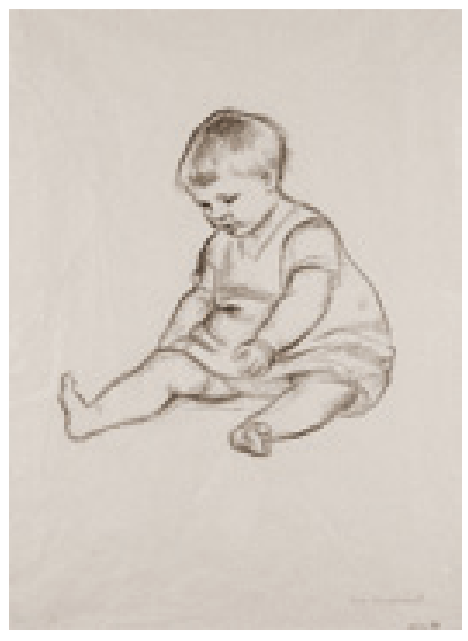

168

Eplekvist

1921

EW: Opus 81

Litografi

$192 \times 210 \mathrm{~mm}$

Ingen signatur eller datering i steinen.

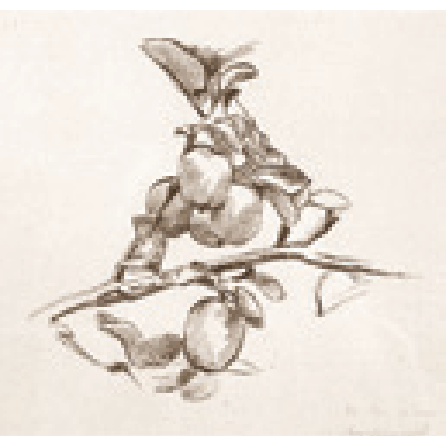


169

Revolusjonen

1921?

EW: Opus 152b

Litografi

$373 \times 561 \mathrm{~mm}$

Ingen signatur eller datering $\mathrm{i}$

steinen.

Dette litografiet kan ha vært stilt ut i Kunstnerforbundet i mars

1922 under tittelen Blodtørst. Det samme motivet er også funnet med tittelen Hungersnød. I katalog til "Minneutstilling, sort og hvitt", 1940, forekommer tittelen Rottene gnager lik.

I brev til Bernt Grønvold datert 18.12. 1920, skriver Erik

Werenskiold om situasjonen

Russland, med hungersnød og

fortvilelse, noe som kan ha ført til

at han laget dette litografiet.

\section{1 \\ Hest og føll}

1921

EW: Opus 80

Litografi

$200 \times 380 \mathrm{~mm}$

Ingen signatur eller datering i steinen.

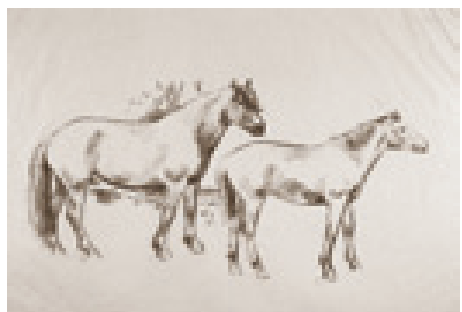

Motivet er fra Eidsvoll.

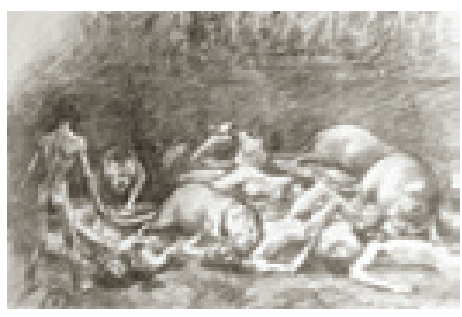

170

bjørketrær på en haug

1921

EW: Opus 79

Litografi

$400 \times 290 \mathrm{~mm}$

Ingen signatur eller datering $\mathrm{i}$ steinen.

Motivet er fra Eidsvoll.

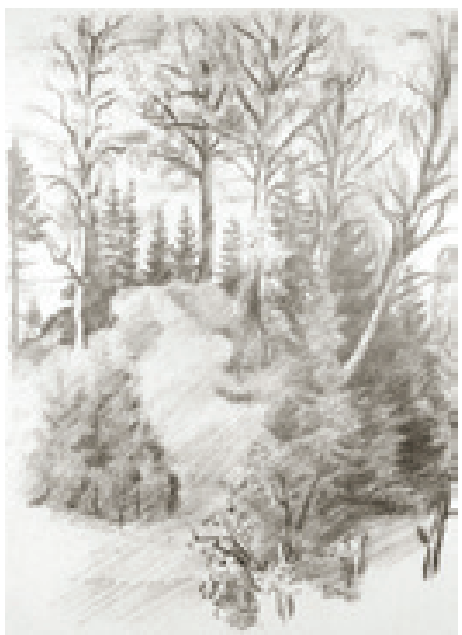

172

\section{Schnéevoigt dirigerer}

1922

EW: Opus 84

Sinkografi (litografi på sinkplate) $370 \times 400 \mathrm{~mm}$

Ingen signatur eller datering $\mathrm{i}$ platen.

Den finske cellisten og dirigenten Georg Lennart Schnéevoigt (1872-1947) var med på dannelsen av Filharmonisk Selskaps Orkester i Oslo i 1919, og var førstedirigent der til 1927.

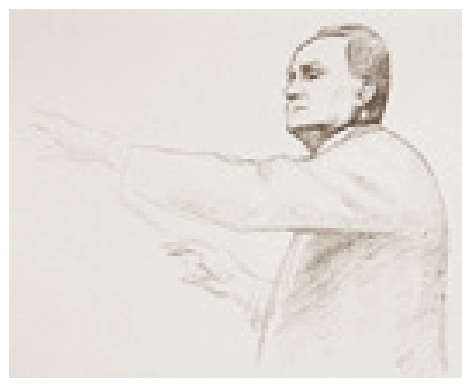


173

Schnéevoigt

1922

EW: Opus 85

Sinkografi (litografi på sinkplate) $600 \times 400 \mathrm{~mm}$

Ingen signatur eller datering platen.

Den finske cellisten og dirigenten Georg Lennart Schnéevoigt

(1872-1947) var med på

dannelsen av Filharmonisk

Selskaps Orkester i Oslo i 1919, og var førstedirigent der til 1927.

\section{En alvorlig samtale}

1922

EW: Opus 87

Sinkografi (litografi på sinkplate) $390 \times 510 \mathrm{~mm}$

Ingen signatur eller datering platen.
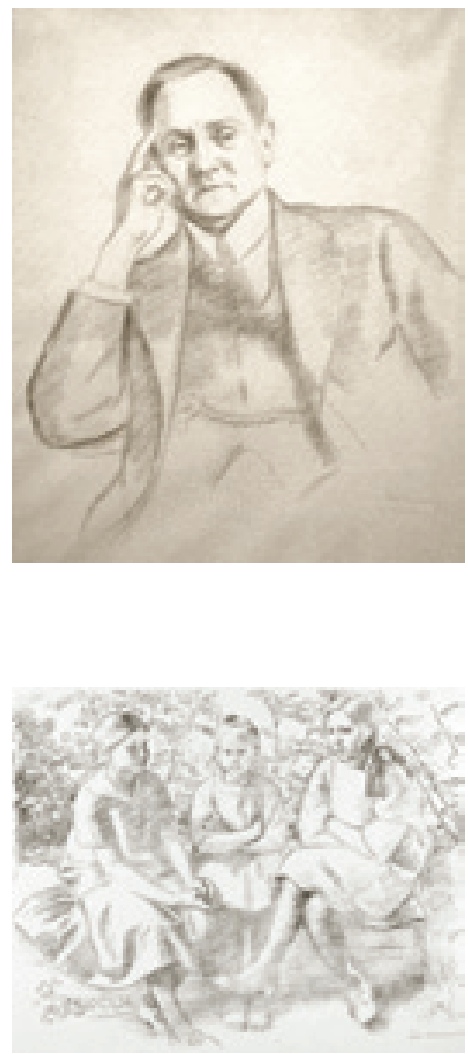

174

\section{Boken}

1922

EW: Opus 86

Sinkografi (litografi på sinkplate) $281 \times 338 \mathrm{~mm}$

Ingen signatur eller datering i platen.

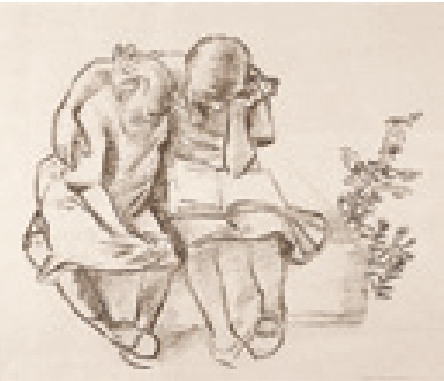

176

\section{Tone og Bebe}

1922

EW: Opus 88

Sinkografi (litografi på sinkplate) $462 \times 362 \mathrm{~mm}$

Ingen signatur eller datering $\mathrm{i}$ platen.

Tone og Bebe er Erik

Werenskiolds barnebarn. "Bebe" het egentlig Sophie Marie.

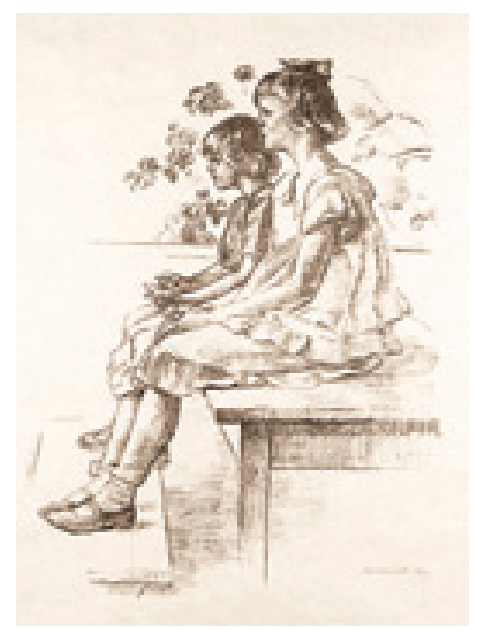


177

1922

EW: Uten opusnummer

Litografi

$405 \times 510 \mathrm{~mm}$

Ingen signatur eller datering steinen.

"Bebe" het egentlig Sophie Marie og er Erik Werenskiolds

barnebarn. Lisbeth er arkitekt

Arnstein Arnebergs datter.

179

Huldra I

1924

EW: Opus 90

Litografi

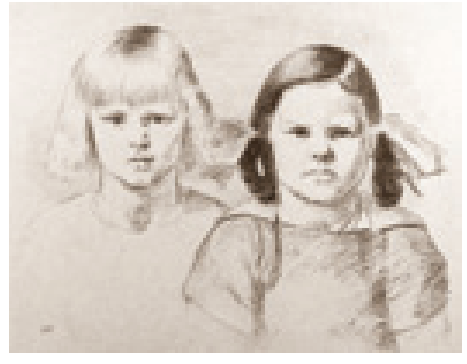

178

Trappen

1922

EW: Opus 89

Litografi

$335 \times 320 \mathrm{~mm}$

Ingen signatur eller datering i

steinen.

Fridtjof Nansen II

1924

EW: Opus 91

Litografi

$515 \times 398 \mathrm{~mm}$

Ingen signatur eller datering $\mathrm{i}$

steinen.

Fridtjof Nansen (1861-1930) var Erik Werenskiolds nære venn og nabo på Lysaker.
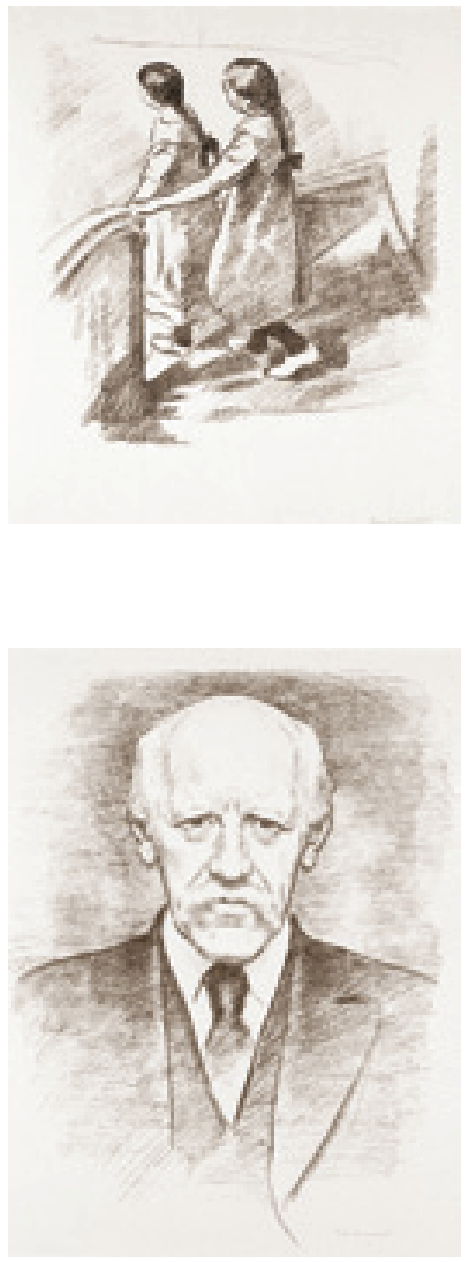
Motgang

1925

EW: Opus 92

Litografi

$420 \times 460 \mathrm{~mm}$

Ingen signatur eller datering i

steinen.

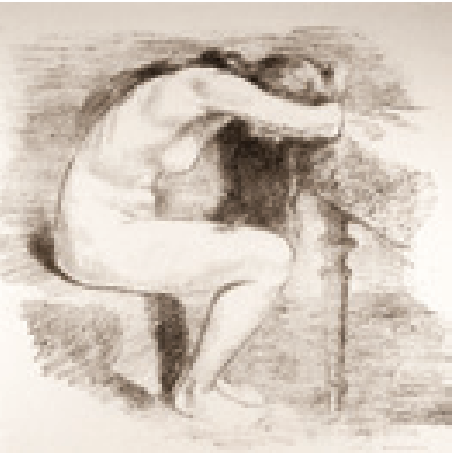

Fru Østby

1925

EW: Opus 93

Litografi

Landskap fra Kviteseid

1925

EW: Opus 94

Litografi

$405 \times 535 \mathrm{~mm}$

Ingen signatur eller datering $i$

steinen.
Bildet er ikke å oppdrive
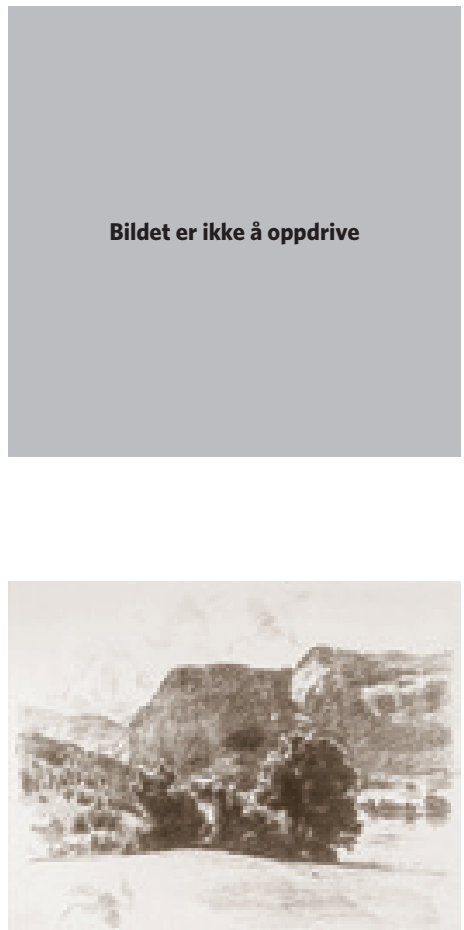
185

Landskap fra Kviteseid II

1925

EW: Opus 95

Litografi

$350 \times 525 \mathrm{~mm}$

Ingen signatur eller datering i

steinen.

187

Ragnar Östberg

1927

EW: Opus 99

Litografi

$390 \times 320 \mathrm{~mm}$

Ingen signatur eller datering i steinen.

Den svenske arkitekten Ragnar Östberg (1866-1945) har blant annet tegnet Stockholms

Stadshus og Zorn-museet i Mora.
186

\section{Landskap fra Kviteseid III}

1925

EW: Opus 96

Litografi

188

Vinter oppi bakken

1928

EW: Opus 97

Litografi

$400 \times 530 \mathrm{~mm}$

Ingen signatur eller datering i steinen.

Motivet er hentet fra Landåsen nord for Gjøvik.
Bildet er ikke å oppdrive
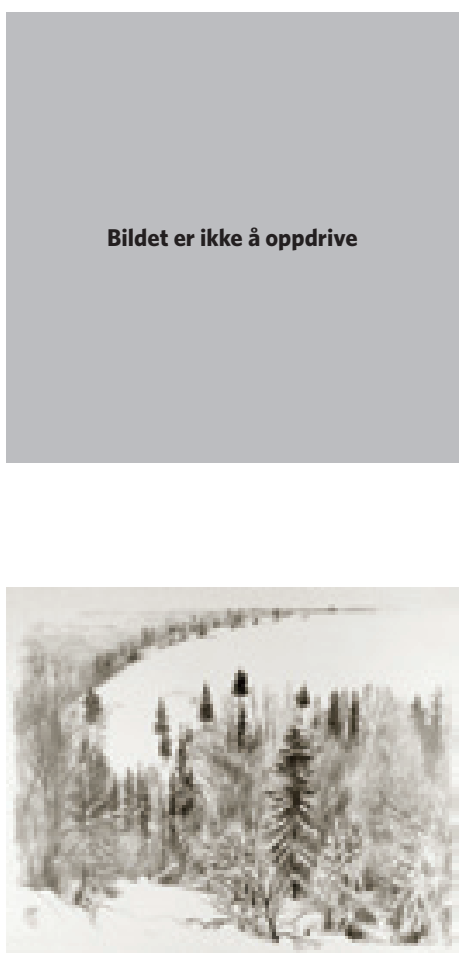
189

Tømmerlasset

1928

EW: Opus 98

Litografi

$400 \times 530 \mathrm{~mm}$

Ingen signatur eller datering i

steinen.

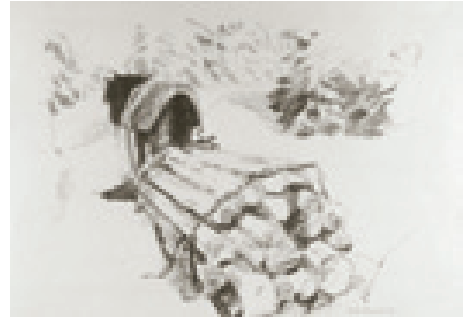

190

Kjemme håret

1928

EW: Opus 100

Litografi

$500 \times 340 \mathrm{~mm}$

Ingen signatur eller datering $\mathrm{i}$ steinen.

192

Fjording i tjor

1928

EW: Opus $100 c$

Litografi

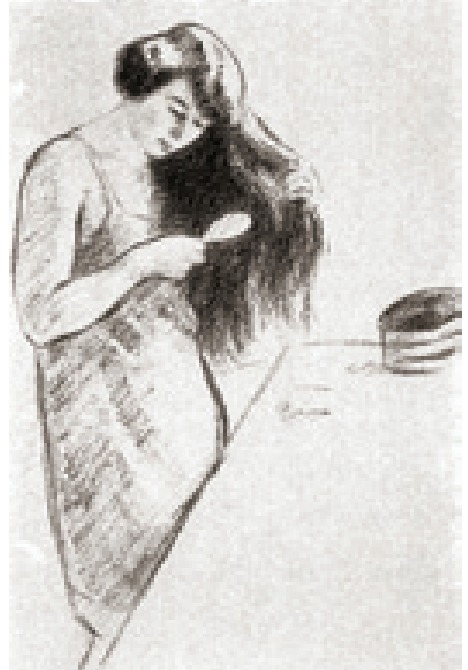

Bildet er ikke å oppdrive
$245 \times 350 \mathrm{~mm}$

Signatur i steinen n.t.h.: EW.

Påskrift n.t.h.: Lofthus//Rauland.

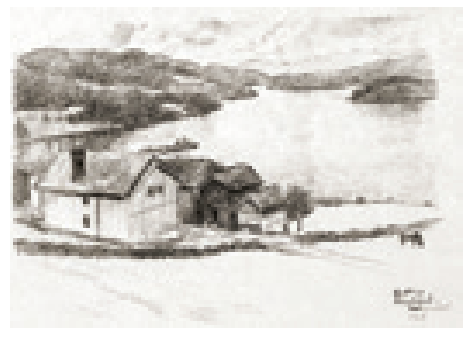

Landskap fra Rauland I

EW: Opus 10ob

Litografi

4 
193

Landskap fra Rauland II

1928

EW: Opus 10od

Litografi

195

Per og Lulla

1928?

EW: Opus 112b

Litografi

$505 \times 405 \mathrm{~mm}$

Ingen signatur eller datering i

steinen.

Per var Erik Werenskiolds barnebarn.

I følge Werenskiolds notater er dette litografiet tegnet tidligere enn Per, Kat.nr. 205.

\section{Bildet er ikke å oppdrive}

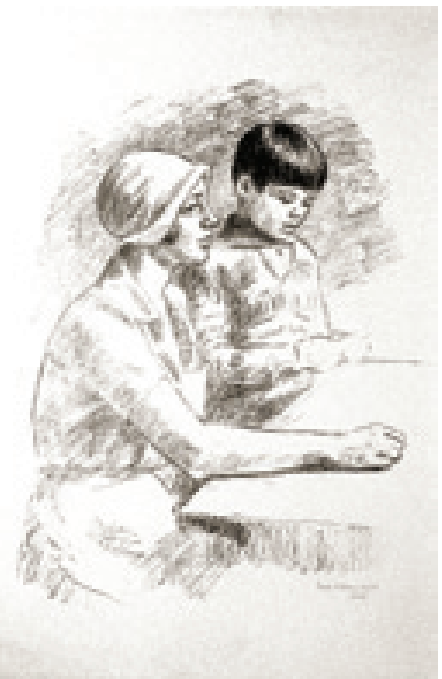

194

Raulandsstranda

1928

EW: Uten opusnummer

Litografi

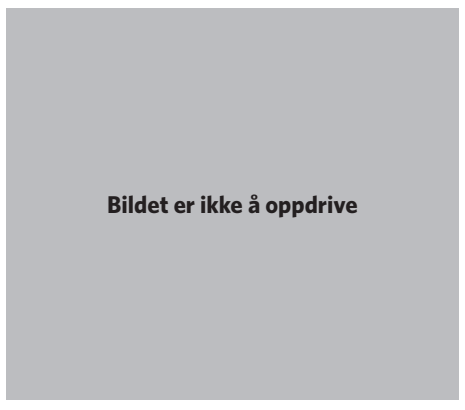

Sommervind. Oslofjorden 1929

EW: Opus 101

Litografi $400 \times 490 \mathrm{~mm}$

Ingen signatur eller datering $\mathrm{i}$ steinen.

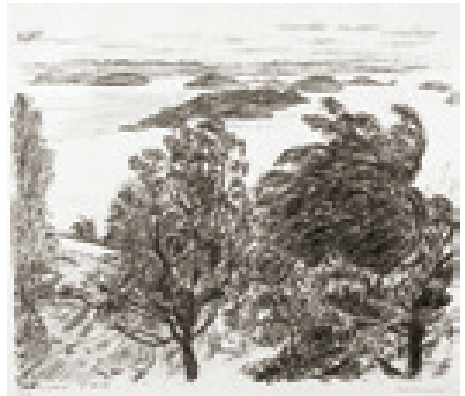


Den hvite dame

1929

EW: Opus 102

Litografi

$495 \times 330 \mathrm{~mm}$

Ingen signatur eller datering i steinen.

Den portretterte er Ingeborg Holmboe, datter av Arnold

(justisminister og senere

finansminister) og Dagmar

Theodore Holmboe, født

Dahlmann.

199

\section{Gardisten}

1929

EW: Opus 104

Litografi

$556 \times 185 \mathrm{~mm}$

Ingen signatur eller datering steinen.

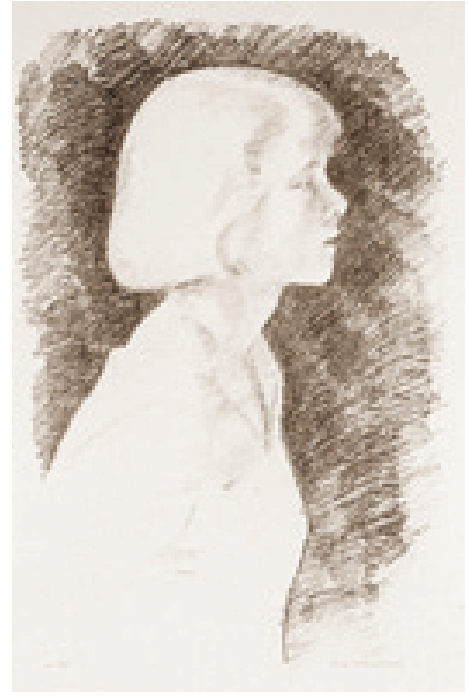

Glomma fra Kongsvinger festning

1929

EW: Opus 103

Litografi

$410 \times 595 \mathrm{~mm}$

Ingen signatur eller datering i steinen.

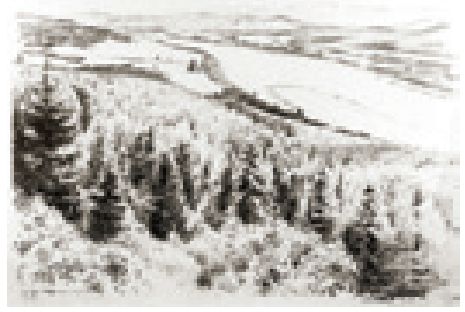

200

Katten

1929

EW: Opus 105

Litografi

$414 \times 505 \mathrm{~mm}$

Ingen signatur eller datering i steinen.

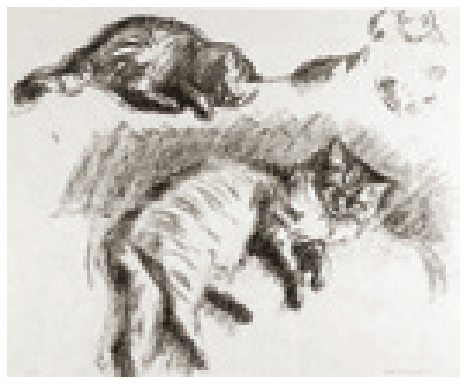


201

Folungen II

1929

EW: Opus 108

Litografi

$338 \times 505 \mathrm{~mm}$

Ingen signatur eller datering i steinen.

Motivet er fra Haugastø

203

Ørtebekken

1929

EW: Opus 110

Litografi

$440 \times 600 \mathrm{~mm}$

Ingen signatur eller datering i

steinen.

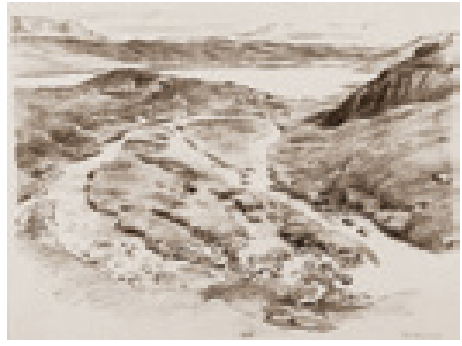

Motivet er fra Haugastøl.
202

Hest med føll på fjellet

1929

EW: Opus 109

Litografi

$420 \times 590 \mathrm{~mm}$

Motivet er fra Haugastøl.

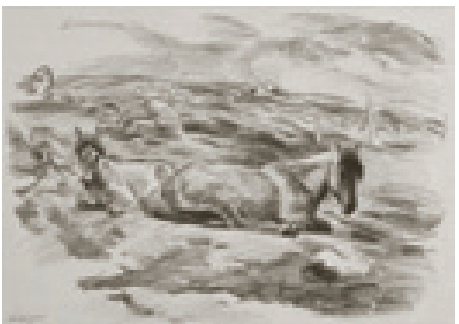

204

Bjørn

1929

EW: Opus 111

Litografi

$340 \times 455 \mathrm{~mm}$

Ingen signatur eller datering i

steinen.

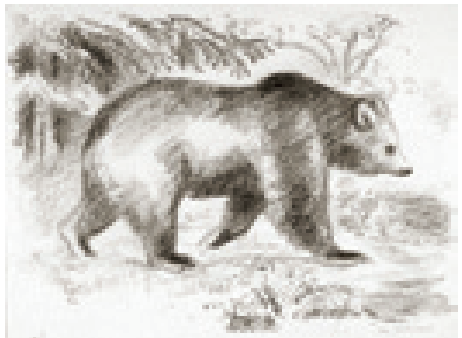




\section{5}

1929

EW: Opus 112

Litografi

$390 \times 560 \mathrm{~mm}$

Ingen signatur eller datering $\mathrm{i}$ steinen.

I følge Werenskiolds notater er dette litografiet basert på en

tidligere tegning med samme

motiv. Per er Erik Werenskiolds barnebarn.

207

Gutten som hugger hodene av trollet II

1930

EW: Opus 107

Litografi

$565 \times 438 \mathrm{~mm}$

Ingen signatur eller datering i steinen.
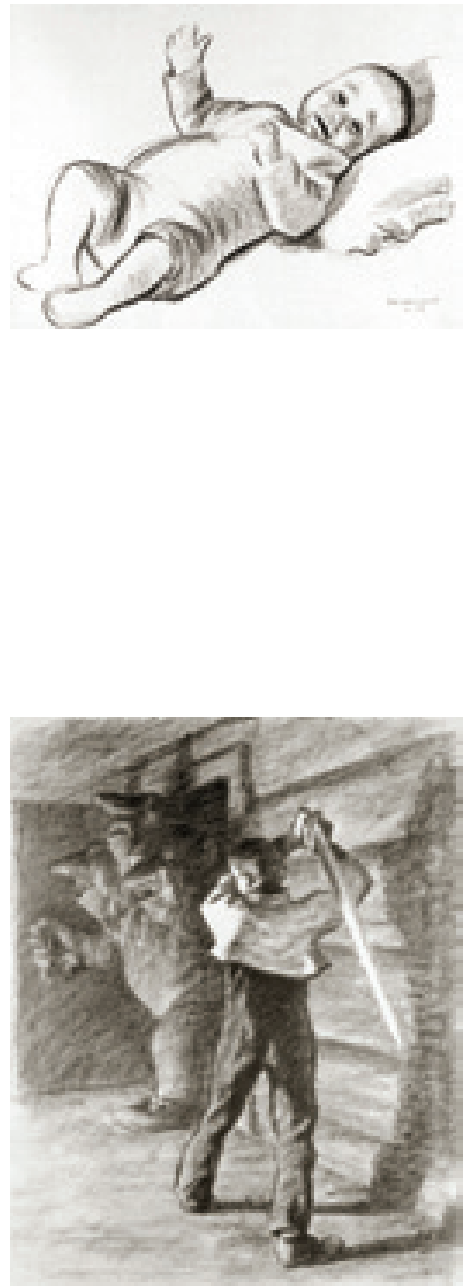

Gutten som hugger hodene av trollet I

1929

EW: Opus 106

Litografi

$565 \times 438 \mathrm{~mm}$

Ingen signatur eller datering i steinen.

208

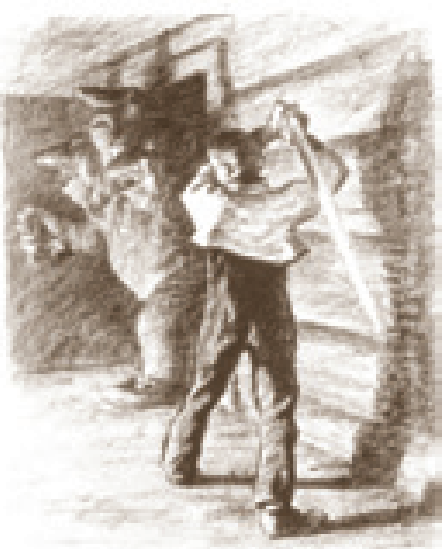

Fra Vangsmjøsa I

1930

EW: Opus 113

Litografi

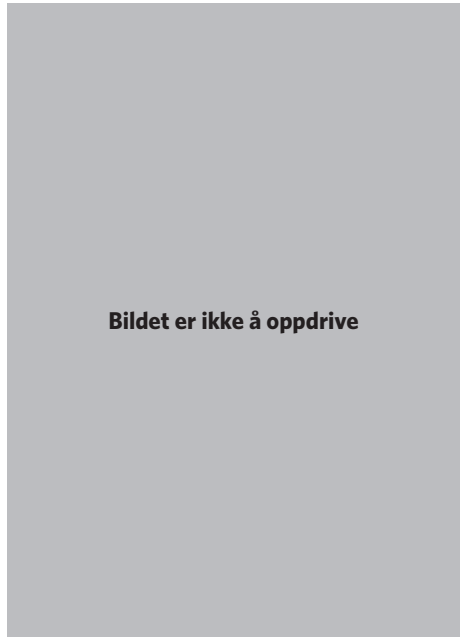


209

Fra Vangsmjøsa II

1930

EW: Opus $113 b$

Litografi

$374 \times 545 \mathrm{~mm}$

Ingen signatur eller datering i steinen.

Skutshorn i bakgrunnen.

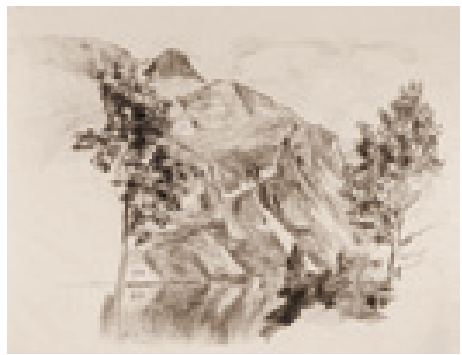

Olaf Berge I

1930

EW: Opus 114

Litografi

$565 \times 438 \mathrm{~mm}$

Signatur og datering i steinen n.t.h.: Tyriholmen 1930//EW.

Påskrift på trykket n.t.h.: Olaf Berge 6 år//Eg trudde ikje Du var//såpass Te kar!

\section{Fra Tyriholmen}

1930

EW: Uten opusnummer

Litografi

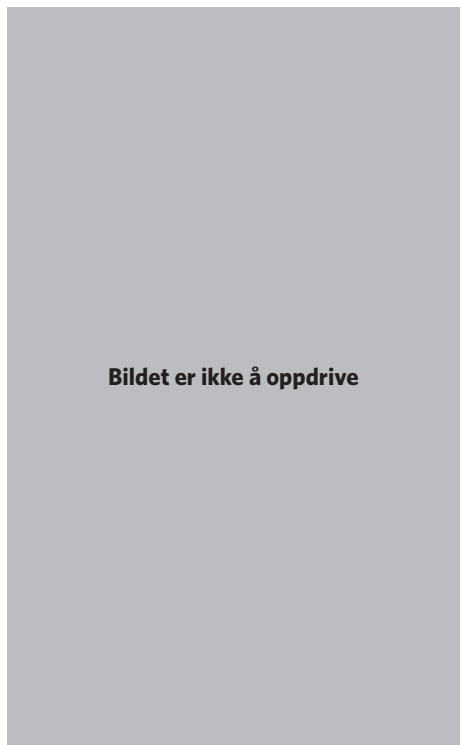

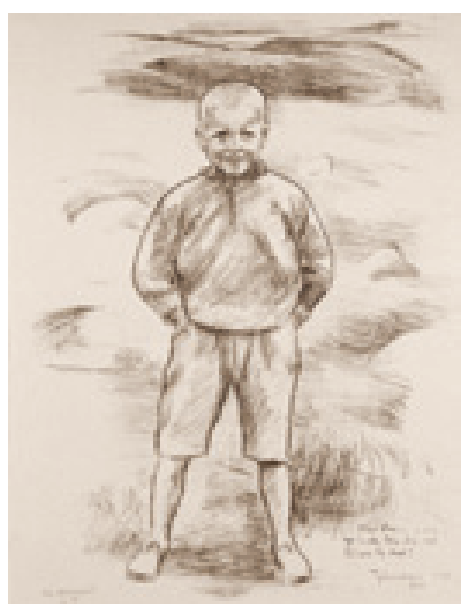

EW: Opus 115

Litografi

$560 \times 322 \mathrm{~mm}$

Ingen signatur eller datering i steinen.

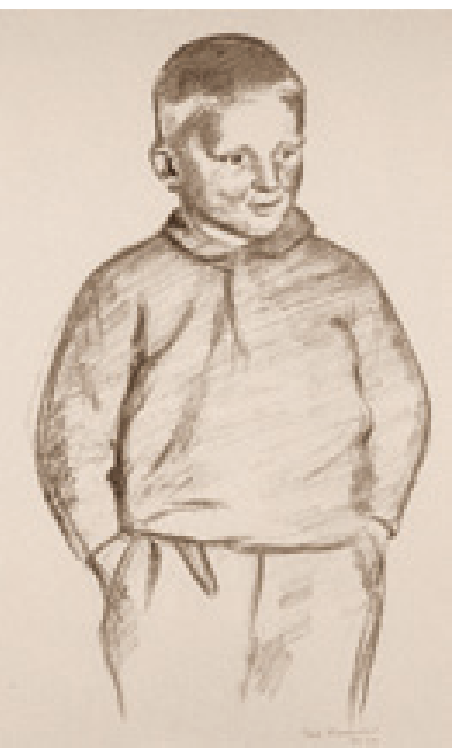


213

Nils Berg

1931

EW: Opus 116

Litografi

$370 \times 310 \mathrm{~mm}$

Ingen signatur eller datering steinen.

Nils Berg (1827-1911) var sønn av Christopher og Olava Berg født Finden. Nils Berg hadde

hovedansvar for et glassverke på Biri, og var medeier i Høvik Verk og Hadeland Glassverk

sammen med sine brødre Harald og Ole Chr.

215

Falketind II

1931

EW: Opus 117

Litografi

$465 \times 605 \mathrm{~mm}$

Ingen signatur eller datering i steinen.

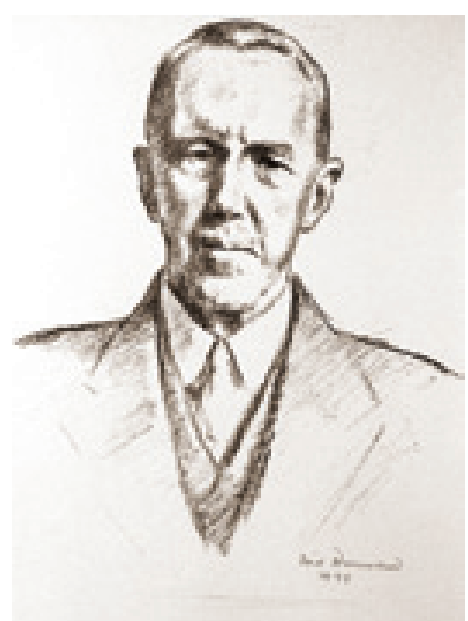

214

\section{Falketind I}

1931

EW: Uten opusnummer

Litografi

$465 \times 605 \mathrm{~mm}$

Ingen signatur eller datering $\mathrm{i}$ steinen.

"Det gamle" Falketind-motive ifølge Werenskiolds notater.

216

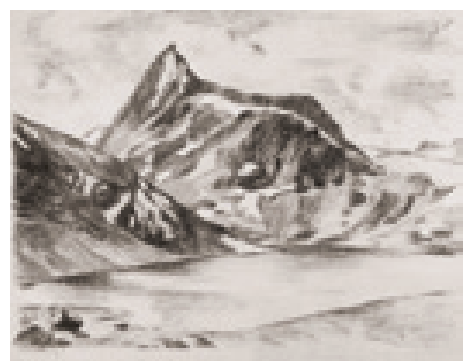

931

EW: Opus 118

Litografi

$370 \times 560 \mathrm{~mm}$

Ingen signatur eller datering i steinen.
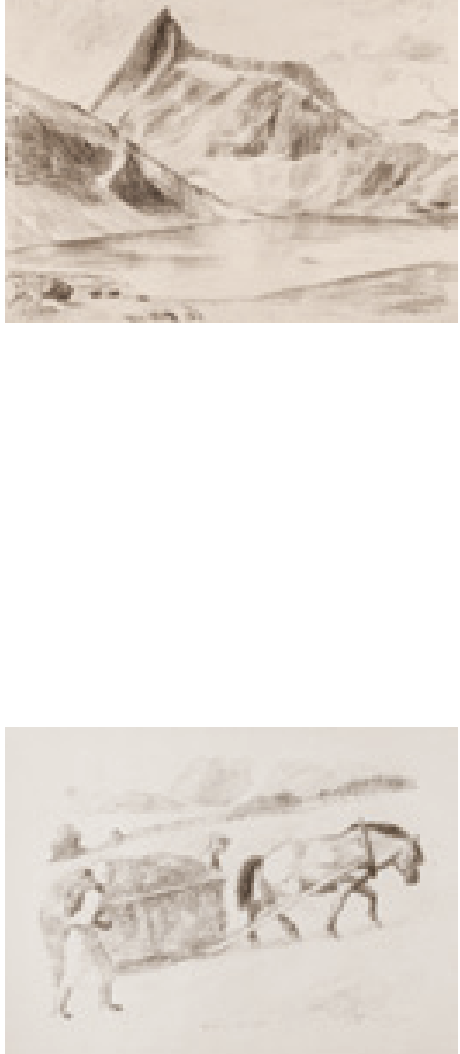
217

Huldra II

1933

EW: Opus 119

Litografi

$470 \times 612 \mathrm{~mm}$

Ingen signatur eller datering steinen.

Noen eksemplarer er

håndkolorert med fargeblyant.
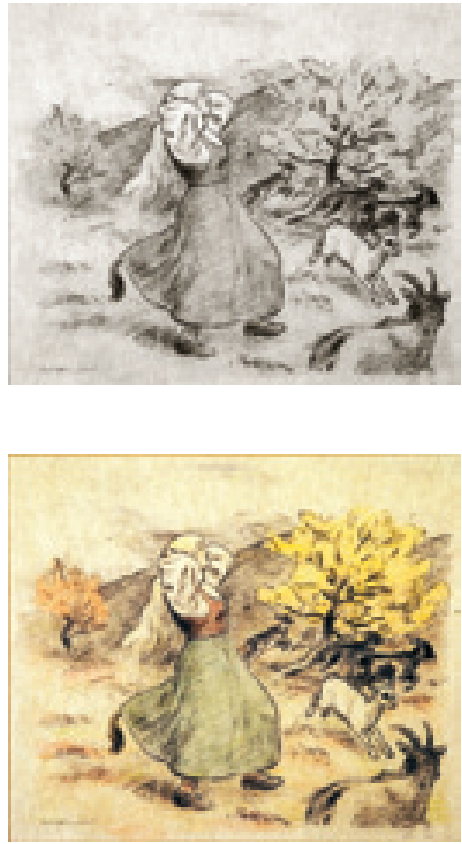

219

Høylasset oppover låvebrua 1933

EW: Opus 121

Litografi

$390 \times 590 \mathrm{~mm}$

Ingen signatur eller datering steinen.
218

Huldra III

1933

EW: Opus 120

Litografi

$462 \times 582 \mathrm{~mm}$

Ingen signatur eller datering i steinen.

Noen eksemplarer er

håndkolorert med fargeblyant.

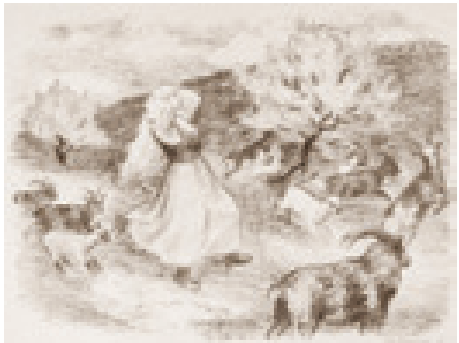

Fjordhesten

1933

EW: Opus 122

Litografi

$325 \times 495 \mathrm{~mm}$

Ingen signatur eller datering $\mathrm{i}$ steinen.

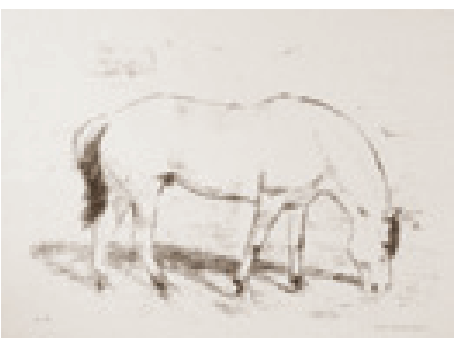




\section{1 \\ Wergeland på Veslebrunen I}

1934

EW: Opus 123

Litografi

$600 \times 743 \mathrm{~mm}$

Ingen signatur eller datering steinen.

Henrik Wergeland (1808-1845), sønn av Nicolai og Alette

Dorothea Wergeland, født

Thaulow. Bror av Camilla Collett

og Oscar Wergeland.

\section{3}

\section{Djupvassfossen}

1934

EW: Opus 124

Litografi

$480 \times 605 \mathrm{~mm}$

Ingen signatur eller datering steinen.

Motivet er fra Hol i Hallingdal.
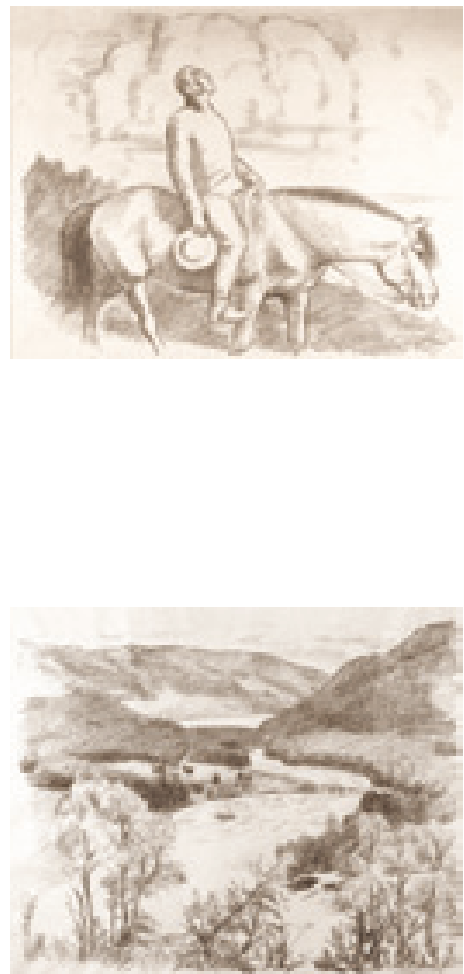

222

Wergeland på Veslebrunen III

1934

EW: Uten opusnummer

Litografi

$650 \times 830 \mathrm{~mm}$

Ingen signatur eller datering i steinen.

Henrik Wergeland (1808-1845), sønn av Nicolai og Alette

Dorothea Wergeland, født

Thaulow. Bror av Camilla Collett og Oscar Wergeland.

\section{4}

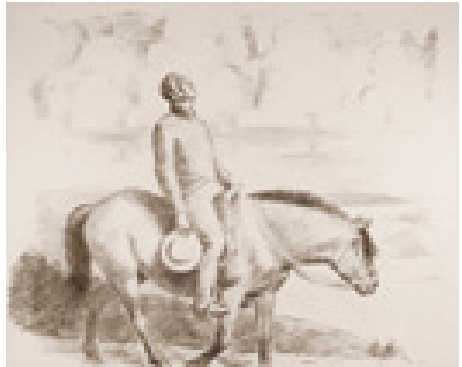

1934

EW: Opus 128

Litografi
Bildet er ikke å oppdrive 
225

Jens Werenskiold Berg

1934

EW: Opus 129

Litografi

$370 \times 275 \mathrm{~mm}$

Ingen signatur eller datering $\mathrm{i}$ steinen.

Jens Werenskiold Berg (1868-)

var glassverkseier. Sønn av Ole

Christopher Berg og Elisabeth

Magdalene Berg, født

Werenskiold. Nils Bergs nevø,

Kat.nr. 213.

\section{7}

Falketind III

1935

EW: Opus 125

Litografi

$480 \times 600 \mathrm{~mm}$

Ingen signatur eller datering

steinen.

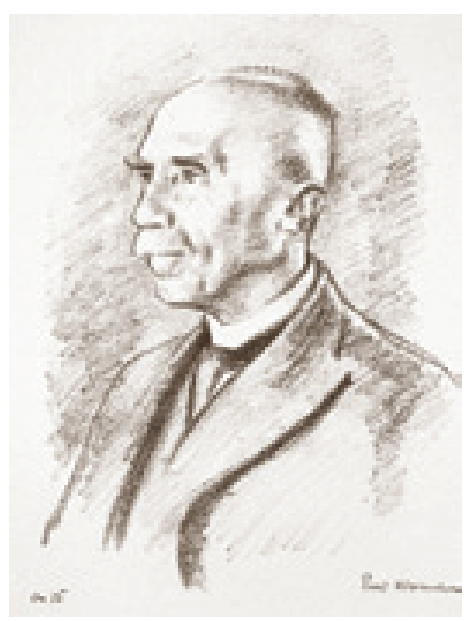

226

\section{Kuene}

1935

EW: Opus 130

Litografi

$250 \times 360 \mathrm{~mm}$

Ingen signatur eller datering i steinen.

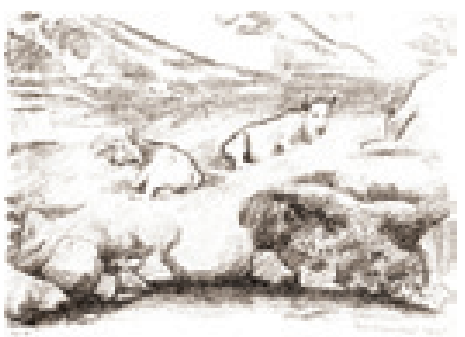

228

Som en blomst

1935

EW: Opus 126

Litografi

$595 \times 470 \mathrm{~mm}$

Ingen signatur eller datering $\mathrm{i}$ steinen.

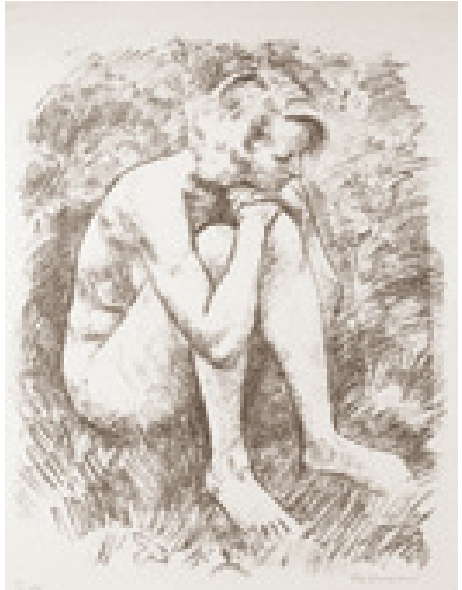


229

Alle skogens dyr

1935

EW: Opus 127

Litografi

$302 \times 298 \mathrm{~mm}$

Signert i steinen n.t.h.: EW

Tilnærmet samme motiv er også malt som akvarell i 1935.
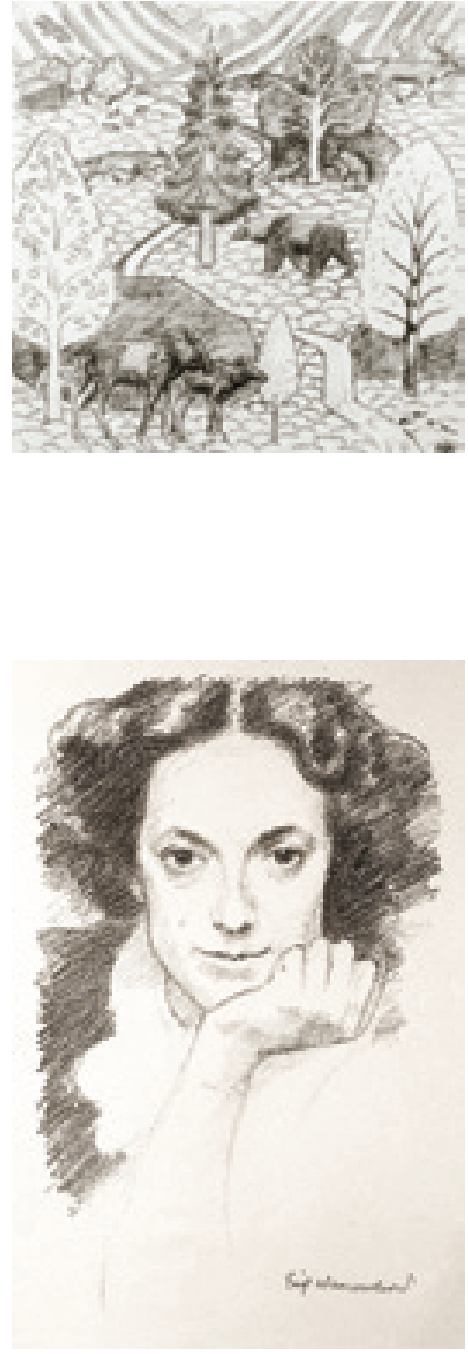

230

Thorleif Schjelderup

1935 ?

EW: Opus 135

Litografi

$315 \times 320 \mathrm{~mm}$

Ingen signatur eller datering i steinen.

Thorleif Frederik Schjelderup (1859-1931) var forretningsmann og sønn av Thorleif og Frederikk Marie Schjelderup, født Caspary.

232

\section{Eva Nansen}

1935-1937?

EW: Uten opusnummer

Litografi

$450 \times 370 \mathrm{~mm}$

Ingen signatur eller datering i steinen.

Sangerinnen Eva Nansen (1858-1907), født Sars, gift med Fridtjof Nansen.
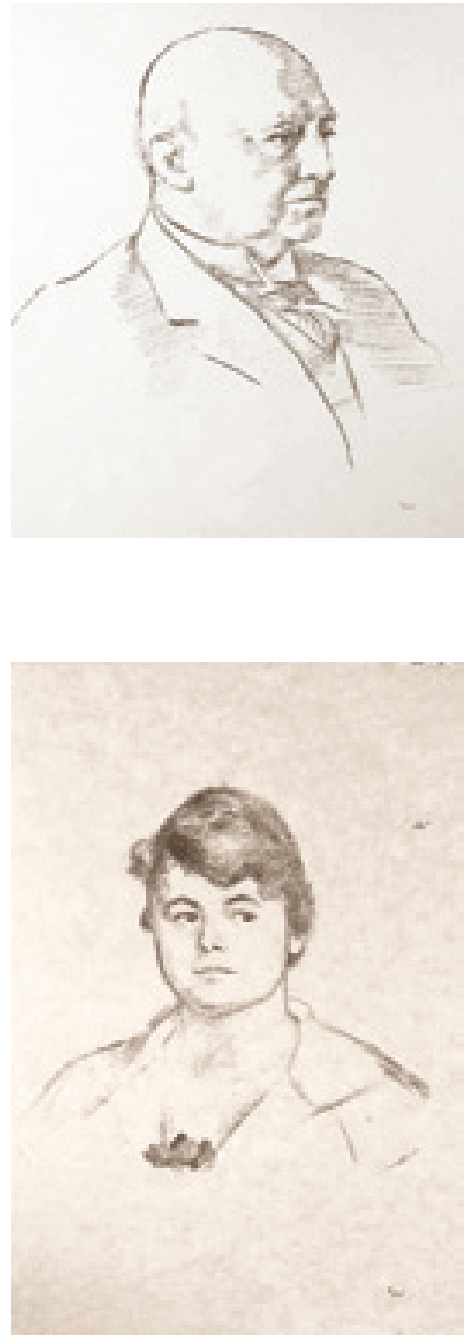


\section{Mally Lammers}

1935-1937?

EW: Opus 137a

Litografi

$380 \times 330 \mathrm{~mm}$

Ingen signatur eller datering steinen.

Sangerinnen Mally Lammers (1850-1929), født Sars, er søster av Eva Nansen.

\section{5}

Thorvald Lammers II

1935-1937?

EW: Uten opusnummer

Litografi

$235 \times 170 \mathrm{~mm}$

Ingen signatur eller datering i steinen.

Thorvald Amund Lammers (1841-1922) var en av sin tids store sangere. Han var også komponist og dirigent. 1890-årene begynte han et betydningsfullt arbeid for å øke folks kjennskap til norsk folkemusikk. Gift med

sangerinnen Mally Lammers, født Sars.

\section{4}

\section{Thorvald Lammers}

1935-1937?

EW: Uten opusnummer

Litografi

$260 \times 210 \mathrm{~mm}$

Ingen signatur eller datering i steinen.

Thorvald Amund Lammers (1841-1922) var en av sin tids store sangere. Han var også komponist og dirigent. 1890-årene begynte han et betydningsfullt arbeid for å $ø$ øefolks kjennskap til norsk folkemusikk. Gift med

sangerinnen Mally Lammers, født Sars.

236

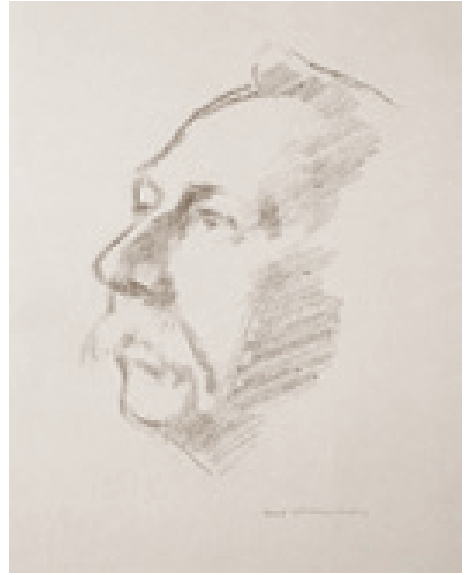

Svartdal

1935-1937?

EW: Opus 139

Litografi

$467 \times 600 \mathrm{~mm}$

Ingen signatur eller datering i steinen.

Fjellet Knutshø i bakgrunnen.
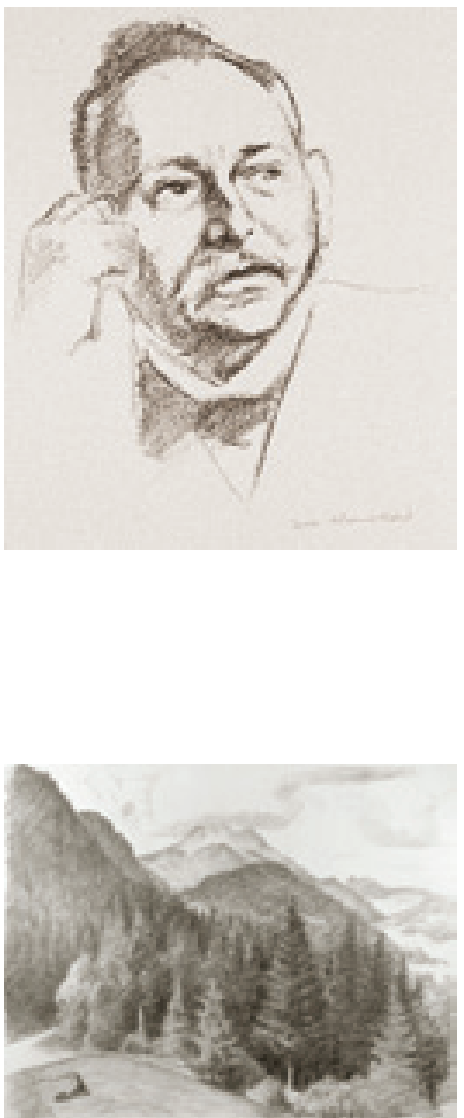
237

Flette håret

1935-1937?

EW: Opus 144

Litografi

$520 \times 400 \mathrm{~mm}$

Ingen signatur eller datering i

steinen.

239

Vaske beina

1935-1937?

EW: Opus 148

Litografi

$418 \times 546 \mathrm{~mm}$

Ingen signatur eller datering $\mathrm{i}$ steinen.

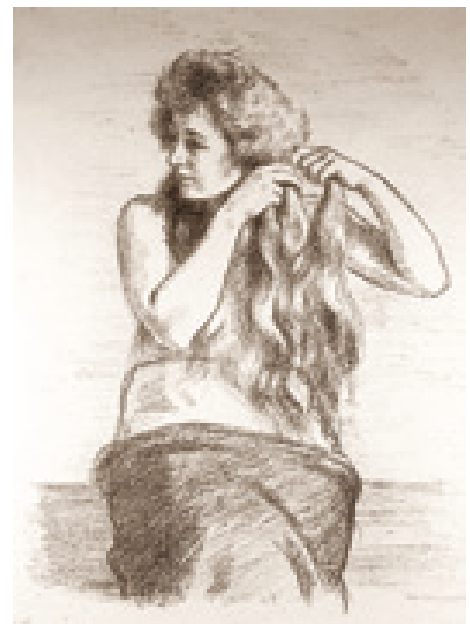

238

Dame med hatt og pels

1935-1937?

EW: Opus 147

Litografi

$372 \times 290 \mathrm{~mm}$

Ingen signatur eller datering $\mathrm{i}$ steinen.

\section{0}

Liten gutt med skyggelue 1935-1937?

EW: Uten opusnummer

Litografi

$555 \times 420 \mathrm{~mm}$

Ingen signatur eller datering i steinen.
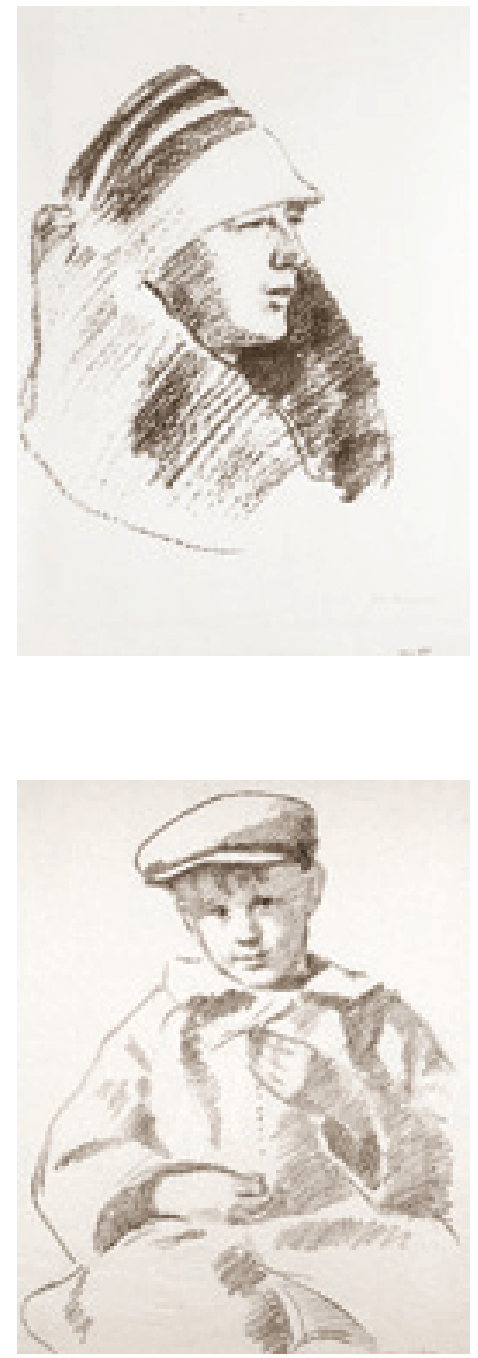
241

Magnus Poulsson

1935-1937?

EW: Uten opusnummer

\section{Litografi}

Magnus Poulsson (1881-1954) var en av Norges mest markante arkitekter i første halvdel av 1900-tallet. Han tegnet bl.a. Oslo

rådhus sammen med Arnstein

Arneberg.

Poulsson var gift med Anna

Poulsson, født Bache-Wiig.

243

Smågutt ved stranda

1935-1937?

EW: Uten opusnumme

Litografi
242

Liten pike

1935-1937?

EW: Uten opusnummer

Litografi

Bildet er ikke å oppdrive

O. Thommesen

1935-1937?

EW: Uten opusnummer

Litografi

Ola (Olaus Anthon)

Thommessen (1851-1942) var leder for Verdens Gang og Tidens Tegn mellom 1880 og 1920. Sønn av Thommes K. og Hella Marie
Bildet er ikke å oppdrive
Bildet er ikke å oppdrive Bildet er ikke å oppdrive
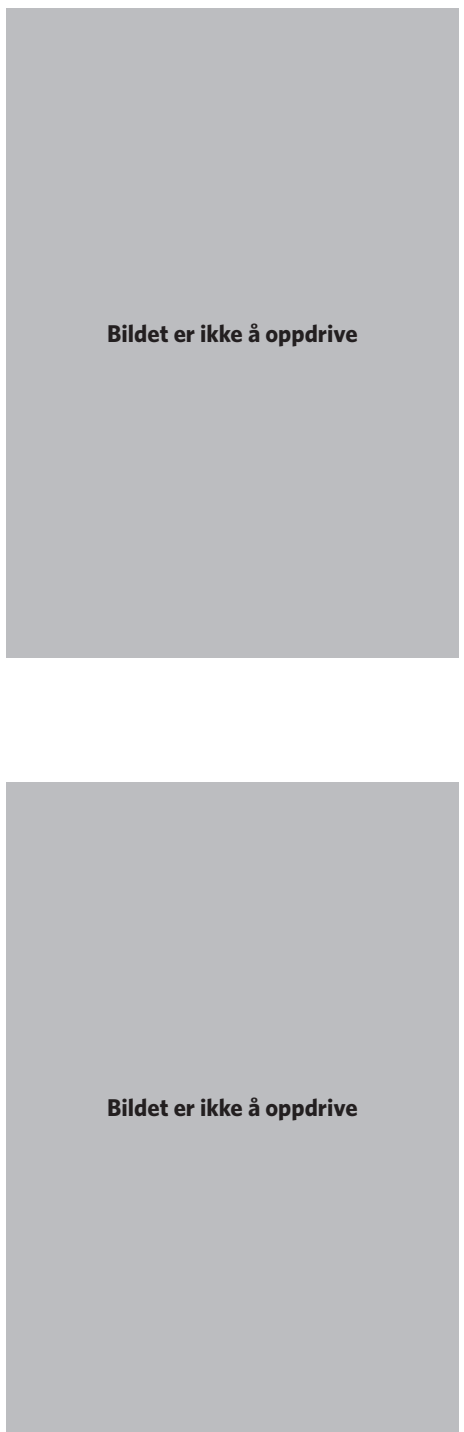


\section{5}

\section{Dagfin III}

1935-1937?

EW: Uten opusnummer

Litografi

Dagfin Werenskiold (1892-1977), kunstner og sønn av Erik og Sophie Marie Werenskiold, født

Stoltenberg Thomesen.

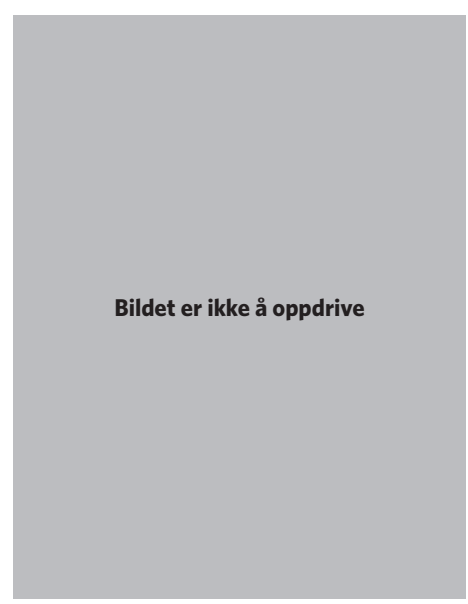

\section{7}

Lensekara II

1938

EW: Opus 132

Litografi

$807 \times 626 \mathrm{~mm}$

Ingen signatur eller datering steinen.

\section{6}

\section{Lensekara I}

november 1937

EW: Opus 131

Litografi

$540 \times 450 \mathrm{~mm}$

Ingen signatur eller datering $\mathrm{i}$ trykket.

Trykt hos Thon i Staffelsgate 2 Maskintrykk. Litografiet er gjort på grunnlag av malerstudie. Motivet ble gjengitt på 4. utgaven av hundrekroneseddelen som vari omløp fra 1949 til 1962

Arnstein Arneberg hadde stått for seddelens utforming.

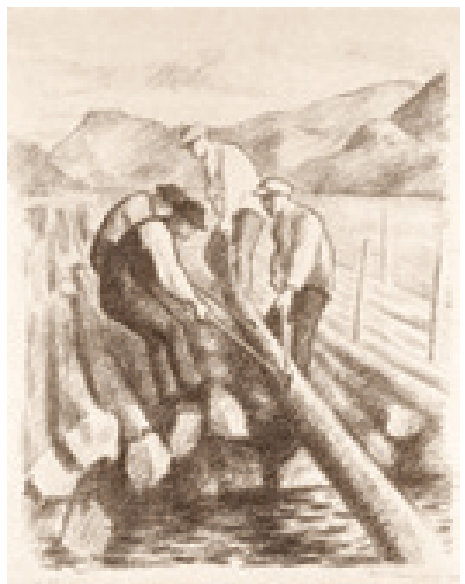

Werenskiold skriver i sine notater: "Tømmeret måtte i Sundkilen (Kviteseid) og andre steder ovenfor Bandak- kanalen 'klubbes'. [Det vil si] pakkes sammen i 'klubber' så de kunde passere kanalen."

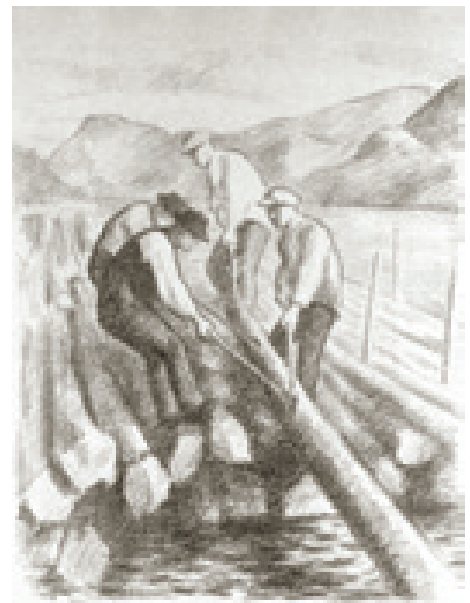




\section{APPENDIKS I}

\section{Gyldendal Norsk Forlag 1937}

Erik Werenskiold

24 tegninger reprodusert som autotypier utgitt i mappe

Trykk:

Dreyers Grafiske Anstalt, Stavanger 
Nr. 1

Fan i Fryksende

1887

$248 \times 362 \mathrm{~mm}$

Illustrasjon i Djurklos eventyr

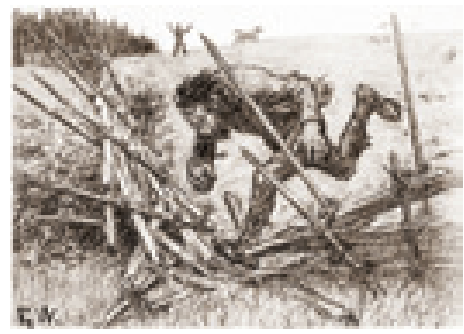

Nr. 3

Lars Fiskerhytta

1892

$400 \times 275 \mathrm{~mm}$
Nr. 2

Jacob Gløersen

1892

$385 \times 295 \mathrm{~mm}$

Nr. 4

Fridtjof Nansen

1893

$355 \times 280 \mathrm{~mm}$
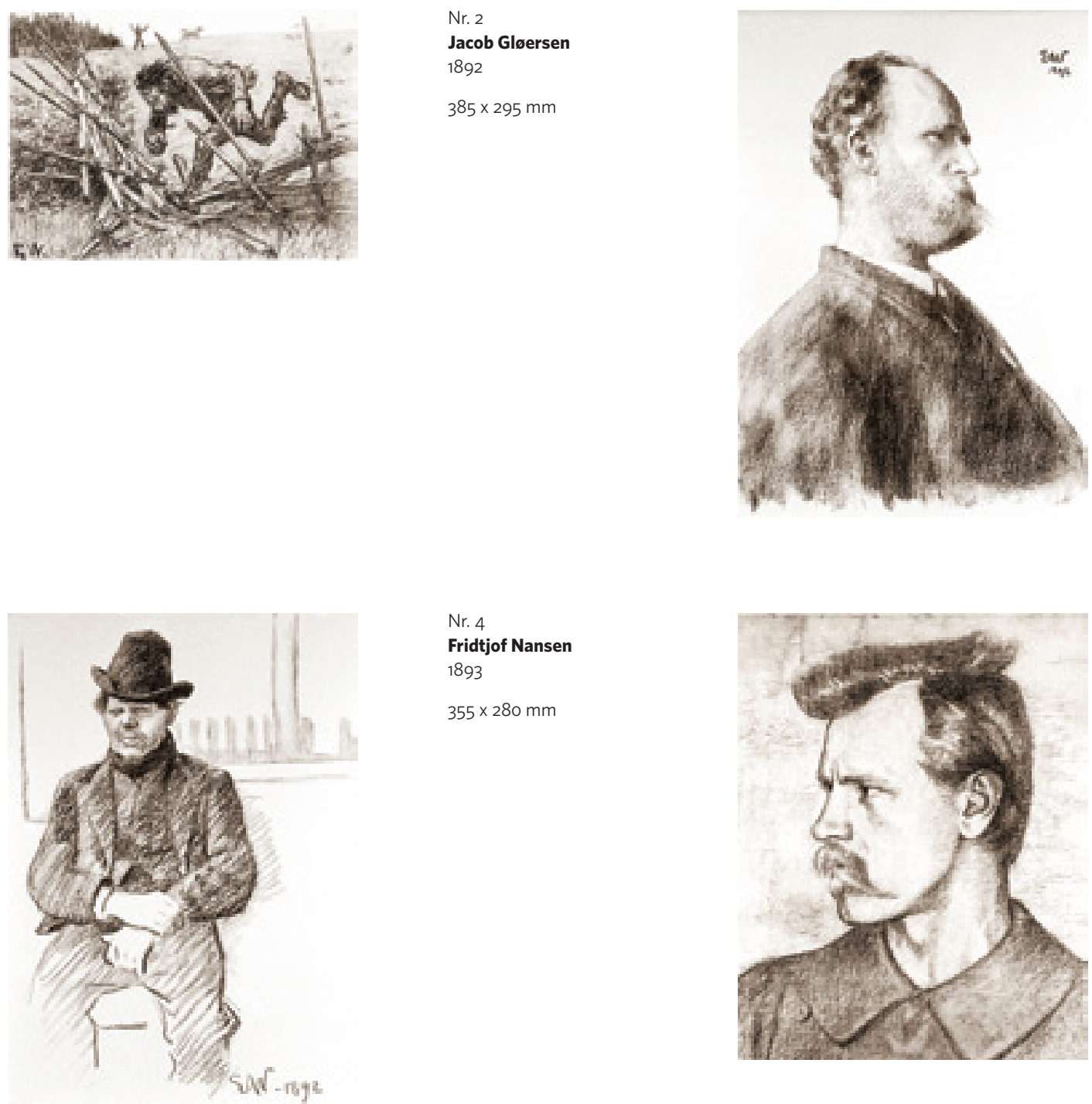
Nr. 5

Eva Nansen og Liv

1893

$320 \times 295 \mathrm{~mm}$

Nr. 7

Bjørnstjerne Bjørnson 1895

$330 \times 280 \mathrm{~mm}$

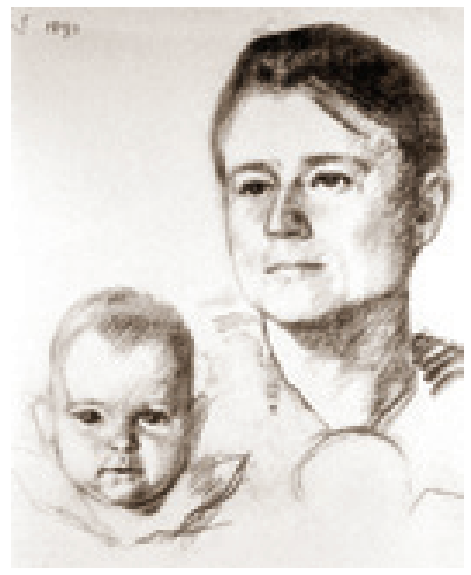

Nr. 6

Barna ved ovnen

1894

$143 \times 121 \mathrm{~mm}$

Illustrasjon i Familien på Gilje

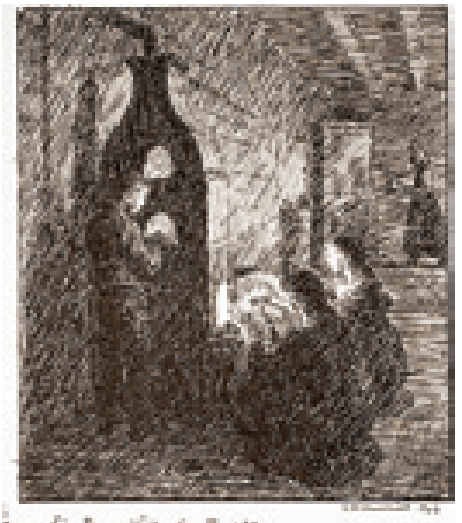

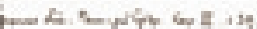

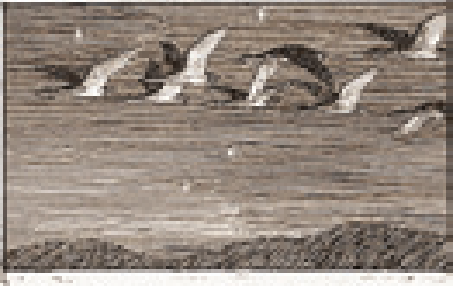

rea,
Grågjessene

1898

$78 \times 133 \mathrm{~mm}$

Illustrasjon i Familien på Gilje

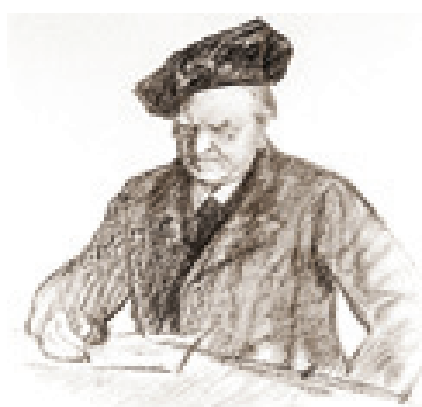

Sat R. 
Nr. 9

Olav og hans menn drar til dronning Geira

1895-1899

$88 \times 151 \mathrm{~mm}$

Illustrasjon i Olav Trygvessons saga

Nr. 11

Erling Skjalgsson setter dagarbeid for trellene sine 1885-1899

$100 \times 170 \mathrm{~mm}$

Variant av illustrasjon i Olav den Helliges saga
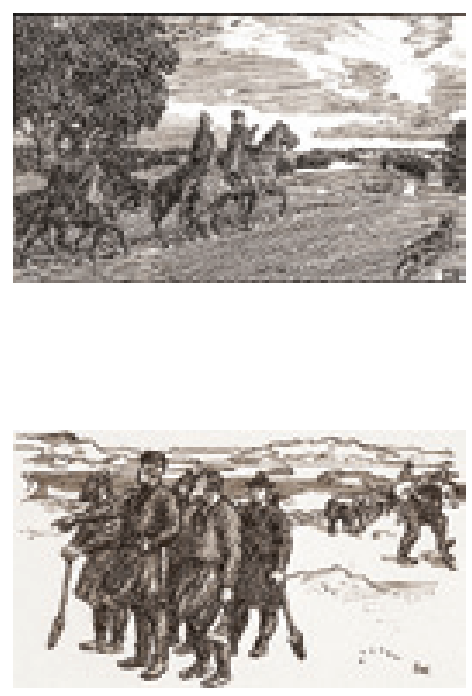

Nr. 10

Seierherrenes skip vender hjem etter slaget ved Svolder

1895-1899

$122 \times 190 \mathrm{~mm}$

Illustrasjon i Olav Trygvessons saga

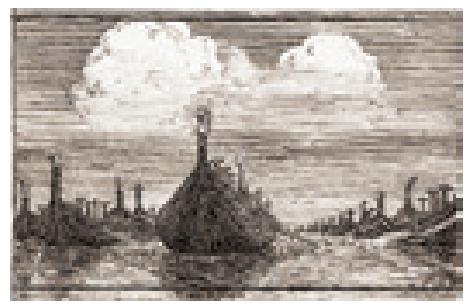

Nr. 12

Kong Olav rir til Opplandstinget på Eidsvoll

1895-1899

$105 \times 126 \mathrm{~mm}$

Illustrasjon i Olav den Helliges saga

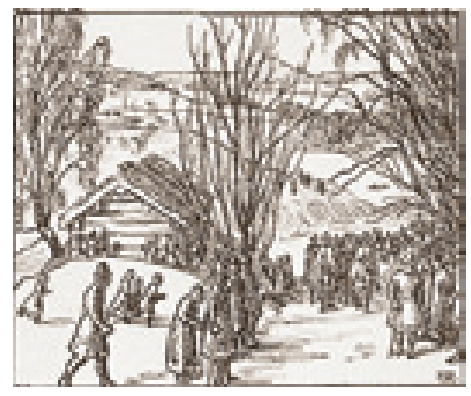


Nr. 13

Asbjørn Selsbane går innover Karmøy mot Avaldsneset

1885-1899

$83 \times 160 \mathrm{~mm}$

Illustrasjon i Olav den Helliges saga

Nr. 15

Edvard Grieg

1902

$265 \times 355 \mathrm{~mm}$

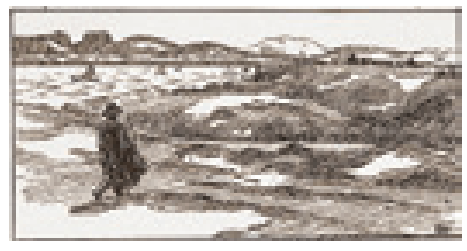

Nr. 14

Det var gråt og jamring av de hærsatte folk

1895-1899

$85 \times 193 \mathrm{~mm}$

Illustrasjon i Olav den Helliges saga

Nr. 16

På fjellet

1902

$285 \times 377$

Variant av illustrasjon i Familien på Gilje
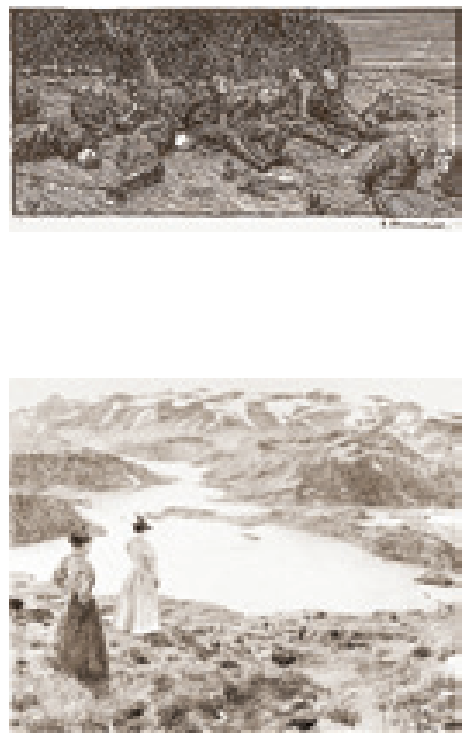
Nr. 17

Kapteinens død

1902

$270 \times 320 \mathrm{~mm}$

Variant av illustrasjon i Familien på Gilje

Nr. 19

Thinka og Ma

1904

$240 \times 245 \mathrm{~mm}$

Studie til illustrasjon i Familien på Gilje

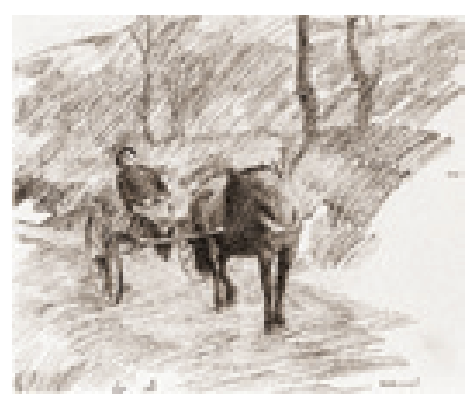

Nr. 18

Siste par ut

1903

$175 \times 160 \mathrm{~mm}$

Variant av illustrasjon i Familien på Gilje

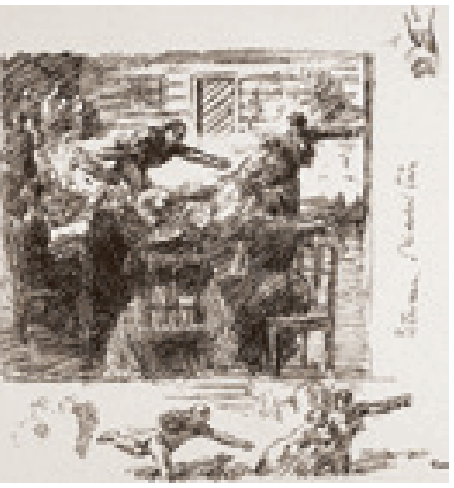

Nr. 20

J.E. Sars

1905

$272 \times 249 \mathrm{~mm}$

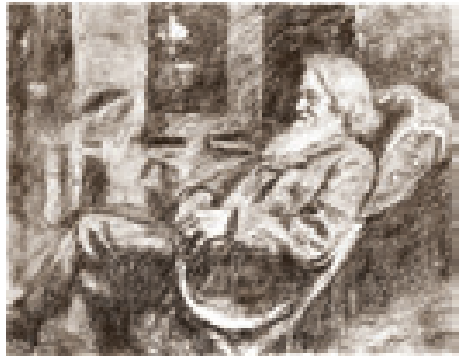


Nr. 21

Henrik Ibsen

1905

$370 \times 285 \mathrm{~mm}$

Nr. 23

Liti Kjersti

1910

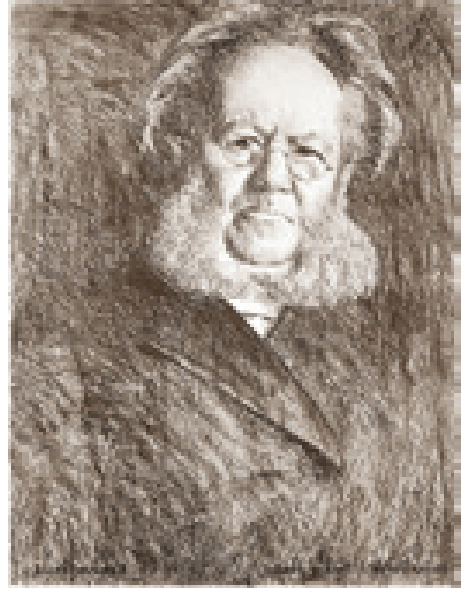

Chr. Michelsen 1906

$350 \times 280 \mathrm{~mm}$

Nr. 24

Nini Roll Anker

1920

$130 \times 142 \mathrm{~mm}$
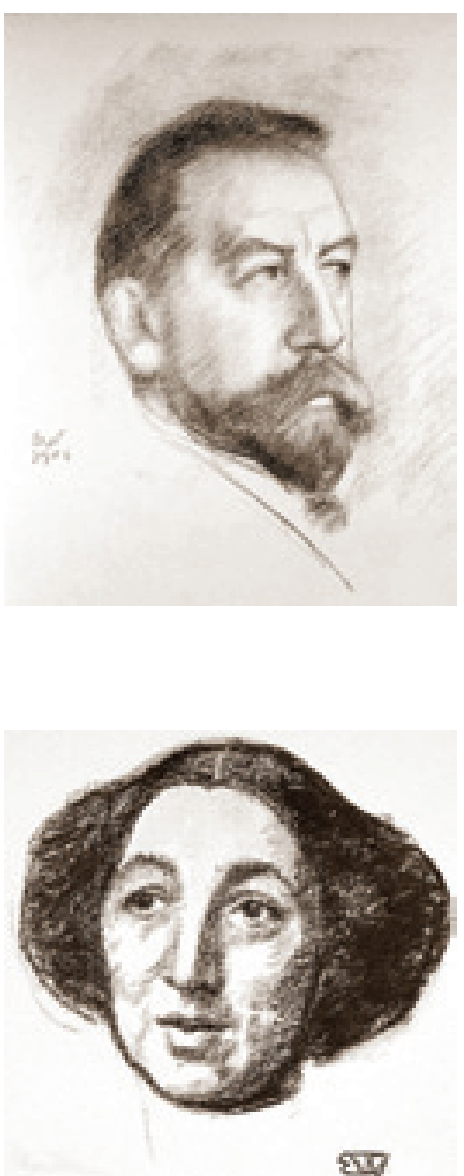

APPENDIKS II

3 autotypier

171 
Høyfjell

Autotypi

$230 \times 300 \mathrm{~mm}$

Opprinnelig streketsning, 1908-1909.

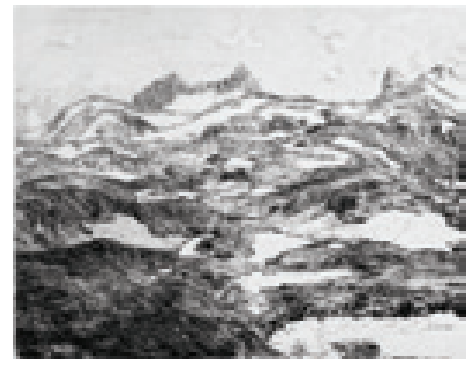

\section{Nedsnødde smågraner}

Autotyp

$308 \times 235 \mathrm{~mm}$

Opprinnelig streketsning, 1913

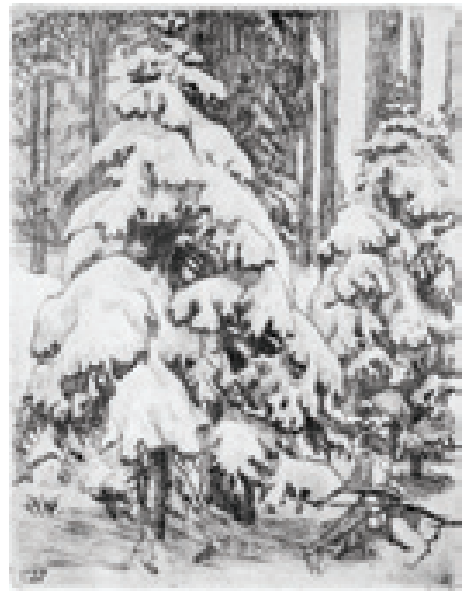

Tone og Bebe

Autotypi

$310 \times 242 \mathrm{~mm}$

Opprinnelig litografi, 1922.

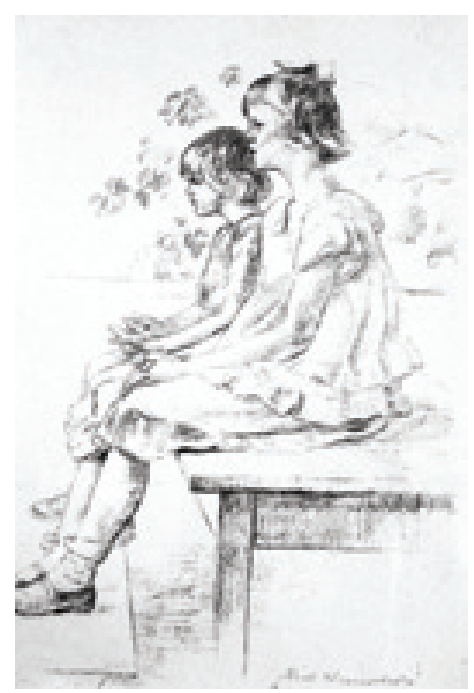




\section{Bibliografi, katalog}

Berg, Knut (red.). Norges kunsthistorie. Nasjonal vekst. Bind 5. Oslo: Gyldendal Norsk Forlag, 1981.

Borum. En bygds historie. 1924. Bind II. Utgitt av Bærums herredsstyre.

Helliesen, Sidsel. Norsk grafikk gjennom 100 år. Oslo: Aschehoug, 2000.

Høiem, Per. Håkon Bleken. Grafikk 1947-2003. Oslo: Labyrinth Press, 2003.

Norsk kunstnerleksikon. Bind 1 og 4. Oslo: Universitetsforlaget A.S., 1986.

Katalog til "Minneutstilling sort og hvitt", Kunstnernes Hus, Oslo, 6.-28. januar 1940.

Werenskiold, Erik. Brev fra Erik Werenskiold til Bernt Grønvold. Brevsamling 98. Nasjonalbibliotekets håndskriftsamling.

Werenskiold, Erik. Håndskrevne notater og grafikkoversikt. "Raderinger og litografier”. Lysaker, påbegynt 1909.

Werenskiold, Marit. De norske Matisse-elevene: Loeretid og gjennombrudd 1908-1914. Oslo: Gyldendal Norsk Forlag, 1972.

Woll, Gerd. Edvard Munch. The Complete Graphic Works. London og Oslo: Philip Wilson Publishers i samarbeid med Munch-museet. 



\section{Alfabetisk oversikt}

\begin{tabular}{lccc}
\hline Tittel & Datering & EW & Katalognummer \\
\hline Alle skogens dyr & 1935 & Opus 127 & 229 \\
Anton Klavenes til hest & 1917 & Opus 2 & 79 \\
Asketre med fabrikk & $1919 ?$ & Opus 40 & 126 \\
Aspen med Besshø & 1913 & Opus 41 & 47 \\
Axel Heiberg & 1915 & Opus 61 & 69 \\
Baskens Ex libris. Reinblom & 1921 & Opus 71 & 160 \\
Bebe og Lisbeth & 1922 & & 177 \\
Besshø & 1913 & Opus 43 & 49 \\
Bjørkene ved jernbanelinjen & 1910 & Opus 18 & 22 \\
Bjørn & 1929 & Opus 111 & 204 \\
Bjørnsons begravelse & 1909 & Opus 9 & 14 \\
Bjørnstjerne Bjørnson i slåbrok & $1908-1909$ & Opus 2 & 6 \\
Boken & 1922 & Opus 86 & 174 \\
Borgermester Hagbart Berner I & 1918 & Opus 4 & 87 \\
Borgermester Hagbart Berner II & 1918 & Opus 5 & 88 \\
Bruene & 1920 & Opus 59 & 148 \\
Bygen & 1910 & Opus 16 & 20 \\
Båter under Lysakerbrua & $1908-1909$ & & 2 \\
Da rant solen & 1909 & Opus 11 & 13 \\
Dagfin I & $1918 ?$ & Opus 72 & 82 \\
Dagfin II & 1920 & Opus 44 & 133 \\
Dagfin III & $1935-1937 ?$ & & 245 \\
Dagfin leser avisen & $1919 ?$ & Opus 82 & 127 \\
Dagfin og Beth I & 1918 & Opus 10 & 93 \\
Dagfin og Beth II & 1918 & Opus 12 & 95 \\
Dame med hatt og pels & $1935-1937 ?$ & Opus 147 & 238 \\
Dans & 1920 & Opus 56 & 145
\end{tabular}




\begin{tabular}{|c|c|c|c|}
\hline Tittel & Datering & EW & Katalognummer \\
\hline Danserinne & 1920 & Opus 42 & 130 \\
\hline De to som danser & 1920 & Opus 54 & 143 \\
\hline De tre som valser & 1920 & Opus 55 & 144 \\
\hline Den engelske flåte & 1908-1909 & Opus 7 & 5 \\
\hline Den hvite dame & 1929 & Opus 102 & 197 \\
\hline Djupvassfossen & 1934 & Opus 124 & 223 \\
\hline Dr. med. Borchgrevink & 1918 & Opus 30 & 114 \\
\hline Ellef maler & 1916 & Opus 68 & 77 \\
\hline En alvorlig samtale & 1922 & Opus 87 & 175 \\
\hline En prat & 1920 & Opus 57 & 146 \\
\hline En røyk & 1921 & Opus 68 & 157 \\
\hline Eplekvist & 1921 & Opus 81 & 168 \\
\hline Eskimohunden Balto & 1910 & Opus 14 & 18 \\
\hline Eva Nansen & $1935 ?$ & & 232 \\
\hline Fabrikkpipen & 1917 & Opus 1 & 78 \\
\hline Falketind I & 1931 & & 214 \\
\hline Falketind II & 1931 & Opus 117 & 215 \\
\hline Falketind III & 1935 & Opus 125 & 227 \\
\hline Fanny Elstad & $1935 ?$ & & 231 \\
\hline Fjord bak bjørkene & 1920 & Opus 41 & 129 \\
\hline Fjord og fugler & 1910 & Opus 33b & 17 \\
\hline Fjordhesten & 1933 & Opus 122 & 220 \\
\hline Fjording i tjor & 1928 & Opus 100c & 192 \\
\hline Flette håret & $1935-1937 ?$ & Opus 144 & 237 \\
\hline Folungen I & 1918 & Opus 18 & 102 \\
\hline Folungen II & 1929 & Opus 108 & 201 \\
\hline Fra Kabelvåg & 1914 & Opus 56 & 61 \\
\hline Fra Tyriholmen & 1930 & & 212 \\
\hline Fra Vangsmjøsa I & 1930 & Opus 113 & 208 \\
\hline Fra Vangsmjøsa II & 1930 & Opus 113b & 209 \\
\hline Fra Vågå & 1934 & Opus 128 & 224 \\
\hline Frederik Collett I & 1913 & Opus 46 & 51 \\
\hline Frederik Collett II & 1913 & Opus 47 & 52 \\
\hline Fridtjof Nansen I & 1920 & Opus 64 & 153 \\
\hline Fridtjof Nansen II & 1924 & Opus 91 & 180 \\
\hline
\end{tabular}




\begin{tabular}{|c|c|c|c|}
\hline Tittel & Datering & EW & Katalognummer \\
\hline Fru Emma Stang I & 1915 & Opus 62 & 70 \\
\hline Fru Emma Stang II & 1915 & & 71 \\
\hline Fru Emma Stang III & 1915 & & 72 \\
\hline Fru Emma Stang IV & 1916 & Opus 66 & 76 \\
\hline Fru Ingeborg Fearnley & 1915 & Opus 63 & 73 \\
\hline Fru Poulsson & 1918 & Opus 34 & 118 \\
\hline Fru Ragnhild Heiberg & 1916 & Opus 64 & 74 \\
\hline Fru Østby & 1925 & Opus 93 & 182 \\
\hline Furuene på Hindsæter & 1913 & Opus 44 & 50 \\
\hline Furuene ved fjorden & 1912 & Opus 33 & 31 \\
\hline Furutrærne & 1910 & Opus 15 & 19 \\
\hline Første fors $\varnothing k$ & 1904 & & 1 \\
\hline Gamle bjørketrær på en haug & 1921 & Opus 79 & 170 \\
\hline Gardisten & 1929 & Opus 104 & 199 \\
\hline Gate i Kongsberg & 1918 & Opus 19 & 103 \\
\hline Gate i Kongsberg med asketrær & 1918 & Opus 22 & 106 \\
\hline Gjendetrollet & 1912 & Opus 24 & 28 \\
\hline Glomma fra Kongsvinger festning & 1929 & Opus 103 & 198 \\
\hline Gran og furu med snø på & 1912 & Opus 31 & 32 \\
\hline Granen som bøyer seg for vinden & 1918 & Opus 8 & 91 \\
\hline Gutt med skinnlue & 1918 & Opus 6 & 89 \\
\hline Gutteflokk & 1919 & Opus 38 & 123 \\
\hline Gutten som hugger hodene av trollet I & 1929 & Opus 106 & 206 \\
\hline Gutten som hugger hodene av trollet II & 1930 & Opus 107 & 207 \\
\hline Gutter på ski I & 1912 & Opus 45 & 33 \\
\hline Gutter på ski II & $1912 ?$ & & 34 \\
\hline Gutter slår ball & $1918 ?$ & & 86 \\
\hline Gutt som binder på seg skiene & 1912 & Opus 27 & 35 \\
\hline Halvmånen & 1913 & Opus 35 & 41 \\
\hline Hans E. Kinck I & 1914 & Opus 53 & 58 \\
\hline Hans E. Kinck II & 1920 & Opus 60 & 149 \\
\hline Hans E. Kinck III & 1920 & Opus 61 & 150 \\
\hline Hans Mustad I & 1915 & Opus 57 & 62 \\
\hline Hans Mustad II & 1915 & Opus $67 a$ & 63 \\
\hline Hans Mustad III & 1915 & Opus 67b & 64 \\
\hline
\end{tabular}




\begin{tabular}{|c|c|c|c|}
\hline Tittel & Datering & EW & Katalognummer \\
\hline Hans Mustad IV & 1915 & Opus 67c & 65 \\
\hline Hans Aall & 1920 & Opus 46 & 134 \\
\hline Heidalen med elva & 1913 & Opus 38 & 44 \\
\hline Helge Brinchmann & 1918 & Opus 21 & 105 \\
\hline Henrik Sørensen og Jean Heiberg I & 1920 & Opus 48 & 136 \\
\hline Henrik Sørensen og Jean Heiberg II & 1920 & Opus 49 & 137 \\
\hline Hest med føll på fjellet & 1929 & Opus 109 & 202 \\
\hline Hest og føll & 1921 & Opus 80 & 171 \\
\hline Hester på havn & 1918 & Opus 17 & 101 \\
\hline Hoppe tau I & 1918 & Opus 15 & 99 \\
\hline Hoppe tau II & 1918 & Opus 16 & 100 \\
\hline Huldra I & 1924 & Opus 90 & 179 \\
\hline Huldra II & 1933 & Opus 119 & 217 \\
\hline Huldra III & 1933 & Opus 120 & 218 \\
\hline Hund og katt & 1918 & Opus 31 & 115 \\
\hline Hunelven & 1915 & Opus 58 & 66 \\
\hline Høye furuer & 1918 & Opus 35 & 119 \\
\hline Høyfjell & 1908-1909 & Opus 1 & 4 \\
\hline Høykjøring i fjellbygda & 1931 & Opus 118 & 216 \\
\hline Høylasset oppover låvebrua & 1933 & Opus 121 & 219 \\
\hline Hånd i hånd & 1913 & Opus 30 & 38 \\
\hline Inga & 1918 & Opus 9 & 92 \\
\hline Jens Erik, Tone og Bebe med ringbanen & $1920 ?$ & Opus 83 & 128 \\
\hline Jens Werenskiold Berg & 1934 & Opus 129 & 225 \\
\hline Jørgen og Vir & 1920 & Opus 65 & 154 \\
\hline Kaptein Otto Sverderup & 1921 & Opus 78 & 167 \\
\hline Kari & 1921 & Opus 77 & 166 \\
\hline Katten & 1929 & Opus 105 & 200 \\
\hline Kjelken & $1918 ?$ & & 85 \\
\hline Kjemme håret & 1928 & Opus 100 & 190 \\
\hline Konsul Heiberg & 1918 & Opus 45 & 120 \\
\hline Kua på sætra & 1913 & Opus 42 & 48 \\
\hline Kuene & 1935 & Opus 130 & 226 \\
\hline Kullsjau & 1909 & Opus 8 & 11 \\
\hline Kusiner & 1920 & Opus 63 & 152 \\
\hline
\end{tabular}




\begin{tabular}{|c|c|c|c|}
\hline Tittel & Datering & EW & Katalognummer \\
\hline Kvinner & $1918 ?$ & Opus 70a & 81 \\
\hline Landskap fra Kviteseid I & 1925 & Opus 94 & 184 \\
\hline Landskap fra Kviteseid II & 1925 & Opus 95 & 185 \\
\hline Landskap fra Kviteseid III & 1925 & Opus 96 & 186 \\
\hline Landskap fra Rauland I & 1928 & Opus 10ob & 191 \\
\hline Landskap fra Rauland II & 1928 & Opus 10od & 193 \\
\hline Lensekara I & 1937 & Opus 131 & 246 \\
\hline Lensekara II & 1938 & Opus 132 & 247 \\
\hline Lillegutt & 1918 & Opus 11 & 94 \\
\hline Lindetrær og graner & 1920 & Opus 53 & 142 \\
\hline Liten gutt i gyngestol & 1919 & Opus 39 & 124 \\
\hline Liten gutt med skyggelue & $1935-1937 ?$ & & 240 \\
\hline Liten pike & 1935-1937? & & 242 \\
\hline Lysakerbrua & 1918 & Opus 24 & 108 \\
\hline Lysakerbrua, vinter & 1908-1909 & Opus 3 & 7 \\
\hline Lysakerelva & 1908-1909 & Opus o & 3 \\
\hline Lysakerfabrikken I & 1918 & Opus 28 & 112 \\
\hline Lysakerfabrikken II & 1918 & Opus 29 & 113 \\
\hline Lysakerfjorden & 1910 & Opus 13 & 16 \\
\hline Lyse sommer & 1914 & Opus 54 & 59 \\
\hline Løpende troll & 1909 & Opus 10 & 12 \\
\hline Magnus Poulsson & $1935-1937 ?$ & & 241 \\
\hline Mally Lammers & 1935-1937? & Opus 137a & 233 \\
\hline Melkehesten & 1918 & Opus 3 & 80 \\
\hline Mesna & 1913 & Opus 48 & 53 \\
\hline Mor leker fremmed dame & 1920 & Opus 67 & 156 \\
\hline Motgang & 1925 & Opus 92 & 181 \\
\hline Nakne lindetrær & 1918 & Opus 7 & 90 \\
\hline Nansens hus, Polhøgda & 1909 & Opus 5 & 9 \\
\hline Nautgardstind & 1913 & Opus 40 & 46 \\
\hline Nedsnødde smågraner & 1913 & Opus 32 & 39 \\
\hline Nils Berg & 1931 & Opus 116 & 213 \\
\hline Nils Collett Vogt & 1920 & Opus 58 & 147 \\
\hline Nordahl Rolfsen & 1920 & Opus 47 & 135 \\
\hline O. Thommesen & 1935-1937? & & 244 \\
\hline
\end{tabular}




\begin{tabular}{|c|c|c|c|}
\hline Tittel & Datering & EW & Katalognummer \\
\hline Odd Nansen & 1921 & Opus 73 & 162 \\
\hline Olaf Berge I & 1930 & Opus 114 & 210 \\
\hline Olaf Berge II & 1930 & Opus 115 & 211 \\
\hline Opplagte båter ved Lysakerbrua & 1912 & Opus 26 & 30 \\
\hline Oscar Heiberg & 1916 & Opus 65 & 75 \\
\hline Per & 1929 & Opus 112 & 205 \\
\hline Per og Lulla & $1928 ?$ & Opus 112b & 195 \\
\hline Planting & 1918 & Opus 25 & 109 \\
\hline Professor Schiøtz & 1921 & Opus 72 & 161 \\
\hline På verandaen & 1918 & Opus 33 & 117 \\
\hline Ragnar Östberg & 1927 & Opus 99 & 187 \\
\hline Raulandsstranda & 1928 & & 194 \\
\hline Reinsdyr & 1914 & Opus 52 & 57 \\
\hline Revolusjonen & $1921 ?$ & Opus 152b & 169 \\
\hline Saga I & $1918 ?$ & Opus 7ob & 83 \\
\hline Saga II & 1927 & Opus 73 & 183 \\
\hline Schanche som Hamlet & $1921 ?$ & & 158 \\
\hline Schnéevoigt & 1922 & Opus 85 & 173 \\
\hline Schnéevoigt dirigerer & 1922 & Opus 84 & 172 \\
\hline Seilbåten mellom trærne I & $1918 ?$ & & 97 \\
\hline Seilbåten mellom trærne II & 1918 & Opus 14 & 98 \\
\hline Seileren & 1919 & Opus 36 & 121 \\
\hline Setningsbygninga e'kje rekti & $1918 ?$ & & 84 \\
\hline Sigrid og Bebe & 1920 & Opus 52 & 141 \\
\hline Sjoa og Steinfinsbø & 1913 & Opus 37 & 43 \\
\hline Skybanken & 1918 & Opus 32 & 116 \\
\hline Skygger over Flyen & 1913 & Opus 39 & 45 \\
\hline Sløyfen & 1920 & Opus 62 & 151 \\
\hline Småfuru & 1910 & Opus 19 & 23 \\
\hline Smågran og furustammer & 1914 & Opus 51 & 56 \\
\hline Smågutt ved stranda & $1935^{-1937 ?}$ & & 243 \\
\hline Smågutter som fisker & 1910 & Opus 17 & 21 \\
\hline Sophie og Vir & 1920 & Opus 66 & 155 \\
\hline Solbergløpet & 1914 & Opus 50 & 55 \\
\hline Som en blomst & 1935 & Opus 126 & 228 \\
\hline
\end{tabular}




\begin{tabular}{|c|c|c|c|}
\hline Tittel & Datering & EW & Katalognummer \\
\hline Sommervind. Oslofjorden & 1929 & Opus 101 & 196 \\
\hline Steinfinsbø & 1913 & Opus 36 & 42 \\
\hline Steinspill & 1918 & Opus 20 & 104 \\
\hline Store tordenskyer & 1921 & Opus 75 & 164 \\
\hline Stormen & 1911 & Opus 21 & 25 \\
\hline Svartdal & 1935-1937? & Opus 139 & 236 \\
\hline Svingen & 1918 & Opus 13 & 96 \\
\hline Syv søstre & 1914 & Opus 55 & 60 \\
\hline Tank & 1914 & Opus 49 & 54 \\
\hline Thorleif Schjelderup & $1935 ?$ & Opus 135 & 230 \\
\hline Thorvald Erichsen I & 1920 & Opus 50 & 138 \\
\hline Thorvald Erichsen II & 1920 & Opus 70 & 139 \\
\hline Thorvald Erichsen III & 1920 & Opus 145 & 140 \\
\hline Thorvald Heiberg & 1915 & Opus 60 & 68 \\
\hline Thorvald Lammers I & $1935-1937 ?$ & & 234 \\
\hline Thorvald Lammers II & 1935-1937? & & 235 \\
\hline Tilsnødd skog & 1911 & Opus 23 & 27 \\
\hline To fabrikkpiper & 1919 & Opus 37 & 122 \\
\hline To gutter & 1909 & Opus 6 & 10 \\
\hline To gutter som skriver i bakken & 1912 & Opus 25 & 29 \\
\hline To gutter ved kakkelovnen & 1913 & Opus 34 & 40 \\
\hline To på en stol & 1921 & Opus 69 & 159 \\
\hline Tone og Bebe & 1922 & Opus 88 & 176 \\
\hline Tordenskyer & 1921 & Opus 76 & 165 \\
\hline Trappen & 1922 & Opus 89 & 178 \\
\hline Tre prinsesser & 1910 & Opus 12 & 15 \\
\hline Trollkjerringa og de tre prinsessene & 1911 & Opus 20 & 24 \\
\hline Trollpakk I & 1913 & Opus 28 & 36 \\
\hline Trollpakk II & 1913 & Opus 29 & 37 \\
\hline Tulipaner & 1918 & Opus 23 & 107 \\
\hline Tømmerlasset & 1928 & Opus 98 & 189 \\
\hline Unghest med sele på & 1915 & Opus 59 & 67 \\
\hline Unghesten & 1920 & Opus 43 & 132 \\
\hline Ut på ski & 1921 & Opus 74 & 163 \\
\hline Vaske beina & 1935-1937? & Opus 148 & 239 \\
\hline
\end{tabular}




\begin{tabular}{lccc}
\hline Tittel & Datering & EW & Katalognummer \\
\hline Venninner & 1909 & Opus 4 & 8 \\
Vi er på ball & 1920 & Opus 69 & 131 \\
Vinter & 1918 & Opus 27 & 111 \\
Vinter oppi bakken & 1928 & Opus 97 & 188 \\
Vinternatt & 1911 & Opus 22 & 26 \\
Wergeland på Veslebrunen I & 1918 & Opus 26 & 110 \\
Wergeland på Veslebrunen II & 1934 & Opus 123 & 221 \\
Wergeland på Veslebrunen III & 1934 & & 222 \\
Werner Werenskiold & 1919 & Opus 51 & 125 \\
Ørtebekken & 1929 & Opus 110 & 203 \\
\hline
\end{tabular}

